\title{
WOMEN IN XHOSA DRAMA: DRAMATIC AND CULTURAL PERSPECTIVES
}

\section{BY}

\section{PRISCILLA NOMSA SATYO}

Dissertation presented for the Degree of Doctor of Literature at the University of Stellenbosch.

Promoter: $\quad$ Prof JA du Plessis 


\section{DECLARATION}

I, the undersigned, hereby declare that the work contained in this dissertation is my own original work and that I have not previously in its entirety or in part submitted it at any University for a degree. 


\section{ABSTRACT}

This study aims at highlighting a crucial aspect of Xhosa drama: The portrayal of the role women have been forced culturally to assume in society. A selection of Xhosa plays from three periods (1958 - 1965; 1974 - 1982; and 1988 - 1997) is examined. In the process of the study, the analysis and the interpretation of these dramas as well as the depiction of women characters is examined.

Authors of the ten dramas under study advocate change through the powerful forces of gender stereotypes and culture distortions.

The attributes that the authors commonly ascribe to women characters are passivity, irrationality, compliancy and incorrigibility. An examination of the reasons behind this proliferation of these female stereotypes and the lack of realistic women characters is undertaken.

The study posits reasons why particular stereotypes appear in the works of several authors over a period of time. The women characters are products of social conditioning, that is, ideals or counter-ideals of the prevailing values of the authors' culture. They are a symbolic fulfillment of the writers' needs.

The broad cultural perspectives of the authors also shape the texts they produce. These dramas treat issues and themes, which become central to the formal and structural ordering of the drama. Such themes have an impact at times on form and structure. In each case the ideology of the class represented by authors under study is indeed reflected in the text, to its detriment.

The dominating themes in the ten dramas are forced marriages and women abuse. The authors are so preoccupied with injustices against women that they distort certain cultural aspects by, for example, exaggeration. Women are constantly depicted as victims, while there are no indications in the authors' depictions of women that perceptions of their cultural role and status are in reality undergoing changes. 
The thesis is arranged as follows:

Chapter 1 introduces the aim, the scope, the theories and the methods of the study.

Chapter 2 deals with the development of plot within episodes in the dramas of the first literary period (1958 - 1965). These episodes depict the different phases of the dramas. A critical evaluation of the dramas by motivating their positive and negative aspects is undertaken.

Chapter 3 deals with the development of plot within episodes in the dramas of the second literary period (1974 - 1982). As in the first literary period, a critical evaluation of the dramas by motivating their positive and negative aspects is examined.

Chapter 4 deals with the development of plot within episodes in the dramas of the third literary period (1988 - 1997). A critical evaluation of the dramas by motivating their good and bad points is undertaken.

Chapter 5 deals with woman as character in Xhosa dramas under study. A detailed analysis of the main woman character in each drama is undertaken. Furthermore, a critical summary of how the woman has been portrayed in the dramas is presented.

Chapter 6 presents depiction of Xhosa culture in the Xhosa dramas. From each drama, certain selected aspects of culture are explored and an investigation of the portrayal of these aspects is undertaken.

Chapter 7 summarizes the findings of the study. 


\section{OPSOMMING}

Die doelstelling van hierdie studie is om ' $n$ kern aspek van Xhosa drama te belig: die rolle wat vroue kultureel gedwing is om te vervul in die gemeenskap. 'n Seleksie Xhosa dramas vanuit drie tydperke (1958 - 1965; 1974 - 1982; en 1988 - 1997) word ondersoek. In die loop van die studie, ontleding en interpretasie van hierdie dramas word die uitbeelding van vroue karakters ook ondersoek.

Die skrywers van die tien dramas wat bestudeer word, betoog vir verandering deur middel van die sterk kragte van stereopites en kultureelverwronge voorstellings. Die eienskappe wat die skrywers algemeen toeskryf aan vroue karakters is passiwiteit, irrasionele optrede, gehoorsaamheid en deugsaamheid. 'n Ondersoek na die redes vir die proliferasie van hierdie vroulike stereotipes en die tekortkoming aan realistiese vroue karakters in Xhosa dramas word uitgevoer in die studie.

Die studie voer redes aan waarom bepaalde stereotipes in die werk van verskeie skrywers oor 'n tydperk verskyn: hulle vrouekarakters is die produk van sosiale kondisionering, dit wil sêm ideale of teen-ideale van die heersende waardes van die skrywer se kulturele agtergrond en 'n simboliese vervulling van die skrywer se behoeftes.

Die algemene kulturele perspektiewe van die skrywers beïnvloed en vorm ook die tekste wat hulle lewer. Hierdie dramas behandel naamlik vraagstukke tematies wat sentraal ook bepalend is ten opsigte van die vorm en struktuur van die drama. Sodanige temas het gevolglik in bepaalde gevalle ' $n$ invloed op die vorm en struktuur van die drama. Voorts word die ideologie van die klas verteenwoordig deur die skrywers in elke geval gereflekteer en die teks tot bepaalde nadele daarvan.

Die prominente temas in die tien dramas is gedwonge huwelike en vrouemishandeling. Die skrywers is so gepre-okkupeer met die ongeregtighede teenoor vroue dat hulle bepaalde kulturele aspekte verwring deur, byvoorbeeld, buitensporige voorstellings. Vroue word voortdurend voorgestel as slagoffers, terwyl daar feitlik geen aanduidings is in die skrywer se voorstelling van vroue, dat persepsies oor hulle kulturele rol en status inderwaarheid besig is om veranderinge te ondergaan. 
Die proefskrif is soos volg gestruktureer:

Hoofstuk 1 gee die doelstellings, omvang, teorieë en metodes wat in die studie gevolg word.

Hoofstuk 2 behandel die ontwikkeling van intrige binne verskillende episodes in die dramas van die eerste literêre periode (1958 - 1965). Hierdie episodes gee ' $n$ uitbeelding van die verskillende fases van die dramas wat in die studie ondersoek word. 'n Kritiese evaluering word van die dramas gedoen deur die positiewe en negatiewe aspekte daarvan te motiveer.

Hoofstuk 3 behandel die ontwikkeling van intrige binne die episodes van die dramas van die tweede literêre periode (1974 - 1982). Soos vir die eerste literêre periode, word 'n kritiese evaluering gedoen van die dramas deur onder andere die positiewe en negatiewe literêre aspekte daarvan te motiveer.

Hoofstuk 4 ondersoek die ontwikkeling van die intrige binne die episodes in die dramas van die derde literêre periode (1988 - 1997). Die kritiese evaluering van hierdie dramas sluit, soos vir die vorige periodes, 'n gemotiveerde beskouing in van die positiewe en negatiewe aspekte.

Hoofstuk 5 ondersoek die vrou as karakter in die Xhosa dramas wat bestudeer word. 'n Gedetaileerde analise van die hoof-vroue karakters in elke drama word gedoen. Daarna word 'n kritiese oorsig aangebied van hoe die vrou voorgestel word in die dramas wat bestudeer is.

Hoofstuk 6 bied ' $n$ uitbeelding van Xhosa kultuur in die dramas wat ondersoek is. Bepaalde aspekte van kultuur word vir elke drama ondersoek en die uitbeelding van hierdie kultuur aspekte word behandel.

Hoofstuk 7 bied ' $n$ opsomming van die belangrikste bevindinge van die studie. 
This study is dedicated with utmost gratitude to my late father, Tamsanqa "Bhabhi". 


\section{ACKNOWLEDGEMENTS}

I wish to convey my sincere appreciation to:

Professor JA du Plessis, my promotor, for his commitment to this work. As a teacher, parent, scholar and educator, he has guided and inspired me through this project.

I owe a lot of gratitude to Professor Marianna Visser for her usual warmth, unwavering support and sisterhood.

> Words cannot fully express the gratitude I owe my friend and colleague Professor Nogwaja Zulu for his unalloyed support and persistent encouragement. He never wavers in his belief that I have something worthwhile to contribute.

$>$ I am grateful to my colleagues in the Department of African Languages at the University of Stellenbosch for their willingness to help me in various ways.

> The financial assistance of National Research Foundation (NRF) towards this research is hereby acknowledged. Opinions expressed and conclusions arrived at, are those of the author and are not necessarily to be attributed to the National Research Foundation.

> I also want to express my heartfelt gratitude to Rose Richards for her skilled assistance with the editing of this study despite her tight programme of work.

I am grateful to Karin in whom I found not only an excellent typist but also a warm and wonderful person.

$>$ I am proud of and grateful to the entire Satyo and Mgabadeli family, for always being there for me particularly my late father Tamsanqa, my mother, Nolusapho, bhuti Sizwe, Malihambe and Nontsasa. I thank them for being a pillar of strength and teaching me patience.

$>$ My sister Nontsasa and my brother-in-law, Dudu deserve a special mention. Their tender loving care, patience and dedication to me, and my daughter Lindelwa have made it much easier for me to write and finish this thesis.

> To my wonderful niece and nephews, Sikelelwa, Ayanda, Sivuyile and Siyabulela I say a big thank you. You are so good and precious. 


\section{TABLE OF CONTENTS}

Page

ABSTRACT

\section{CHAPTER 1: INTRODUCTION}

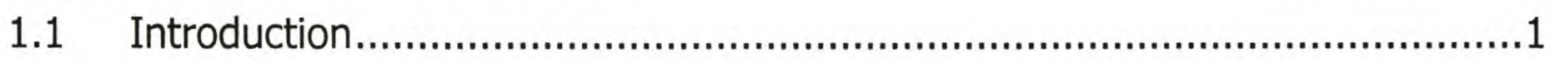

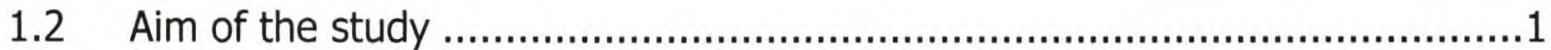

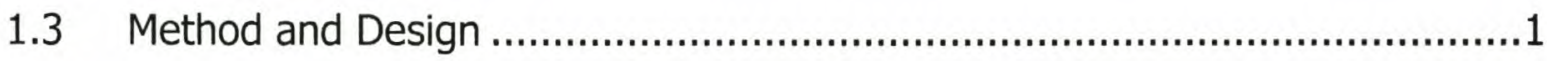

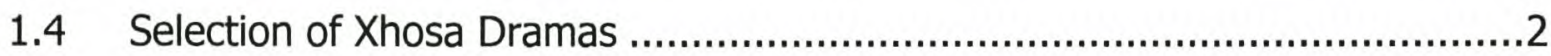

1.5 An Overview of Theories of Culture ............................................................

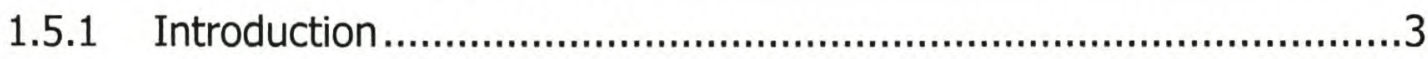

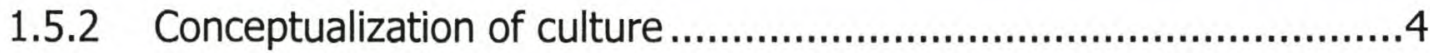

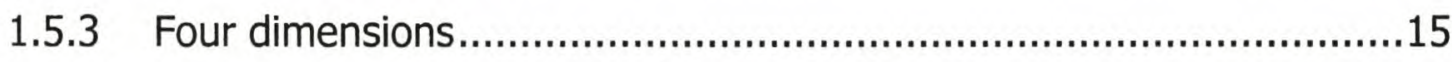

1.5.3.1 On defining Power Distance ...........................................16

1.5.3.2 Uncertainty Avoidance .................................................18

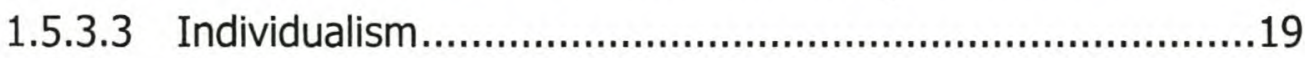

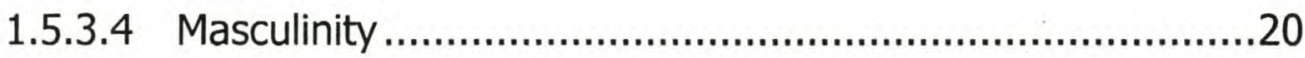

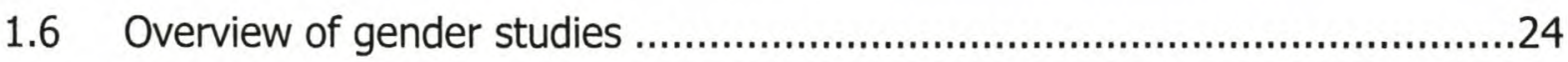

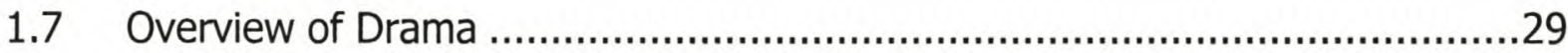

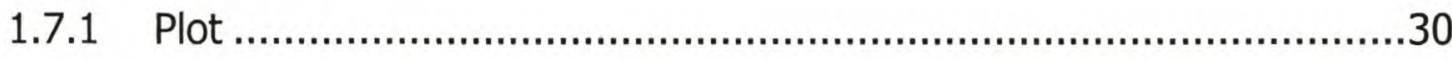

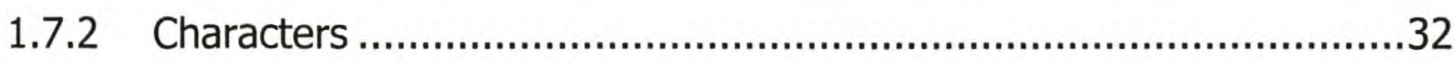

1.7.2.1 Types of Characters......................................................33

1.7.2.2 Character, dialogue and action ........................................35

1.7.2.3 Conflict ..........................................................................36

\section{CHAPTER 2: PLOT STRUCTURE IN THE FIRST LITERARY PERIOD (1958-1965)}

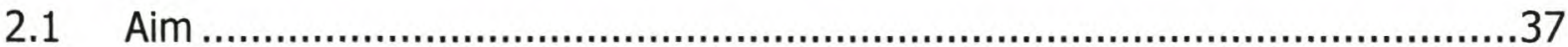

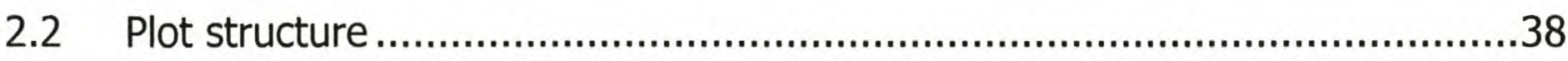

2.2.1 Buzani kubawo (W.K. Tamsanqa, 1958).......................................38

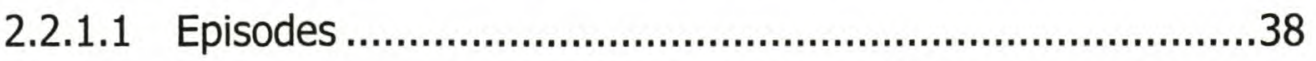


2.2.1.2 Analysis of the plot structure ........................................48

2.2.2 UDike noCikizwa (A.M. Mmango, 1963) .......................................53

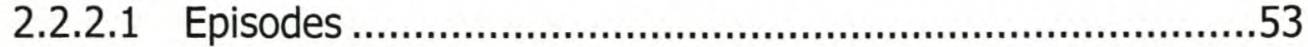

2.2.2.2 Analysis of the plot structure ..........................................68

2.2.3 Inene nasi isibhozo (A. Mtingane, 1965) ......................................72

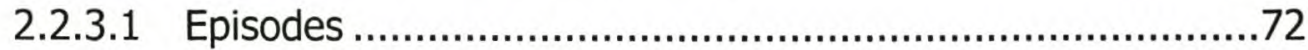

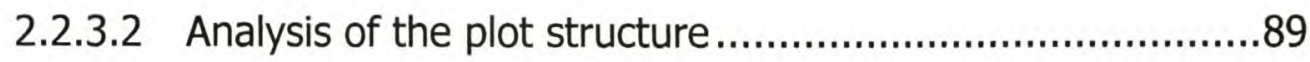

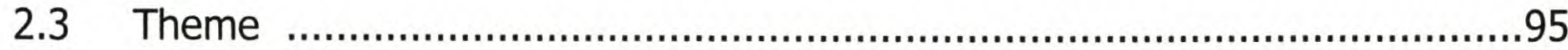

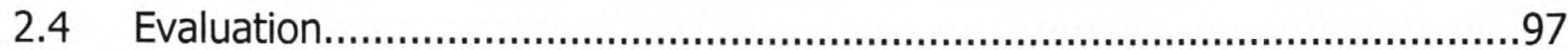

\section{CHAPTER 3: PLOT STRUCTURE IN THE SECOND LITERARY PERIOD (1973-1982)}

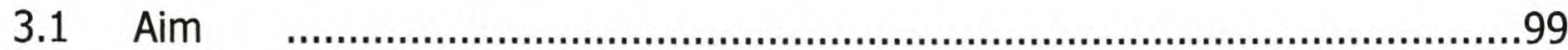

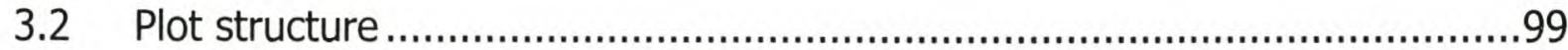

3.2.1 Ubusuku obungenanyanga (D.M. Jongilanga, 1973) ......................99

3.2.1.1 Episodes ....................................................................99

3.2.1.2 Analysis of the plot structure ........................................113

3.2.2 Amaza (Z.S. Qangule, 1974) ....................................................116

3.2.2.1 Episodes .....................................................................116

3.2.2.2 Analysis of the plot structure ......................................127

3.2.3 UFeziwe okanye inkohlakalo (D.T. Mtywaku, 1982) .........................129

3.2.3.1 Episodes .....................................................................129

3.2.3.2 Analysis of the plot structure .........................................140

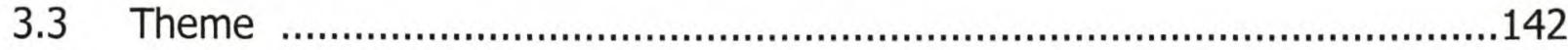

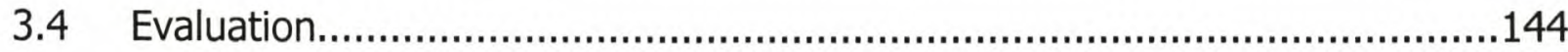

\section{CHAPTER 4: PLOT STRUCTURE IN THE THIRD LITERARY PERIOD (1988-1997)}

4.1 Aim

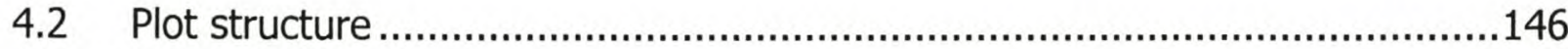

4.2.1 Emgxobhozweni (B.B. Mkonto, 1988) …....................................146

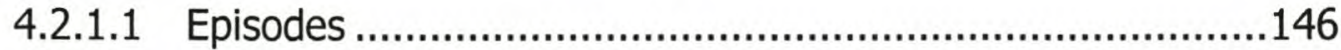

4.2.1.2 Analysis of the plot structure ........................................155

4.2.2 Iintombi zinecebo (R. Mcimeli, 1992) ............................................159

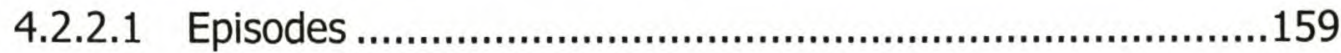


4.2.2.2 Analysis of the plot structure .......................................182

4.2.3 Iinkunzi ezimbini (H. Mothlabane, 1994) .....................................185

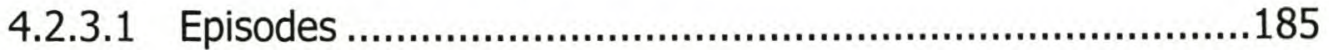

4.2.3.2 Analysis of the plot structure .......................................195

4.2.4 Yeha-a mfazi obulala indoda (L.L. Ngewu, 1997) ............................197

4.2.4.1 Episodes ......................................................................197

4.2.4.2 Analysis of the plot structure ......................................211

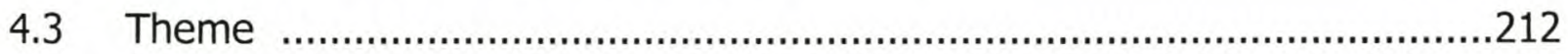

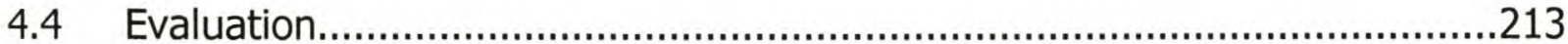

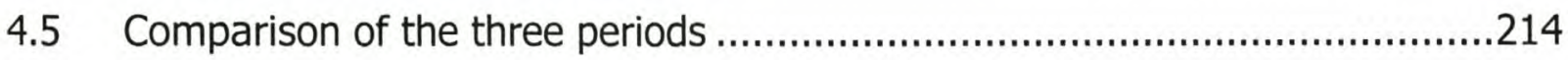

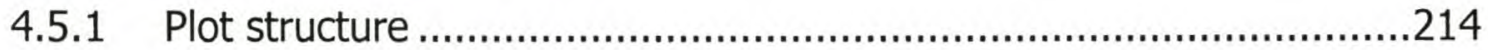

4.5.2 Theme

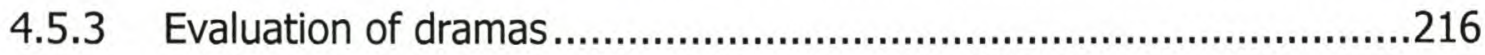

\section{CHAPTER 5: THE WOMAN AS A CHARACTER IN THE XHOSA DRAMAS}

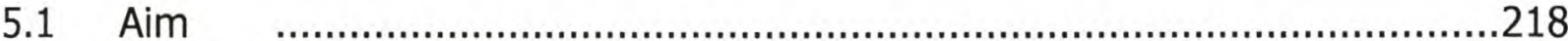

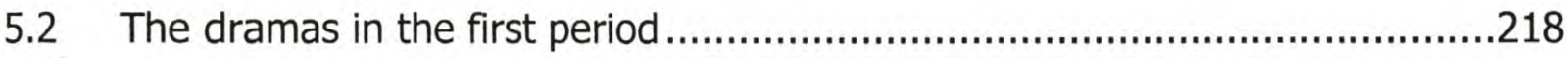

5.2.1 NomaMpondomise (in W.K. Tamsanqa's Buzani Kubawo).................218

5.2.2 Cikizwa (in A.M. Mmango's uDike noCikizwa) ................................221

5.2.3 MaSukude (in A. Mtingane's Inene nasi isibhozo) ...........................224

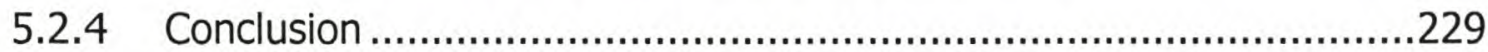

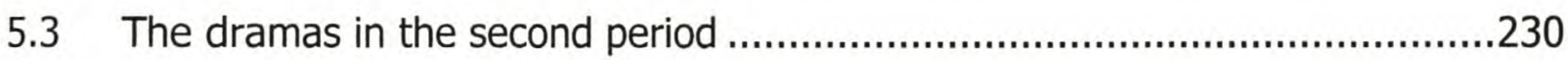

5.3.1 Novayithi (in D.M. Jongilanga's Ubusuku obungenanyanga) .............230

5.3.2 Namhla (in Z.S. Qangule's Amaza)...............................................233

5.3.3 Feziwe (in Mtywaku's UFeziwe okanye inkohlakalo) .........................235

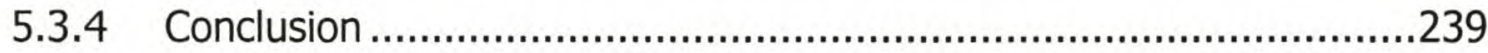

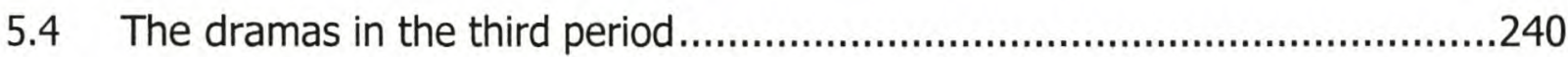

5.4.1 Nolasti (in Mothlabane's Iinkunzi ezimbini) ...................................240

5.4.2 Nozinto (in Ngewu's Yeha-a mfazi obulala indoda)...........................245

5.4.3 No-ankile (in Mkonto's Emgxobhozweni) .......................................257

5.4.4 Nomhle (in Mcimeli's Iintombi zinecebo) .......................................258

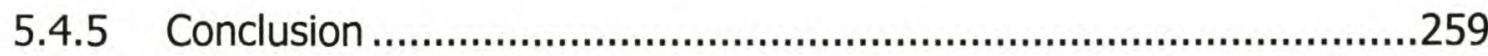

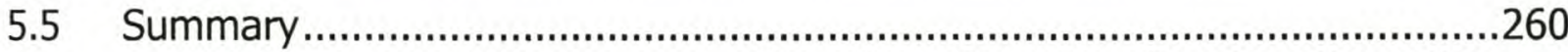


5.5.1 Conclusion with regard to the three periods

5.5.2 Conclusion with regard to the two themes of abuse and forced

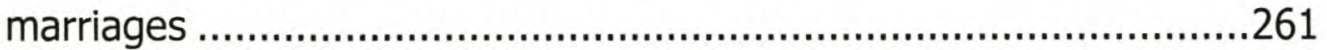

5.5.2.1 Dramas with forced marriages as a theme ........................261

5.5.2.2 Dramas with women abuse as a theme............................265

5.5.3 Conclusion with regard to the portrayal of women in the Xhosa dramas

5.5.4 A comparison of the portrayal of women in the drama and the Universal view of women from the viewpoint of gender studies 268

\section{CHAPTER 6: THE DEPICTION OF CULTURE IN THE XHOSA DRAMA}

6.1 Aim

6.2 Marriage.

272

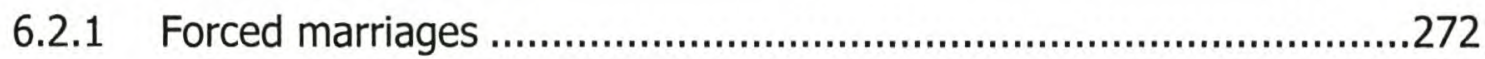

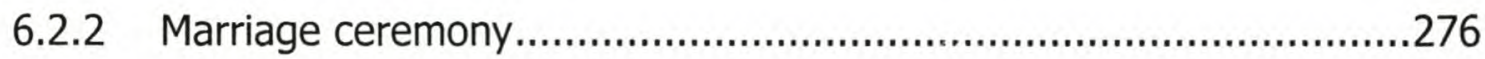

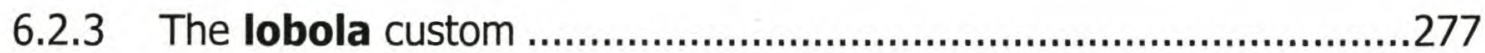

6.2.4 The rules of ukuthwala in Xhosa culture ....................................277

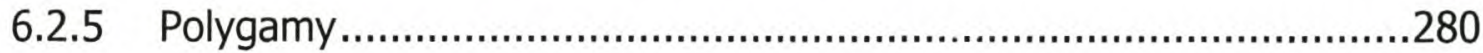

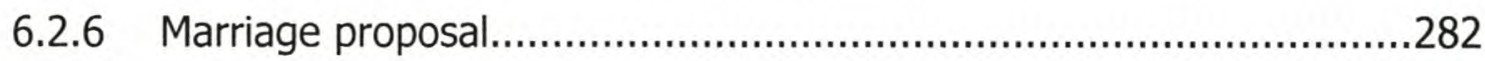

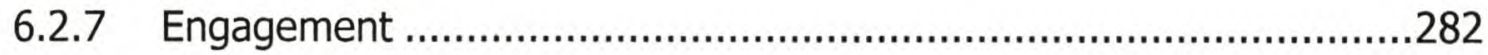

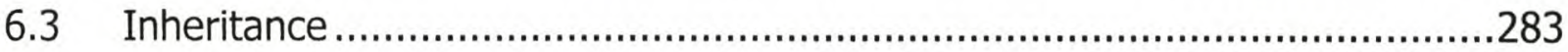

6.3.1 The heir being bound by tradition to follow his society's customs .....283

6.3.2 Control of the widow's homestead................................................284

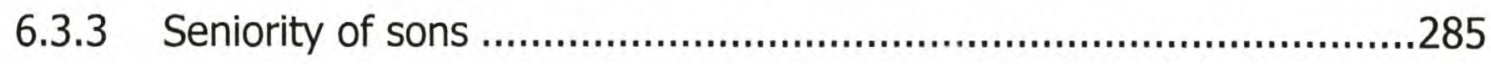

6.3.3.1 Mother's position when the son marries ...........................287

6.3.3.2 Mfolo's and No-ayini's speeches about women rights .........288

6.3.4 The ukungena custom ............................................................289

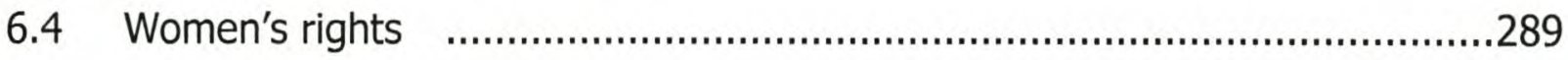

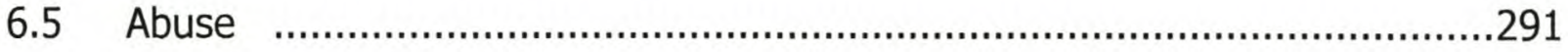

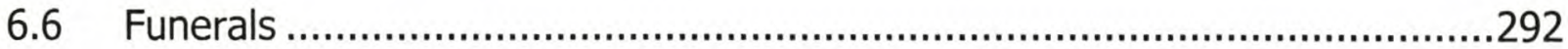

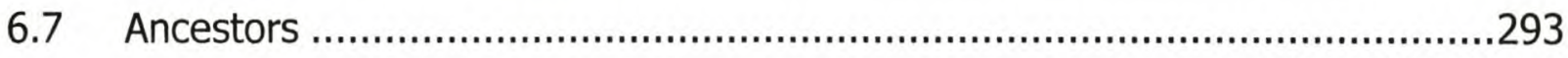

6.8 Illegitimate children born to unmarried daughter....................................294

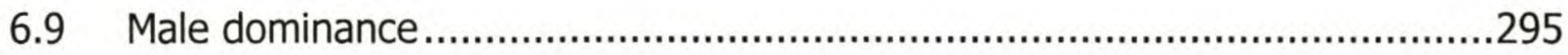




\section{CHAPTER 7: CONCLUSION}

7.1 Aim

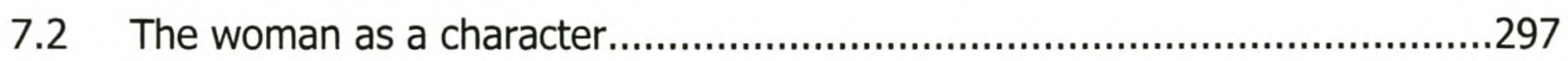

7.2.1 MaSukude in Inene nasi isibhozo ...............................................297

7.2.2 NomaMpondomise in Buzani kubawo ............................................298

7.2.3 Cikizwa in UDike noCikizwa ...........................................................299

7.2.4 Feziwe in UFeziwe okanye inkohlakalo ........................................299

7.2.5 Novayithi in Ubusuku obungenanyanga .......................................300

7.2.6 Namhla in Amaza .............................................................................301

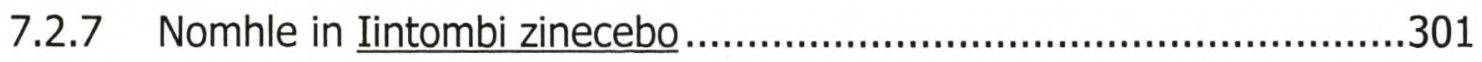

7.2.8 Nozinto in Yeha-a mfazi obulala indoda .......................................302

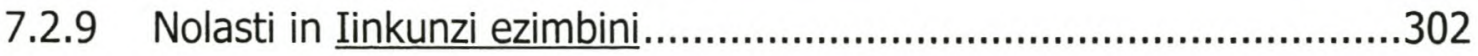

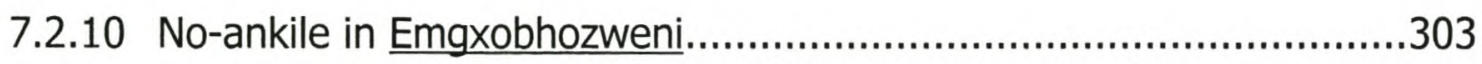

7.3 Portrayal of women in Xhosa drama ...........................................................

7.4 Criticism of women characters ................................................................306

$\begin{array}{ll}\text { BIBLIOGRAPHY } & 308\end{array}$ 


\section{CHAPTER 1}

\section{INTRODUCTION}

\subsection{INTRODUCTION}

This study on Xhosa drama has the following three interrelated goals:

I. To examine theories of culture with the specific aim of exploring aspects of culture in Xhosa drama from the perspectives of these theories.

II. To explore theories of drama and theatre with reference to its impact on Xhosa drama.

III. To investigate the role of women in Xhosa culture and to establish how this role is realized in the depiction of the woman as a character in Xhosa drama.

\subsection{AIM OF THE STUDY}

The aim of this study is to explore the influence of culture in the characterization of women in Xhosa drama. This will of necessity require a synthetic analysis of various dramas as regards common themes and the cultural properties they reflect. The approach to the discussions will lay more emphasis on the establishment of the full range of complexity of women in Xhosa drama in order to determine whether differences can be identified among various dramas, as regards the depiction of women characters and how such possible differences may reflect differences in the cultural role and status of women in society. Through such a comparison, hopefully, it can be determined whether the depiction of women in these works has kept pace with the strides women have taken in modern day society. An important aim will thus be to establish whether women in literature are always depicted as victims or whether there are indications in drama depictions of women that perceptions of their cultural role and status are undergoing changes.

\subsection{METHOD AND DESIGN}

As indicated above, the dissertation is concerned with three areas of inquiry. These areas will eventually culminate into the central issue: women in Xhosa culture and drama. 
Various existing views on the role of women in Xhosa culture will be examined with special attention to changes in modern society. These views will then be compared with a depiction of culture in Xhosa drama. For this purpose Xhosa drama will be explored with reference to a comparison between older and more recent works. A comparison will then be given of the role of women as characters in the drama and the role of women in Xhosa culture.

The dissertation will thus have the following organization:

Chapter 1: $\quad$ Purpose and aims of the study.

Review of literature on culture and drama and their relationship as reflected in literature.

Gender studies.

Chapter 2 to 4: $\quad$ The plot structure of Xhosa dramas.

Chapter 5: The woman as a character in Xhosa drama.

Chapter 6: The depiction of culture in Xhosa drama.

Chapter 7: $\quad$ Conclusions and summary of findings on women in Xhosa drama.

\subsection{SELECTION OF XHOSA DRAMAS}

The division of the dramas into literary periods is of immense value to this study, because of the light they can shed in determining whether the depiction of women in these works shows changes or decline because of certain thematic concerns of the playwrights. The choice of these dramas was determined by the following criteria:

(a) Drama should have a value to the society so that is why different authors from various periods are selected for the determination of the influence of certain thematic concerns of their dramas. Drama has the power to re-direct the moral and social lives of the audience. 
(b) In the study of this nature, dramas should be selected according to a long period of time. There should be balance within a long period of time.

(c) Protagonist women characters that play central roles in the dramas and the common way in which they are portrayed as stereotypes by dramatists who delve into moral issues for new changes.

The following ten dramas from the following literary periods will be studied:

(a) $1958-1965$

$\begin{array}{lll}\text { Tamsanqa, W.T. } & 1958 & \text { Buzani kubawo } \\ \text { Mmango, A.M. } & 1963 & \text { UDike noCikizwa } \\ \text { Mtingane, A. } & 1965 & \text { Inene nasi isibhozo }\end{array}$

(b) $1973-1982$

$\begin{array}{lll}\text { Jongilanga, DM. } & 1973 & \text { Ubusuku obungenanyanga } \\ \text { Qangule, Z.S } & 1974 & \text { Amaza } \\ \text { Mtywaku, D.T. } & 1982 & \text { UFeziwe okanye inkohlakalo }\end{array}$

(c) $1988-1997$

$\begin{array}{lll}\text { Mkonto, B.B. } & 1988 & \text { Emgxobhozweni } \\ \text { Mcimeli, R.F. } & 1992 & \text { lintombi zinecebo } \\ \text { Mothlabane, H. } & 1994 & \text { linkunzi ezimbini } \\ \text { Ngewu, L } & 1997 & \text { Yeha-a mfazi obulala indoda }\end{array}$

\subsection{AN OVERVIEW OF THEORIES OF CULTURE}

\subsubsection{Introduction}

Issues in the field of culture have always been contentious, producing contradictory arguments and counter-arguments with regards to the conceptualization of culture. Thinking about culture requires some considerable re-orientation in relation to wellestablished notions of what culture is. First and foremost, one needs to rethink what the main focus of a theory of culture is. Perhaps the best initial way to consider the overall set of concerns involved in culture is to apply an ethnographic approach to our current 
understanding of culture, which will be assumed in this study. It would perhaps be appropriate at this point to explore the conceptualization of culture.

\subsubsection{Conceptualization of culture}

Ayisi (1992:1) explains that since man first inhabited this planet, it has been one long struggle for survival between himself and nature. He believes that man has had to live and also to find his place in the universe. Furthermore, he elaborates, "in the process man has left behind traces of his achievements at various levels of his development, and the cumulative knowledge of his various achievements constitutes what we refer to as culture."

The cultural theorist Williams (1976:100) defines culture as one of the four or five key concepts in modern social knowledge. The term culture, he suggests, was originally associated with the idea of the tending or cultivation of crops and animals as, for example, in agriculture from which we derive one of its central modern meanings: "Culture as the process of human development."

Williams (1976:111) further maintains that "culture" came to be associated with "the specific and variable cultures of different nations and peoples", under the influence of the German writer, Herder, as well as the Romantic movement and theories of nationalism. This means that culture described the way of life of particular groups, peoples, nations or periods. According to Williams, it is the meaning, which we still find active when the word "culture" is used to refer to the particular and distinctive "way of life" of a specific social group or period.

Van der Vijver et al (1990:19) point out that conceptualization of culture differs widely. They raise a very piquant issue by declaring that definitions of culture are strikingly different from each other. It is this lack of agreement in defining culture, they say, that creates a problem for cultural scientists. They quote Goudsblom (1960) who avers that culture is too comprehensive a concept to be forced into a definition that will be acceptable to everyone. It is evident therefore that in discussing culture it is necessary to give a broad overview of what culture is generally. Goodman (1993:24) supports this when he avers: 
Essential to a real understanding of man and society is the concept of culture and it points directly to the key difference between man and other animals.

He further maintains that human behaviour is primarily regulated by culture rather than by instinct. Culture channels the way in which basic biological or psychological needs are satisfied.

The above definitions, therefore, spell out that man has to struggle for survival and also reconcile himself with nature.

Van der Vijver et al (1990:19) suggest a certain heuristic approach in their attempt to compose "the best" definition of culture. This approach, they maintain, could involve a synthesized compendium of definitions put forward or the delineation of common premises of various definitions. In order to single out "the best" definition, various criteria such as clarity, comprehensiveness, applicability and fruitfulness could be used.

Kroeber and Kluckhohn (1952), the American anthropologists as quoted by Van der Vijver (1990:20) collected definitions of culture from various sources. The authors of these definitions categorized them into six classes:

(a) Descriptive definitions

Kroeber and Kluckhohn (1952:81) quote Tylor's (1871) definition which runs thus:

Culture $\ldots$ is that complex whole which includes knowledge, belief, art, law, morals, custom, and any other capabilities and habits acquired by man as a member of society.

(b) Historical definitions

They maintain that these definitions emphasize social heritage or tradition. Kroeber and Kluckhohn (1952:89) offer the following definition: 
Culture ... is ... the socially inherited assemblage of practices and beliefs that determines the texture of our lives.

(c) Normative definitions

These definitions emphasize either rule or way, or ideals or values and behaviour. Kroeber and Kluckhohn (1952:95) refer to Wissler's (1929) definition:

The mode of life followed by the community or the tribe is regarded as culture... It includes all standardized social procedure ... A tribal culture ... is the aggregate of standardized beliefs and procedures followed by the tribe.

(d) Psychological definitions

Ford (1939) as quoted by Kroeber and Kluckhohn (1952:106) defines culture as a problem solving device:

Culture is the form of regulations governing human behaviour, provides solutions to societal problems.

(e) Structural definitions

Structural definitions emphasize the patterning or organization of culture. Willey (1929) as quoted by Kroeber and Kluckhohn (1952:125) states that:

A culture is a system of interrelated and interdependent habit patterns of response.

(f) Genetic definitions

Kroeber and Kluckhohn (1952:125) quote Willey (1927) who has this to say about culture:

Culture is that part of the environment which man has himself created and to which he must adjust himself. 
It is evident therefore from the above definitions that culture is probably the broadest concept of all those used in the historical social sciences. Featherstone (1990:31) recommends that:

Culture embraces a very large range of connotations, and thereby it is the cause perhaps of the most difficulty.

He further declares:

... all persons share some traits with all others, all persons also share other traits with only some others, and all persons have still other traits which they share with no one else.

According to Featherstone (1990:31) each person may be described in three ways:

i. the universal characteristics of the species

ii. the sets of characteristics that define that person as a member of a series of groups iii. that person's idiosyncratic characteristics

Gleaning from the above description, one may argue that culture is a way in which groups distinguish themselves from other groups. Featherstone (1950:32) takes this argument one step further by declaring that culture signifies not the totality of the specificity of one group against another. Culture signifies certain characteristics within the group, as opposed to other characteristics within the same group.

Featherstone (1990:32) believes that:

Culture is used to refer to the 'higher' arts as opposed to popular or everyday practice. We use culture to signify that, which is 'superstructural' as opposed to that which is the 'base'. We use culture to signify that which is 'symbolic' as opposed to that which is material.

Fiske, J. (1989:24) indicates that culture is a living active process that can be developed only from within. He does not ascribe to any view that culture can be imposed from 
without or above. According to him, externally produced culture cannot be sold readymade to the masses.

Wheatsheaf (1994:56) reveals that there are three definitions of culture:

There is, first, the ideal, in which culture is a state or process of human perfection, in terms of certain absolute or universal values.

He believes that if such a definition is accepted then the analysis of culture is essentially the discovery and description in lives and works of those values which can be seen to compose a timeless order or to have permanent reference to the universal human condition. Wheatsheaf's second definition of culture is that culture is the body of intellectual and imaginative work in which human thought and experience are recorded in a detailed way. One deduces from this definition that the analysis of culture is the activity of criticism by which the nature of the thought, the details of the language, form and convention in which these are active, are described and valued.

Wheatsheaf (1994:57) further observes that "the analysis of culture is of great importance because it can yield specific evidence about the whole organization within which it was expressed". He maintains that one cannot say that one knows a particular form or period of society until one sees how its art and theory relate to it.

It is worth noting from the above explanation that there are three levels of culture, which need to be distinguished. There appears to be a lived culture of a particular time and place, only fully accessible to those living in that time and place. There is also a culture of a period, which is the recorded culture of every kind from art to the most everyday facts.

Wheatsheaf (1994:60) further reveals that in culture it certainly seems necessary to look for meanings and values, the record of creative human activity, not only in art and intellectual work, but also in institutions and forms of behaviour. This view shows that culture is the medium of life. It is shared by Amuta (1989:79) who avers:

...culture is an essential element of the history of a people. Culture is, perhaps, the product of this history just as the flower is the product of a plant. 
Like history, or because it is history, culture has as its material base the level of the productive forces and the mode of production.

Somehow, Berke (1997:308) do agree with Amuta's views on culture when they declare:

Culture mandates who talks to whom about what and for how long. You were not born knowing a language, how to select "in" clothing, how to spend your time, or the most appropriate ways to show respect. Your culture presented you with a blueprint for how you should live your life and how you should communicate about it.

They further believe that culture is the deposit of knowledge, experience, beliefs, values, attitudes, earnings, religion and material objects acquired by a group of people in the course of generations through individual and group striving. This indicates that people acquire their culture through various channels of communication and express their culture through the same channels.

Raymond Williams as quoted by Storey (1993:20) suggests three broad definitions of culture. He avers:

Culture can be used to refer to a general process of intellectual, spiritual and aesthetic development.

A second definition, which he suggests, is that:

Culture might be to suggest a particular way of life, whether of people, a period or a group.

Williams further maintains that if one speaks of the cultural development of Western Europe, one would have in mind not just intellectual and aesthetic factors, but the development of literacy, holidays, sport and religious festivals. 
Finally, he says about culture:

Culture could be those texts and practices whose principal function is to signify, to produce or to be the occasion for the production of meaning.

Gleaning from the third definition by Williams it is evident that culture is synonymous to what is called "signifying practices" by structuralists and post-structuralists. In culture therefore there are rules and conventions which govern the production of meaning.

According to Davis et al (1991:36) culture encompasses the possession of an individual subject's inner world of a society of individuals conceived as a whole greater than the sum of its parts. They further argues that:

Culture describes the ways in which societies make sense of the common experience of their members, situating "culture" within the domain of "ideas".

Davis et al. (1991:8) share William's views when they say about culture:

Globally, one might say that culture is a signifying system, thanks to which a society or a group understands itself in its relationship with the world.

To support his definitions, Davis quotes Geertz (1973:250):

A culture is a system of symbols by which man confers significance upon his own experience. Symbol systems, man created, shared, conventional ordered, and indeed learned, provide human beings with a meaningful framework for orienting themselves to one another, to the world around them and to themselves.

It is clear therefore from the above definitions that some researchers have adopted an interpretative approach which examines the production and consumption of meanings. Many have stuck to a functionalist approach, questioning the utility of that "thing" called culture. 
Gherardi (1995:12) argues:

For those who adopt a cultural interpretative approach, culture consists of the taken-for-granted and problematic webs of meaning that people produce and deploy when they interact. These systems of meanings are shaped by more general culture and by the institutions and organizations of society at large.

Agger, B (1992:2) describes cultural studies as a hybrid version of cultural interpretation with no vigorous justification. He says that cultural studies address familiar scenes, takenfor-granted knowledge. On a similar note, Honigmann, J. (1954:22) supports Agger by saying that in its technical sense "culture" is a short way of saying many things. Furthermore, Honigmann (1954:23) avers that the word "culture" points to two classes of phenomena, namely:

1. to the socially standardized behaviour, actions, thoughts, feelings of some enduring group.

2. the material products of, or aids to the behaviour of that group. Furthermore the term means to designate that these referents are bound together in some kind of a system or whole.

From the above discussion, one deduces that "culture" embraces everything, which contributes to the survival of man. Ayisi (1992:2) suggests that this will comprise not only physical factors but also sociological factors. He maintains that a distinction has been made between our biological and social needs.

In understanding that culture is an abstraction based on behaviour it is nevertheless possible to use expressions like "changing culture" or "the culture grows more complex." Such usages are quite figurative. Every once in the while it is well and good to stop and realize precisely what is changing or what is growing.

Agger, B. (1992:4) further argues that in its technical sense the term culture has a widely embracing meaning. To him, culture also refers to the trappings and symbolic objects (flags, signs, and traffic lights) used in everyday living. As indicated above, by culture one means an interrelated system of parts. The treatment of a child in the family bears a discoverable relationship to the aspirations and striving of future adults. Tracing 
connections between the various items in a community's repertory of behaviour represents one of the chief tasks of culture.

Casson, W (1981:50) shares the above explanations when he says about culture:

Culture is the heritage of learned symbolic behaviour that makes humans human. Culture is the heritage people in a particular society share.

He says that threads of human experience are twisted and woven in various designs. They need culture to separate them. Once more, the culture concept comes down to behaviour patterns associated with particular groups of people's "way of life". It consists of standards for deciding what is, ... for deciding what can be, ... for deciding what one feels about it, ... for deciding what to do about it, and ... for deciding how to go about doing it.

Culture, Casson tells us, is a system of symbols and meanings. It comprises categories or "units" and "rules" about relationships and modes of behaviour. To study culture therefore is the study of shared codes of meaning.

Goodenough, W. (1981:50) reserves the term culture for what is learned, for the things one needs to know in order to meet the standards of others. He refers to the material manifestations of what is learned as cultural artifacts. He further observes that the cultural differences among people are not simply in the things they behold, but in the standards by which they behold them. How people respond to these things and what they do with them indicates how they conceive of them, what they believe about them, how they value them, and what their principles are for using them. Culture, he says, is equated with behaviour and not with the standards that govern behaviour. It consists of the things we see people do and of the statistical patterning of events as we see them occur in a given community.

In mapping out the connection between culture and behaviour, Goodenough, W. (1981:55) declares that culture provides a set of expectations regarding what kinds of behaviour are suitable in given situations. Where suitable options are minimal, is it possible to predict the precise behaviour? Then too, people willfully violate the expectations a culture provides. It seems evident, therefore, that culture is not an instrument for predicting 
behaviour precisely at all, although as a set of standards for behaviour, culture helps to make behaviour much more predictable than it would otherwise be.

According to Goodenough, W. (1981:56) a valid description of a culture as something learned is one that predicts whether or not any particular action will be accepted by those who know the culture as conforming to their standards of conduct.

Geertz, C. (1973:12) shares Goodenough's description of culture when he stresses that human behaviour must be viewed as "symbolic action" and culture is what it means. "Culture is public because meaning is", he says.

Pertaining to the content of culture, Goodenough, W. (1981:61) looks at culture as a product of human learning, and then summarizes its content as follows:

1. The ways in which people have organized their experience of the real world so as to give its structure as a phenomenal world of forms, that is, their percepts and concepts.

2. The ways in which people have organized their experience of their phenomenal world so as to give it structure as a system of cause and effect relationship, that is, the propositions and beliefs by which they explain events and design tactics for accomplishing their purposes.

Mead, M. (1960:12) argues that the wholeness of a culture is not a statement that all cultures are integrated in the same way, or that all are equally integrated. Some cultures, she suggests, are so tightly integrated that any change threatens the whole. Others are characterized by a traditional pattern of manipulating events, which make it much easier to introduce particular changes without disturbing the whole way of life. Some societies have undergone profounded-recorded changes in their position in relation to surrounding peoples. These changes in orientation and response have themselves become part of the way in which the contemporary generation meets change.

Sometimes people resist new ways because the old have the sanction of the valued past or of religion. In such cases the worker often introduces change by using the sanction in support of it. 
Deducing from discussions about culture by various critics, it is clear that human culture is so complex that it seems unlikely that it will ever be possible to re-write prescriptions in such a form.

According to Mead, M. (1960:170), any change must be examined from the point of view of the individuals who are exposed to the change. It is, therefore, useful always to ask: "How does this change look to those whom it will directly and indirectly affect?" She further declares that any significant change in the life of an individual tends to introduce some degree of instability or disharmony in the way his life activities, his beliefs and attitudes are organized. To her, a significant change results in tension either because old behaviour is found to be inadequate or by creating new situations for which new behaviour must be acquired.

Nevertheless, whatever definition of culture one suggests, it should be clear that culture is concerned with meaning. Culture must by definition involve all things that give meaning and this is what separates people from other people. A culture is essentially the society's composite answer to the varied problems of life. Culture is a way of summarizing the ways in which groups distinguish themselves form other groups. It represents what is shared within the group, and presumably simultaneously not shared outside it.

Hofstede, G. (1984:21) shares the above argument when he writes:

Culture could be defined as the interactive aggregate of common characteristics that influence a human group's response to its environment. Culture determines the identity of a human group in the same way as personality determines the identity of an individual.

Moreover, Hofstede suggests that the two interact: "culture and personality" is a classic name for psychological anthropology. He says that cultural traits sometimes can be measured by personality tests.

Kluckhohn, C. (1952:317) argues that there should be universal categories of culture:

In principle ... there is a generalized framework that underlies the more apparent and striking facts of cultural relativity. All cultures constitute so many 
somewhat distinct answers to essentially the same questions posed by human biology and by the generalities of the human situation ... Every society's patterns for living must provide approved and sanctioned ways for dealing with such universal circumstances as the existence of two sexes, the helplessness of infants, the need for satisfaction of the elementary biological requirements such as food, warmth and sex; the presence of individuals of different ages and of differing physical and other capacities.

According to Hofstede, G. (1984:36) the kind of framework suggested by Kluckhohn must consist of empirically verifiable, more or less independent dimensions on which cultures can be meaningfully ordered. Hofstede further states that all cultures make decisions based on the importance placed in the values which load on four subsystems he calls Power Distance, Uncertainty Avoidance, Individualism and Masculinity. It appears that these are the dimensions around which basic values of a culture should be searched.

\subsubsection{Four dimensions of culture}

Culture patterns are rooted in value systems of major groups of the population. Hofstede, G. (1984:65) writes that the first of the four dimensions of national culture is called "Power Distance". According to him, the basic issue, to which different societies have found different solutions, is human inequality. Inequality, he elaborates, can occur in areas such as prestige, wealth, and power, different societies put different weights on status consistency among these areas. Inside organizations, inequality in power is inevitable and functional. He says that inequality is usually formalized in hierarchical boss-subordinate relationships.

Hofstede, G (1984:65) quotes the Mulder's Power Distance Reduction theory according to which subordinates will try to reduce the power distance between themselves and their employees. Their employees will try to maintain or enlarge it. This shows us that in every culture there is an identifiable hierarchy of classes. The labels given to them in everyday human communication define these classes. Through verbal and non-verbal language use, power distance is made visible. According to Mulder's theory many of these inequalities such as, the different statuses of president, employer, employee and all the ranks of military organizations, play an important role in operations of a culture. This theory suggests that there are both positive and negative inequalities in every society. 


\subsubsection{On defining Power Distance}

Hofstede, G. (1984:71) writes:

Power Distance is a measure of the interpersonal power or influence between Boss and Subordinate as perceived by the less powerful of the two, Subordinate.

Hofstede takes the above definition from the work of Mulder (1977:312). He maintains that Mulder's theory is based on a long series of laboratory and field experiments with simple social structures. Mulder as quoted by Hofstede (1984:71) defines "power" as "the potential to determine or direct the behaviour of another person more so than the other way round". He defines "power distance" as:

The degree of inequality in power between a less powerful Individual $(I)$ and a more powerful Other (O), in which I and $O$ belong to the same (loosely or tightly knit) social system.

Hofstede offers some of the twenty hypotheses, which have been proved by Mulder (1977:90). They are as follows:

1. The mere exercise of power will give satisfaction.

2. The more powerful individual will strive to maintain or to increase the power distance to the less powerful person.

3. The greater this distance from the less powerful person, the stronger the striving to increase it.

4. Individuals will strive to reduce the power distance between themse/ves and more powerful persons.

5. The smaller this distance from the more powerful person, the stronger the tendency to reduce it.

Hofstede (1984:70) continues by saying that:

Subordinates, as a group, are accessory to the exercise of power in a hierarchical system: The way the system functions reflect their collective 
complicity and the role relationship to which both parties contribute. Authority only exists where it is matched by obedience ... On the psychological level, the need for independence in people is matched by a need for dependence, and the need for power by a need for security, dependence and security needs stem from early childhood and are common to all mankind, independence and power are only developed later in our lives, if they are developed at all.

\section{Power Distance and Human Inequality}

Hofstede, G. (1984:72) writes:

If different cultures can be shown to maintain consistently different power distances in hierarchies, the Power Distance norm can be used as a criterion for characterizing cultures (without excluding other criteria).

Gasse (1976) as quoted by Hofstede (1984:72) argues that "each culture justifies authority using its major values" and then proceeds to picture a continuum of which the two poles are "monolithism" and "pluralism". At the monolithic pole, Gasse further suggests, cultures are characterized by power held by few people; at the pluralistic pole, competition between groups and leaders is encouraged, control by leaders is limited since members can join several organizations, democratic politics are fostered and information sources are independent of a single organization.

In reference to the work of Inkeles and Levenson (1969) by Hofstede (1984:72), ways of dealing with hierarchy and authority as a proposed criterion for ordering cultures are mentioned:

In a number of societies as remote from each other as imperial China and the Central African Kingdom of Burundi, the model of filial piety, associated with a rigidly hierarchical ordering of all social relations, draws together in a single formula masses of verbal and behavioural data. In parent-child relations, husband-wife relations, politics, religion, and economics, the same superordinate-subordinate pattern applies. 
Hofstede further suggests that the above quote means that a Power Distance norm spills over from one sphere of life - work organizations - into others. Moreover, he believes, it helps us to find the origin of a Power Distance norm in the early socialization by the family, the school, and the other institutions of society.

\subsubsection{Uncertainty Avoidance}

The second dimension of national culture as offered by Hofstede (1984:110) has been labeled Uncertainty Avoidance. He further argues that uncertainty about the future is a basic fact of human life with which we try to cope through the domains of technology, law and religion.

Hofstede (1984:111) further elaborates that:

Extreme uncertainty creates intolerable anxiety, and human society has developed ways to cope with the inherent uncertainty of our living on the brink of an uncertain future. ... The knowledge of a life after death is the ultimate certainty of the believer, which allows him to face uncertainties in this life.

He believes that different cultures solve their uncertainty problems in different ways. According to him, tradition does not only play a role in the behavioural norms of all cultures - either in compliance or rebellion, but it is also still a strong source of values for many cultures. To him, tradition is seen in all three domains of uncertainty avoidance. Hofstede describes uncertainty avoidance as the normative behaviour of a culture for the purpose of alleviating fears of the unknown.

Hofstede *1984:113) explains that:

Different societies have adapted to uncertainty in different ways. These ways not only differ between traditional and modern societies, but even among modern societies. Ways of coping with uncertainty belong to the cultural heritage of societies and they are transferred and reinforced through basic institutions like the family, the school, and the state. Their roots are nonrational, and they may lead to collective behaviour in one society, which may seem aberrant and incomprehensible to members of other societies. 
In the discussion of uncertainty avoidance, Hofstede (1984:118) further maintains that coping with the inevitable uncertainties in life is partly a non-rational process which is resolved in different ways by different individuals, organizations and societies. The tolerance for uncertainty (ambiguity), he believes, is the main underlying dimension, which can be found in individuals. This leads some individuals in the same situation to perceive a greater need for action thus overcoming the uncertainty than others do. Hofstede argues that tolerance for uncertainty is partly a matter of culture and personality. Societies differ in their societal norms for uncertainty avoidance. Moreover, members of these societies are socialized in the society's institutions toward this norm.

\subsubsection{Individualism}

Hofstede (1984:148) says that Individualism, which is the third dimension of national culture, describes the relationship between the individual and the collectivity prevailing in a given society. Individualism entails the source of the decision-making process which is essential to human and societal growth. Different styles of decision making evolved with the development of cultures. Individualism is visualized as the locus of the decisionmaking process on the individualism/collectivism continuum.

Hofstede sees the individualism dimension as being closely related to uncertainty avoidance and power distance. This is proved by the fact that it seems to have definite ramifications for each of them. Being high in individualism, he suggests, means being low in the other two.

When one defines individualism, one must juxtapose it with its counterpart, collectivism. According to Hofstede (1984:149) the relationship between the individual and the collectivity in human society is not only a matter of ways of living together. He suggests that it be intimately linked with societal norms. It affects both people's mental programming and the structure and functioning of many other types of institutions besides the family: educational, religious and political. Hofstede further cites an example of the consequence of a more individualistic or more collectivistic self-concept, which is the case of religious or ideological conversion. He explains that in western individualist society, converting oneself is a highly individual act. If he would convert himself to, for example, Catholicism, it is unlikely that even his closest relatives would follow him. Nevertheless, he suggests, the history of all great religions is one of collective rather than individual 
conversion. Because they are tied to value systems shared by the majority, issues of collectivism versus individualism carry strong moral overtones.

Dizard (1982) as quoted by Hofstede (1984:119) recommends that even in the tradition driven segment of our population, the farmers have a real sense of individualism, namely, their independence and self-sufficiency. The farmers would help each other during the harvest, when the farms were all small. As technology grew, so did the size of the farms, and the collective spirit disappeared.

Borden (1976:111) quotes Lidz (1976) who reinforces the importance of the culture in the development of the individual as follows:

A culture, then, has become an essential part of the human endowment. To examine the influence of the culture upon personality development is not to continue an old conflict concerning the importance of cultural versus biological factors in personality formation, but simply to recognize that the biological nature of the human organism is such that it depends upon the assimilation of cultural instrumentalities to make possible survival and development into a person. The culture in which the child is raised serves as a mold to shape the rough outlines of the personality, delimit drives and provide organization to the manifold ways of adapting to the environment permitted humans by their physical endowment. Although the repressive and limiting influences of society have been bemoaned, delimitation is essential to the realization of potential. A person cannot develop into a harmonious entity without it. Without the skills and customs provided by society, a child cannot become anyone at all.

In individualistic cultures, Borden (1976) suggests, even the focus on the person, as opposed to the individual, stress the importance of individualism.

\subsubsection{Masculinity}

Hofstede (1984:176) offers the fourth dimension along which national cultures can be shown to differ systematically. This has been called Masculinity. Its opposite pole is called Femininity. According to him: 
The duality of the sexes is a fundamental fact with which different societies cope in different ways.

The issue, Hofstede continues, is whether the biological differences between the sexes should or should not have implications for their roles in social activities. The sex role distribution common in a particular society is transferred by socialization in families, schools, and peer groups, and through the media. According to Hofstede:

The predominant socialization pattern is for men to be more assertive and for women to be more nurturing.

Hofstede further explains that in organizations, there is a relationship between the perceived goals of the organization and the career possibilities for men and women. He says that business organizations have "masculine" goals. They tend to promote men. Hospitals, he believes, have more "feminine" goals and the nursing side tends to promote women. Hofstede elaborates by labeling the "masculine/feminine differences as ego/social":

With ego characteristics being the need for challenge, advancement, recognition, and earnings, and the social characteristics being the need for a good manager, co-operation, desirable area, employment security, and a friendly atmosphere.

The above mentioned characteristics, Hofstede maintains, are practically identical to the characteristics developed above for masculine/feminine. He declares that the ego end of the continuum is high masculinity. The social end is low masculinity. To him, high masculinity can be seen in a number of different dimensions:

Objective vs subjective

Success oriented vs relational oriented

Active vs passive, etc. 
Furthermore, Hofstede (1984:205) adds:

Cultural characteristics will likewise reflect these attributes - high stress, leaning toward the individual and decision maker rather than the group, preferring large companies to small, and feeling that knowing people is more important than an ability to get ahead. Job satisfaction is correlated with the feeling of challenge and the satisfaction with earnings. In a sense, highmasculinity cultures "live to work" and low-masculinity cultures "work to live".

\section{Sexes and sex roles}

Hofstede (1984:177) informs us that in human societies of all ages and levels of complexity, this nature-given fact has been regarded as one of the very first issues with which the society had to cope in its own specific way. He says that a multitude of societal institutions has been profoundly affected by it. Hofstede's views on gender role rigidity is shared by Chetwynd and Hartnett (1978) whom he quotes:

The sex-role system is at the core of our cultural norms.

Among the vast majority of societies, both traditional and modern, Hofstede argues there is a common trend, as to the distribution of sex roles. He comments that men must be more concerned with economic and other achievements. Women must be more concerned with taking care of people in general and children in particular. This shows that masculinity is identified with traits and behaviours such as strength, speed, assertiveness, competitiveness, dominance, anger, ambition, and the pursuit of wealth. Feminine characteristics and behaviours are associated with emotionality, affection, compassion, warmth, and nurturing of the weak and needy. The above traits and behaviours are results of Bern's (1974) Sex Role Inventory of adjectives which was a sample of male and female students in the United States of America, as quoted by Hofstede (1984:179).

According to Hofstede, Bern's studies show that the actual behaviour need not correspond to the stereotype. Moreover, differences here are statistical rather than absolute. He elaborates by saying that the fact that an active feminist movement exists in a number of countries is a clear indication that some women (and also some men) no longer take the 
traditional pattern of male dominance for granted; instead they try to develop alternative role distributions.

In gender-related behaviours, certain behaviours are generally associated with males or females regardless of culture. For instance, in most cultures, graceful movements and nonverbal inviting behaviours are predominantly used by females and are avoided by males.

Masculine cultures tend to be less tolerant of feminine behaviour from males, and vice versa. On the other hand, a feminine culture tends to tolerate more deviations in norms and behavior.

Hofstede (1984:200) has developed an index rank ordering countries with respect to four cultural dimensions. Gender role rigidity is one of those dimensions. He says that the ten countries with the highest masculinity index are Japan, Australia, Venezuela, Italy, Switzerland, Mexico, Ireland, Great Britain, Germany and the Philippines. American people of both sexes seem to be loud, aggressive and competitive compared with the people of most countries. Emotional expressions, such as crying, are associated more with femininity whereas masculine people are more dominant, argumentative, assertive and goal oriented.

Across the occupations, Hofstede found the following significant sex difference trends in his survey:

\begin{tabular}{|l|l|}
\hline \multicolumn{1}{|c|}{ MORE IMPORTANT FOR MEN } & \multicolumn{1}{|c|}{ MORE IMPORTANT FOR WOMEN } \\
\hline Advancement & Friendly atmosphere \\
\hline Earnings & Position security \\
\hline Training & Physical conditions \\
\hline Up-to-dateness & Manager Cooperation \\
\hline
\end{tabular}

Hofstede explains that the above analysis suggests that there may be an interaction between sex and education, in that in the higher educated occupations, the women would be more job-content-orientated than the men would. On the other hand, in the lower educated occupations the opposite would be the case.

Hall (1965) as quoted by Hofstede (1984:201) offers us case descriptions in the anthropological literature, which fit the masculinity scores. He writes: 
In Iran ... men are expected to show their emotions. Iranian men read poetry; they are sensitive and have well-developed intuition and in many cases are not expected to be too logical. They are often seen embracing and holding hands. Women, on the other hand, are considered to be coldly practical.

Hofstede suggests that much of societal masculinity-femininity differences must be historically and traditionally determined, in the same way as anthropologists report differences in sex role differentiation between similar tribes, which can only have historical/traditional origins.

As argued earlier on by Hofstede, the crucial link in the transfer of sex role patterns must be the family, in which children model their sex role self-concepts after the values in use which they notice in the adults of both sexes with whom they are in contact. Moreover, he avers the sex role pattern is transferred together with other values. Hofstede maintains that power distance is also transferred in the family. He assumes it to reflect the degree of absoluteness of the authority of adults, but mostly of the fathers, over the children. According to him:

Masculinity or femininity is then related to the difference in roles between the parents or other male and female adults. For the transfer of power distance the role of the father is most crucial; for the transfer of masculinity the role of the mother is crucial.

\subsection{OVERVIEW OF GENDER STUDIES}

Bonvillain (1997:27) considers that the literature on women, both feminist and anti-feminist is a long rumination on the question of the nature and genesis of women's oppression and social subordination. More importantly, so she elaborates, the analysis of the causes of women's oppression forms the basis for any assessment of just what would have to be changed in order to achieve a society without gender hierarchy. She takes this argument a step further by observing that if innate male aggression and dominance are at the root of female oppression, then the feminist program would logically require either the extermination of the offending sex, or else a eugenics project to modify its character. 
According to Billing et al. (1997:9) gender is a historical phenomenon which is understood, developed and changed differently in different cultural context and times. They further maintains that there is variety between, as well as within, societal cultures. In elaborating on this aspect, they declare that men, women and gendered practices are dynamic, at least in modern society. They were different a decade ago and they will be different in the future.

In their opinion, the purpose of gender studies is to facilitate advanced thinking and reflection about gender and, thereby, about social relations, society organizations and working life in general. Pertaining to this line of thinking everything thus bears a significant gender meaning and reflects or constitutes gender bias, normally to the advantage of men or to forms of masculinity.

Friedman (1989) as quoted by Marsden, D.F. (1994:100) points out that:

Gender power relationships are maintained in society by the creation of "distinctions between male and female spheres - and it is the reproduction of these distinctions, which accounts for the persistence of the so-called 'naturalness' of it all."

Furthermore, he says that in some cases, the image of women languishing under the yoke of oppression titillates and permits men to place themselves in the superior position. That is why all over the world there are bodies on gender equality. These bodies, he discloses, seek to protect and develop equality between sexes and to empower women. It is through gender equality bodies that one determines what is good in one's culture, what is bad and what one must do away with. Gender equality therefore cannot be divorced from issues in society.

In trying to differentiate between sex, gender and tradition, Bonvillain (1997:2) points out that people in every culture maintain that women and men perform the rights they have in relation to each other and the values associated with the activities. She further observes that taken together, these ideas comprise culturally shared and accepted models of gender. These, she maintains, are social constructs, developed and sustained specifically within each culture. Gender constructs, she says, obviously make use of sexual differences between males and females, but they are not contained in a predetermined 
manner by these sexual differences. She believes that if they were, roles performed and values attached to women's and men's behaviour would be identical in all societies.

Marsden, D.F. (1994:2) advises that the subject of representations of South African women cannot be viewed from the single dimension of the written text. She thinks that representations have to be contextualised against the broader backgrounds of South African and African literature and literary critical theory. This in turn has to be contextualised against the social, historical and political backgrounds, which produce them.

Gender studies are dominated by feminism. Various critics define feminism in different ways. It is said to be a movement to end sexist oppression. Hooks, B. (1984:1) explains that:

Feminism in the United States has never emerged from the women who are most victimized by sexist oppression, women who are daily beaten down and women who are powerless to change their condition in life. They are a silent majority.

Taylor (1999:3) gives his views on gender issues by suggesting that gender relations can be characterized on a continuum from full equality to the complete domination of members of one gender by members of the other. He believes that the notion of gender equality is used to refer to a constellation of behaviours, attitudes and rights that support the autonomy of both women and men.

Women and men, he maintains, may have different economic, social and political roles, but the valuation and rewards given to them are roughly similar. In such systems, all people have access to equal rights, prestige, ability to make decisions for themselves and others, and autonomy in their households and communities. In contrast, gender inequality refers to denial of autonomy and equal rights to one group of people based on their gender.

Gender equality is more likely to exist in foraging band societies where all individuals make important contributions to subsistence and where hierarchical leadership is absent or minimal. 
To elaborate further on the question of women issues, Dowling, D.S. (1997:14) declares that women studies discusses the whole predicament of women merely in terms of their not having the same opportunities as men. Normally, she avers, the remedy prescribed is government legislation of an equality package for women. According to her, the legislation in question ought to cover such things as "equal opportunity in work" and equal pay for the same work - equal opportunities in education, in politics, in sport, and so on.

Wollstonecroft (1995) as quoted by Dowling (1997:14) questioned the traditional belief that women should be dominated by men just because men are naturally dominant. Women, she suggests, are dependent upon men because they are naturally inclined to dependence. According to this male tradition, sex is not a mere contingency; rather it determines the entire nature and role of a person. She says it was thought that a women ought to have a different education, moral value, role in society, and an entirely different function in the household, from that assigned to a male. In other words, as a result of the sexual difference, male and female are quite different ways of being human. This in turn requires the domination of women by men. She supports her views by noting a philosophical argument, which can be found in the writings of Rousseau, in his book, Emile, Book V. Rousseau maintained that "by the end of his ideal education, the young man's accomplishments and experience ought to include the ability to support himself, if necessary with a trade, so that he is independent of the goodwill of charity of other men". He ought to be familiar with the arts and the sciences, with government, the laws and public affairs in general. When it comes to his relationship with women, Emile is told by his tutor:

You hope to be a husband and a father: have you seriously considered your duties? When you become head of a family you will become a citizen of your country.

Gleaning from what is being said by Emile's tutor, Dowling deduces that marriage for Emile ought to involve his proper inclusion into the body politic, whereas his family ought only to be connected to society through him by virtue of his being the head of the household. In contrast, a woman's education ought to be quite different because the works of genius are beyond her reach. She has neither the accuracy nor the attention for success in the exact sciences. It is claimed that as a result, a woman's thoughts should be directed to the study of men. It is also believed that a woman is specially made "by 
nature" for man's delight. Dowling believes that Rousseau is in no doubt that the sexual difference between a man and a woman requires that a man be the head of the household, his wife to be subservient to him.

Bonvillain, N. (1997:29) believes that it is not surprising that there have been numerous attempts to apply Marxist analysis to the question of women because there is no theory that accounts for the oppression of women - in its endless variety and monotonous similarity, cross-culturally and throughout history. She says there are many ways of doing this. It has been argued that women are a reserve labour force for capitalism, that women's generally lower wages provide extra surplus to a capitalist employer, that women serve the ends of capitalist consumerism in their roles as administrators of family consumption, and so forth.

Dowling, D.S. (1997:15) has this to say about the theory of Marxist feminists:

Marxist feminists do not give us an adequate theory of the subordination of women. Their account is, at best, incomplete. For instance, although Marxist feminists are concerned with the oppression of women in family life, they rarely address this oppression unless it is part-and-parcel of a wider economic and political analysis.

She further maintains that Marxist feminists consider sexuality and conflict between the sexes only when it intersects with the underlying economic analysis. Moreover, she claims, the belief seems to be that equality between the sexes will automatically transpire when the economic basis of society is transformed into an egalitarian socialist model. Dowling believes that changing the socio-economic structure is not enough. There must also be a change in the personality of men. One cannot help but agree with her when she explains that men have to be taught new behaviour. Interpersonal relationships are of great importance.

Nevertheless, Dowling commends the interesting insights contributed by Marxist feminism in women's studies, though many areas of discrimination against women are left lying outside of the theory. 
Drawing on the work of various critics discussed above, it is evident that gender is an issue that deeply influences transference and countertransference. For women to be in a position where they can learn to love themselves and become "woman identified", women need to break oppressiveness. The content of gender and the content of sexuality are identical as expressed in the linkage of the two in the word "sex".

Women's identity is constituted by women's position as victim. This does not mean that being a woman entails passivity. Women can negotiate, strategize against and fight their oppression. Nevertheless, all such actions represent responses to the condition of powerlessness that defines what it means to be a woman. Women are objectified and as such one of the aims of gender commissions is to transform this objectification. Objectification can create a sense of emptiness, non-existence as well as nothingness in women. Masses of women are concerned about economic survival, ethnic and racial discrimination etc. As Dowling (1997:23) observes, "objectification is the psychic scar tissue that results to living with the expectation of being a battlefield sacrifice, which is as horrible as the suffering women bear from the fear and the reality of rape."

\subsection{OVERVIEW OF DRAMA}

According to Pickering (1981:88) the word "drama" comes from the Greek word "draó" (I do, I act) and "dran" (to do, to act). The term "drama" refers to a particular genre and prose and poetry are the other two main genres, which are usually distinguished.

In plays, stories and drama each action or speech are of tremendous significance because they are part of a total portrait, as suggested by Roberts (1992:65). Furthermore, he elaborates:

Whereas in life things may "just happen", in literature all actions, interactions, speeches, and observations are deliberately selected and designed.

Gleaning from Roberts's statement, it makes sense therefore that in the analysis of any drama, attention should be focused on how well the drama deals with literary aspects such as plot, character and theme. 


\subsubsection{Plot}

Plot means the arrangement of events in order to achieve a specific artistic effect. Dramatic characters are derived from life, and so are the things that they do. The things, which they do, are actions or incidents and they occur in chronological order. Once the chronological order has been established, the plan of development of the actions still has to be considered.

Roberts (1992:51) argues and rightly so, that without a plot, we do not have a story or drama. In addition, he says:

A plot is a plan or groundwork of human motivations, with the actions resulting from believable and realistic human responses.

It is evident from the above statement that the use of chronological order is important not because one thing happens after another, but because it happens because of another. Roberts sums it up by suggesting that "it is response, interaction, causation and conflict that make a plot out of a series of actions".

The internal structure of drama is characterized by phases, which reflect dramatic action in its various stages. The presence of these phases is of immense value in the development of events in a drama. Dramatic phases are divided into the exposition, the motoric phase, complication, climax and denouement.

\section{(l) Exposition}

This serves an introduction that brings out brief references to the principal characters, circumstances and various issues of the plot.

(II) The motoric phase

Boulton (1980:40) explains the motoric phase as: "Some startling development giving rise to new problems." 
He calls this phase the first crisis. Madazhe (1985:45) maintains that the events introduced in the beginning of a drama should start "walking". One shares his views when he explains that in this phase, the relationship between characters should lead to something either good or bad. Moreover, he suggests, a character's nature should be revealed to the audience and readers through action.

\section{(III) Complication}

Boulton (1980:60) defines complication as follows:

This first crisis will lead on to other actions, events or modifications of character, which may in their turn have new consequences carrying the play further forward. Probably the whole plot now proceeds for some time from crisis to crisis. The crisis may succeed one another as crisis and effects, or some fresh crisis may arise from another cause.

Clearly, gleaning from the above statement the culmination of the motoric phase leads to the introduction of the complication phase in dramatic action. It is the onset of the major conflict.

(IV) Climax

Roberts (1992:57) has this to say about climax:

The climax (Greek for ladder) is the fulfillment of the action undertaken in the crisis, and it is hence the high point in the structure.

He elaborates by explaining that "it is the logical conclusion of all the previous tension and uncertainty when all doubts and mysteries are ended".

Brooks and Heilman (1964:70) share Roberts's views when they observe climax as:

The most intense moment of conflict, the turning point. 
Summarily therefore, climax is the pinnacle of the problem. Events that have been building themselves up in an ascending order should reach their highest peak.

(V) Resolution or denouement

According to Roberts (1992:59) denouement is the resolution (a releasing or untying) or the finishing of things after the climax.

Once the "untying" begins, he elaborates, there is no more tension and uncertainty, and most authors conclude as quickly as possible. As Jafta (1978:82) noted, in the denouement there is a new pattern that has been developed from the climax.

Because in drama something happens because of another thing, it makes sense therefore to explore the cornerstones of plot structure in drama.

\subsubsection{Characters}

Abrahams (1988:22) maintains that:

Characters are the persons presented in a dramatic or narrative work, who are interpreted by the reader as being endowed with moral, dispositional, and emotional qualities that are expressed in what they say - the dialogue - and by what they do - the action.

Hees et al. (1988:122) share the above view when she explains how characters function:

Characters in a play are in some way a vehicle whereby the dramatist conveys his central theme.

Roberts (1992:65) goes further and says that in studying a literary character, one should determine the character's major trait or traits. He defines a trait as:

A mode of behaviour or quality of mind, such as acting first and thinking later, or thinking oneself the constant center of attention. 


\subsubsection{Types of characters}

Roberts (1992:65) quotes Forster who explains that there are two kinds of literary characters, "round" and "flat".

According to the different authors, there are many types of characters but for purposes of this study it makes sense for one to explore the following types of women characters, protagonist, antagonist and tritagonist.

\section{(l) Protagonist}

Conradie (1978:52) defines the protagonist as follows:

Die protagonis is die hoofkarakter of held wat in die drama die sterkste op die voorgrond tree en die toneel van die begin af oorheers. Dit gaan in die drama veral om sy worstelinge, sy gevoelens en sy uiteindelike lot.

From the above definition, it is clear that the protagonist is the main character who dominates events from the beginning to the end of the drama.

Smiley (1971:96) claims that the protagonist is a focal character. Furthermore, he elaborates, the protagonist influences and precipitates the action or plot. On the other hand, Sirayi (1993:63) suggests that it is important to note that some critics contend that there is a difference between the protagonist and the hero. He quotes Dietrich and Sundell (1974) who remark:

... the protagonist is also the hero, defined as an admirable character who embodies certain human ideals... But the protagonist is not always admirable, and therefore not always heroic. The reader may identify with the protagonist for no other reason than he is undergoing a difficult experience that wins the reader's sympathy...

Furthermore Sirayi (1993:64) explains, both the protagonist and the hero are main characters and are endowed with various qualities. He says that "the protagonist is identified as the character undergoing a difficult experience that elicits the attention and 
sympathy of the reader". Protagonistic attributes, he suggests, are determined by the afflictions encountered in life.

\section{(II) Antagonist}

An antagonist on the other hand may be regarded as an opponent of a protagonist. He or she opposes everything the protagonist stands for.

Madadzhe (1985:86) explains that the word antagonist is derived from "anti" which means against and "agonistes" a champion. According to Conradie (1978:24) the antagonist is:

Die teenstaander wat die worsteling en krisis by die protagonis veroorsaak, die agtervolger, bedrieër, of kweller.

It is clear therefore that the main function of an antagonist is to oppose the protagonist.

\section{(III) Tritagonist}

The tritagonist is a supporting character whose function is to mediate the existing conflict. That is why Conradie (1978:24) defines it as follows:

...die tritagonis, die karakter wat tussen die twee strydende partye staan en verskillende rolle kan vervul.

Sometimes, Madadzhe (1985:91) says, the tritagonist endeavors to arbitrate between a protagonist and an antagonist and by so doing may lead to greater confrontation between the two. Furthermore, he elaborates, a tritagonist's interference in the affairs of both the protagonist and the antagonist may result in a sound relationship between them. $A$ tritagonist therefore is indispensable in a play.

\section{(IV) Round and flat characters}

About round characters, Roberts (1992:60) observes that the basic trait of round characters is that they recognize, change with, or adjust to circumstances. He says that 
round characters are relatively fully developed and it is for that reason therefore they are often given the names "hero" or "heroine".

Roberts (1992:66) argues that "because many major characters are anything but heroic, it is preferable to use the more neutral word protagonist, which implies only that a character is a center of attention, not a moral or physical giant." In addition, he says:

The protagonist is central to the action, moves against an antagonist, and exhibits the same qualities of living and adapting characters.

From the above statements one gathers that because round characters are unpredictable and because they undergo change or growth, they are dynamic. It is also obvious that round characters are the focal points of conflict and interest and skillful authors use these types of characters to clarify certain issues and enable the readers to understand the dynamic processes by which round characters develop and grow.

Roberts (1992:66) further observes that flat characters in contrast to the round characters do not grow. He says, "flat characters are flat because they may be stupid or insensitive, or because they may lack knowledge or insight." In some instances, anyway, because flat characters are sometimes prominent in certain types of literature like police in detective stories they should be lively, even though they do not develop or change. They should nevertheless be clever enough to perform recurring tasks, as suggested by Roberts (1992:67).

\subsubsection{Character, dialogue and action}

In drama, dialogue cannot be isolated from the dramatic character. Characters communicate mainly through what they say. Keuris (1996:59) observes that a character communicates mainly through what he says. In addition she says that dramatic action is also often included in what a character has said, or follows from the spoken word. One shares her observation in the fact that the character's actions usually carry more weight than his words.

Through characterization in dialogue Brooke (1995:107) explains: 
... we learn who the story characters are in the community, who they are to themselves, what their emotional motives are and how far they're likely to go to get what they want.

There are various types of dialogue, such as song and monologue. Mabley (1972:29) makes the following statement about dialogue:

Dialogue performs various functions: it depicts the speaker and the person spoken to, it reflects the relationship of the speaker to other characters, it reflects the speaker's mood, conveys his emotion, and it foreshadows what is to come for the characters.

Dialogue is certainly one of the most popular tools employed by the playwright to reveal his characters. The most important resource of the playwright still remains the spoken word. Another aspect of the presentation of character as suggested by Brooke (1995:209) concerns the development of character. She states that one of the commonest criteria for judging a dramatist's skill in characterization is to ask whether he has successfully "developed" his characters. The development of a character is really the development of a situation in which the character is involved.

\subsubsection{Conflict}

Conflict is one of the cornerstones of drama and it is the most significant element of plot. According to Roberts (1992:52) conflicts may be the opposition of two people in its most elemental form. Conflicts, he suggests, may also exist between groups.

Conflict is said to be the major element of plot because opposing forces arouse curiosity, cause doubt and create tension. It determines the success or failure of a drama. Its significance is summed up by Dancyger (1990:5) when he says: "Drama means, in brief, conflict." 


\section{CHAPTER 2}

\section{PLOT STRUCTURE IN THE FIRST LITERARY PERIOD (1958-1965)}

\subsection{AIM}

The discussion that follows seeks to examine the artistry of the playwrights of the three periods being studied in the handling of their plot structure. The aim is to explore whether these dramas treat issues and themes, which become central to the formal and structural ordering of the drama. In the process such themes have an impact, at times, on form and structure. In various respects, then, these ten dramas have an importance that cannot be overlooked. The following are the ten dramas under study from the three literary periods:

(a) $1958-1965$

$\begin{array}{llr}\text { Tamsanqa, W.K. } & \text { Buzani kubawo } & 1958 \\ \text { Mmango, A.M. } & \text { UDike noCikizwa } & 1963 \\ \text { Mtingane, A. } & \underline{\text { Inene nasi isibhozo }} & 1965\end{array}$

(b) $1973-1982$

$\begin{array}{llr}\text { Jongilanga, D.M. } & \text { Ubusuku obungenanyanga } & 1973 \\ \text { Qangule, Z.S. } & \underline{\text { Amaza }} & 1974 \\ \text { Mtywaku, D.T. } & \underline{\text { UFeziwe okanye inkohlakalo }} & 1982\end{array}$

(c) $1988-1997$

$\begin{array}{llr}\text { Mkonto, B.B } & \text { Emgxobhozweni } & 1988 \\ \text { Mcimeli, R. } & \text { lintombi zinecebo } & 1992 \\ \text { Mothlabane, H. } & \underline{\text { linkunzi ezimbini }} & 1994 \\ \text { Ngewu, L. } & \text { Yeha-a mfazi obulala indoda } & 1997\end{array}$

Each of these three periods will be treated in separate chapters. In this chapter the first period will be given attention to, while the other two periods will feature in chapters 3 and 4 respectively. 
The discussion of the first three dramas will include an analysis of the plot structure of these dramas as well as the themes that they give attention to. This section will also include an evaluation of the dramas in this period.

\title{
2.2 PLOT STRUCTURE
}

\subsubsection{Buzani kubawo (W.K. Tamsanqa, 1958)}

\subsubsection{Episodes}

In order to give the reader a better understanding of this drama, a short summary will be supplied before the analysis.

\section{EPISODE 1: EXPOSITION}

In Buzani kubawo, the main characters, namely Gugulethu, Zwilakhe, MaGaba, NomaMpondomise and Nozipho have been introduced as from the beginning of dramatic events. It is clear that the whole drama centres on the relationship between these characters. The rural setting of Buzani kubawo has been explicitly portrayed in the exposition.

The manner in which expository events are presented is another main point, which is of tremendous significance. The language, which is in the form of symbols and words used by characters, is full of sense, feeling and emotion. One cannot help but commend Tamsanqa for this artistic device because his words convey emotion to the audience and through this his drama does achieve its purpose, that is, to educate and entertain. For instance, Tamsanqa in this drama attracts viewers' and readers' attention by opening his play by a song sung by Nozipho:

\author{
Dili-i-ka Thando \\ Dilika Thando Iwam, \\ Dili-ka Thando Iwam \\ Dili-i-ka Thando Iwam!
}




\section{Crumble Love \\ Crumble my love \\ Crumble my love \\ Crumble my love!}

Act I, Scene 1:1

The song is pregnant with hints of future and impending events. It is a pointer to what will happen later. This is symbolic of Gugulethu's love for NomaMpondomise, which is crushed by his father's stubbornness and Gugulethu's happiness crumbles irreparably when his lover, NomaMpondomise, drowns herself in the river.

From the beginning of the drama, Zwilakhe and MaGaba discuss the marriage of their son Gugulethu. MaGaba suggests the name of Thobeka, which Zwilakhe also appreciates. Meanwhile Gugulethu is busy preparing himself to propose to NomaMpondomise, who is also attending the wedding ceremony at Ngoqo. It is also in this very interesting exposition that the author presents us with Gugulethu who is singing a symbolic song, which is a hint of impending events. While drinking, Gugulethu sings thus:

\footnotetext{
I want to be ready

I want to be ready

I want to be ready

To walk in Jerusalem

Just like John
}

Act I, Scene 1:2

This song can be interpreted as a prayer of invocation unconsciously sung by Gugulethu to be ready for his death. If Gugulethu had known that his days are numbered he would not sing out. He is symbolically beseeching God to be with him, as later on he directly sings so:

Gugulethu: O! Nkos'uzube nam, uzube nam,

Nkos'uzube; nam, zube nam.

Indima 2: Umboniso 3:25

Guguletu: O Lord be with me 
The wedding ceremony, which is attended by Gugulethu and Mzamo, his friend, finally brings Gugulethu and NomaMpondomise together. This really marks the end of peace in the house of Zwilakhe. Both NomaMpondomise and Gugulethu make their own choices about who to love and marry. This gives rise to the first crisis.

\section{EPISODE 2: MOTORIC MOMENT}

Boulton (1980:78) regards the motoric phase as:

Some startling development giving rise to new problems.

We may call this the FIRST CRISIS.

The events introduced in the beginning of a drama should start "walking". So is the case in this drama. Characters' nature and preferences are revealed to the readers and viewers through action. In their discussion about Gugulethu's marriage, Zwilakhe and MaGaba agree with each other that Gugulethu must marry Thobeka. This is proved beyond doubt by the following extracts. MaGaba says:

MaGaba: Mna zinkosi andikhathali nokuba umntu uchasa ade alale ngomqolo phantsi, ndifuna intombi kaMcothama...

Indima 2, Umboniso 1:21

MaGaba: I do not care even if someone opposes this vehemently, I want Mcothama's girl.

Act 2, Scene 1:21

Zwilakhe shares MaGaba's views when he says:

Zwilakhe: Andikhathali nokuba umntu sel'esithini. Ukuba ndithe uza kuzeka intombi ethandwa ndim, uza kwenza loo nto ke

Indima 2, Umboniso 1:22

Zwilakhe: I do not care what anyone says. If I say he will marry a girl of my choice, he will do just that. 
Zwilakhe tells Gugulethu to marry Thobeka. Gugulethu shows his unhappiness about this decision. In the meantime Gugulethu receives a letter from NomaMpondomise which informs him that she has accepted his proposal. Zwilakhe on the other hand arranges with his brothers that they should go to Mcothama's house to ask for the girl, Thobeka. This creates another crisis because the whole arrangement is against Gugulethu's will. Zwilakhe once said to his son, Gugulethu that he does not have to be spoon-fed because he is a man of marriageable age. He is now making his son's choices for him, so Gugulethu tells his father that he contradicts himself. This changes the relationship between the two. Gugulethu says to his father:

Gugulethu: Ixoki lona sewuzenze lona Rhadebe ngokuthi andintanga yakufunzwa utsho undimele ngecephe undifunza. Uyabona ke mandikuphe le nyaniso. Nosana olu sewulufunza, ukuba ukutya alukufuni, alukufuni. Womana uluvingca iimpumlo ulufuthanisela... Kanti ke yingozi leyo kuba usana losuka lutsarhwe, ukutya kuhle ngandleia zimbi kuba aluginyi ngakuthanda. Kuza kuba njalo ke apha kum. Ndithe andiyifuni nje laa ntombi andiyifuni, ndaye andisayi kuze ndiphinde ndithi ndiyayifuna.

Indima 2, Umboniso 1:23)

Gugulethu: You have presented yourself as a liar already by saying that I have passed the stage of being spoon-fed meanwhile you are busy doing just that. Look here, let me give you this truth: you cannot force even a baby to eat when he does not want to. That is very dangerous because the baby can be choked if he eats against his will. The same thing will happen to me. I told you that I do not want that girl and I mean it. I'm not going to change my decision and say I want her.

Act 2, Scene 1:23

Gugulethu's words from the given extract suggest that he is not prepared to marry Thobeka. These words compel us to delve into the events of the next phase. 


\section{EPISODE 3: COMPLICATION}

The culmination of the motoric phase leads to the introduction of the complication phase in dramatic action.

Boulton (1980:91) has this to say about complication:

The first crisis will lead onto other actions, events or modifications of character, which may in their turn have new consequences carrying the play further forward. Probably the whole plot now precedes for some time from crisis to crisis. The crises may succeed one another as causes and effects, or some fresh crisis may arise from another cause. This may be called COMPLICATION.

In Tamsanqa's Buzani kubawo one crisis follows another systematically. Incidents go from bad to worse. There are characters who intensify their actions which are calculated towards one another's efforts. For instance, Zwilakhe and his brother go to Mcothama's place to pay out lobola and decide on a wedding day. This is against Gugulethu's will and he is deeply disturbed. Zweni, realizing that Gugulethu is in a bad mood, wants to know what the matter is. Gugulethu replies by saying:

\section{Gugulethu: ... kwaye alikho ithemba lokuba ndoza ndibuye ndibe sekukhanyeni ... buzani kubawo}

Indima 2; Umboniso 5:38

Gugulethu: $\quad \ldots$ and there is no hope that l'll ever be in the light again. ... ask father

The above speech suggests that all doors for positive communication have been closed. There is now a strain in the relationship between Zwilakhe and Gugulethu. The first crisis leads on to other actions. While Thobeka's lobola is paid, NomaMpondomise drives away the cattle that are paid for lobola by Mcunukelwa. She does this because Gugulethu has promised to marry her. The driving out of cattle marks NomaMpondomise's change of life. To show his bitterness and disappointment, Langeni, NomaMpondomise's father says to his daughter: 
Langeni: Kulungile ke ntomb'am, yenza ngokokubona kwakho... Nanzo ntombi yam zikhuphe, kodwa ntombi yam uya kundikhumbula. Ndinguyihlo ndisitsho nje.

Langeni: All right my girl, do as you wish... There they are: drive them out, but my girl you'll remember me one day. I say so because I'm your father.

Act 3, Scene 6:60

\section{EPISODE 4: CLIMAX}

Climax, Brooks et al (1964:65) once said, is the most intense moment of conflict, the turning point.

Climax is the pinnacle of the problem. Characters may engage in fights which may lead to death. As the events develop in an ascending fashion, the emotional intensity builds up to such an extent that something cracks; this is the crisis or the turning point.

In Buzani kubawo, Zwilakhe decides the wedding day for his son, Gugulethu. Gugulethu is silent and motionless. At this stage Gugulethu reaches the zenith in arguing against a forced marriage. When he is eventually asked to repeat the marriage vows by the officiating pastor, he keeps a dramatic silence:

Umfundisi: Ke mfana wothi ulandele kumazwi endiza kuthi ndiwathethe kuwe. "Ndivakalisa ndinyanisile ukuba andazi sithintelo ngokwasemthethweni sokuba mna Gugulethu andingeze ndamanywa emtshatweni noThobeka." Qhuba ke mfana wam.

Indima 4, Umboniso 1:63

Pastor: Young man, will you repeat the words I'll be saying to you after me. "I say truly that nothing as regards law can prevent me from marrying Thobeka." Proceed young man. 
UGugulethu: (cwaka)

Gugulethu: (silent)

Umfundisi: Qhuba kaloku mfana wam

Pastor: $\quad$ Proceed young man

UGugulethu: Gqitha mfundisi

Gugulethu: Proceed pastor

Umfundisi: Uthini na ukuthi mandigqithe?

Pastor: How can you say that I must proceed?

UGugulethu: Buza kubawo

Pastor: Ask father

Indima 4, Umboniso 1:63

Act 4, Scene 1:63

Gugulethu's public refusal to respond positively to the officiating pastor is the pinnacle of the problem. What transpires from the above extract is the basic issue of this drama (the name of the book) Buzani kubawo (ask father). The pastor is shocked by Gugulethu's reaction. The pastor calls Zwilakhe and he is the one who accepts Thobeka as a wife on behalf of his son. Zwilakhe says:

Zwilakhe: Yekela kum mfundisi ndimncede.

Zwilakhe: Let me help him pastor.

Indima 4, Umboniso 1:64

Act 4, Scene 1:64

Climax is also reached when Mzamo, Gugulethu's friend, is murdered by a boy. Gugulethu is devastated. He laments his friend's death:

Gugulethu: Liqalisile!! Liqalisile! Liyaduduma! Yahamb'intangam yandulela abaninzi... 
Gugulethu: It has started! It has started! It's thundering. My friend has gone before others...

Indima 4, Umboniso 1:65

Act 4, Scene 1:65

This is the first thunder that Gugulethu has been talking about. The climatic knot in this drama is tight, for it fastens the grip of fear that besets the audience.

\section{EPISODE 5: TURN OF EVENTS}

The crisis is now reached and there is a turning point in the plot which brings about a resolution. From this moment it is clear that the action will move towards its denouement. This episode focuses on NomaMpondomise.

NomaMpondomise leaves her parents after reading the sad news that Mzamo is murdered at Gugulethu's wedding. She cries:

NomaMpondomise: Yhoo! Yhoo! Thixo, kazi ndingumntu oyintoni na?

Yho-oo! Yho-o-! (Ulahla iphepha elila)

Indima 5, Umboniso 1:75

NomaMpondomise: Yhoo! Yhoo! God, what will become of me? Yhoo-o!

(She drops the paper, crying)

Act 5 , Scene 1:75

This tragic discovery, the cause of NomaMpondomise's misery, is referred to as tragic frustration. Her parents do not know what she is talking about.

NomaMpondomise is shocked by Gugulethu's wedding because he has promised to marry her, and it is because of his marriage proposal that NomaMpondomise has driven out the cattle. She goes to court to press charges against Gugulethu who has broken the promise.

Gugulethu goes to court where he meets his lover NomaMpondomise. He is found guilty. Zwilakhe pays for Gugulethu much against his (Gugulethu's) will. This action shows that 
Zwilakhe does feel guilty. Before the sentence, Gugulethu and NomaMpondomise kiss and she leaves to drown herself. Gugulethu is deeply disturbed by NomaMpondomise's death. He says:

Gugulethu: Awu, yini na le ntombi kaLangeni? Uyandishiya na kweli phakade? ... Liyaduduma! Liyaduduma, Lidlula nemiphefumlo. Buzani kubawo! Buzani kubawo! (emphasis)

Indima 5, Umboniso 2:82

Gugulethu: O! What is it now Langeni's daughter? Do you leave me in this world? ... It's thundering! It's thundering, it passes with people's souls. Ask father! Ask father! (emphasis)

Act 5, Scene 2:82

MaNyawuza, NomaMpondomise's mother dies upon hearing of her daughter's death. NomaMpondomise's death does not force Gugulethu to accept Thobeka as his wife. Instead matters complicate more and more. These deaths are unexpected and in striking circumstances.

\section{EPISODE 6: DENOUEMENT}

In this episode, overpowering force triumphs so that the course of events changes. The actions of characters change and the conflict approaches an end. The events in this episode of Buzani kubawo approach an end. The message that is being conveyed by Tamsanqa to the audience comes out clearly. During Gugulethu's absence Thobeka has three children. Gugulethu has left home to work in Umtata and he does not come back home. For this reason Gugulethu's father then sends Thobeka and the children to be with Gugulethu in Umtata. Gugulethu is shocked by this visit:

uGugulethu: Tyhini ngobani aba?

Gugulethu: O! no, who are these?

uThobeka: Sithi

Thobeka: It's us. 
uGugulethu: Thobeka!

Gugulethu: Thobeka!

uThobeka: Bhuti

Thobeka: Bhuti

uGugulethu: Uyaphi?

Gugulethu: Why are you here?

uThobeka: Ndize kuwe

Thobeka: I've come to you

UGugulethu: Uze kum uyandazi ndingubani? Ndiyini kuwe?

Gugulethu: You've come to me. Do you know me? What am I to you?

Indima 6, Umboniso 3:93

Act 6, Scene 3:93

Gugulethu leaves Thobeka and her children and when he comes back in the evening he decides to murder all of them. He goes to the police to be arrested for this murder. Gugulethu is arrested and he is taken to court to face the charges. He blames his father for all that happened. MaGaba commits suicide by drinking poison. Gugulethu gets a death sentence. Zwilakhe remains alive.

All the disaster which is taking place in this drama is caused by a clash of cultural values. This comes out clearly in the speech by the judge:

ljaji: Bantu abaNtsundu yifundeni ukusukela namhlanje into yokuba xa sizama ukuphelisa la masiko enu asinto yokuba siyanicaphukela, koko sizama ukunqanda amasikizi athi abe ziziqhamo zamasiko enu aphuthileyo athi akhokelele entshabalalweni. Qondani mhlophe boonozala ukuba uthando apho lukhoyo alunakho ukuthintelwa ... musan'ukucinga ukuba into eyayilungile kumaxesha amandulo isalungile nanamhlanje, amaxesha ayaguquguquka, izinto zonke zinamaxesha azo, "Lest one good custom should corrupt the world". 
Judge:Black people, as from today onwards you must learn that when we try to do away with your customs it is not that we hate you. We are trying to prevent tragic incidents, which are the fruit of your bad customs that lead to destruction. It should dawn in your minds, parents, that nothing can prevent love. Do not think that things, which used to work well in the olden days can still work nowadays. Times change and each and every time has its own values.

Act 6:102

The Judge shows that the basis of the unnecessary blood bath in this drama is the decision by parents to decide for their children in the issue of marriage.

\subsubsection{Analysis of the plot structure}

This drama can be divided into the following episodes:

(a) Zwilakhe and MaGaba's decision for Gugulethu to marry Thobeka.

(b) Paying of lobola by Zwilakhe and NomaMpondomise's acceptance of Gugulethu's proposal

(c) Marriage of Gugulethu and Mzamo's murder.

(d) NomaMpondomise's suicide.

(e) Murder of Thobeka and her children and sentencing of Gugulethu.

The author's plot is uncomplicated. This simple plot is not only devised to lure the readers to this drama. It is devised in this uncomplicated manner in order to suit the theme, that is, forced marriages and their consequences.

Having explored this drama, one is struck by strange developments in the plot. In Act 3, Scene 3, we are introduced to NomaMpondomise and her mother MaNyawuza. By this time Mcunukelwa, NomaMpondomise's husband-to-be has already paid lobola. NomaMpondomise does not love Mcunukelwa. She wants to marry Gugulethu. NomaMpondomise tells her mother that she is going to drive the lobola cattle out. This takes place at Engcolosi. NomaMpondomise boldly and defiantly informs her mother that she does not love the man they force her to marry to: 
uNomaMpondomise: $\quad$ Mama ndiyazikhupha ezi nkomo.

NomaMpondomise:

Mother I am driving out these cattle.

uMaNyawuza:

Ziphi iinkomo? (Esothuka)

MaNyawuza:

Which cattle? (shocked)

uNomaMpondomise:

Ezi zilobole mna.

NomaMpondomise:

My lobola cattle.

uMaNyawuza:

MaNyawuza:

uNomaMpondomise:

NomaMpondomise:
Yintoni kanye le uyithethayo?

What is it that you're saying?

Ndithi ndiyazikhupha ezi nkomo zilapha ebuhlanti, andiphambananga xa nditshoyo ndiphile qete. Kaloku qondani mhlophe andizange ndilithande kakade eli soka, nini enanyanzelisayo, ndisala mna.

I am saying that I am driving out the cattle which are in the kraal and when saying so, I am not mad, I know exactly what I'm doing. You should bare in mind that I have never loved this man, you forced me even though I was refusing.

Indima 3, Umboniso 3:51

Act 3, Scene 3:51

The above excerpt contains one assertion, namely NomaMpondomise is forced to marry the man she does not love. This act of driving out lobola cattle is for her the only way of telling her parents that she does not love her husband-to-be. Her mother, MaNyawuza, reminds her about the Xhosa custom that if a girl drives out lobola cattle because she does not love her husband-to-be, then she must tell the one she loves to pay lobola cattle thus replacing the rejected ones. MaNyawuza's problem is that some of the lobola cattle have already been used.

In her meeting with Mcunukelwa, NomaMpondomise tells him to fetch his cattle from her home. She does not want to be asked about what the problem could be because by so doing then one will be crying over spilt milk. Mcunukelwa begs NomaMpondomise to 
change her mind. What one gathers from NomaMpondomise's response to Mcunukelwa is that she cannot commit herself to someone whom she does not love because love is one of the most important ingredients of marriage.

Worth noting is also Zwilakhe's response in church when Gugulethu refuses to say the marriage vows. At first Gugulethu remains silent, but later on when instructed by the presiding priest to repeat the marriage vows after him he says "ask father" (Buzani kubawo). The presiding priest is shocked and then decides to call the father of the bridegroom, Zwilakhe. Zwilakhe tells the priest to ignore Gugulethu's actions and continue with the proceedings. He promises to inform the priest about everything concerning Gugulethu after the wedding ceremony:

uZwilakhe: Hayi mfundisi qhuba wena ungayinanzi yonke into ayenzayo. Lo mntu wena kwezi ntsuku usuke wanendawo yokungathi uthe phithi. Inkcazelo ezeleyo ndingabuya ndikunike xa sisobabini.

Indima 4, Umboniso 1:65

Zwilakhe: No, priest, continue and ignore all that he is doing. This young man has been a bit disturbed lately. I will give you the full explanation when the two of us are alone.

Act 4, Scene 1:65

The priest refuses to continue because of Gugulethu's silence. Zwilakhe then persuades his son not to disappoint him and immediately thereafter instructs the priest to continue with his work. Gugulethu is not co-operative at all and he keeps on saying, "ask father". He does not even want to sign the marriage register because he pretends to be injured. Zwilakhe wants to sign the register himself which is very strange. Tamsanqa, the playwright, forces Gugulethu to reluctantly abide by his parent's demands because he wants to prove that customs can be oppressive as well as the dangerous consequences of forced marriages. He demonstrates that as the heir of Zwilakhe, Gugulethu is forced and bound by tradition to follow his society's customs. If Gugulethu does not obey his father, then he will not be able to enforce and instill the values of his people. The above issues are what the drama seems to emphasize. 
Another interesting, yet strange development is that of Mzamo's murder. The misunderstanding between Nimrod and Mzamo leads to Mzamo's death. This is surprising. Why does the playwright kill Mzamo? Perhaps one may say it is the foreshadowing of what will happen later. Surely this is not necessary at all. Tamsanqa has employed right from the beginning of this drama certain symbols which are mainly concerned with the foreshadowing of conflict and death.

Thobeka's way of reasoning and behaviour is unusual. How could she go to Gugulethu in Umtata, knowing fully well that Gugulethu does not love her? How could she go to Gugulethu with children begotten from another man? One also wonders why Gugulethu kills the innocent children. He is not supposed to be jealous because he does not love Thobeka.

Good symbolism is a striking feature in Buzani kubawo. In the broadest sense, a symbol is anything which signifies something else. Grey (1984:204) says that a symbol is:

... something which represents something else (often an idea or quality) by analogy or association.

Gill (1985) as quoted by Tshikovhi (1997:111) explains symbolism clearly when she suggests that:

... a symbol is a word that stands for, or points to, a reality beyond itself, sunrise is often used as a symbol for a new beginning.

The play opens with expository events and symbolism depicting the conflict created by a forced marriage. Unlike in the other dramas under study, this forced marriage is an issue between father and son. Gugulethu is forced to marry Thobeka who is his parents' choice. On the other hand, Gugulethu's lover NomaMpondomise is forced to marry Mcunukelwa.

Careful attention to the manner in which the plot is punctuated and contradicted by symbolism reveals that the drama raises itself beyond the literal description of action. For instance, Tamsanqa admirably opens his drama with a song sung by Nozipho and this song as already been said, hints at future and impending unpleasant events. One of those events is the total destruction of Gugulethu. Tamsanqa aims at exposing the dangers of 
forced marriages and in the process he kills one of the cornerstones of drama, that is suspense. According to Esslin (1976:43) suspense is that element of a drama which makes the audience feel tense, which makes them look forward to the next scene or event in suspenseful expectation. As such it is then the source of interest in a drama. Furthermore, he elaborates, drama which keeps the audience "rooted to their seats" must necessarily have well-developed lines of tension. Tamsanqa's character, Nozipho narrates her dream which is obviously about what will happen to Gugulethu later on in the book.

The dream prepares the reader for the culture clash between Gugulethu, who represents the African community which endorses modern values, and Zwilakhe, who is portrayed as representing the African community which romanticize pre-colonial culture. If this dream is interpreted as a pointer to what will happen later in this drama, then it is not necessary because this has already been gathered from the expositional information. In fact it tells us exactly what will happen to Gugulethu later on, thus killing the reader's suspense. The smoke symbol which creates an atmosphere of uneasiness, discomfort and suffering is also presented by the playwright. For instance, from the outset Nozipho is introduced sitting alone in a hut full of smoke. All these symbols contribute considerably towards creating an atmosphere of sombre dreariness, of coming trouble and foreboding doom.

Tamsanqa uses one of the crucial modes of character delineation in his play, namely, the naming technique. In some cases names identify characters' attributes. Sirayi (1993:93) informs us that:

Naming as a literary technique is the oldest which is culture bound in the African context.

He explains further, "in various cultures the proper name suggests the formation of personality, and such names sometimes indicate character types".

Zwilakhe's name is indicative of his character. He believes in his own word and he rejects any type of advice. In English, Zwilakhe means "his own word."

Symbolism in this drama has been handled with commendable skill because certain ideas and insights are couched in this magnificent imagery. The author's sparks of creative 
faculty are evident in his work. They are often the art that shapes our appreciation of the beauties of the drama.

However, there is a serious deficiency in the structure of this drama. We note a serious gap between Act 5 Scene I and Act 6 Scene I. Tamsanqa begins Act 6 Scene I by saying:

Iminyaka lishumi linesibini uNomaMpondomise ezeyelisele

It's after twelve years, NomaMpondomise has drowned herself.

Indima 5, Umboniso 1:50

Act 5, Scene 1:50

Perhaps this period gives enough chance for Thobeka to conceive and get children. Nevertheless, this does not deter one from regarding it as a serious deficiency. The basis of tragedy in Buzani kubawo is the decision by parents to decide for their children in the marriage issue.

\subsubsection{UDike noCikizwa (A.M. Mmango, 1963)}

\subsubsection{Episodes}

The plot structure of uDike noCikizwa can be divided into five sub-episodes or phases. Some of these episodes do take account of the way in which events are related to each other and their dramatic effect. Others are not arranged according to the chronological order. There are also two main sub-plots or phases.

\section{EPISODE 1}

In episode one, which is the introduction, we observe the love affair of Dike and Cikizwa and the arrangements for a forced marriage between Mjongwa and Cikizwa. The opening scene spreads out from our interest in what is being said by Cikizwa in her letter to her lover, Dike. Cikizwa minces no words in venting her deep-seated frustration about her father who forces her to marry Mjongwa Ngqike whom she does not love. She cries out: 
Dike wam

Kubi ukuphila kweli lizwe - ilizwe lamasiko, lezithethe nemithetho, izinto ezithi unenyama negazi nengqondo nje zikwenze ufane nesigodo somthi olinde ukubaswa.

Ndisitsho nje ndiva intlungu yokuthobela umthetho katata - ondinyanzela ukuba manditshate noMjongwa Ngqike, umfana waseMahlungulu.

Onke amalinge am okuzama ukubonisa utata ukuba andifuni ukutshata nalo mfana awe phantsi,

Ndithi mandikwazise le nto, Sthandwa kuba apha emhlabeni andazi bomi bumnandi njengobabathandanayo, ndaye andiboni mfana ndifana naye ngaphandle kwakho Dike wam.

Indima I, Umboniso I:2

O my Dike-

It is bad to live in this world - a world of custom, of tradition, of laws, things which although you have flesh, blood and brains, make you look like dead wood ready to make fire.

I say this because I feel the pain of respecting my father's law, a law which deprives me of my humanity and makes me feel like a reared sheep. My father's strict law forces me to marry Mjongwa Ngqike... All attempts to show father that I do not want to marry this young man have failed...

I feel I must inform you my love, because on this earth there is no joyful life like the life of loved ones, and moreover I see no other man from whom I can be parted by death, besides you, my Dike.

Act I, Scene I:2

As suggested by the tense mood of this letter, Cikizwa lampoons the patriarchal attitude towards women and condemns certain traditional African systems for their marginalization of women. She mentions her father Sando, who is the epitome of autocratic attitude towards women. Sando, Cikizwa's father sees Cikizwa as a subordinate, a woman who 
should be silent in the presence of men as he forces her to marry someone whom she does not love.

Looking ahead, the prospect of her life makes her feel as if she were buried alive. This is inevitably exposed in the words she uses in her letter to Dike. Cikizwa's words depict the strained relationship between her and the rest of the community. The emotive language in her letter to Dike creates a sombre atmosphere. Clearly, the author resents the traditional system under which she lives. She even forgets to bring the two characters, Dike and Cikizwa together. In a way, this technique does spoil the exposition of her plot structure.

What transpires from Cikizwa's letter is that the playwright feels strongly about the custom that forces women to obey their fathers under all circumstances. The punchy language of Cikizwa's letter is indicative of the profound sense of alienation that Mmango exposes in Sando, Cikizwa's father. The above extract from Cikizwa's letter is a thread by which the developments in the play find coherence. It performs the function of predicting what is to come but in such a manner that one is filled with expectancy yet still left ignorant of what exactly is going to happen.

Having received Cikizwa's letter, Dike responds in a very defiant manner. He is confident that there is nothing that can separate him from Cikizwa, his lover. His lover is to him the most perfect of all women. Dike is white to the lips when he reads what is being said by Cikizwa in her letter. The following passage marks Dike's seething rage and frustration which will lead to violent confrontations.

uDike: (esonga incwadi)

O! Eli lizwe lentobeko mthetho! Ngaba kukho mthetho na? Ongandahlula noCikizwa? O! Ukuba kunganjalo. Ingaba asililo lizwe le nto. Hayi, akusayi kuba njalo! Ukuba uyohluthwa nam ndiza kuba yingonyama.

Indima I, Umboniso 1:3

Dike: (folding a letter)

$\mathrm{O}$ this world of abiding by the law! Is there any custom, is there any law that can separate me from Cikizwa? O! If that is the case, this world is no good. No, it won't be like that! If she is taken away from me, I'll be a lion also. 
The tension is further apparent in Dike's words. Anger and resistance is contained in the ensuing dialogue. The sentence: "Nam ndiya kuba yingonyama" (I'll be a lion also) displays anger and frustration. Dike vehemently objects to surrendering to the oppressive customs and traditions. He is determined not to play with love at all. He laments his fate:

Ngaba kukho mthetho na? Ongandahlula noCikizwa?

Indima I, Umboniso 1:3

Is there any law that can separate me from Cikizwa?

Act I, Scene 1:3

At home, Cikizwa is not happy. She is sickly. Cikizwa's two aunts, Nomatiletile and Nomazala are aware that Cikizwa is against her forced marriage. Nomatiletile tries to draw the attention of Nomazala and Nojoyini to the issue of changing times where things like forced marriages can no longer be practiced. The other aunt, Nomazala does not share her views. She strongly disagrees with Nomatiletile. Nomatiletile tells Sando that by not allowing Cikizwa to think and make her own decisions and choices then he is making her a slave. Sando reacts violently to Nomatiletile's advice. He shows his patriarchal attitude towards Nomatiletile by telling her angrily that he has done absolutely nothing wrong. He believes that the husband is the head of the family, and as such, he cannot be challenged. Sando says:

Sando: (ngomsindo)

Andenzanga nto inxaxhileyo emthethweni. Yimfanelo yomzali emntwaneni ukuba amkhulise, amenzele onke amalungelo afanelekileyo umntwana wakhe. Ngaba ndinkqangiswa ngantoni ngoku xa ndilungiselela umntwana wam, ndimakhela ikhaya? Andithi ikhaya lomntwana oyintombazana lisekwendeni? Wena unga lo mntwana wam angaphalala ndakufa?

Indima I, Umboniso 2:7

Sando: (angrily)

I've done absolutely nothing wrong in the law. It's the father's right that he does everything for the child in bringing her up. Why then am I being confronted when trying to build a home for my 
child? Is a girl's home not in marriage? And you, do you wish that this child can be destroyed socially when I pass away?

Act I, Scene 2:7

As indicative of her name, Nomatiletile ("different types of plans") tries different types of approaches to persuade and advise Sando on this issue of a forced marriage. Sando does not want to listen. He informs Nomatiletile that she is wasting her time because he cannot be told by a child what to do. When Nomatiletile responds by warning him that he will remember her one day, it is evident that these words are uttered by a hurt and frustrated human being. Sando does not heed Nomatiletile's advices because she is a woman.

Cikizwa is confronted by her aunt Nomazala for not agreeing to marry when her father is trying to build a home for her. Cikizwa responds by saying that she believes in love and not riches of a home because apparently Mjongwa is a rich farmer. Nojoyini, Cikizwa's mother, informs Sando and Nomatiletile about Cikizwa's health. Once more, Nomatiletile tries to warn Sando about dangers of this forced marriage. Cikizwa pretends to be ill thus trying to run away from the marriage date. Cikizwa wants a plan to free herself from this predicament. She is a weak character who is dependent on Dike for the solution of her problem.

Mmango is so pre-occupied with the critical perspective in marking the forced marriage practice as oppressive that she fails to arrange her events chronologically and, instead, jumps to Nonjoli's one-sided love for Mjongwa and thereafter her suicide. Cikizwa shares her problems with Nonjoli. She informs Nonjoli that she will marry Mjongwa only to obey her father's law. By so doing, she says she will be blessed and that is a sign of good behaviour. This implies that she does not love Mjongwa and Nonjoli is taken aback by this attitude. Cikizwa says to Nonjoli:

Cikizwa: Kaloku sis'Nonjoli, wumbi sukuba esenza imfanelo, ethobela umthetho wabazali bakhe. Ngaphezu koko ke andithi thina bantwana sikhulela phantsi kwemithetho yabazali, kuyimfanelo ke ngoko ukuba siyithobele khon'ukuze sifumane amathamsanqa neentsikelelo? 
Nonjoli: Lilonke ke utheth'ukuthi uza kutshata noMjongwa ngokuThobel'umthetho wabazali bakho?

Cikizwa: Ewe ngokuba ndicing'ukuba ukuthobel' umthetho wabazali yinyaniso.

Indima I, Umboniso V:14

Cikizwa: By the way sis'Nonjoli, one may be following an obligation, obeying the authority of one's parents and besides don't we as children grow up under the tutelage of our parents and, therefore, is it not an obligation to obey them so that we may be blessed with good fortune?

Nonjoli: $\quad$ So in all, do you mean that you are going to marry Mjongwa because you must obey your parents' wishes?

Cikizwa: Yes... because I think that to obey parent's wishes is the right thing to do.

Nonjoli advises Cikizwa not to say marriage vows in church. By so doing, Nonjoli explains, the wedding cannot go on at all. Unaware of Nonjoli's hidden agenda, Cikizwa gets excited because the priest will not marry her to Mjongwa:

Cikizwa: Kwo! Undikhulule ntombi kaFadalele ngeli cebiso undithwese lona. Ngoku andisayi kuzikhathaza ngale nto, ndiza kusebenzisa icebiso lakho ndahlukane noMjongwa kuba andizi kuvuma ukutshata noMjongwa ndingamfuni.

Indima I, Umboniso 4:15

Cikizwa: You have liberated me, Fadalele's daughter, with your advice. Now I shall not worry about this. I am going to use your advice and have nothing to do with Mjongwa, because I shall refuse to marry Mjongwa as I do not want him. 
Gando, Dike's neighbour arrives at Dike's place while Dike is still deep in thought about his problem with Cikizwa. He does not understand why Dike bothers himself that much about Cikizwa when there are so many girls out there. Gando says bad things about women. He strongly believes that they cannot be trusted. Girls, he says, always have hidden agendas. They argue about this, Dike informing Gando that Cikizwa is different from other women.

Once more we are introduced to Nonjoli on her way to the Mhlabamnyama shop. She meets Nonzuzo who is Mjongwa's cousin. Nonjoli informs Nonzuzo about Cikizwa who does not want to marry her cousin,Mjongwa, because of his stupidity. Nonjoli indicates to Nonzuzo that she herself loves Mjongwa and as such she can look after him well and would not like to see him suffering. Nonzuzo shares Nonjoli's concerns that Mjongwa must love someone who admires and respects him and that person is apparently Nonjoli.

The playwright demonstrates Nonjoli's one-sided love for Mjongwa. Nonzuzo visits Mjongwa in his place. She asks if Mjongwa loves Cikizwa to which Mjongwa responds that they were never in love. Mjongwa is irritated by Nonjoli's conversation and tells her that he had never loved anyone and he never will. Nonjoli is devastated and she feels humiliated because it is evident that Mjongwa loves Cikizwa.

Sando's action of reading Cikizwa's letter from Dike conducts the plot further. He takes the letter by force from Nomalungelo, Cikizwa's sister. Having heard about this incident, Cikizwa is devastated because she knows fully well that their plans will now be thwarted. After having read the letter, Sando does not regard his daughter as a human being because she betrayed him. He says:

Sando: $\quad$ Oo! Kanti le njakazi iyazigulisa, sokhe sibone

Indima 2, Umboniso 4:27

Sando: Indeed! So this bitch is feigning illness, we shall see.

Act 2, Scene 4:27

Having finished reading the letter, Sando curses Dike. It is now clear in his mind that Dike is the one who influences Cikizwa not to marry Mjongwa. He is determined to kill Dike who has come between himself and his daughter. Sando says: 
Sando: $\quad$...ngokwenene uza kufa wahlukane nomntwana wam.

Ukuba ke gqwirhandini wamdlisela ukuba aze endele nasengcwabeni lakho uya kuba uyandahlula ndaye nam ndiya kumhlamba Indima 2, Umboniso 4:27

Sando: $\quad \ldots$ indeed you are going to die and leave my child alone. If you poisoned her, you wizard, that she might marry you even when you are dead, you will cast me out and I shall also cast her out.

Act 2, Scene 4:27

Sando calls Dike a dog. He believes that it is only when the stumbling block has been removed that all his household problems affecting Cikizwa will be solved. He says:

Sando: $\quad$ Yakuba ishexile le nja umntwana wam uya kuvuleka iindlebe namehlo aqiqe, aqonde, eve, ade abunakane ubutyhakala bokwala ukwenza intando yam ndimzele. Yona le inja ayisayi kuphinda ilahlekise abantwana babantu igqibelisile.

Indima 3, Umboniso 2:31

Sando: $\quad$ After this dog has been removed, my child's eyes and ears will open, she will also realize the stupidity of refusing to obey her father's will. As for this dog, he will never deceive any other people's children, this is his last time.

Act 3, Scene 2:31

The contents of the letter written by Dike to Cikizwa run thus:

Akukho siko,

Akukho sithethe

Akukho mthetho,

Hayi-, akukho nakufa

Kungasahlulayo thina sobabini! 
There is no custom,

There is no tradition

There is no law

No, - not even death

Can separate the two of us!

Act 3, Scene 4:27

Not only is Sando angered by his daughter's disobiedience, but he is also worried because he cannot afford to lose lobola cattle for his enrichment:

Sando: $\quad$ Ndiza kuphulukana neshumi elinesihlanu leenkomo amashumi amabini eegusha nehashe ngenxa yesi sidenge

Indima VI, Umboniso 11:74

Sando: I am going to lose fifteen head of cattle, twenty sheep and one horse because of this fool.

Act VI, Scene 11:74

\section{EPISODE 2: THE MOTORIC MOMENT}

Episode 2 is the motoric moment. It entails Sando's arrangements for the murder of Dike after the discovery of his letter. Sando goes to Bhalasi school and meets the principal of the school, Mr Mdendo. He pretends to be visiting the school as an ex-student and as such he is impressed with all the improvement. Mr Mdendo takes Sando around the school and introduces him to all the teachers, including Dike. Sando is pleased to meet him in person at last. One of the lady teachers tells Sando that Cikizwa is her friend. Sando says that Cikizwa is his niece.

Dike is not happy with the way Sando decided to hide his identity at school. He suspects that Sando has a hidden agenda.

All along, Dike is not aware that Sando intercepted Cikizwa's letter and as such Cikizwa knows nothing about their appointment at Qumbu. Dike travels to the bus stop to meet Cikizwa who fails to arrive. He thinks that maybe Cikizwa decided to go to Ntsimbi's place for their appointment. 
Dike is off to Ntsimbi's place. Sando arrives at Qumbu on horseback. He does not see Dike and then he remembers that the appointment is at Ntsimbi's place. He decides not to go to Ntsimbi because he does not want to be seen by Dike in town. He does not want to abort his plans. He leaves the horse in the stable and decides to go around in town.

Dike arrives at Ntsimbi's place and learns that Cikizwa did not arrive. He tells Ntsimbi about the dangerous situation in which their affair is. When informed about Cikizwa's forced marriage, Ntsimbi suggests that Cikizwa must not take the marriage vows. Dike informs Ntsimbi about Sando's visit to their school which he is not happy about. He tells him everything and that he does not trust Sando. Dike decides to go to Bhalasi not knowing that his movements are being monitored by Sando.

By now, in Act IV, Scene 3, the conflict in the development of the plot has reached its boiling point or peak. Sando encounters Dike and provokes him. The emotions are intensified and suspense is sustained, for example, when Sando threatens Dike:

Sando: $\quad$ Kusuka kuthi nyaka ndakukubona

Sando: I become extremely upset when I see you.

Dike: $\quad$ Ngokuba ndenzeni Bawo?

Dike What have I done, father?

Sando: $\quad$ Uyabuza mene-menendini?

Sando: You ask, you crook?

Dike: $\quad$ Ndifanele ukubuza Bawo andazi sono ndisenzileyo kuwe

Dike It is because I do not know what sin I have committed against you, father.

Sando: $\quad$ Uyasazi isono sakho njandini

Sando: $\quad$ You know your sin, you dog

Dike: $\quad$ Noko iyandothusa Bawo into yokuthi mhla uqala ukuthetha nam uxabane ngaphandle kwesizathu 
Dike: I am surprised, Father, by the fact that you talk to me like this on the first day we meet and quarrel with me without a reason Indima IV, Umboniso III:32 Act IV, Scene III:32

The sad part of the whole scenario is that Dike, who politely and friendly apologizes, is murdered by the cruel Sando. To prove that Sando's heart is evil, he is not even touched by the following words by Dike:

Ndicela uxolo Bawo. Umntu xa ethukela sukuba efuna umsebenzi wegazi endingazimisele kuwo ngoku

Indima IV, Umboniso III:33

I apologize father. When a person swears he is usually challenging one to a fight and I am not prepared for it.

Act IV, Scene III:33

In Sando's act action piles upon action to bring matters to a head. In Dike's words, one sees that he is loyal to tradition in certain important ways. For instance, Sando insults Dike, but Dike still politely calls Sando Bawo (father). Dike is a peace loving character. He pleads with Sando but unfortunately his pleas fall on evil ears:

Bawo wam, masakhe ubuntu obusulungekileyo ngemvisiswano. Ixabiso lomntu alikho ekubeni abe ngumthombo wenzuzo, lisekubeni abe ngumntu ebantwini.

Indima IV, Umboniso III:33

My father, let us build pure humanness by creating harmony. A person's worth is not measured by material going but rather in his/her dignity among other people.

Act IV, Scene III:33

Sando is so cruel and evil that he even swears at Dike's corpse. He says: 


\section{EPISODE 3: COMPLICATION}

Episode 3, which is complication, entails the love of Nonjoli for Mjongwa and her suicide. In scene IV Nonjoli meets Mjongwa in the Mhlabamnyama shop. The playwright brings in this devious character Nonjoli who is still fighting for Mjongwa who does not love her.

Mjongwa tells Nonjoli that he is interested only in farming and he does not love anyone. Nonjoli tries to hug Mjongwa and he refuses. Nonjoli is humiliated. Mjongwa bellows:

Andiyifuni le nto uyenzayo

I do not want what you're doing.

Indima III, Umboniso IV:27

Act III, Scene IV:27

Nonjoli is devastated. Now she thinks that Cikizwa and Mjongwa love each other and that they are just fooling people by saying that they are not interested in each other. She vows to remove Cikizwa whom she thinks is the stumbling block to her happiness. Nonjoli says:

UMjongwa akanamdla kum unomdla kuCikizwa. NoCikizwa unomdla kuMjongwa. UMjongwa uvaleke iindlebe namehlo bubuhle bukaCikizwa. Xa kunjalo ke makashenxe uCikizwa.

Indima III, Umboniso IV:28

Mjongwa is not interested in me. He is interested in Cikizwa. Even Cikizwa is interested in Mjongwa. Mjongwa's eyes and ears are closed by Cikizwa's beauty. If that is the case, then Cikizwa must go.

Act III, Scene IV:28

Nonjoli plans to poison Cikizwa in order to get Mjongwa. Her plans are exposed and she decides to commit suicide because she cannot stand humiliation.

Nonjoli's evil plans are laid out clearly in her soliloquy so readers do not have to deduce anything from what she says. This makes the play flat. Nonjoli says: 
UCikizwa mandimenzele isiselo aya kuthi akusisela angaliboni xa litshonayo namhlanje! ... Akungekhe undishiyisele kuMjongwa uze uphile! Yifa nobuhle bakho.

Indima V, Umboniso 1:40)

I must prepare a drink for her, which will prevent her from seeing the sunset today! ... You cannot win Mjongwa's love and live. You must die with your beauty!

Act V, Scene 1:40

\section{EPISODE 4: CLIMAX}

Episode 4 is the climax. On the wedding day in church, Cikizwa refuses to accept the marriage vows. At this stage she is not aware that her beloved Dike is killed by her father. Sando boasts about the way he murdered Dike whom he calls "a dog" when Cikizwa refuses to sign the marriage vows. He expresses his feelings:

Andinanxaxheba! Ndiyibulele ngezandla zam loo nja ngokulahlekisa umntwana wam! Nguban'othethayo?

Indima VI, Umboniso II:73

I did not assist! I killed that dog with my hands because he misled my child.

Who says what?

Act VI, Scene II:73

As the priest is busy officiating, Ntsimbi informs the congregation that Cikizwa and Mjongwa cannot be allowed to tie the knot, because Cikizwa does not love Mjongwa. The priest enquires from the elders if they know Ntsimbi and they explain that they do not know him and they do not think he is serious about what he said.

The priest decides to continue with his work. He reprimands Ntsimbi for his behaviour in such an occasion. Ntsimbi insists on what he wants to say to the congregation. Sando becomes angry and approaches Ntsimbi for a fight. One of the elders decides to diffuse the volatile situation. The priest continues with the marriage vows. Mjongwa does take his marriage vows. Cikizwa on her side says the opposite of what the priest says. She says that there is something that prohibits her from marrying Mjongwa. She refuses to take the 
marriage vows because she does not want to lie. Mjongwa instructs the priest to continue with his service because their parents have agreed long ago that the two must get married. Cikizwa continues refusing the marriage vows. Sando wonders what the problem with Cikizwa might be. Cikizwa tells the priest that she never loved Mjongwa. Mjongwa says that he had never loved anyone and they came to the church because of their parents' agreement.

Sando forces the priest to continue with his work and the priest refuses because their future is at stake. Sando boasts that he killed the person who is responsible for his daughter not taking the marriage vows. That person is Dike.

The detective, Mr Lola who hears what is being said by Sando decides to arrest him because he is the suspect in Dike's murder case as suggested by what he says in church. Cikizwa collapses. Sando points a gun at Lola. Lola tries to forcefully take the gun from Sando and Sando shoots. He shoots Mjongwa accidentally and Mjongwa dies.

The three women Nobangile, Nojongile and Nofezile are on their way home from the Bhelekence Methodist Church. They are still shocked about the happenings at the wedding. They argue about the advantages and the disadvantages of education. Nobangile asserts that there is nothing wrong with education. Education is the light of the world.

These three women argue about what was happening in church. Apparently Nojongile knows the whole story and she narrates it to them without mentioning the damage to the affected people. For instance, she calls Cikizwa "Nosingaye". Nofezile is shocked and Nojongile warns them not to tell anyone about it. They now change the topic and discuss about who are gossipers these days. Nojongile also remarks about men to whom you cannot air your views anyhow, because one can be thrashed by them. These women believe that when one talks with a man then one should be tricky and use one's brains because men are physically stronger.

In Scene 4, we see Ngwemla and Siba next to Sando's kraal. They are confused by Sando's arrest whilst they are still shocked by Cikizwa's behaviour. Ngwemla feels that the modern weddings are not right at all. Siba feels that there is nothing wrong with the 
modern weddings, the problem lies with parents who do not make sure that their children do agree with each other on marriage. Siba says:

Akukho nto yoniwe ngumtshato wasecaweni impazamo ibe kubazali ngokungaqinisekisi kwasentlandlolo ukuba abantwana bayavisisana na. Umtshato wasecaweni mna ndiwufanisa nesihombiso entweni eyalukwayo..

Indima 6, Umboniso 4:57

There is nothing wrong with the church wedding, the mistake is with parents who do not make sure from the onset if their children have agreed with each other or not. I see the church wedding as a decoration in something which is knitted.

Act 6, Scene 4:57

Siba believes that things are spoilt by ignoring the change of times.

In Scene 5, Nomazala is with Cikizwa in her room. Cikizwa is now conscious. Nomazala reprimands Cikizwa for being a disgrace to the Ntando family by her actions in church. Cikizwa tells Nomazala that if she told lies then she would have been ashamed of herself. Nomazala feels that Cikizwa embarrassed Sando in full view of the congregation. Nomazala leaves Cikizwa alone.

\section{EPISODE 5: DENOUEMENT}

Episode 5 is the denouement. It is about Cikizwa's suicide. In her soliloquy Cikizwa says that she cannot live without Dike and as such she wants to die. She looks for a bottle containing poison. She goes to Luqhoshile and sees a dead dog as well as Nonjoli's bottle of poison. This poison is the one used by Nonjoli in her devious plan to kill Cikizwa. She drinks the poison and then writes a suicide note.

Cikizwa ties the letter at the neck of the bottle, then lies down on the bed and dies. Her body is discovered by Nojoyini, Nomazala and Nomatiletile. Ngwemla and Siba are summoned and they see the body as well as the suicide note. In her suicide note, Cikizwa wants to be buried next to Dike. Nomazala regrets that Cikizwa was forced to marry against her will, but it is too late for such regrets. 
In Scene VI, Ntsimbi, Gando and Ntando relatives have gathered in the graveyard at Bhalasi. In his speech, Ntsimbi explains that people seem not to learn from their mistakes because after each and every incident that could be stopped, people are still stubborn. He warns people to stop looking to their children in order to enrich themselves. He says that people are greedy and in the process they even forget about what their customs really require. Gando praises Cikizwa for speaking the truth, because she was always telling people about the way she loved Dike. He summarizes his speech by saying:

Apha kulele uCikizwa Ntando, intombi entliziyonye.

Indima 6, Umboniso 6:60

Here lies Cikizwa Ntando, a girl with one heart.

Act 6, Scene 6:60

In Mmango's drama, there are two main sub-plots or phases. The first one is that of Dike, Cikizwa and Sando, including the death of Dike. The second one is that of Nonjoli, Mjongwa, Cikizwa and Sando, including the death of the first three and the arrest of Sando.

\subsubsection{Analysis of plot structure}

A critical analysis of uDike noCikizwa can be examined according to the following phases:

a) The abuse of Cikizwa by her father Sando who forces her to marry someone she does not love. Cikizwa's love is Dike. She pretends to be ill in order to extend the days, before marriage.

b) Nomatiletile's support for Cikizwa and her warnings about the consequences of his action during modern times.

c) Cikizwa and Dike's plan to fight against Sando. They plan to thwart Sando's actions.

d) Cikizwa finds herself in a dilemma because she feels obliged to respect her father and her tradition. At the same time she wants to defend her ideas about true love. She is advised by Nonjoli not to say vows in church. Nonjoli drinks poison because her dirty plan to kill Cikizwa is discovered. She is punished for her evil deeds. 
e) Sando discovers that Cikizwa has other interests. He intercepts a letter from Dike. The letter makes Sando a lion as suggested by Dike. Sando prepares to kill Dike. He hopes that Cikizwa will be reconciled to the idea of marrying Mjongwa.

f) The crisis between father and daughter occurs in church when Cikizwa refuses to take the vows and declares in public her reasons for not taking vows. She does not know that Dike is killed. Sando declares in anger that he has removed the obstacle.

g) Cikizwa commits suicide. Sando is arrested as a suspect for Dike's death. Mjongwa is killed by a stray bullet from Sando who resists arrest by Lola.

The fact that the author resents the traditional system under which she lives does affect her play's plot structure. It is clear that she has a grudge against laws which force women to live for other people's needs. From the onset, we are introduced to Dike and Cikizwa who are already frustrated by the country of oppressive customs and traditions. This is depicted in their emotive language in their letters, which create a sombre atmosphere.

The letter runs thus:

Dike wam

Kubi ukuphila kweli lizwe-ilizwe lamasiko, lezithethe nemithetho, izinto ezithi unenyama negazi nengqondo nje zikwenze ufane nesigodo somthi olinde ukubaswa. Ndisitsho nje ndiva intlungu yokuthobela umthetho katata umthetho ondiphanga bonk'ubuntu bam, undenze ndibe yigusha efuyiweyo

Indima I, Umboniso 2:10

\section{O my Dike-}

It is painful to live in this world of customs, traditions and laws, things which though you have flesh and blood and brains, make you an inanimate object like a log of wood that is ready to make fire. I say so because I feel the pain of obeying my father's authority, an authority that deprives me of all my humanity and makes me a reared sheep.

Act I, Scene 2:10

What transpires from Dike and Cikizwa's planned forced marriages is that the author feels strongly about the custom that forces women to obey their father under all circumstances. The love affair of Dike and Cikizwa is revealed as one of purity and ideal. They never 
meet, but only write letters. Their desperate wish and commitment to each other are revealed through the utterances they make in their letters. This unexpected behaviour of the two characters who are portrayed to be head over heels in love with each other and yet do not meet is an indication of a poor plot structure. The author is so pre-occupied with injustices against women that she even forgets to bring the two characters together.

Dike knew about the forced marriage from the beginning. Having received Cikizwa's letter, he utters the following words:

UDike: Ol Eli lizwe lentobeko mthetho!

Ngaba kukho siko na?

Ngaba kukho sithethe na?

Ngaba kukho mthetho na?

Ongandahlula noCikizwa?

O! Ukuba kunganjalo ingaba asililo lizwe le nto. Hayi, akusayi kuba njalo! Ukuba uyohluthwa kum nam ndiya kuba yingonyama

Indima I, Umboniso I:2

Dike: $\quad$ I This world of abiding by rules!

Is there any custom?

Is there any tradition?

Is there any law?

That can separate me from Cikizwa?

O! If that is the case. This is perhaps no world. No, let it not be so! If she is separated from me, I will be a lion too.

Act I, Scene I:2

One wonders why Dike did not begin his own arrangements for lobola with Sando.

In the phase on Sando's arrangements for the murder of Dike after the discovery of his letter, the playwrite has orchestrated her conflict very well. We see the conflict developing from the incompatibility of the characters' motives. The different actions of the characters and the possibility of conflict between them creates tension in the drama. The tension between Sando on the one hand and Dike and Cikizwa on the other hand, creates tension which eventually culminates in a final confrontational scene. 
Cikizwa and Dike's plan to fight against and thwart his actions is an important ingredient of conflict. Sando intercepts Cikizwa's letter from Dike which runs thus:

Kumiselekile kusikelelekile ukuba siphile sobabini, size sife sobabini Siseluthandweni.

Indima 2, Umboniso 2:27

It is given and blessed that we live together and die together in love.

Act 2, Scene 2:27

Sando becomes angry after reading the letter because it answers some of his unanswered questions, namely that of Cikizwa's attitude at the idea of the planned forced marriage. The author gets the attention of readers by creating such moments filled with tension between these characters, Cikizwa, Dike and Sando. He increases the level of tension between them gradually. It transpires from the letter also that Cikizwa was pretending to be ill in order to delay the wedding ceremony. Cikizwa and Dike make an appointment to meet at Mr Ntsimbi's place at Qumbu in order to solve their problem. Sando vows:

Oo! Kanti le njakazi iyazigulisa? Sokhe sibone

Indima 2, Umboniso 3:18

$\mathrm{O}$, so this bitch is pretending to be sick? We'll see.

Act 2, Scene 3:18

Sando decides to kill Dike. It is really not necessary to kill Dike because firstly Cikizwa's love for him has been illustrated as very high such that nothing can change it. Secondly, Mjongwa loves nobody and definitely not Cikizwa. Mjongwa says to Nonjoli:

Mna andizange ndimthande omny'umntu ndaye ndingasayi kuze ndithande mntu. Indima 3, Umboniso 4:27

I have never loved anyone and I never will love anyone.

Act 3, Scene 4:27

Thirdly, the lobola cattle are many and Sando could have got other lobola cattle from Dike. A fourth point is that Cikizwa is not Sando's only daughter. He could have obtained lobola for which he is so greedy from their marriages as well. 
The death of Mjongwa is unmotivated. He was a non-person in the whole drama and he was not even a victim. He agreed with the marriage and was even of the opinion that it will be good. Mjongwa explains to his sister Nonzuzo:

Ewe eyakho eyakhiwa ngothando ayinakuma kakuhle, kodwa le yakhiwa ngemvano nangemvumelwano yabazali iza kuma

Indima 2, Umboniso 3:16

Yes, yours which is built through love cannot be strong; but the one which is built by parents' agreement will be strong.

Act 2, Scene 3:16

Mjongwa was most probably killed by the playwright because she wanted to stress her moral lesson.

The marriage ceremony is the climax of the drama, but it is very poorly handled. The appearance of Ntsimbi and his plea about love is not necessary for the ceremony. In any event, people did not even know him. It was known quite a while that Cikizwa would not accept the vows. Why does the author drag this out? It is also surprising that Lola decides to intervene at such a critical stage with such dire consequences.

Ultimately, the suicide of Nonjoli and Cikizwa seem to be motivated: They lose their true loves, Mjongwa and Dike respectively.

In this drama, there is an over-exposure of the aspect of injustices against women just like Mtywaku's uFeziwe okanye inkohlakalo. Mmango concentrates on this issue so much that at times she forgets about characters and events. Her dramatic tension and conflict in this took various forms thus influencing the structure of the play in different ways.

\subsubsection{Inene nasi isibhozo (A. Mtingane, 1965)}

\subsubsection{Episodes}

Inene nasi isibhozo can be divided into various episodes, which have their sub-episodes. 


\section{EPISODE 1: EXPOSITION}

Episode one is the introduction. It is filled with symbolic dramatic actions into which we are plunged. Their symbols evoke in the reader's mind specific images and directive hints to future events. In this skilful manner, Mtingane gives résumé of the conflict that is going to take place in the rest of the play. Mtingane, the playwright, draws the reader into the core issues of cultural perspectives. From the outset, he introduces MaSukude who is the main character in the play. She is a widow. One son, Vuma is hers and the other one, Themba is her husband's from his first marriage. Nosisa, Nolizwe and Somi are the relative's children who also live in MaSukude's household. The circumstances under which MaSukude lives seem to be stressful to her. MaSukude's actions therefore do not operate in a vacuum. She seems to be aggressive; she punishes Nolizwe severely just for the breaking of a cup.

The sub-episode of Episode I offers the problem of Lolo and MaDlamini, Lolo's wife who is the brother of MaSukude's late husband. She enters and attempts to intervene when MaSukude beats the child. MaSukude regards this as interference in her household matters. She becomes angry and reminds MaDlamini about the cruel manner in which they treat her because she is a widow. She cannot tolerate the traditional practice of being dominated. She feels that she is put in a position of marginality. She is locked out of meaningful participation in forging her identity. MaSukude says:

UMaSukude: Ezi zinto zenza umntwana wam isicaka sazo. Ezi zinto zithanda ukulawula.

Ezi zinto zilima ngeenkomo zam. Ezi zinto zivuyelela umhlolokazi

Indima I, Umboniso I:2

MaSukude: These things who treat my child as their servant. These things who like to rule.

These things who plough with my cattle. These things who take a chance with a widow. 
Through MaSukude's well-chosen words like zivuyelela (take a chance), one reads what is in her mind. Her words crystallize her innermost feelings about being dominated in her household.

MaSukude's actions result in conflict that erupts between MaSukude on the one hand and MaDlamini and Mazulu on the other one. The conflict also involves MaSukude's son, Vuma. MaSukude's frustration, stress and anger is portrayed in the pejorative terms (underlined below) she uses when fighting with MaDlamini:

uMaSukude: Suk'apha gagwazanandini!

MaSukude: Go away you brave thing!

uMaDlamini: (Efutheka) uphambene!

Ungumntu na wena MaSukude, esi sikhohlakalindini?

MaDlamini: (Fuming) You are mad.

Do you think you are a human being MaSukude you cruel thing?

UMaSukude: Ningabantu nina ezi zinto?

MaSukude: Do you think you are human beings?

UMaDlamini: Uphi uThemba sikhohlakalindini?

MaDlamini: Where's Themba, you cruel thing?

UMaSukude: UThemba ntoni ntondini?

MaSukude: What about Themba, fool?

UMaDlamini: UThemba wemkiswa yile nkohlakalo yakho.

Gqwirandini elingenanceba ngumntwana ongenanina!

MaDlamini: Themba left because of your cruelty.

You witch who does not empathize with an orphan!

UMaSukude: Uthini nomngcekulanandini?

MaSukude: What do you say, you stupid thing?

Indima I, Umboniso I:2 
The above dialogue together with the well-chosen pejorative terms are a clear indication of a bitter struggle and conflict between MaSukude and the other characters. The tone in which the words are expressed is also meaningful for there is annoyance in it. Habits add background to the static nature of the character. We also gather from the flashback presented by the playwright that MaSukude is responsible for Themba's having left home. Again the flashback informs us that there had been peace and harmony in Njinge and MaSukude's household. Mfolo says:

\begin{abstract}
Kusekho uNjinge, besiyichitha imini sonwabile ekhay'apha, simke kungabangakho kukrwentsana, kodwa ngoku sibetha emva kwezindlu ngenxa yesimilo sakho osiphethe ngezandla.
\end{abstract}

Indima I, Umboniso 1:7

During Njinge's days, we used to spend time in this household happily and then leave without any quarrels, but now we avoid coming here because of your rude behaviour.

Act I, Scene I:7

MaSukude sounds the alarm against Mfolo and other relatives of her husband who invade her privacy ever since her husband passed away. They want to control her home affairs while she wants to be independent. She feels that she is denied a voice, legitimacy and the right to self-representation. MaSukude fights against being confined to the state of an object rather than subject.

Although Themba, Njinge's son has left his home, MaSukude knows that he might come back. It is because of this reason therefore that MaSukude persuades Vuma to get married before Themba returns. Not only that, but MaSukude is also harrassed by Lolo (Vuma's uncle) who makes her household his. MaSukude then instills the idea of responsibility for the household in her son, Vuma.

UMaSukude: Uyaqonda ukuba uyindoda?

Uyiqonda phofu yona into yokuba nguw'umnini walo mzi?

Indima I, Umboniso 4:12 
MaSukude: Do you understand that you are a man?

By the way do you understand that you are the owner of this household?

Act I, Scene 4:12

MaSukude fights physically with MaDlamini on the issue of the child who is beaten by MaSukude. Lolo enters while they are still engaged in this fight. Instead of talking to them as adults, Lolo beats them with a stick. He does not need to beat them. He does this simply because he is a man and this is customary. Lolo's action has a tremendous influence on the development of the story and character of MaSukude.

We learn about MaSukude's character from other characters. MaZulu and MaDlamini have this to say about MaSukude:

MaDlamini: ... Ndiphanjanelwa leliya geza lingumkhuluwakazi wakho.

MaDlamini: ...l am bothered by that mad wife of my husband's elder brother.

UMaZulu: $\quad$... Akukho ntloko apho. Ubusuke wathini wena ...Nithi uMaSukude lo akazi kuphambana?

MaZulu: That one is mad. What did you do?

...Don't you think MaSukude is running mad?

UMaDlamini: $\quad$ Ndiyamazi mna lixesha lakhe lokuphambana eli, inyanga ihlangene nje.

MaDlamini: I know her, she usually becomes mad when there is full moon.

Indima I, Umboniso I:3

Act I, Scene I:3

While the two women are busy gossiping about MaSukude, No-ayini, MaSukude's friend passes by and she overhears them. She does not hesitate to inform MaSukude of the whole conversation about MaSukude. Because MaSukude is always the one who instigates trouble, she confronts them and they start fighting with sticks. MaSukude is severely beaten and she goes home covered with blood. At home, she calls her son, 
Vuma whom she instructs to punish the two women with whom she fought. Though he is a child he agrees to hit them because he is the "man of the family". MaSukude feels that she is not respected. She says to her son, Vuma:

... Ukususel'oko kwabhubh' uyihlo, lo mzi waphelelwa sisidima andisathethi ngesiqu sam, ndaba yinto enyolw'emeh/weni.

Indima I, Umboniso 4:12

... ever since your father passed away, this household has no dignity. I cannot even talk about myself, l'm someone to whom they point fingers.

Act I, Scene 4:12

No-ayini influences MaSukude's character. She encourages Vuma to take revenge for his mother and hit MaZulu and MaDlamini. One notes a cultural issue in what she says:

UNo-ayini: Ufanele unyoko mntwana wam, eligazi nje ulwela lo mzi. Nawe umelwe kukuba bomvu umncedisa kuba lo mzi ngowakho.

Indima I, Umboniso I:6

No-ayini: Your mother is bleeding because she is fighting for this household. You must also be covered with blood assisting her because this is your home.

Act I, Scene I:6

Upon hearing MaSukude's instructions to Vuma, Mfolo and Lolo go to MaSukude to confront her about her actions. Mfolo lays down the law for MaSukude because traditionally, as a man he is the one who can lay down the law. He refers to MaSukude's household as umzi waseMakhwalweni (household of the Khwalo clan). Mfolo's actions have a tremendous effect in the development of the character of MaSukude. Mfolo wants to control everything. He even instructs No-ayini to boil water in order to wash MaSukude's wounds. Mfolo tells Lolo to go with him to check if the water is indeed boiled by No-ayini: 
Mfolo: (kuNo-ayini)

Yiya kufudumeza amanzi sizokuhlamba ezi nduma zikaMaSukude.

Indima I, Umboniso I:7

Mfolo: (To No-ayini)

Go and boil water so that we can wash MaSukude's wounds.

Act I, Scene I:7

Vuma feels guilty by confronting elderly people while being a child. He admits that he did something that is against African custom:

UVuma: $\quad$ Tatomncinci, ndize kucela uxolo apha kuMomncinci ngokusuka ndijamelane naye, ndifune ukumbetha. Ngoku xa ndindedwa isazela siyandixelela ukuba ndenze into engekho sikweni ukufuna ukubetha umzali wam.

Indima I, Umboniso 2:11

Vuma: Uncle, I've come to ask for forgiveness of my aunt for confronting her and wanting to beat her. When I'm on my own my guilty conscience tells me that I have done something, which is against our custom, that is beating my elder.

Act I, Scene 2:11

At first Vuma wanted to fight for his mother, but later on custom overrules his mother. This is a cultural issue that goes against MaSukude.

\section{EPISODE 2: MOTORIC MOMENT}

The second Episode, which is the motoric moment, begins with Themba's problem. Themba returns home. He was away to Cape Town for seven years. This enhances the tension of the conflict. Themba seems to be afraid of going home during the day. He prefers to come at dusk. The soliloquy spoken by Themba seems to explain his emotional state. The words like singa (thorny bushes), ndahlatywa (to be injected) and ubuhlungu (pain) are ominous symbols of Themba's problem. 
Unaware that Themba is on his way home, MaSukude tells Vuma to get married because she does not want Lolo to control her at her household. MaSukude feels that Lolo and MaDlamini, his wife, interfere with matters of her household. MaSukude says:

Mntwanam, ndikhathazwa nguyihlomncinci. Okoko kwabhubh'uyihlo, lo mzi uLolo uwenz'owakhe. Makaphume aphele kulo mzi, uLolo noMaDlamini wakhe abananto yabo ilapha!

Indima I, Umboniso 4:12

My child, I am bothered by your father's younger brother. Ever since your father passed away, Lolo thinks that this household is his, Lolo and his MaDlamini have nothing of theirs here!

Act I, Scene 4:12

Vuma does not agree with his mother. He still remembers his elder brother:

Uvuma: Ekho nje umkhuluwa wam?

Indima I, Umboniso 4:12

Vuma: But my big brother is still alive.

Act I, Scene 4:12

MaSukude wants Vuma to marry urgently. She does not believe that Themba would ever come back. Besides, she wants Vuma to inherit everything so that Themba receives nothing. MaSukude argues:

Ubani? UThemba? Akasayi kuze abuye lowo, wafela kude ekutshipheni. Kodwa makathi ukuba uyabuya, abuye sekudala wazekayo, unezinto zakho, sikhangele ukuba wozikhomba athi zeziphi na ezakhe. Undiva kakuhle kodwa Vuma?

Indima I, Umboniso 4:12

Who? Themba? That one will never come back, he died far away. But by the time he comes back, if he comes back at all, you must have your own things so that we wait and see those which he'll be claiming to be his. Do you hear me Vuma?

Act I, Scene 4:12

There are two related issues here. These are the problems of inheritance and lobola. 
In scene 5 , as children are busy narrating intsomi in their room, Themba enters. One might wonder why he goes to the children's room. From his soliloquy one gathers that he is not aware of his father's death. This therefore is the manner in which the playwright wants to inform him about the death of his father, Njinge, because it is where he is informed by children that his father passed away long ago. Somi informs Themba that:

Utata wabhubha nje

Our father passed away.
Indima I, Umboniso 5:15

Act I, Scene 5:15

Themba's response to the shocking news is:

Ukuba bendazile ukuba akasekho ngendingabuyanga. Lo mzi linxiwa xa engekho

Indima I, Umboniso 5:15

If I had known that my father passed away then I would not have come back.

This house is a deserted home in his absence.

Act I, Scene 5:15

The irony is that Themba is not even interested in this home. He says:

...ngendingabuyanga...

Indima I, Umboniso 5:15

... I should not have come back...

Act I, Scene 5:15

On the following day, Mfeketho arrives at Vuma's place. He sees Themba for the first time after a long time. He seems not to be interested in him at all. He immediately discusses another topic, that is their appointment with girls. Mfeketho says:

Wha Vums, usalikhumbula idinga layizolo?

Indima I, Umboniso 6:16

Hey Vums, do you still remember yesterdays' appointment?

Act I, Scene 6:16

This appointment is the beginning of their meeting with Vuyiswa. At first they are not sure whether Themba should go or not. Later on, they feel that Themba should go also 
because there would be girls or lovers who always accompanied a certain girl, Vuyiswa, who is disturbing them. Themba remains with Vuyiswa. Things are developing quickly. This is a crucial moment.

\section{EPISODE 3: COMPLICATION}

Episode 3 is the complication. It entails Themba's coming back home and the consequences thereof. There is a problem of the ownership of the household after the death of the head of the family and this can be solved by marriage. According to the custom, the older one must marry first. MaSukude wants Vuma to marry:

Ndifuna ke uVuma azeke

I want Vuma to marry
Indima I, Umboniso 7:21

Act I, Scene 7:21

Lolo, the brother of the late MaSukude's husband does not understand why Vuma should marry first. He wonders:

Phofu, kutheni kuza kuqala uVuma, ekho nje uThemba?

Kuqala omdala kakade.

Indima I, Umboniso 7:21

Why will Vuma be the first one to get married and yet Themba is home?

The eldest should be the first.

Act I, Scene 7:21

There is a very serious problem now. Themba is despised by MaSukude. This is one of the crucial scenes because MaSukude makes her intentions known. Lolo and MaSukude do not agree with each other. One identifies a cultural issue because the Khwalo men have to be called to discuss this marriage issue. These men cannot be called by MaSukude because she is a woman. She explains:

MaSukude: Akanakuza xa abizwa ndim

Indima I, Umboniso 7:22

MaSukude: They will not come if they are called by me. 
The reasons for the meeting are Lolo's refusal to solve the marriage problem on his own. Secondly, MaSukude feels that Lolo already favours Themba in this marriage issue. Culturally, Lolo should have solved the problem, but because they once quarreled, then he does not want to commit himself anymore.

In Scene 8, on the other hand, the love issue between Themba and Vuyiswa is sealed. They already call each other Sthandwa (love.)

All the significant actions now derive from the individual motives of the different characters like Lolo, Mfolo, MaSukude, Vuma and Themba. These motives, especially as regards MaSukude and her opponents, are clearly delineated and powerful. These characters have intertwined motives that are a complex mix of customs, strengths and weaknesses. There is an air of challenge and confidence in MaSukude, something not found in traditional wives.

Themba's coming back home leads to conflict as well as the development of MaSukude. Harmony is further disturbed because MaSukude believes that Vuma must marry first because he has been looking after his home. MaSukude says:

Inene nasi isibhozo! Akunakuze kuzekelwe itshiphel'agqiba ishumi leminyaka eKapa ekh'uVuma umntu obelima egcine nezi nkomo.

Indima I, Umboniso 7:21

Truly I swear! We cannot prepare marriage for someone who disappeared to Cape Town for ten years while there is Vuma who was ploughing fields and looking after cattle to consider.

Act I, Scene 7:21

The meeting of the Khwalo clan indicates a particular complication. MaSukude is accused of being responsible for the initial disturbance by the Khwalo clan. From the onset, Mfolo starts laying down the law because he is a man. MaSukude is not expected to discuss household issues with men because she is a woman. Mfolo says:

UMfolo: $\quad$ Ngaba imicimbi yomzi apha siyixoxa kunye nabafazi?

Mfolo: Do we discuss home affairs with women here? 
ULolo: $\quad$ Asiyilungisi nabafazi.

Lolo: We do not solve them with women.

UMfolo: $\quad$ Lo ke umfazi uza kwaneka umcimbi womzi emadodeni uza kusanekela ngabuni?

Mfolo: What about this particular woman who is going to explain home affairs here. What has she to do with them?

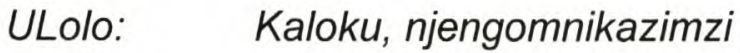

Lolo: On her capacity as the owner of the home.

UMfolo: $\quad$ Wethu, mus'ukundiyilozela. Asinguwe na iliso lalo mzi akubhubha umkhuluwa wakho?

Mfolo: Do not speak nonsense. Are you not this household's overseer after the death of your big brother?

Indima 2, Umboniso 1:24

Act 2, Scene 1:24

This is a microcosm for women's subordination and oppression on a global scale. What transpires from the above dialogue is that MaSukude according to African culture is not expected to discuss her household issues with men. Mfolo has this to say about MaSukude's suggestions:

Bubufazi ke obo ubuthethayo. Thina sithetha ngesiko

Indima 2, Umboniso 1:35

That's women talk that you're speaking. We talk about a custom.

Act 2, Scene 1:35

The Khwalo camp decide to go ahead with Themba's marriage because they think that MaSukude is jealous of Themba. They plan to start with Themba's marriage and then Vuma thereafter. By so doing, they say, MaSukude will realize that they do not have favoritism, they are just following African custom.

The cultural point is stressed by the playwright even in the game played by Nosisa and Somi. What transpires from this game is that boys cannot play with girls. If girls play with 
boys, then boys must always win. Women have their own place. Besides, Nosisa's bravery as a woman who stands up to face the problem during times of trials and tribulations is noted. Somi's cowardice as a man is noted. This is the weakness which will be noticed in Mfolo later. Once more, Mtingane gives us a hint of a symbolic pattern, an indication of what will happen later in the story.

The decision of the Khwalo camp pushes MaSukude too far. She decides to channel her anger in another direction. This leads us to another crucial issue which is the meeting of MaSukude, No-ayini and Mlizo. No-ayini informs Mlizo, her husband, about MaSukude's predicament. She is not satisfied by her husband's response. She goes to the extent of challenging him, saying that just like other men, Mlizo looks down upon women. No-ayini says:

Ngumthetho wenu madoda eli xesha, ukucinga ukuba abafazi aba zizidenge zenu

Indima 2, Umboniso 2:30

That is how you think, man of today, that women are your fools.

Act 2, Scene 2:30

Mlizo tries to pacify his wife by saying:

Tyhini! Bafondini, ndothukile. Ndithube nje ndisamangalisiwe ngulo mhlola uwuthethayo

Indima 2, Umboniso 3:30

Fellows, I'm frightened. I'm keeping quiet because I'm still shocked by what you are saying

Act 2, Scene 3:30

There is a paradox in what is being said by Mlizo. He seems not to be clear about the custom. On the other hand he accepts it.

MaSukude plans to stop Themba's marriage in a dangerous way in order to save the cattle for her son's lobola. She believes that she has a lot of decision-making power, especially in the absence of her husband. MaSukude asks for advice from her friend No-ayini. Noayini suggests that she must remove the stumbling block, that is Themba. MaSukude has 
no interest in permanently removing someone, but she is influenced by No-ayini because clearly, No-ayini is a very strong character. The two women are not wizards as one may suggest. It is a subtle suggestion by the playwright that women are capable of using their brains when need arises and moreover even if they are not in trouble.

Mfolo's speech moves the story action and provides clues to future events. It shows his momentary emotional state. It hints to what is happening in the story. This speech unfolds the plot which is the foundation of the book. Mfolo's speech runs thus:

UMfolo: Ndithi ndikhumbula ndinohambo ngoluny'usuku kusebusuku, kodwa kungemnyama okuthe thsu. Ndandingasibona sisathi thu kanye isilo ngobo busuku. Kuthe gqi kude kufuphi indoda ibambe kany'olu Iwam unyawo ihamba ngale yam indlela. Ndibambe unyawo ndaqondisisa kuba ukudibana nendoda unephika yingozi engamelwe kuphikwa. Ndikhawulezile, naye wangxama, ndee xhungu naye umf'omkhulu wema; ndagoba, nomthakathi wagoba ndaphakama suka waphakama. Ewe ndadinwa ngoku ngulo mdlalo. Ndaphos'imbokothwe esiqwini, ndachol'enye ndayiphos' emntwini ndaphosa enye neny'emva kwenye ...

Indima 2, Umboniso 4:34

Mfolo: I say I remember one night when I had a journey; but it was not very dark. I would even see any approaching animals that night. Suddenly a man appeared next to me, following my footsteps, following my way. I moved quickly because meeting a man while you are afraid is a danger that cannot be denied. I moved fast, and he moved fast as well. I stopped all of a sudden, and the fellow stopped as well. I bent and he also bent. I stood up, and he stood up immediately. O! I became tired now of this drama. I threw a stone at him, I picked up another one and threw it at the person and I threw another after another... 
MaSukude and others. One begins to recognize the bitter struggle and conflict which take place among these characters. This is clearly depicted in the following expressions: "Ndikhawulezile naye wangxama", "ndee xhungu", "naye umf'omkhulu wema", "ndagoba", "nomthakathi wagoba".

Mfolo's aggressive approach does not tame MaSukude at all. Having realized MaSukude's stubbornness, Mfolo decides to lay down the law to MaSukude. He is now tired of MaSukude's bad behaviour of not obeying the people of the Khwalos. This is implied in the following expressions:

Mfolo: Ee! ... ndadinwa ngoku ngulo mdlalo.

Ndaphos'imbokathwe esiqwini, ndachol'enye ndayiphos'emntwini ndaphosa enye neny'emva kwenye.

Indima 2, Umboniso 4:35

Mfolo: Ee! ... I became tired now of this drama.

I threw a big stone at him, I picked up another one and thew it at the person, I threw another one after another.

Act 2, Scene 4:35

The repetition of the word ndaphosa (I threw) and also the use of enye (one) and nenye (another) presents the tensions and conflicts inherent in the story. Mfolo's speech masks the seething rage and frustration of some of the characters like MaSukude, Mfolo, Lolo and others. More importantly this technique warns the reader about the powerful and explosive hostility of the characters.

After the Khwalo clan meeting, MaSukude is called in order to be told about the decisions of the meeting. MaSukude is told in no uncertain terms that Themba must marry first. Her response to that is:

Ndiyaqonda phofu andiqondi

I understand but at the same time I do not understand
Indima 2, Umboniso 4:37

Act 2, Scene 4:37 
MaSukude does not show any arrogance, which surprises the Khwalo clan people. They suspect that she has a hidden agenda because she is known to be brave and she is not afraid of anyone. Mzizi notes:

UMaSukude akoyiki mntu, ndiyamazi kudala ndahlala naye. Engath'uthule nje ngoku akathulanga ufukamile.

Indima 2, Umboniso 4:37

MaSukude is not afraid of anyone: I know her because I stayed with her for a long time. She looks quiet and I know that she is harbouring something.

Act 2, Scene 4:37

Vuyiswa's affair with Themba is developing but Themba is still very secretive about it.

By this time, Themba and Vuma know already that Themba must marry first because he is the eldest. Themba seems not to be happy about the meeting of the Khwalos. He regrets that he agreed to marry first because he does not even like custom's rules. Xhosa custom limits inheritance to the eldest son.

\section{EPISODE 4: CLIMAX}

Episode 4 is the climax. It entails the marriage and other key incidents. It starts with the speech by narrator (umcacisi). It summarizes the whole marriage procedure, starting from the marriage negotiations and the payment of lobola. MaSukude asks for advice from her friend, No-ayini. No-ayini suggests that she must remove the stumbling block, Themba. MaSukude vows:

Kodwa, Inene nasi isibhozo! Uya kuzeka loo Themba wabo ndifile

Indima 2, Umboniso 4:40

But, I swear, that Themba of theirs will marry over my dead body.

Act 2, Scene 4:40

There is an air of challenge and confidence in MaSukude, something not found in traditional wives. She intimidates Nolizwe into serving food with poison. Themba is 
poisoned on the day of his marriage and dies. Upon receipt of the news, Vuyiswa, Themba's wife drowns herself in the river.

When the doctor confirms that Themba has been poisoned, No-ayini and MaSukude panic. Lolo plans to go and inform Mfolo about the doctor's report. MaSukude is afraid of Mfolo because he will know that it is MaSukude who killed Themba, so she wants to prevent Lolo from talking to him. She asks for advice from No-ayini. At first No-ayini says she has no plan but later on MaSukude's insistence, she says that they must poison him as they have done to Themba. MaSukude instructs Nosisa to make tea for Lolo and Vuma. She shows her Lolo's cup and warns her not to make a mistake by changing the cups. She threatens to kill her if she makes a mistake. Nosisa is so nervous that she cannot pour tea properly. Lolo, MaSukude's target, asks Vuma to help Nosisa. Nosisa goes outside crying. Vuma takes the cup of tea with poison. MaSukude enters after they have just finished drinking it. She is surprised when she sees Vuma drinking tea from the wrong cup. Lolo and Vuma are surprised as MaSukude says:

Tyhini Bawo niyigqibile! Ndingathini Nkosi yam ukubulala umntwana wam?

O! Tyhini, No-ayini yityhefu obundinikele ntoni na le?

Indima 3, Umboniso 4:61

O no Father he has finished it! Lord how can I kill my child?

O no, No-ayini, why did you give me this poison?

Act 3, Scene 4:61

By now MaSukude has carried her dreams in a broken vessel. Looking back now she cannot even see a trace of the vanished dreams and expectations she had chosen.

\section{EPISODE 5: DENOUEMENT}

Episode 5 is the denouement. MaSukude's efforts to free women from the bondage of restrictive tradition in marriage, especially concerning widows ends disastrously. She fights desperately to free herself from cultural constraints which are marked by patterns of male dominance. All her efforts are fruitless and this is what is pathetic about the whole thing. She faces the harsh realities of victimization. At the end almost everybody is killed: 
Vuma dies because he drinks Lolo's poisoned tea, Lolo is killed by MaSukude in his attempt to chase her; MaSukude hangs herself.

MaSukude is the cause of these deaths because she has no other access to power, except of treachery and manipulation. Waste of human life is caused unnecessarily because of the patriarchal order that confines women to the domestic arena and reserves for men the arena where authority resides.

\subsubsection{Analysis of the plot structure}

The plot structure of Inene nasi isibhozo can be evaluated according to the following phases:

a) MaSukude fights with most characters in the drama thus showing signs of stress because of domination by Lolo, her late husband's brother.

b) Themba's homecoming and his meeting with Vuyiswa.

c) Men's meeting to discuss MaSukude's problem of who should marry first.

d) Themba's marriage, his murder as well as Vuyiswa's drowning.

e) Deaths of Lolo, Vuma and MaSukude.

f) Funeral of the five characters, Themba, Vuyiswa, Lolo, Vuma and MaSukude.

Some of the events and incidents in this drama are well annotated. They lead to an awareness of the orderliness of pattern in their depiction. MaSukude's stress is well portrayed. She reacts violently to the slightest mistake made by her relatives' children with whom she lives. For instance, Nolizwe breaks the cup by mistake and MaSukude not only swears at her but beats her:

UmaSukude: Uyaphulele ntoni le komityi?

... sidengazanandini! Sondela! (Umbamba ngengalo)

Indima I, Umboniso 1:1

MaSukude: Why did you break this cup?

... you little fool! Come closer! (She holds her by her arm)

Act I, Scene 1:1 
Clearly MaSukude is overreacting because this is an accident that could happen to anyone. In aesthetic terms the breaking of the cup symbolizes the forthcoming problems in MaSukude's household. As MaSukude is busy beating Nolizwe, MaDlamini, Lolo's wife, arrives and tries to intervene. She is taken aback by MaSukude's response:

UMaDlamini: Wenzeni ... ade abethwe kangaka?

MaDlamini: What has she done... to be beaten this way?

UMaSukude: Asiyondawo yakho leyo! Asiyondawo yakho leyo!

MaSukude: That is none of your business! That is none of your business!

UMaDlamini: Ukubuza kunetyala na sisi?

MaDlamini: Is asking a sin?

UMaSukude: Ndithi asiyondawo yakho leyo! Asinguye mntwan'akho lo.

MaSukude: I say that is none of your business. This is not your child.

UMaDlamini: ... Ndone phi na ngo...

MaDlamini: ... Where have I sinned?

UMaSukude: ... Ezi zinto zenza umntwana isicaka sazo!.

Ezi zinto zithanda ukulawula!

MaSukude: ... These creatures who make my child their servant.

These creatures who like to control.

UMaDlamini: Uphambene!

MaDlamini: You are mad!

UMaSukude: Ezi zinto zilima ngeenkomo zam. Ezi zinto zivuyelela umhlolokazi.

MaSukude: These creatures who plough with my cattle. These creatures who take a chance with a widow.

Indima I, Umboniso I:1

Act I, Scene I:1 
It transpires from the dialogue between the two characters that MaSukude holds a grudge against MaDlamini and her husband Lolo. She is not only burdened by having to take care of her relatives' children, but also by Lolo and MaDlamini's interference in her home affairs. She keeps on telling MaDlamini that beating the child is none of her business. The repetition of the sentence "asiyondawo yakho leyo" depicts not only anger but also her desire for them to leave her alone. She emphasizes that by saying "Ndithi" (I say) to assert her point of view, yet MaDlamini does not get the message. They fight immediately after exchanging harsh words. The fight is stopped by Lolo which shows that he is always around MaSukude's home and she detests that. MaSukude is angered also by the fact that her in-laws use her cattle to plough their lands. Unfortunately she channels her anger into a wrong direction by hitting her relatives' children.

MaSukude thinks that the only solution to her problems is for Themba to get married. After the fight between MaDlamini, MaZulu and MaSukude, MaSukude remarks that she is treated badly by the two women because she has no husband. She tells Vuma that ever since her husband died, her household lost dignity. People do as they wish to her:

UMaSukude: NguMaDlamini noMaZulu, bathemb'amadod'abo kaloku. Ukususel' oko kwabhubh'uyihlo, lo mzi waphelelwa sisidima andisathethi ngesiqu sam, ndaba yinto enyolw'emeh/weni.

Indima I, Umboniso 1:6

MaSukuke: It is MaDlamini and MaZulu, they trust their husbands. Ever since your father passed away, this household has been losing its status, it is worse with me; I am something they point fingers at.

Act 1, Scene 1:6

To show that MaSukude is suffering from severe stress she responds angrily at Vuma's question about what happened. This is a very sarcastic statement uttered by a frustrated person:

UMaSukude: Yiya kuyibuza ezintloko kwabaya bantu bayibuz' entloko kum, intsusa yento endingayaziyo 
MaSukude: Go and ask the cause of something I do not know from those people who asked it from my head.

Act I, Scene I:6

MaSukude is not supposed to respond like this to Vuma because he is concerned and really knows nothing about the cause of the problem. As if that is not enough, when Vuma comes back to MaSukude with a dish full of water to wash her wounds, she pours that water on Vuma's face saying that he deserves the whole bucket of water. MaSukude is supported by No-ayini in all her actions. No-ayini explains to Vuma that his mother is fighting for her home and as such Vuma should follow suit because that is his home as well. MaSukude and No-ayini instruct Vuma to beat MaDlamini and MaZulu with his sticks in retaliation.

Later on, Vuma comes back with Mfolo and Lolo and confront her for inciting Vuma against their wives. They even go to the extent of telling her that Lolo is the overseer of her household. Vuma apologizes to MaZulu and MaDlamini because he is embarrassed. He just wanted to please his mother. Otherwise he knows fully well that he cannot do such a thing to elderly people. He must show respect. Vuma is forgiven.

In Act I, Scene 4, MaSukude sees a solution for her problems. She says to Vuma:

UMaSukude:Mntwan'am, ndikhathazwa nguyihlomncinci. Okoko kwathi
kwabhubh"yihlo, lo mzi uLolo uwenz'owakhe. Makaphume
aphele kulo mzi, uLolo noMaDlamini wakhe abananto yabo
ilapha!

Indima I, Umboniso 4:12

MaSukude: My child, I am bothered by your uncle. Ever since your father passed away, Lolo makes this household his own. Lolo and his wife MaDlamini must get out of this household because they have nothing here.

Act I, Scene 4:12

Vuma does not share his mother's views because he thinks that Lolo helps them a lot. MaSukude tells Vuma that he is the owner of the home and as such he must get a wife. 
Vuma reminds his mother about his elder brother who is supposed to get married first according to custom. According to MaSukude, Themba will never come back and moreover by the time he comes back, Vuma must have been given a lot of belongings so that Themba does not inherit a single thing:

UMaSukude:... Kodwa makathi ukuba uyabuya, abuye sekudala wazekayo, unezinto zakho, sikhangele ukuba wozikhomba athi zeziphi na ezakhe

Indima I, Umboniso 4:12

MaSukude: ... But if at all he comes back, you must got married long ago, with your own belongings so that we see which ones he will claim.

Act I, Scene 4:12

Just as MaSukude sees this as a solution for her problems, Themba suddenly arrives. Themba's arrival is not well motivated because there were formally bad blood between him and MaSukude. This is also said by MaDlamini when they were fighting:

UMaDlamini: Uphi uThemba sikhohlakalindini?
MaDlamini: Where is Themba, you cruel thing?
UThemba wemkiswa yile nkohlakalo yakho.
Themba disappeared because of your cruelty

Gqwirhandini elingenanceba ngumntwana ongenanina! You witch who does not empathize with a child without a mother.

Indima I, Umboniso I:2 Act I, Scene 1:2

In his soliloquy in the forest on his comeback, Themba does indicate that he is not on good terms with MaSukude. He even said that he would not have come back had he known about his father's death:

UThemba: Ukuba bendazile ubawo akasekho, ngendingabuyanga.

Lo mzi linxiwa xa engekho

Indima I, Umboniso 5 
Themba: If I had known that my father is dead, I would not have come back.

This household is like a deserted place without him.

Act I, Scene 5

Events move in such a dramatic way that MaSukude is put in more and more serious troubles. The author brings Themba, Mfeketho and Vuma together. Vuma and Mfeketho chat about the appointment they have with girls. Mfeketho does not bother himself much about Themba whom he is seeing for the first time after a long time. He is just interested in their appointment with girls. Vuma and Mfeketho are worried to leave Themba behind, but he does not mind at all. Mfeketho suggests that he must also go because they want him to keep company of the third girl who disturbs them. Themba informs them that he is not interested in girls and he can accompany them if they want.

What is strange is that Vuma and Mfeketho remark that the third girl is beautiful and yet they do not show interest in her. They want to leave her to Themba because they want privacy with their own girls. Themba is left with the girl by the name of Vuyiswa. All of a sudden Themba is head over heels in love with Vuyiswa. It is love at first sight. Even Vuyiswa is surprised:

Ungathini ukuthanda umntu uqala ukumbona? Indima I, Umboniso 6:19 How can you love someone you're meeting for the first time?

Act I, Scene 6:19

Vuyiswa and Themba already call each other lovingly, sana (baby) and sithandwa (love)

MaSukude informs Lolo that she wants Vuma to marry. They clash because according to custom, Themba as the eldest is supposed to marry first. MaSukude is worried about the lobola cattle which will be used in Themba's payment of lobola and that Vuma will be left with nothing.

MaSukude vows that Themba will marry over her dead body. She says that Vuma is the one who was looking after the cattle all these years. MaSukude's in-laws are then called and they decide that Themba should marry first. These men do not even want to hear what MaSukude has to say about Themba's proposed marriage. They believe that as she is a woman, they do not discuss household affairs with her. They also feel that MaSukude 
is jealous of Themba. It is then agreed amongst the men that Themba should be the first one to get married.

Having realized that she is defeated, MaSukude decides to use No-ayini's plan and remove the stumbling block by poisoning Themba. The marriage of Themba and Vuyiswa is contrived and is brought on by the author to put MaSukude into grave difficulty.

The poisoning of Themba is not a good option. By marrying first, he is preventing Vuma from marrying. MaSukude's in-laws are just following the custom. Vuma was going to marry after his elder brother. The author wants MaSukude to be in serious trouble in order to demonstrate the desperate plight of women in an unequal society.

Themba is poisoned and Vuyiswa decides to commit suicide. Vuma dies accidentally because the poisoned food was not meant for him. Lolo also dies accidentally because he was trying to hold MaSukude who later on commits suicide.

A lot of unnecessary deaths occur in this drama: Five people die. The author creates a waste of human life because he wants to emphasize the patriarchal order that puts pressure on women. Just like in the other dramas under study, he does this at the expense of the drama's plot structure.

\subsection{THEME}

Theme is a much-used word in the literary criticism of the drama. Hawthorn (1985:61) observes that a theme may be overt or covert, that is to say it can be either consciously intended and indicated as such by the author, or alternatively discovered in the drama by the reader as an element of which perhaps even the author was unaware.

Furthermore, Hawthorn (1985:61) elaborates:

We can also distinguish between concepts of theme which see it as a central idea and those which view it more as a recurrent argument, claim, doctrine or issue. 
He argues that this distinction linger upon the extent to which a drama is seen not just to contain a particular element, but also to put forward a case for a point of view or established position.

On the other hand, Prince (1982:75) defines theme as:

... a general thought or idea of which a set of sub-propositions (or a set theme) is taken to be an illustration.

It is evident that gleaning from the above definitions of theme by different critics, theme means different things to different people. There are also those who believe that the theme is the message that is embedded in the story.

The treatment of the themes by the authors of this period is so inductively studious, so morally damning and so despairingly pessimistic that the reader easily concludes that these authors are painfully aware of the world of man around them. They are also fully cognisant of what to them seems reprehensible and are deeply disturbed thereby. Their general dissatisfaction at what they perceive as moral and cultural decay in contemporary Africa, has developed into anger and frustration. This disappointment and the anger they feel naturally distil into the mood of their dramas, with the result that some of their dramas overflow with a sense of frustration and despair.

Dramas written during this period reveal that themes that are tackled most are the following:
(a) Buzani kubawo
: $\quad$ forced marriages
(b) UDike noCikizwa
: forced marriages
(c) Inene nasi isibhozo : women abuse

With regard to the first category, that is forced marriages, these plays purport to show that the humanity of women is violated. Their oppressed women characters challenge men who feel that as heads of their families they cannot be challenged. Women are encouraged or forced to be submissive, and humble at all times. In Buzani kubawo, for instance, NomaMpondomise is forced to marry Mcunukelwa against her will and even though she is in love with Gugulethu. 
So is the case in uDike noCikizwa. Sando, Cikizwa's father forces Cikizwa to marry Mjongwa. Cikizwa is told by one of her aunts to be submissive and obey her father's law. Sando goes to the extent of killing Cikizwa's lover, Dike.

\subsection{EVALUATION}

What emerges most vividly from dramas of this period is dramatists who are grappling, as Darby $(1997: 80)$ puts it, with the problem of documenting women's position as victims of their culturally constructed subordinate status while also celebrating women's strength and creativity in resisting that subordination. There is also a question of these dramatists desperately wanting to reclaim the dignity of women and in the process their plot structures show signs of weaknesses and little of strength.

Buzani kubawo's plot, for instance, is simple in order to suit the theme, that is, forced marriages and their consequences. There are many strange developments already discussed, which weaken the drama's plot structure. Some characters like Mzamo are killed unnecessarily.

Mmango who wrote uDike noCikizwa during this period has really demonstrated her concern about the issue of injustices against women. Even in her book some of these problems are exaggerated and in the process the structural elements of the drama, especially plot structure and characters are badly affected. UDike noCikizwa's plot structure is also characterized by flaws. When reviewing a play dramatising social issues, one soon realizes that creating a story is a series of choices. A single social issue could be the focus of any number of different story plots and personalities. In noting the trap authors sometimes fall into, Brooke (1995:1) asks the following rhetorical questions:

So how does an educator distinguish which choices will end in a persuasive story and which are destined to fall flat? What have other educators learned from their experiences with stories they've created or commissioned to motivate audiences to imitate the positive characters portrayed?

In the dramas of this period, detailed information is missing on how and why a specific story was developed, how characters mirror local cultural styles or how audience realities 
are incorporated into the story plot's conflict resolution. Why? Isn't this information the educational core of the stories we use?

Some of the dramas of this period are just vehicles for specific educational messages. May be these authors make their plot and character choices in order to motivate change since they all seem to be resentful of injustices against women. For instance, in the case of Mtingane's Inene nasi isibhozo, some of the incidents and events are well annotated, but the author does spoil his work by forcing his characters to react over some issues thus causing a lot of unnecessary waste of human life. Some of the actions of his characters are exaggerated for dramatic effect. They are larger than life because the author wants to enforce his theme. He does this at the expense of his plot structure.

A focus of MaSukude's development is her tussle to free herself from the bondage of patriarchy and this tussle produces complex lots of problems in which different conflicting voices can be heard. This symbolic first episode of the drama which crystallizes a key moment in MaSukude's life contains dangerous consequences.

One notes adoption of different roles of characters - roles which emphasize the façade of a certain type - a tendency which persists throughout these dramas. Nevertheless, in various respects, then these three dramas under study in this period have an importance that cannot be overlooked. In these works, the spectre of patriarchy looms vividly in the dialectic between women's freedom and autonomy in leisure and the constraints upon them. The dramas of this period give some insight into the meanings and interactions surrounding women's leisure in patriarchal society and in some cases these are exaggerated. My analysis focuses more directly on power at both individual and societal levels. 


\section{CHAPTER 3}

\section{PLOT STRUCTURE IN THE SECOND LITERARY PERIOD (1973-1982)}

\section{$3.1 \quad$ AIM}

An analysis of the plot structures of the three dramas in this period will be attempted, i.e. Ubusuku obungenanyanga, Amaza and uFeziwe okanye inkohlakalo. These plot structures will be evaluated and a summary of the themes in these dramas will also be given.

\subsection{PLOT STRUCTURE}

\subsubsection{Ubusuku obungenanyanga (D.M. Jongilanga, 1973)}

\subsubsection{Episodes}

The playwright introduces the theme of gender equality whose institutions in which it is embedded have a long and complex history. Through his characters the artist Jongilanga, describes the male dominated world we live in where women are primarily expected to concentrate on child-rearing and home maintenance.

The following episodes can be distinguished in the plot of Ubusuku obungenanyanga. The play is not divided into acts and scenes. It is divided into chapters.

\section{EPISODE 1: EXPOSITION}

Episode one is the expositional episode, the introduction. In this episode, the playwright introduces characters who will instigate the whole conflict on which theme and intrigue is based. In Scene I we get to know Novayithi, Solani's wife and the fact that as a woman she is expected to be solely responsible for household chores. Novayithi is expected to conform to all the rules that characterized the relations of wives to patrilineal elders, particularly male elders. We become aware that there is no food nor paraffin at Solani's home and Solani does not bother himself about this predicament. He is moving up and down in the location in search of shebeens. It is Novayithi who moves from pillar to post begging for food from gossiping neighbours. At times Novayithi is so embarrassed that on 
certain instances she sends her children who are often agiven tough time by her neighbours. At one stage, MamCirha says to Ziphilele, Novayithi's son:

\section{MamCirha: Uthin'unyoko? Uthi nantsi intoni namhlanje? \\ Uzumxelele unyoko ukuba ipalafini kum yinto esemagqabini, nalaa ntwana ndinayo, ndincedwe nguNomakhephu lo, aze akhe azame madlelo wambi, kuba eli lindim liphanzile, uyeva?}

Isiqendu I:2

MamCirha: What does your mother say? What is it that she says today? Tell your mother that paraffin to me is a luxury even the little bit I have was given to me by Nomakhephu. She must rather try some other places, better places, because this can of mine is dry, do you understand?

Chapter I:2

MamCirha says all these humiliating words in front of her friend, Nomakhephu. Ziphilele leaves them and the two women discuss Novayithi's children who are always dirty. They criticize Novayithi also who keeps on giving birth to children of an irresponsible drunkard knowing fully well that she is struggling to support them. The dominant role of the husband and the subordinate role of the wife are clearly delineated in Novayithi's behaviour. She finds herself in a position where she is trained to be obedient, cooperative, submissive and patient. Novayithi comes to believe and incorporate the gender roles defined by society into their self-concept, and begins to experience and live her life by these roles and expectations, which in turn come to feel like a natural part of her personality.

MamCirha and Nomakhephu blame Novayithi for not forcing the man to go and work.

While the two women are still chatting about Novayithi's actions, Nomakhephu receives an urgent call to get home as soon as possible. Mamfene confronts Nomakhephu about the money which she was supposed to give to her. That money was in a letter and it was given to her by Madoda, according to Mamfene. To show the superiority status of men in society, Nomakhephu has this to say about the way homes without men are treated: 
Ukuba uhleli ndla, makube ushiywa ziingqondo. Ujonge wajonga kule lali, wabona ukuba mawuze kulo mzi ungenandoda?

Isiqendu 1:6

If you're wide-awake I am sure you are out of your mind. You look and look all over the place in this rural area and decided to come to this home without a man?

Chapter 1:6

In Scene 2 (referred to by the author as Isiqendu) Mamfene arrives at the headman's place to lay a charge against Nomakhephu who is accused of taking MaMfene's money from Madoda. The headman and Dalasile demand that Mamfene should tell them what she would like them to do for her. Mamfene responds by saying that she wants them to demand her money from Nomakhephu. The case is postponed because they want to summon the other parties as well.

\section{EPISODE 2: MOTORIC MOMENT}

Episode 2, which is the motoric moment, concerns the discussion of the issue of Mamfene's money at the headman's place. Nomakhephu, the accused is present also. She denies that Madoda ever gave her money. She feels that she is being accused because she is widowed. She says:

Yinto yokuba bethu ndingenamthetheleli kuba kweyam indoda kwangcol'ungele? Is it because I have no protector because my husband passed away?

Isiqendu 3:11

Chapter 3:11

Madoda is summoned also, to identify the woman to whom he gave money. He says that the women are not in the meeting. Madoda informs the headman and his men that he met the woman to whom he gave money only that morning. It is then decided in the meeting that Novayithi and her husband, Solani, should be called. Nomakhephu reacts angrily. In response to Nomakhephu's anger, Njomane remarks that women are not needed in court because of the manner in which they behave. 
Njomane: Nagxothwa enkundleni ngezi zinto, asizi kuphekuzana nawe ngathi salusa iintakazana emzimbeni

Isiqendu 3:13

Njomane: You were driven away in court because of these things, we are not prepared to silence you as if we are looking after birds...

Chapter 3:13

Novayithi and Solani arrive. Madoda assures the court that he gave money to Novayithi. Novayithi denies this. She says that the only thing that was given to her by Madoda was a letter. Apparently she was not aware that there was money in the letter and she lost the letter. Novayithi explains that she has not yet reported the loss of the letter to its owner because she is still looking for it. Moreover, she is afraid of Mamfene's response upon receipt of the news about her letter. Novayithi denies that she introduced herself as Nomakhephu to Madoda. The headman then decides that she must pay the money.

While the tribal court is finalizing Novayithi's case, boys storm in and call their fathers. Nkosana, Nomakhephu's son is unconscious. Nomakhephu, shocked, shouts at them. She demands an explanation as to what the cause of the problem is. The headman instructs Mzamane to follow the boys. He tells the women to stay behind.

Sibonda: ... Mzamane, khawulezani nilandele la makhwenkwe, siza kulandela. Abafazi mabasale ngasemva.

Isiqendu 4:15

Headman: ... Mzamane, hurry up and follow these boys, we'll follow. Women must stay behind.

Chapter 4:15

Dengana, Novayithi's and Solani's son, kills Nkosana. Solani does not know what to say to Nomakhephu. He is short of words. Dalasile responds to Solani's problem and shock by saying:

Mfondini ungazenzi umfazi - yeka sesisondela kwaba bantu Isiqendu 4:17 Fellow, do not behave like a woman - keep quiet. We are getting closer to these people. 
The above dialogue between these male characters portrays the way they marginalize women. They look down upon them.

The headman and his group break the news to Nomakhephu who cries uncontrollably. Police are called to interrogate Dengana, the murderer. It can be seen from the way Dengana answers the questions that he is not normal. His father Solani is aware of this. Dengana is taken to the psychiatric hospital for observation before being charged of murder.

\section{EPISODE 3, COMPLICATION}

Episode 3, which is the complication, fulfils the earlier suggestion that one of the concerns which Jongilanga conveys in the play is the powerlessness of women and the fact that women are alluded to as being inferior. Women are expected to stay at home, maintain the homes and concentrate on child rearing. Solani blames Novayithi for Dengana's murder case. He says:

Solani: Sukugeza man! Yonke le nto kukungakwazi kwakho ukuqeqesha, uhlala naba bantwana mihla le kweli khaya

Isiqendu 5:20

Solani: Do not be silly man! It's all because of you. You have no discipline. You stay with these children everyday in this home.

Chapter 5:20

The violent confrontation between the two characters, Novayithi and her husband Solani, ensues. Novayithi is angry. She tells her husband that it would be better if he was at work. If that was the case, then Novayithi would gladly raise their children. The sad part is that Solani is busy enjoying himself at the shebeens while Novayithi is desperately trying to keep the fire burning at home. Solani confronts Novayithi about Mamfene's money. He suspects that his wife misused that money. Novayithi defies her husband and he beats her with a stick. Fortunately for Novayithi, Njomane enters their home and stops the abuse. Novayithi tells Njomane that Solani is used to beating her and yet he does not do that to the other men. Once more Solani shows that he wants to show Novayithi her place because she is a woman: 
Solani: ... Khawuyeke man ndikhe ndimbeke kwindawo yakhe.

Isiqendu 5:21

Solani: $\quad$... Leave me alone man so that I can put her in her place.

Chapter 5:21

Showing women where "their place" is, is one method of denying them power. Solani treats his wife as a child or "an incompetent" adult. A reduction of women to the status of children is apparent in Solani's dialogue. Novayithi is reprimanded like a child. Her husband chases her because she challenges his authority in the house.

The subtext of the power struggle between the sexes in Jongilanga's play is that Solani has lost total control of power. Hence, he must try to exert control by physically abusing his wife.. Even the way Solani refers to his wife demoristrates vividly that he does not respect her. He explains the cause of the fight to Njomane:

Solani: $\quad$... Bendisaphanda le mali kulo mfazi

Isiqendu 5:22

Solani: $\quad$... I was still enquiring about this money from this woman.

Chapter 5:22

The word kulo is used in a very derogatory manner. It shows disrespect as well.

\section{EPISODE 4: CLIMAX}

Episode 4 is the climax of the play. Novayithi has disappeared. Solani is worried about her whereabouts because she did not even attend the funeral of Nkosana. She went to fetch water from the river and she did not come back. Her children found the bucket in the river. Solani wonders if Novayithi decided to leave him because she was thrashed. He feels that if that is the case then it means he is not married yet because an African woman is trained to accept abuse in marriage. Solani says:

Simanga somfazi esi. Ngaba uyephi bethu? Ukuba ubalekiswe kuba ndikhe ndamtshiza, inene ukuba kunjalo, andikabi namfazi tu tu

Isiqendu: 6:25 
This is a strange wife. Where could she have gone? If she decided to run away because I thrashed her then it means I do not have a wife yet at all.

Chapter 6:25

Apparently Solani is used to severely physically abusing Novayithi, but she has never so far decided to leave him. When speaking about his wife he refers to her as "this woman". He does not use romantic terms that show love and respect at all. He sees her as an object. Solani has this to say to Njomane:

... Lo mfazi ndiqhele ukumbetha alale ngendlu, akazange ayenze le ayenze namhlanje

I am used at severely beating this woman and she has never decided to do what she has done today.

Isiqendu 6:27

Chapter 6:27

Novayithi is pushed too far now. Solani, the product of a patriarchal society still does not believe that Novayithi cannot tolerate this treatment anymore simply because she is an African woman. Xhosa women, it is believed have a great capacity for endurance and patience. Zamani tells Solani that Novayithi has had enough. Apparently Novayithi decided to go to her parents' home. The disappearance of Novayithi is the talk of the place.

At her home, Novayithi meets Zingiwe and they discuss their problems. Zingiwe tells Novayithi that she is liberated because she is no longer married. No man bothers her anymore. She asks Novayithi if she is still patient with her husband's abuse. Novayithi feels that she cannot leave her husband because she has many children. Zingiwe does not understand her because one can leave an abusive husband even if one has many children. Novayithi is determined that she cannot leave her household. She comes home just for a break from her husband's abuse.

Novayithi arrives home. Nolusapho, her mother accuses Novayithi of being head over heels in love with the abusive man. She does not accept that at all. She questions the fact that she has many children by an abusive man. 
Solani and his friends decide to visit Novayithi's home thus looking for her. Apparently Solani has not even finished paying lobola for his wife. Solani and his group are punished. Before any discussion on Novayithi's issue they have to pay their in-laws. They are told to go back home without Novayithi. That is one of the important customs in Africa culture, which teaches men to respect their wives. The payment is sometimes in the form of cattle, money or liquor.

Novayithi stays at her parents' home for three months. During this period she works in one of the shops. One of her children comes to see her oneday.

Novayithi is worried because she learns from her daughter that most of the time they live on their own without their father. Her mother is furious when she realizes that her daughter, Novayithi, wants to go back to her household. Nozenza, her mother's friend accuses Novayithi of being satisfied with the physical abuse just like other young women who see it as a sign of love. Novayithi tells her mother that she is leaving with her daughter. She tells her mother that her home is in her household. Novayithi says:

Mama, andinakhaya lilapha nawe uyayazi loo nto ...

Mother, my home is not here and you know that very well
Isiqendu 11:44

Chapter 11:44

MamGqwashu, Novayithi's mother reacts angrily, saying that she will never speak again because she never knew that a stick can build a home. Ultimately Novayithi goes back to her household despite her mother's subtle pleas.

On her arrival home, Mamfene, demanding her money, confronts Novayithi. Novayithi is defiant, but ultimately she decides to pay the money. Apparently she got money from her parents.

After four months there is neither food nor money at Novayithi and Solani's home. Novayithi suggests that they should discuss this sad state of affairs. Solani does not want to, instead he demands coffee. He tells Novayithi that he is not the first man to be unemployed in their place. Solani remarks that Novayithi does not know how to behave in married life. 
Solani: $\quad$ Uyaqala ukubona indoda engaphangeliyo kule lali ngam

Lo? Awukwazi ukwenda Novayithi.

Isiqendu 15:55

Solani: Is it the first time for you to see a jobless man? You do not know how to be married Novayithi?

Chapter 15:55

It transpires from Solani's dialogue that a woman must be very tolerant and understanding if a man is jobless. If a woman does not understand, then it means that she is not fit to get married. Solani tells his wife that other married women whose husbands are jobless know very well that they are the ones who must keep the fires burning at their homes. The two characters argue angrily. Solani threatens to beat his wife. He says:

Novayithi undilibele hi? Thul'uthi tu. Ndithi thul'ufe ukuba akufuni ngozi Cwaka

Isiqendu 11:50

Novayithi you have forgotten me, eh? Keep quiet. I say keep quiet if you do not want to be in danger.

Silence

Chapter 11:50

Novayithi is in serious trouble. She owes many people in this village money. Nohantom arrives at Novayithi's place to demand her food. As she is busy trying to persuade Nohantom to understand her circumstances, Zanele arrives at Novayithi's place to remind Novayithi about her mother's food, which she has not yet returned. Whilst Novayithi responds to Zanele, Nohantom angrily says that she is not prepared to leave Novayithi's place unless she pays her. Novayithi is in a very humiliating situation because Zanele further tells her that her mother does not expect to go back home without her food. Novayithi defiantly tells Zanele to leave her alone because she will bring her dish of food later on. Nohantom continues bothering Novayithi about dishes of food she owes her. Solani is not in trouble because he is always in shebeens when his wife moves from one home to another begging for food for his family.

Solani tells his wife that there are still some other homes which she does not owe food and as such she must go and beg for food in those homes. It is at this stage that Novayithi suggests to her husband to change man and women roles. She tells him to wear her 
dresses and move from one house to another begging for food so that he can experience the humiliation himself. She says:

Khawuthathe iilokhwe ezi zam, sitshintshe izikhundla, khe sikhangele ukuba wobuya undixelela ntoni na wakuya kule mizi

Isiqendu 1:25

Take my dresses, so that we can change roles and hear what you will be saying on your return from these homes.

Chapter 1:25

Solani accuses Novayithi of not being interested in listening to his advice while according to him, she is the one who is in trouble.

Solani's family is starving and the only person who is expected to make ends meet is Novayithi. Novayithi decides to go to MaDlamini's home. The two women at MaDlamini's home see her coming at a distance. They already know what her problem is and blame her for not forcing her husband to go and look for a job. Moreover, they say, Novayithi always gives her husband food whenever he goes to drink liquor in the shebeens. Novayithi arrives at MaDlamini's home. They give her a piece of their mind about her actions towards Solani. Nokhaya tells Novayithi not to give Solani food. She empathizes with her and gives her food saying that she is doing it for the last time. The women at MaDlamini's home tell Novayithi to do something about her predicament. She promises to heed their advice.

Solani and family are having their supper late because they were waiting for Novayithi to come back from begging in the village. Solani tells his wife that he thinks about leaving their home very soon. Novayithi does not believe him anymore. She reminds him that she is the one whose dignity is lowered because she is always begging or food for her family. Having said that, Novayithi breaks down and cries painfully. She utters the following sad words:

Uyazi ukuba andisahambi ndawo, ndaba yihagu yeli khaya, iqaqa lale mizi iphela. Abantwana bam ndibaphethe ngamazinyo ukho ungayanga kukha 
mbotyi. Ndide ndalisela kuba ndifuna ukufundisa abantwana bam. Imnandi kuwe loo nto? Hi? Kuhlekiswa ngam.

Are you aware that I am no longer going places, I am a pig of this home, a poll cat at all these homes, I am raising my children alone under very difficult circumstances even though you are here. I am a thief now, because I want to educate my children. Is that nice to you? I am a joke.

Solani leaves very early on the following day with one of his children. He comes back with four donkeys. Novayithi is shocked when she sees the donkeys. She asks him why he did not buy cattle like other men. Solani plans to plant mealies and beans with the donkeys. He requests mealies and beans seed at the shop because he does not want to bother the people of his village who are already bothered by Novayithi. Solani decides to leave his family to seek for a job in East London. He promises Novayithi that he will send her potatoes to be ploughed in the garden.

Solani arrives in East London. He puts up at his homeboy Mazinyo Kosani who left his home long ago. Solani asks Mazinyo to assist him in looking for a job. He explains all his miseries to him. Solani stays for two weeks without getting a job. Later on Solani is employed by MamTola. Solani does not like MamTola's job. He feels that it's a job for boys. Maso warns Solani not to sabotage his own jobs. He reminds him to reward him for his help later on.

Solani gets a job at Toni's place. He gets accommodation at Bike Street, Tsolo. He buys himself a few things like a bed and a stove. Solani gets his first payment and buys liquor for his friends as a token of appreciation for what they did for him. Lemmy reminds their women friends that their place is in the kitchen.

Later on Nomatshayina and Nomasoka join Solani and Lemmy in drinking liquor. As they enjoy themselves, Solani complains that he has no one to wash his clothes. He is used to being assisted by his wife because he is a man. They are joined by Lydia. Having enjoyed themselves, they decide to go and relax at their places. Solani goes to his place with two girls, Nomatshayina and Nomasoka. They put up at Mtyeku and decide to drink 
liquor again. Solani becomes extremely drunk. The two girls take all his money even from his pants. On the following day Solani is shocked to find that he is penniless. He confronts Nomasoka and Nomatshayina. All this time, Solani has completely forgotten his family. Novayithi asks Zingiwe who recently went to East London whether she saw her husband. Nursing her feelings, Zingiwe does not want to tell her the truth. Novayithi does not experience many problems now. Some of her problems are solved by their farmer who sold her harvest in order for her to get money. Ultimately, Zingiwe tells Novayithi that her husband is in love with another woman. Novayithi's self-esteem is now affected by Solani's actions. She looks down upon herself. She says:

Ke kaloku Bhelekazi uthi into exwebe njengam nje, enobuso obuneentanda, enuka udaka nomsi ingamelama njani nezicukujeje ezinuk'umlungu?

Isiqendu 22:82

Bhelekazi, do you think someone like me with dry lips and a face with wrinkles, someone who smells of mud and smoke can compete with smart people whose smell is like that of the white people?

Chapter 22:82

Zingiwe reprimands Novayithi for allowing Solani to oppress her for so many years. She warns her that it is too late for her to redress her husband's oppressive actions. Zingiwe says:

... wakugqiba ukuyigezisa indoda usengumtshakazi ucinga ukuba ungabuye uyaphule iimpondo emva kwemini?

Isiqendu 22:82

Having allowed your husband to oppress you ever since you got married, do you think that you can change him this late?

Chapter 22:82

Zingiwe further warns Novayithi that Solani might come back home with another woman. Novayithi displays reaction when she says that it will never happen at all. She is desperately trying to reclaim her humanity. 


\section{EPISODE 5: DENOUEMENT}

Episode 5 is the denouement. It reflects Solani's downfall as well as Novayithi's resistance to patriarchal oppression. In East London, Solani does not want to go back to work on a certain Monday following their joyful weekend. He is suffering from a hangover. His girlfriend Nomasoka persuades him to go to work. He refuses, citing the fact that his woman boss will reprimand him for reporting late for duty. Solani says this clearly undermining his woman boss. Solani's dialogue is always characterized by arrogant phrases like laa mfazi (that woman) when talking about women. He says:

Uza kundigezela laa mfazi ngokuphosa ixesha lokungena Isiqendu 21:80

That woman will give me tough time if I do not report early for duty Chapter 21:80

MamTola, Solani's boss reprimands him for coming late. Solani is not apologetic at all. $\mathrm{He}$ becomes aggressive and tells MamTola that she behaves in this manner towards him because she is rich. Solani says that he cannot be treated badly by a woman because he is a man. He says:

Ukuba uqhele ukuphath'indoda yakho, andiyiyo mna, andinakuphathwa ngumfazi olu hlobo.

Isiqendu 23:85

If you are used at bullying your husband, I am not your husband and I cannot be bullied by a woman.

Chapter 23:85

Solani demands his salary from MamTola and he is then fired immediately thereafter. Makhaya, MamTola's messenger comes in order to protect MamTola from Solani.

Solani is now jobless. He informs Nomasoka about his problems. Like the prodigal son, Solani thinks about his home. Apparently he has been informed by Zingiwe that his family gains a lot of profit from the harvest of their beans and mealies. The only difference between him and the prodigal son of the Bible is that he does not go back home to ask for forgiveness. He goes back home with another woman, Nomasoka, thus creating more serious problems for himself and Novayithi, his wife. Nomasoka advises Solani to go 
home and take all his money from his wife so that they can buy a house in East London and enrich himself. Nomasoka does not want to be left behind because she does not trust Solani who can easily change his mind upon arrival at home. This reminds one of the Xhosa saying about men that:

Amadoda alala neli avuke neli

Isiqendu 23:80

Men say this today and on the following day they say something else

Chapter 23:80

At first, Solani is reluctant to accept Nomasoka's advice that he should go home with her. He threatens her about his wife. He says:

Uyamazi umkam?

Isiqendu 23:86

Do you know my wife?

Chapter 23:86

On the following day, Solani goes home with his concubine, Nomasoka. They arrive home at sunset and everybody is present there. One of his children, Nontwazana, is excited when she sees her father. Njomane, a family friend is also at their home. Novayithi requests Nontwazana to make tea for Solani and Nomasoka. Novayithi wants to know who Solani's girlfriend is. She wants to know if it is the other woman who lives with Solani in East London. Nomasoka boldly responds by saying that lobola is paid for her just like Novayithi thus implying that she is also married to Solani. Novayithi is taken aback. She tells Nomasoka that this is her home and as such they must leave her alone in her place and get their own home:

Kukwam'apha. Ukuba wendele kulo Solly hamba naye ngoku nizifunele elenu ixhobongwana. Nditsho.

Isiqendu 24:88

This is my home, If you are married to this Solly, then go away with him now and get your own home. I say so.

Chapter 24:88

Novayithi stands up and tells Nontwazana to hurry up in making tea for the guests so that they can leave because she has no place for them. 
Solani believes that Novayithi is overreacting. He asks Novayithi if there is a man who has already taken his place. Novayithi burns Nomasoka with boiling water unexpectedly. Nomasoka is in terrible pain because of the severe burn. She groans:

Yho! Yho! Undigqibile

Isiqendu 24:90

Yho! Yho! She has finished me
Chapter 24:90

Novayithi, holding a pot with boiling water, turns to Solani, who wants to retaliate. Solani runs away and Novayithi chases him. Njomane helps them to escape the wrath of Novayithi who now sees red. They run to the headman's place. Novayithi drives them away saying that she will get them.

\subsubsection{Analysis of plot structure}

The drama can be divided into the following phases:

a) Novayithi's burden of being the only parent in her household who is solely responsible for household chores. Her husband Solani is enjoying himself in the location. Novayithi moves from one home to another, begging for food from gossiping neighbours. At times she sends her children and she is subjected to ridicule for having many children. Women blame Novayithi for not forcing her husband to go to work.

b) Novayithi is in trouble. Madoda gives her Mamfene's letter with money inside. Novayithi loses the letter and she is not even aware that there was money in the letter. The case is discussed at the headman's place. Novayithi and Solani experience another problem. Their son, Dengana, kills NomaKhepu's son, Nkosana. Dengana apparently is not a normal child and he is therefore taken to the psychiatric hospital for observation before being charged with murder.

c) Novayithi is suffering more and more. Solani blames Novayithi for Dengana's murder case. Confrontation between Novayithi and Solani takes place. Solani starts accusing Novayithi of stealing Nomakhephu's money and Novayithi defies him. Solani beats Novayithi. 
d) Novayithi disappears and Solani becomes worried. Solani does not understand Novayithi's decision of leaving him because he thrashed her. As a woman, she is supposed to accept his treatment.

e) At home Novayithi is criticized by her mother for having a lot of children by an abusive man. Solani and his friends go to Novayithi's home. It emerges that he did not even finish paying lobola. Nothing can be discussed with them without first finishing the payment of lobola. They go home without Novayithi. Novayithi decides to go back to her umzi because she is not only worried about her suffering children. She feels also that her home is in her umzi.

f) At Novayithi's household things are still the same. Solani has not reformed at all. Novayithi owes people a lot of money and they confront her. She is humiliated. Solani continues to abuse Novayithi because he forces her to go and beg for food to other homes. Later on Solani buys donkeys after having left home looking of a job. They plough mealies and he decides to look for a job in East London. He works and gets money. Having met women friends he decides to spend his money with them.

g) Solani comes back home with another woman by the name of Nomasoka. Novayithi reacts aggressively. Having been boldly told by Nomasoka that lobola is paid for her, Novayithi forces them to leave her alone. Novayithi burns Nomasoka with boiling water. She prepares to burn Solani as well. Their friend, Njomane, who was present during all this time, helps them to escape the wrath of Novayithi. They run to the headman's home.

The plot structure is not well divided: It is not divided into acts and scenes, but according to chapters.

The author's plot progression, however, is well orchestrated. His events do unfold in a skilful manner. Jongilanga's plot is launched by a conflict and then driven toward a final resolution. Between his first episode and the end of the play there are a number of complications and confrontations which occur to build excitement and suspense.

Novayithi's suffering under the oppressive treatment of her husband, Solani, unfolds artistically. She quarrels with her husband who does not want to work for his family and in 
the process that burden falls on Novayithi's shoulders. In trying to make ends meet, she clashes with her gossiping neighbours. She is extremely humiliated.

Things complicate when she is accused of stealing money and at the same time her son kills the very son of the character whose money she "stole". Jongilanga's theme of injustices against women does spoil his character portrayal. Novayithi is suffering a lot. Even the other women characters question her kid-glove treatment she does to her husband. She is a little bit larger than life and slightly exaggerated for dramatic effect. He forgets that characters must still be recognizable and familiar to the audience. Characters as Brooke (1995:65) puts it must be interesting enough to generate strong emotional reactions. The audience needs to understand and care about the characters they disagree with for the play to have balance.

The author even goes to the extent of killing the son of the character whom Novayithi owes money just to make Novayithi suffer, because in the process, it is Novayithi who is blamed by Solani for this cruel deed.

Novayithi leaves her household after having been physically abused by Solani and Solani is punished by her family. Solani and the men who accompany him do not go back to Novayithi's home to pay lobola. After a few months, Novayithi decides to go back to her household against her mother's will. One wonders where her African pride as a woman is. This is caused by this overexposure of the author's theme: injustices against women.

Novayithi is maltreated till the end of the drama because even though their lives change financially, Solani continues to abuse her. He gets a job in East London and he starts having love affairs with other women. Solani even goes to the extent of deciding to go home with one of his girlfriends. It is then that he sees the wrath of his wife Novayithi.

Clearly Novayithi represents injustices against women. On the other hand, Solani represents male dominance. While, almost every significant action in this story derives from the individual motives of different characters and these motives are clearly delineated and powerful, but they are exaggerated.

What emerges vividly from this drama is that the author feels that women are victims of an unjustified form of gender marginalization. Novayithi in this play struggles in various ways 
to create a space for herself within the controlling patriarchal ideology. The author portrays women as being involved in conflicts and contradictions. Novayithi, for instance, severely criticizes her husband's actions in direct confrontations. Of course she does this at a very late stage, having allowed her husband to oppress her. Novayithi's actions are more a means of survival for her.

\subsubsection{Amaza (Z.S. Qangule, 1974)}

\subsubsection{Episodes}

\section{EPISODE ONE: EXPOSITION}

In episode one, which serves as an introduction, the play opens with Namhla who is left alone at home by her parents Danile and MaDlamini. Namhla is an adopted child. She is in a very aggressive mood because she is about to be forced to get married against her will. To show her dissatisfaction she utters the following words:

(Ebek'unyawo phezu kwebhokisi)

Tyesi itheni yona le ngathi yeyamajoyini

(Uya ngasefestileni afike eme)

Hayi ilishwa lomnt'ozalwa ngamaqaba!! Usikelelwe umntu ongaphathwange njengenkedama.

(Uya ebhokisini akhuphe ilokhwe yejelimani ayidweze)

Yena lo vunkxu usisizothezothe!

(Uyigibisela etyesini ayinyhale ngonyawo)

Ngahle uphele lo mtshatwana iluthuthu. Esona sambatho sobukhoboka sesi!

(Uyayifaka ebhokisini egibiselekile)

Ngathi ndiyazibona ndambathe obu bubhanxa!

Uyayichul'uMgozi xa usithi

Sisibetho ukutshata ixathawana ngokunyanze/wa!

Indimo I, Umboniso 1:1

(Putting the foot on the kist)

What type of kist is this?

(She goes to the window)

How unfortunate it is to be born to traditionalists! The one who is not treated like an orphan is blessed! 
(She goes to the kist and takes out a traditional dress and pulls it apart)

This ugly dress is disgusting!

(She throws it in the kist and tramples it)

By the end of that marriage, may it be burnt to ashes. This is an attire for slaves!

(She throws it quickly in the kist)

I do not picture myself wearing this stupid thing. Gossipers are quite right when they say that marrying a foolish person by force is a curse.

Act I, Scene 1:1

That Namhla is a protagonist, there is no doubt. She fights for her rights. The above passage indicates her displeasure of being forced to marry someone she does not love. Namhla associates the traditional attire bought for her by Danile and MaDlamini with slavery. Her actions of trampling on this attire demonstrates that she is totally against the forced marriage tradition. The adjectives which she uses in describing this attire depict her anger. From this passage, readers deduce that Namhla is not going to allow her parents to do as they wish. Namhla will oppose them whether they like it or not.

Namhla's action of going to the window after having complained about the cruelty of being treated like an orphan symbolize that she is longing for freedom. Namhla has an objective - to marry a man of her own choice. It is this objective that readers will follow during the course of the play.

Lizo Vaxa, Namhla's boyfriend arrives and apparently Namhla has long been waiting for Lizo. It is clear that Namhla and Lizo's objective is to be married. They utter the following words:

Lizo: $\quad$ Sitshayelela umtshato wethu ke ngoku.

Namhla: Ibuhlungu le nto uyithethayo

Lizo: $\quad$ Sitshayelele sagqiba, ngoku siza kutshata

Namhla: Uphi umfundisi?

Lizo: $\quad$ Umfundisi luthando Iwethu

Lizo: We are preparing for our marriage.

Namhla: What you are saying is very sad. 
Lizo: We have completed the preparations, and are now going to get married.

Namhla: Where is the pastor?

Lizo: $\quad$ Love is our pastor.

Act I, Scene I:5

Namhla and Lizo are determined to achieve the ingredients of marital relations, such as love, mutual respect, peace and harmony. They discuss their respective partners forced upon them by traditionalists: Sidima for Namhla and Zodwa for Lizo. Apparently Sidima was going to court Zodwa. Lizo and Namhla complain about Sidima and Zodwa who are obstacles that obstruct their plans for marriage. Their parents also impose cultural constraints on them. Lizo and Namhla are champions of European values that are in opposition to African values. Traditional African values believe that marriage should be arranged by the community. However, Lizo and Namhla consider African practice a stumbling block to the attainment of their objective. Lizo remarks:

Bendingazi ukuba singathintelwa zizidengwe zamaqaba kwiinjongo zethu Indima I: Umboniso 1:5

I did not know that we could be kept from our objectives by ignorant fools.

Act I, Scene I:5

Lizo and Namhla's Actions and dialogues suggest clearly that the practice of parent's choosing one's marriage partner is not acceptable. Sirayi (1993:75) suggests that this cultural practice propals the story very far dramatically, as there is active opposition to Lizo and Namhla's marriage. As Namhla and Lizo are busy discussing their problem, Danile, Namhla's father arrives. He forces Lizo to leave his home, calling him a dog.

Meetings are held frequently by the community to thwart Namhla and Lizo's objective. Having chased Lizo away from Namhla, Danile has this to say about Lizo in one of the meetings:

Ndithi mandinazise maBhele ukuba ndifike ingqeqe kaVaxa ijoja uNamhla xa bendivela kuzonwabela etywaleni 
I felt I should summon you, men of the Bhele clan. I found Vaxa's dog smelling Namhla on my return from drinking beer.

Act I, Scene I:7

Finally, Namhla and Sidima are forced to get married as well as Lizo and Zodwa on the other side.

\section{EPISODE TWO: MOTORIC MOMENT}

Episode two is the motoric moment. The conflicts between Sidima and Namhla and between Lizo and Zodwa arise in their forced marriages. Lizo and Namhla's arrogant behaviour is caused by their belief that they are tools used by the community to prevent them from getting married. Namhla and Lizo vow to free themselves from Sidima and Zodwa. Namhla insults Sidima and on the other side Lizo insults Zodwa. Act 2, Scenes 1 and 2 , demonstrate these violent confrontations.

Namhla: Ucikoza oku kanye kukaSathana!

Ndiyeke! Suka kum! Nja! Nja!

Indima I, Umboniso l:21

Namhla: You speak just like Satan! Leave me alonẹ!

Get away from me! Dog! Dog!

Act I, Scene 1:21

On the other side Lizo insults Zodwa:

Lizo: $\quad$ Ulixelegu elidla umongo wemihlathi. Ndikucebisa ukuba ndithi ndibuya ube sowuthuthile namanyala akho kulo mzi kabawo uyandiva?

Indima I, Umboniso 1:22-23

Lizo: You are as slovenly as if you eat the marrow of the jaws... My advice is that by the time I return you should have left my father's household with all your lewdness. Do you hear me? 
Zodwa, Lizo's wife, arrives in Johannesburg at Duma's room. Duma is with his girlfriend also by the name of Zodwa. Duma does not recognize Zodwa and Zodwa is surprised. Duma asks Zodwa where her husband Lizo is. Zodwa responds by referring to her husband as a monster. Duma introduces his girlfriend to Zodwa as Zodwa of Port Elizabeth. There is a knock at the door and Duma warns Zodwa who wants to respond to the knock not to answer. Lizo, disguised as a woman, bursts into the house, brandishing a gun. Duma takes out his gun as well but Lizo shoots first. Duma is killed by Lizo. Lizo demands money from Zodwa. Lizo asks if Zodwa is someone's wife. Zodwa of Port Elizabeth thinks that Duma is sleeping on the floor because he is drunk. Zodwa of Port Elizabeth wakes up and she is still drunk. She goes to Lizo who kills her mercilessly. Lizo asks Zodwa (his wife) where her husband is. Zodwa informs him that her husband is the one whom she has come to visit. Lizo says:

Umfazi sisivatho sendoda. Xa isivatho singahlambeki siyatshiswa!

Indima 2, Umboniso 3:28

A woman is a man's attire. If the attire cannot be cleaned, then it's burnt!

Act 2, Scene 3:28

Lizo switches off the light and shoots Zodwa, his wife. He is sure that he has killed her. He says:

Felani esonweni zihagundini

Die in your sins, you pigs
Indima 2, Umboniso 3:28

Act 2, Scene 3:28

Lizo kills Zodwa of Port Elizabeth as well, because he feels that to conceal the evidence he should kill the witness. He leaves and Sidima enters.

Sidima is shocked to see this blood bath. He wakes Zodwa up and is surprised by her presence at the place. Sidima stands next to Duma's body. They call the police. Zodwa and Sidima plan to travel to Swaziland thus leaving Duma and Zodwa of Port Elizabeth's bodies behind. They are positive that the bodies will be seen by police and the perpetrator will be punished. At Duma's funeral, the family think that they are burying Sidima. They wonder why Duma does not attend the funeral. There is a lot of confusion. 
It transpires from MaLimakhwe and Silumko's dialogue that Sidima and Zodwa are still alive. MaLimakhwe visits them in Swaziland and advises them to go back home to pay respect to the deceased. Lizo arrives at MaLimakhwe's place. MaLimakhwe asks him if he is not hurt by Zodwa's death. Lizo accuses Zodwa, his wife, of being the cause of the whole problem.

MaLimakhwe asks Lizo if it is true that Sidima and Zodwa had a child. Lizo tells her that it is true and that she died at Sidima's place. Lizo explains that he is not even bothered by so many things that are being said about him and Namhla. MaLimakhwe suggests that they get married. They talk lovingly about Namhla. It is clear that Lizo misses Namhla and is determined to marry her. He drinks a lot because of frustration.

\section{EPISODE 3: COMPLICATION}

Namhla chats with Vathiswa at her household. She is in a terrible state because of her difficulties. She feels lonely because she has no one in her life. Vathiswa reminds her that she does have parents and that moreover she has a lot of relatives. Namhla believes that her parents and her relatives are the cause of her miseries. Her terrible physical appearance she says, is the result of her parents' Actions.

Vathiswa reminds Namhla that all women suffer in this world, and she is not the first one. Namhla is still determined to marry Lizo against all odds. She says:

Zingavuka iinkqwithela, zingawa izichotho, ingagquma imilambo angadlokova Amaza, konke, konke, kobetha kudlule asale uLizo eliwele lam lomphefumlo Indima 3, Umboniso 1:46

Storms can blow, hail can fall, Rivers can be noisy waves can move swiftly. All these will come and go! And Lizo will be left behind as my soulmate.

Act 3, Scene 1:46

Vathiswa does not want to argue with Namhla anymore because she is stubborn. Vathiswa says: 
... Andixoxi mna noPhikisa-abakade-bebona

I do not argue with stubborn people.
Indima 3, Umboniso 1:46

Act 3, Scene 1:46

Namhla tells Vathiswa that it is only death that can separate her from Lizo. Namhla criticizes Vathiswa for not challenging traditional beliefs. She says:

Hlala wena Nosiko apho elalini, gqola, phulaphula ingoma yenkqatho.

Indima 3, Umboniso 1:47

Stay behind with custom beliefs in the rural areas, rust, and listen to the song of deceit.

Act 3, Scene 1:47

Vathiswa leaves Namhla and Lizo enters. They kiss. Lizo notices tears of joy in Namhla's eyes. They are clearly enjoying each other's company. MaNdaba, Namhla's mother-inlaw enters and she is furious to see Namhla with Lizo. She accuses Lizo of rejoicing at the death of their son Sidima. Namhla tells MaNdaba that her love for Lizo is deep. Namhla continues telling MaNdaba that the first stumbling block is removed and another one will follow suit.

Lizo and Namhla succeed in achieving their secondary objective in that they rid themselves of Sidima and Zodwa. Unfortunately their first goal has still not been reached by the time when Sidima and Zodwa are thought to be dead.

Namhla and MaNdaba argue. Lizo intervenes by asking Namhla to behave herself and not to worry because Sidima is dead. MaNdaba leaves and Silumko arrives. Silumko shows Namhla and Lizo the skin of a snake which has just been hidden by MaNdaba near their house, thus trying to bewitch them. Silumko informs them that he is aware that they want to get married and as such they must do something about the snake if they are serious in their objective. Namhla asks Silumko to elaborate on the issue of the snake's skin.

Silumko's response to Namhla's request shows that as a man he cannot reason with Namhla because she is a woman. His words symbolize the oppression and exploitation of women by men. Silumko says: 
Thula wena, ungumfazi into oyiyo.

Indima 3, Umboniso2:51

You keep quite, you are a woman.

Act 3, Scene 2:51

The portrayal of Namhla symbolizes suffering, exploitation and oppression of women by men.

Silumko instructs Lizo and Namhla to go and bury the snake's skin in Sidima's grave. Death, he says, is buried with another death. Lizo tells Silumko that he has long been telling Namhla that they must elope but they go as far as Port Elizabeth and then come back again. Lizo wants to pay Silumko, but Silumko believes that he should be paid after the results of the work done. Namhla and Lizo believe Silumko. Namhla says:

Ubuxoki ndingabukholelwa nje, le ibithethwa apha ndiyayivuma

Indima 3, Umboniso 2:53

I never believe lies, but I believe in the thing that was being said here.

Act 3, Scene 2:53

\section{EPISODE 4: CLIMAX}

Episode 4 is the climax. Namhla is in her room. She is frustrated and as the result she drinks a lot of beer. MaDlamini does not believe her daughter-in-law could behave so badly. She confronts her and Namhla responds by saying that she smokes too. MaDlamini slaps Namhla and pulls her by her hair. MaDlamini notices that Namhla is pregnant. She calls this a disgrace. Namhla tells MaDlamini that their child is joy and pride for them. She says:

Soze ndibe manyonywana ngalo mntwana. Ulihlazo kuwe, uliqhayiya kum, kuni usisiqalekiso, kuthi ulithamsanqeliso.

Indima 3, Umboniso 2:54

I'll never be ashamed of this child. It's a disgrace to you, but it's a pride to me, It's a curse to you, it's a blessing to us.

Act 3, Scene 2:54

As Namhla and MaDlamini are busy arguing, Nodabephi arrives. She has come to call Namhla and MaDlamini. They are needed by the Bhele men. Namhla wants to know if 
they will listen to her arguments. Namhla does not want to attend the gathering. She says that she will never part from Lizo. She explains that Lizo is her protection in a hostile world. She says:

uLizo likhakha lam

Indima 3, Umboniso 2:55

Lizo is my shield
Act 3, Scene 2:55

Clearly Namhla treasures life. She finds fulfillment in being Lizo's wife because it is her choice. She knows what freedom is and that it has a price. She thinks that what she wishes must be without sacrifice.

MaDlamini indicates one of the reasons for them to force Namhla to marry against her will. They want lobola for self-enrichment. MaDlamini says:

Yini na Namhla!. Yintoni kodwa mntwana wam! Ngesasitheni ke Bhelekazi? lingxaki nendlala azihlangatyezwa ngekhazi?

Indima 3, Umboniso 2:55

O Namhla! What's wrong with you my child! What could we have done

Bhelekazi. Problems and famine are prevented by lobola.

Act 3, Scene 2:55

In Act 1, Scene 4, there is a meeting of Bheles. Amongst the things they discuss is Namhla's pregnancy and that she must go for an abortion. Some of the men want to know who Namhla's boyfriend is. Namhla, Danile, MaNdaba and Vathiswa arrive. Qebeyi suggests that they apply the African custom isiko lokungena to Namhla. Namhla rejects the idea. Mphurhu replies:

Isiko lisiko, akuthandiswa wena

A tradition is a tradition, we are not begging you.
Indima 3, Umboniso 2:61

Act 3, Scene 2:61

The Bhele men warn Namhla about the wrath of ancestors if she does not co-operate. This is the third factor to hinder Lizo and Namhla's marriage. The Bhele and Cirha camps agree unanimously that an African custom should be imposed on Namhla. For instance, the Bhele and Cirha clans state: 
Namhla Bhelekazi, sikubizela into eqhelekileyo. AmaCirha anqwenela ukuvusa umyeni wakho ngomnye woonyana. Isiko lisiko akuthandiswa wena

Indima 3, Umboniso 2:61

Namhla Bhelekazi, we have summoned you for a common practice. The Cirha wish to resurrect your husband by marrying you to one of their sons ... This is a custom, and may not be opposed.

Act 3, Scene 2:61

The debate in the amaBhele meeting implies the existence of two conflicting camps, that is, the modern one and the traditional one. The modern group argues that Lizo is not rejected by Namhla, but by the male relatives. On the other hand, those who hold traditional beliefs claim that a custom cannot be destroyed by Christians. Sabatha, who represents traditionalists, says:

Akukho siko liza kuphanziswa ngamagqobhoka

There is no custom that will be destroyed by Christians.
Indima 3, Umboniso 2:62

Act 3, Scene 2:62

Violent arguments and disagreements between the modernists and traditionalists continue until the end of the drama.

Namhla refuses to marry Duma after the death of Sidima. As a liberated woman who believes in her values, she shouts at the traditionalists:

Nithi mandinikezele okwesibini ngomzimba wam endodeni nokuba uyala umphefumlo wam? Nalo inyala elivuyisa ababhubhileyo. Nango umkhuba oxolisa iminyanya!

Indima 3, Umboniso2:61

You say I must offer my body to the man for the second time even if my spirit does not allow it? That is a disgrace that pleases the dead, that is a bad tradition which reconciles the ancestors! 
The disagreement between the two camps that transpires from the above passage is also confirmed by the Cirha group. Ngxelelo says:

Oonokrawuzana bathi amaBhele azizibhaxa ezibini. Izifundiswa zithi makayekwe uMambhele azibonele, abengubo bona bathi isiko liyaziwa.

Indima 3, Umboniso2:67

Sources are saying that amaBhele are divided into two divisions. The educated ones are of the opinion that MamBhele should be allowed to decide on her own, the traditionalists are saying that the custom is accepted here.

Act 3, Scene 2:67

Namhla argues with MaDlamini and Danile who claim that they raised and educated her and as such she is supposed to obey them. Namhla bangs the door and leaves them.

Khulile informs the group that it is alleged that Zodwa Zazile, Lizo Vaxa's wife has eloped with a thug. They argue about educated people who allow their children to do as they wish.

The traditionalists still think that Namhla's behaviour is caused by the wrath of the ancestors. To rectify the curse, they therefore need to brew beer. Khulile reminds them that Namhla is baptized and as such she does not believe in ancestor worship.

\section{EPISODE 5: DENOUEMENT}

Episode 5 is the denouement. There is kind of reconciliation between the Christians and the traditionalists at the end of the play. They discuss ancestor worship and Christians quote from the Bible. They quote a passage from the Bible which advocates the isiko lokungena. There is a knock at the door and immediately thereafter Namhla enters violently. Having exchanged a few aggressive words with Vathiswa and Ngxelelo, she packs her belongings. She is crying painfully. The Bhele clan still feel that Namhla's behaviour is the result of the wrath of the ancestors. They pour beer at the door thus asking for forgiveness from the ancestors. Namhla kneels and prays. She then sings a song from church. The Bhele group still believe that Namhla's behaviour is caused also by 
Sidima's soul which they believe is not resting in peace. They now plan to go to the graveyard and ask for forgiveness.

Lizo and Namhla go to the graveyard with their faces covered. They go to a certain grave. Lizo anxiously asks Namhla if the grave is Sidima's. Namhla is sure that the grave is Sidima's. They put the snake's skin given to them by Silumko on the grave. Sidima and Zodwa arrive also. Their faces are covered. Sidima asks who they are and for whom they are looking. Namhla tells them that it's her husband's grave. Sidima asks Namhla who her husband is. Namhla tells him that it is Sidima and Sidima uncovers his face.

Lizo does not believe what he sees. He claims that he did die and that he was the first one to know about his "death". Sidima tells Lizo that he suspects that he is the one who killed Duma. Zodwa uncovers her face as well. She says:

\section{Akulibali Lizo ukrelekrele}

Lizo, you think that you are clever.
Indima 3, Umboniso3:82

Act 3, Scene 3:82

Sidima takes out his gun. He is ready to shoot. Zodwa takes out hers as well. Lizo draws his knife. Silumko arrives and tries to disarm everyone. MaNdaba arrives and pours a mixture of herbs on her son's grave. The Christian group arrives singing church hymns and holding the cross. The traditionalists are armed with their traditional sticks. After the song, MaLimakhwe looks straight at Namhla. She identifies Namhla as her child. Silumko points the gun at MaLimakhwe and Namhla. He is surprised that MaLimakhwe has a child. Namhla is excited to meet her mother. Zazile sees Zodwa and he is confused about what is happening at the graveyard. Silumko arrests all those who are armed. MaLimakhwe is also arrested. She does not understand what the cause for her arrest is. Gobinamba questions the cause of a man who arrests his own wife. Silumko comes nearer to the Christian group and joins their song.

It is evident from the above discussion that the protagonist camp does not achieve its goal.

\subsubsection{Analysis of plot structure}

The drama's plot structure may be evaluated according to various phases namely: 

a) Namhla and Lizo's meeting
b) Forced marriages go ahead
c) Killings by Lizo
d) Lizo and Namhla elope
e) The meeting of amaBhele
f) The graveyard scene

Certain incidents in Amaza's plot structure are not well orchestrated. Early in the play we are informed about the ups and downs of the two opposing camps: Namhla and Lizo, in the protagonists' camp and Sidima and Zodwa in the antagonists' camp. Lizo and Namhla harass their respective marriage partners. All of a sudden the author introduces the issue of Zodwa and Sidima's child. It is not clear what the aim of the introduction of the problem of the child is. This has no effect whatsoever in the development of the plot structure of the drama. Surely there is a lack of cause and effect in this incident.

Lizo's killings as well as the problem of identification is also not well motivated. He shoots Zodwa and utters the following words, thinking that Zodwa is dead:

Felani esonweni zihagundini

Die in your sins, you pigs
Indima 2, Umboniso 3:28

Act 2, Scene 3:28

One wonders why the author introduces the killings of these characters. This causes a lot of confusion because it does not even have an impact in the development of the plot. In the process, there is also the problem of identification. At Duma's funeral, the family thinks that they are burying Sidima. They wonder why Duma does not attend the funeral. There is a lot of confusion.

The discovery of MaLimakhwe, Namhla's mother, is not clear. It is not well motivated. At the graveyard, the Christian group and the traditionalists arrive. They sing church hymns and the traditionalists are armed with their traditional sticks. After the song, MaLimakhwe looks straight at Namhla and identifies her as her child. Silumko is shocked that MaLimakhwe has a child. There are no solutions to events in this plot structure. It is incidents like these that tend to mar the authors' works. 
Qangule's drama has strengths and weaknesses. One of his strengths in the plot structure is that of the portrayal of love between of Lizo and Namhla. In the very opening scene of the play, Namhla and Lizo are engaged in an intimate conversation professing their love for each other in contradiction to the forced marriage of Namhla to Sidima. The secret marriage heightens Namhla's resentment against Sidima while in contrast strengthening her love for Lizo. This drama artistically demonstrates the power of love and that love can conquer all as well as the inevitability of fate.

The portrayal of the co-existence of two cultures by the author can be regarded as a commendable success. Violent arguments and disagreements between the modernists and traditionalists which continue until the end of the drama are portrayed very well. These meetings imply the existence of two conflicting camps, that is, the modern one and the traditional one. At the end of the drama, no camp succeeds thus indicating that no culture should be imposed on another culture. One cannot help but commend Qangule for these skilful devices.

The scene at the graveyard is worth noting. Detective Silumko's expertise unravels hidden events. In this scene, "Sidima" and "Zodwa's" killers are not yet known. Silumko uses liquor to get information from Lizo, who ultimately tells them that he is the potential killer of "Sidima" and "Zodwa" because he loves Namhla.

This counterplot contributes to the outcome of the main plot by opposing events. These are revelations at the graveyard, Sidima and Zodwa are not dead, Lizo and Namhla never become husband and wife as they wished.

\subsubsection{UFeziwe okanye inkohlakalo (D.T. Mtywaku, 1982)}

\subsubsection{Episodes}

\section{EPISODE 1: EXPOSITION}

In the expositional episode, Act I, scene I, Mtywaku introduces characters who will instigate conflict on which theme and intrigue is based. The play is dominated by the cruel, oppressive and sadistic Actions on the part of two characters, Kwedinana and 
Nowikithi. The different social conditions from which the characters emerge imply a conflict, which may be ascribed to the clash of traditional and modern ideas.

In Mtywaku's play, the geographical context is identified as Nkqonkqweni village. Feziwe, the main character, is a daughter of affluent parents. Her father is dead. After the death of her husband, MamCirha is left with her cruel relatives, Kwedinana, Nowikithi and others. These relatives, Kwedinana and Nowikithi in particular, regard themselves as overseers in MamCirha's household. All of a sudden MamCirha finds herself no longer in charge of her own home.

It emerges from MamCirha's dialogue that her daughter Feziwe is educated and MamCirha educated her daughter against her husband's will. Nevertheless, MamCirha does not blame him because according to the traditional beliefs, a woman is not supposed to be educated. MamCirha says:

...Andimgxeki uDlomo kuba wayengazenzisi kuba wayegxekwa ngamawabo embona ubutyhakala ngokulahla imali efundisa ibhinqa

Indima I, Umboniso I:1

... Dlomo is not to blame because he could not help it as he was criticized by his relatives for educating a woman.

Act I, Scene I:1

MamCirha's life, especially after the death of her husband, reflects the oppression of women, especially widows in this case. Kwedinana arrives at MamCirha's home and in his conversation, he reminds her that now that her husband is dead, he is the head of her family. He says:

Ndiyabona ukuba akukaqondi ukuba ndim ngoku inkunzi kulo mzi kabawo.

Umkile ngoku laa va ngomfazi ungumkhuluwa esasigqib'apha naye kuse ngomso ethetha phaya.

Indima I, Umboniso $1: 2$

I see that you do not understand yet that I am the head of my father's household. My elder brother, the one who used to be bullied by a woman, is gone. 
We used to make decisions on certain issues but on the following day he used to come back with other ideas.

Kwedinana continues bullying MamCirha by telling her that he is going to force Feziwe, her daughter, to marry. He further tells her that Feziwe is a girl and as such she must get married. MamCirha reminds Kwedinana that times have changed and as such forced marriages are outdated. MamCirha further tells Kwedinana that she did not challenge him when he took her husband's cattle by force because she has no one to look after the cattle. Fuzile, MamCirha's son left home long ago and now Kwedinana accuses her of witchcraft in chasing Fuzile away from home (ukuphephetha). Kwedinana further accuses MamCirha of killing her husband by bewitching him. It is common belief in African culture that if a man dies he is bewitched by his wife. Because Kwedinana threatens to force Feziwe to get married, MamCirha threatens to report him to the headman if her daughter does not come back from work.

MamCirha goes to the headman's place to report Kwedinana. Fudumele, the headman's neighbour, is also at the headman's place upon MamCirha's arrival. He reminds MamCirha that they have long been telling her to report Kwedinana whenever he bothers her at her home. MamCirha informs them about Kwedinana who plans to force Feziwe to marry against her will. The headman and Fudumele assure MamCirha that they are going to stop Kwedinana.

In Scene 3, Kwedinana tells his wife Nowikithi that MamCirha reported him to the headman about Feziwe's planned forced marriage. Nowikithi who is a staunch supporter of her husband feels that is none of the headman's business. They feel that according to their custom, it is a family affair. Nowikithi encourages her husband to go ahead with their plan of forcing Feziwe to get married. Kwedinana and Nowikithi look down upon Feziwe. They even use derogatory names like Dingiwe when talking about her. This word means the one who has no husband and they use it in a very derogatory manner. Kwedinana and Nowikithi's problem is their daughter, Nomathamo, who likes Feziwe. They feel that Feziwe has a bad influence on Nomathamo. Nomathamo's parents are well informed about Feziwe's love affair. They know that Feziwe is in love with a man from Queenstown. On the other hand, they plan to force her to marry an old man of the Khomazini clan. They plan to tell the family members of the Khomazini clan to take Feziwe by force. 
For the other aspect of injustice against women, MamCirha, the widowed character, is suffering because of the oppressive custom where a widow cannot inherit her husband's land, for it must pass on to his sons or a senior male descendant.

In Scene 4, Nomathamo visits Feziwe at her home. She informs Feziwe about her mother who burnt the dress she gave her into ashes. Feziwe tries to calm her down. Nomathamo continues telling Feziwe that her parents dislike their friendship. They suspect that Feziwe is going to influence their daughter badly concerning the marriage issues. Feziwe explains to Nomathamo, that she understands her parents reasoning because they still belong to the old times. They do not realize that times are changing. They are traditionalists. Feziwe says that even her late father used to be like that but her mother was patient enough to change his beliefs. Feziwe's father chanced despite severe criticism by his relatives. She says:

...Abakuqondi ukuguquka kwamaxesha, basabophelelekile kumasiko nezithethe zookhokho.

Indima I, Umboniso 4:8

... They do not understand that times have changed; they are still bound by our outdated ancestors' customs and traditions.

Act I, Scene 4:8

From the above passage, it is clear that Feziwe advocates change, hence the uttering of the following words:

Dlomo, andiyithandabuzi le nto ndiyithethayo. Amaxesha ayaguquka; zimbi kwizithethe zookhokho ziyaphelelwa

Indima I, Umboniso 4:9

Dlomo, I do not doubt what I'm saying. Times change - some of our ancestors customs and traditions are outdated. 
MamCirha's in-laws continue ill-treating her and Feziwe. Kwedinana, one night, demands that they open the door for him because he is the head of their family in the absence of MamCirha's husband. He is drunk and he shouts:

Feziwe, vula. Kuqale nini ukungabikho ndoda ekhay'apha? Akwazi ukuba nguyihlo uSthombo yedwa obhubhileyo? Vula, Feziwe, nguKwedinana lo umakhonya kulo mzi kabaw'omkhulu.

Indima I, Umboniso 5:10

Open Feziwe. Since when is there no man in this house? Don't you know that it is only your father Sthombo who passed away? Open Feziwe, this is Kwedinana, the boss in this house of my father.

Act I, Scene 5:10

MamCirha is deeply disturbed by this rude behaviour and bad treatment by Kwedinana. She goes to church on the following day to pray and she is not feeling well at all. She is weak. Feziwe is concerned and that comes out clearly in her soliloquy:

UCirhakazi uzinyanzele wawela namhlanje. Imeko yempilo yakhe iya isihla ngokuhla. Phofu ibinokuthini xa engazange afumane nethuba lokuzilela utata ngokuzola? Seloko wemkayo utata uhlalele ukubonela impahla yakhe ithuthwa ngamaqela ngamaqela.

Indima I, Umboniso 5:11

Cirhakazi forced herself and crossed the river today. I thought she was not going to attend the church service today. Her health condition is deteriorating, day by day. Why wouldn't it deteriorate? After all she never got time to mourn the death of my father peacefully. Ever since our father left us she is witnessing her belongings being taken away from her bit by bit.

Act I, Scene 5:11

MamCirha passes away suddenly and Feziwe is devastated. After the death of MamCirha, Feziwe is left with her cruel relatives, Kwedinana and Nowikithi who abuse her. 


\section{EPISODE 2: MOTORIC MOMENT}

Episode 2 is the motoric moment. In this episode, Feziwe is supported by Nomathamo, Kwedinana's daughter. She comforts her in all her sorrows. Nomathamo reminds Feziwe that Kwedinana, her father is serious about going ahead with their plan of forcing her to get married. Feziwe does not believe that. As an educated girl, she feels that they cannot violate her rights and if they try, she can sue them. Fezivve's portrayal symbolizes modern people, people who reacts according to their feelings and whose decisions are based on their beliefs.

Feziwe goes to fetch water from the river, not knowing that Kwedinana has already arranged that she be dragged (ukuthwala) by men to her "husband-to-be's" home. Two men, Silimela and Phuzi try to take her by force. Feziwe and Nomathamo defend themselves and the plan is aborted for that period. Having realized that Nomathamo was with Feziwe at that time, Kwedinana confronts her.

Feziwe decides to write a letter to her lover, Thandile. She decides not to tell him about what happened to her.

Ultimately Kwedinana decides to go to Feziwe's home with two men and they open the door forcefully. Feziwe is taken by force to her "husband-to-be" and they cause a lot of damage at her home. Thereafter, Kwedinana does not even bother himself by checking if Feziwe's belongings at her home are safe. Nomathamo is concerned about Feziwe's position. She feels that this cruelty needs the response of Feziwe's brother, Fuzile, because Feziwe has no one else to protect her. Nomathamo is worried also about Feziwe's boyfriend who knows nothing about Feziwe's problem. Her serious problem is that she cannot even write properly. She is illiterate because her traditionalist upbringing undervalues educating women.

Nomathamo collects Feziwe's clothes and in the process, she sees Feziwe's letter which is addressed to her boyfriend, Thandile Manka. Though Nomathamo cannot write properly because she was still being taught by Feziwe how to write, she decides to write Thandile a letter and explain what happened to Feziwe. She then decides to mail both letters. 
Apparently Thandile Manka does receive the letters. He decides to visit Feziwe so as to get more clarification on this issue. He is fetched by Nqaba. Having heard the story, Thandile thanks them. He informs them that he will be working as a lawyer in Umtata.

In Scene 6, Nomathamo visits Feziwe at her new home. Feziwe is in a terrible state. She looks differently and she is busy grinding mealies for her in-laws. Feziwe is frustrated. She does not eat nor drink, nor does she sleep at night. Feziwe tells Nomathamo that her "husband" is seriously ill and he can die at any moment. She says that he is even older than her own father. Feziwe complains that her in-laws are traditionalists. She thinks that even if the old man can die they will induce her to accept a consort for the purpose of keeping alive the marriage between her and her late husband's people. This custom is known as the levirate custom (isiko lokungena).

Feziwe's husband becomes seriously ill and, while everybody is busy looking after him, Feziwe gets a chance of going home. On her way, she prays to God for protection until she reaches her home. When she arrives home, she is shocked to find that goats sleep inside the houses and everything is in disrepair. Her home is in a mess. A certain boy by the name of Zimba, sleeps at Feziwe's home. Feziwe warns Zimba not to tell anyone that she is back. The only person who can be told is Nomathamo. Nomathamo secretly visits Feziwe and brings her food. Nowikithi asks Nomathamo if Feziwe is back. Nomathamo feels that Feziwe is supposed to tell her boyfriend that she is back. Feziwe does not share Nomathamo's suggestion. She is still embarrassed by her terrible appearance and furthermore as a Xhosa woman she is supposed to be proud and not invite or entice a man. Feziwe says:

...njengentombi: yomXhosa ezidlayo andinakho ukulikhweba isoka

Indima I, Umboniso 4:37

... as a proud Xhosa girl I cannot invite a man

Act I, Scene 4:37

From what is being said by Feziwe one identifies deeply rooted African traditions despite her more modern upbringing. Feziwe is a teacher by profession and as such is liberated, but still she believes in women African pride values.

Fuzile, Feziwe's brother, arrives. Nomathamo and Feziwe explain everything to him. Immediately thereafter Fuzile goes to Kwedinana's home to confront him about the way he 
is busy destroying his home. The two evil characters, Kwedinana and his wife, Nowikithi are shocked to see Fuzile. They realize that things will now change.

\section{EPISODE 3: COMPLICATION}

Episode 3 is the complication. Ngwenya and Phuzi arrive at Feziwe's home not knowing that her brother Fuzile is home. They remark that she does not look like a married woman. Fuzile summons his relatives in order to get clarity on Feziwe's issue of a forced marriage. The two men Phuzi and Ngwenya complain about lobola cattle, which are already paid. Fuzile explains that the man to whom they paid lobola is Kwedinana and he and his sister have nothing to do with their lobola.

In the meeting between Kwedinana, his relatives and Feziwe's in-laws, Fezile tells Kwedinana that by forcing Feziwe to get married, he was abusing her. He demands that lobola cattle accepted in the name of Feziwe must be returned to their owner. Kwedinana is furious and he vows to get him one day:

... Kodwa sakuze sihlangan' enkungwini sobabini

Indima I, Umboniso $8: 47$

... I will get you in the mist one day and it will only be the two of us

Act I, Scene 8:47

Kwedinana does not believe that he is wrong. It is evident that he and his wife Nowikithi are not only under the influence of old African tradition, they are cruel as well. Sirayi (1993:95) suggests that in the title uFeziwe okanye inkohlakalo, Mtywaku names the theatre of cruelty from which his characters emerge. Furthermore, he elaborates, the attributes of some of the major characters in the play are suggested in its title, where inkohlakalo means "cruelty". This therefore makes one expect evil characters.

Kwedinana wants to revenge himself on Fuzile for destroying his plans. He is, however, afraid of Fuzile's gun. Kwedinana tries to find out if Fuzile will not be going back to his work. 
Nowikithi is very domineering. She is always advising her husband on his evil plans. She is always very crude when speaking to Kwedinana. Since Fuzile proves to be a threat to their evil plans, Kwedinana relies on his wife for advice. Kwedinana says:

Makhe ndidibane noWikithi imazam, ikhe ... indithe umoya ndiphelelwe okwevili eligqabhukileyo.

Indima I, Umboniso 8:49

Let me meet my wife Nowikithi so that she can advise me. I am finished like a flat tire.

Act I, Scene 8:49

Nowikithi is angry. It transpires from her dialogue that she does not believe that her household is run by a boy, that is, Fuzile. As a traditionalist she believes that decisions are supposed to be taken by elders, that is Kwedinana and herself. Nowikithi believes that elders cannot be challenged by a boy. That is why she and Kwedinana decide to go ahead with Feziwe's arranged marriage. Moreover, they want to enrich themselves with Feziwe's lobola.

Nowikithi too is also afraid of Fuzile's gun. Kwedinana is devastated because Nowikithi is his last hope. He says:

Ndiyancama ke ngoku xa uNowikithi abesoloko endikhuthaza endifutha esuka ankwantye enjenje. Kuya kufuneka ndihlenge.

Indima 2, Umboniso 8:51

I have now given up because Nowikithi on whom I relied for encouragement is frightened. I must try different plans.

Act 2, Scene 8:51

Things become complicated more and more. Fuzile demands his father's cattle from Kwedinana because he wants to do a traditional cleansing ceremony for his father. Fezile's relatives are excited that he is still keeping his customs and traditions. Mpheko says:

Ndiyavuya, Dlomo xa kuthe kanti isiko akulishiyanga ezintlangeni 
I am glad Dlomo to realize that you are still keeping your custom and you did not leave it with various tribes.

Act 3 , Scene 9

Fuzile and Feziwe's wishes are successful. They performed their parents' ceremonies.

Feziwe has now been working for two years in Pietermaritzburg as a nurse after deciding to change her career. As she is busy writing letters to her nephews, she meets her boyfriend Thandile by surprise. This is a pleasant surprise indeed for her. They go to a friend's place and they enjoy each other's company after such a long time. Thandile lovingly calls Feziwe "Ophe". Feziwe tells him about everything that happened in her life. Thandile proposes marriage to Feziwe. Feziwe accepts the proposal.

Fuzile receives a letter from Feziwe informing him about negotiators (oonozakuzaku) who will be visiting them at home. Fuzile calls his relatives immediately because according to African culture he cannot discuss marriage negotiations alone.

\section{EPISODE 4: CLIMAX}

Episode 4 is the climax. Having heard of Feziwe's coming marriage, Nowikithi and Kwedinana are devastated. Apparently Kwedinana did not attend the meeting at Fuzile's home. He is now frustrated because he will be in the dark in as far as marriage arrangements are concerned. They refer to Feziwe's fiancé as a white person because he has a car. Nowikithi remarks:

NgumLungu, mpela! Unayo nemoto?

He is really a white man! He even has a car?
Indima 4, Umboniso 4:62

Act 4, Scene 4:62

Kwedinana and Nowikithi plan to kill Feziwe's fiancé. They decide to hire assassins Skelem, Sikhohlakali and Ngcwangu to do the dirty job for them. In literature naming is one of the crucial modes of character delineation especially in African literature. Names sometimes identify a character's attributes. Sirayi (1993:93) suggests that "naming as a literary technique is the oldest which is culture bound in the African context". The names of Kwedinana's assassins depict their characters. Their names depict their cruelty and aggressiveness. 
In Scene 5, we are introduced to Fuzile's friends and relatives who celebrate the arrival of their brother-in-law, Thandile. Thandile and Feziwe plan to marry after Feziwe has finished her studies. Present are Mpheko, Thandile, Fuzile, Ncumisa, Nqaba and Nomsa. Thandile plans to leave on the following day.

At Kwedinana's place, plans of assassinating Thandile are at an advanced stage. The three assassins panic because they do not see Thandile's car. Ultimately Thandile's car approaches them. Skelem lies down in the middle of the road. Thandile decides to stop, thinking that it is someone who is in trouble. They murder him mercilessly.

Fuzile is restless at home because he sees lights of the car and he suspects that it could be Thandile's car. He is always suspicious of Kwedinana's hidden agenda. They decide to go and investigate only to find that Thandile is murdered. It takes time for them to have courage to tell Feziwe. When Feziwe receives the bad news she is devastated.

The three assassins are convicted after a month. Kwedinana promised to hire a lawyer for them, but he never honours that promise. They plan to kill Kwedinana. Skelem disappears from jail to kill Kwedinana. He knocks at Kwedinana's door and pretends to be Sompempe. Kwedinana opens the door and murders him. He collapses saying:

uSkelem undigqibile

Skelem has finished me

At his death, Kwedinana says:

Fezi-we-ndi-yiha-mbi-le indle-la. Ndifi-ki-le esi-phe-Iwe-ni. Inko-hla-ka-lo indi-fume-ne ndi-fa-ndi-yi-nkwa-mba

Indima 4, Umboniso 4:76

Feziwe, I have travelled this way. I have arrived at the destination. Cruelty has rebounded on me. I am dying defenceless.
Indima 4, Umboniso 4:76

Act 4, Scene 4:76 


\section{EPISODE 5: DENOUEMENT}

Episode 5 is the denouement. Feziwe seems to have recovered from shock. Nevertheless, she is still sad because she is still speechless and is suffering from the loss of appetite. Feziwe drinks poison. Nomathamo, having realized that Feziwe is dead, drinks poison as well. Nomisa, Fuzile's wife, is deeply shocked. She mourns the death of her two sisters-in-law. Fuzile, Nowikithi and Zinto arrive. Fuzile tells Nowikithi that these deaths are the results of their cruel deeds. He tells her that he is sad that Kwedinana did not live longer to witness the results of his evil deeds. Fuzile says that Kwedinana and Nowikithi thought that they were punishing Feziwe, not knowing that in the process their family would be affected as well.

Nowikithi also commits suicide out of frustration. The deaths of Kwedinana and Nowikhithi, Sirayi (1993:120) suggests, might be regarded as a punishment meted out by the ancestors because of the couple's cruelty.

\subsubsection{Analysis of plot structure}

Roberts (1992:51) explains that:

Fictional and dramatic characters are derived from life, and so are the things that they do. These things are the actions or incidents, which occur in chronological order. Once we have established a narrative or sequential order, however, there is still more to be considered. This is plot, or the plan of development of the actions.

Furthermore, Roberts (1992:51) observes:

Without a plot we do not have a story or drama. In a well-plotted work, nothing is irrelevant, everything is related.

Roberts (1992) is apparently one of the scholars who argue strongly for the view that to have a plot, a sequence must be integrated with human motivation. 
My critical commentary on the plot structure of Mtywaku's drama focuses primarily on the fact and dramaturgical matters:
a) The abuse of MamCirha and her death
b) The abduction and escape of Feziwe
c) The return of Fuzile and the return of the lobola cattle and his own father's cattle
d) The meeting of Feziwe and Thandile in Pietermaritsburg and their plan to marry
e) The murder of Thandile and Kwedinana
f) The suicide of Feziwe, Nomathamo and Nowikithi

The manner in which Mtywaku has handled some of the above matters led to a very poor plot structure. The first two phases, that is the abuse of MamCirha and her death as well as the abduction and escape of Feziwe are well orchestrated. These two major elements of the plot are brought out to emphasize the plan of conflict in the play. One identifies Mtywaku's use of chronological order which is so important, not because one thing happens after another, but that it happens because of another. It is response, causation, interaction and conflict that make a plot out of a series of actions. There is unity of action because of the connected events. This is a means to enhance compactness, coherence and effectiveness in the drama. One cannot help but commend Mtywaku on applying this technique. He seems to be conversant with the fundamental question to be answered in plot structure such as to explain why things are where they are and why this here and not there. This method is only one way of structuring the Actions.

However, the sudden return of Fuzile is not well orchestrated at all. So is the return of the lobola cattle and his father's cattle. Mtywaku seems to be aware of the fact that Actions that are unified are closely related to the main idea or theme in the drama. He decides to allow Fuzile to come home at once so that he can claim the lobola cattle from Kwedinana thus enforcing the theme of injustices against women.

Thandile's role is also not clarified. Nomathamo does write him a letter, explaining Feziwe's predicament, especially the issue of the forced marriage. Why is he not jealous of his lover and fight for her? One suspects that the playwright wants to prove beyond doubt how Feziwe is ill-treated by Kwedinana. He wants them to treat her in the most cruel manner that has ever been witnessed because even the title of the book is $\underline{\mathbf{u F e z i w e}}$ okanye inkohlakalo. Thandile does absolutely nothing about Feziwe's abduction. Having 
done nothing about Feziwe's abduction, he then meets her by chance in Pietermaritzburg. He becomes excited and demonstrates that he is head over heels in love with her and yet he did not bother himself about helping her when she was abducted.

There is an over-exposure of the aspect of cruelty in this drama. The author seems to be carried away by the wider issue of injustices against women and in this process he completely forgets about the characters and the events in the plot. He wants to focus attention exclusively on such injustices and thus he even kills all the good people. He reinforced this aspect by concentrating on killing family members: Feziwe, Nomathamo; Nowikithi, and Thandile.

Mtywaku's portrayal of change in tradition is unskilled. He even mentioned ukungena (the levirate custom) as a deterrent although it never happens in the drama. He deliberately handless other aspects of culture like ukuthwala, ukungena and lobola so badly in order to influence the reader to accept change.

It is also not clear why Thandile and Kwedinana are killed. It transpires from Kwedinana's stagey words on his death that Mtywaku is preaching and exaggerating injustices against women. There is a lot of blood in this drama because later on even Feziwe, Nomathamo and Nowikithi commit suicide. It is also not clear even in this instance why Mtywaku decides to remove all these characters. Sirayi (1993:120) can only suggest that:

... this may be regarded as a punishment meted out by the ancestors because of the couple's cruelty.

The above cited factors lead to a very poor structure in Mtywaku's drama.

\subsection{THEME}

In Jongilanga's drama, the author deals with the theme of abuse of women. The protagonist Novayithi is abused by her husband Solani. They are struggling to survive financially and as a result they are forced to beg for food from their neighbours. Novayithi's husband makes it clear that she is the one who is supposed to go about begging for food, while he enjoys himself by going around from shebeen to shebeen, in a constant state of drunkeness. If Novayithi does not get food, then her husband blames her 
for not doing her job properly. Solani does not want to look for a job. Novayithi's neighbours advise her not to give her husband food so that he can go and look for a job. Unfortunately Novayithi will not listen. Sometimes Solani abuses his wife Novayithi physically by beating her. Even when Novayithi decides to go to her parents, Solani is not serious about going to her home to fetch her.

Ultimately he asks his friends to accompany him to Novayithi's home to fetch her. We note an indirect form of abuse even when he decides not to go back and fetch Novayithi. That he does not fetch her, indicates that he does not respect her. When, on his first visit, Novayithi's family demand payment as a form of punishment, Novayithi decides to go back to her household for the sake of the children who were really struggling during her absence. Novayithi is abused by her husband again when he gets a job in East London. He does not provide her with anything and to make matters worse, he comes back home with a girlfriend who claims to be his wife. Novayithi decides to fight back by throwing boiling water at them.

Qangule's Amaza is concerned with the theme of forced marriages. Namhla loves Lizo but her foster parents force her to marry Sidima whom she does not love. The drama hinges on the dangers and consequences of forced marriages. The author's work demonstrates not only a clash of cultures between modernists and traditionalists but also the spectre of patriarchy, which contributes to constraints of women's freedom in the choice of marriage partners as well as autonomy.

Namhla's condition and behaviour deteriorate after having been denied freedom of choice by her foster parents. She becomes an alcoholic and a heavy smoker. The problems and dangers of a forced marriage are depicted and illustrated also in Mtywaku's uFeziwe okanye inkohlakalo.

In uFeziwe okanye inkohlakalo, the author begins showing the dangers of forced marriages from the title of the drama itself. The title, means, "Feziwe or cruelty". It is evident from the title of the drama that Kwedinana, Feziwe's uncle is determined to force her to marry against her will, failing which she must bear the cruel consequences thereof. After the death of Feziwe's mother, Kwedinana forces her to marry someone whom she does not love. In fact he makes this demand even when her mother is still alive because he sees himself as an overseer of Feziwe's home upon the death of Feziwe's father. He 
ignores MamCirha, Feziwe's mother, because she is a woman. MamCirha has no voice in the affairs of her household and one is tempted to assume that it was this thought of being objectified that breaks her heart and causes her death.

Feziwe loves Thandile, but Kwedinana and his wife force her to marry someone else to enrich themselves. She experiences cultural silencing and subordination because she is not expected to marry someone of her choice, but rather to be submissive to the demands of the senior members of her extended family.

\subsection{EVALUATION}

In their plot structure, dramas of this period have strengths and weaknesses. Seemingly, going along with women oppression has been an unfortunate and painful reality of our life in this land that it has caused a deep wound. Certain incidents are not well orchestrated. It is these incidents that mark the authors' works. Qangule, in his drama, Amaza is commendable because of his artistic portrayal of constant love between Lizo and Namhla. His skilful portrayal of the co-existence of two cultures is brilliant. His plot structure has strengths and weaknesses because of certain confusing and unmotivated incidents like that one of the sudden discovery of MaLimakhwe, Namhla's mother.

Just like the dramas of the first period, which are under study, there is also an overemphasis of injustices against women. They also do this at the expense of their plot structures. Mtywaku's portrayal of change in tradition in his book uFeziwe okanye inkohlokalo is unskilled. He deliberately handles other aspects of culture in order to influence the reader to accept change.

In Ubusuku obungenanyanga, written by Jongilanga, plot structure is also badly influenced by his exaggeration of portraying women as victims of patriarchy. His characters are portrayed as they are for dramatic effect. Novayithi, for example, is one such character. She is always abused by her husband, Solani, causing miseries in her life up to the end of the drama.

Solani even abuses his wife physically. The last cruel thing he does is to bring his girlfriend with whom he lived at work in East London to Novayithi's household, introducing her as his wife. Meanwhile, all those years Novayithi was sweating to make ends meet at home and to keep the fire burning. 
In both Amaza and uFeziwe okanye inkohlakalo, the problem is forced marriages. In Amaza Namhla is forced by her foster parents to marry someone she does not love. She is forced to agree because she cannot challenge her father according to customs and traditions. So is the case in Mtywaku's drama. Feziwe is suffering. Upon the death of her parents, she is forced by her cruel uncle Kwedinana to marry someone she does not even know. Feziwe is forcibly carried off by men to her husband-to-be's home (ukuthwala).

The plot structures of these dramas also do have weaknesses. This is caused by emphasizing certain aspects of culture in order to influence the reader to accept change. 


\section{CHAPTER 4}

\section{PLOT STRUCTURE IN THE THIRD LITERARY PERIOD (1988-1997)}

\subsection{AIM}

The plot structure of the four dramas which have been selected from this period will be analyzed in this chapter. The themes of these dramas will be examined and an evaluation of these four dramas will then be given.

Lastly, a comparison will be drawn on certain aspects of all ten dramas within the three periods, that is, a comparison of their plot structures and themes as well as an evaluation of these dramas.

\subsection{PLOT STRUCTURE}

\subsubsection{Emgxobhozweni (B.B. Mkonto,1988)}

\subsubsection{Episodes}

\section{EPISODE 1: EXPOSITION}

Episode one, which is the exposition, commences with Vakele in his shop. $\mathrm{He}$ is busy counting his money and the weather outside is cloudy and about to rain. The weather must be supposed to be ominous. Vakele reminds No-ankile, his wife, that she is supposed to count money in their shop and then deposit it at the bank immediately. Noankile explains that she wants to show Vakele that there is no profit in their shop anymore. They quarrel and exchange words. It transpires from No-ankile's speech that all is not well between her and Vakele's daughter, Nomonde, by the first wife. No-ankile says:

Sendakufunda ukuba ukuze umntu avane nawe makathethe kakuhle ngesimo sentombi yakho.

Indima I, Umboniso I:2

I discovered long ago that if one wants to be on good terms with you then one must say good things about your daughter, Nomonde 
Conflict between the main characters is clearly suggested in No-ankile's speech. The playwright begins his drama with a brief identification of characters to be analyzed and this is followed by reference to noteworthy problems in determining the characters' qualities. The element of tension comes from No-ankile's efforts to stop her husband from supporting his daughter, Nomonde. No-ankile's words create tension because they raise an expectation of another possible confrontation between her and Vakele. He tells Noankile that he respects Nomonde because she is a hard worker. No-ankile keeps on blaming Vakele for allowing people to exploit them in their shop. Vakele is not prepared to be separated from his daughter. He goes to work and tells No-ankile to open the shop because it is teachers' pay day. No-ankile talks to herself. She thinks that she must do something about Vakele's stubbornness because he is still impossible and difficult. He does not want to succumb to her demands. No-ankile says:

...Bendithi ndiyigqibile! Ndimbonile ngoku apho akhoyo, kuza kufuneka ndibhinqele phezulu. Uyazi ukuba ndiphantse ukulala... Indoda le ithi mna, nomzi ngowam! Ndim kula mnyango, ndim entla!

Indima I, Umboniso 1:4

...I thought I finished him! I've seen his stand, I must pull up my socks. You know I nearly fell asleep ... The man is mine, and the household is mine! It's me at the door, it's me on the north.

Act I, Scene 1:4

Mkonto's first episode (exposition) is an effective introductory episode. His remarkably adroit exposition of the opening of the play is predicted upon the actions and reactions of his characters, each with her own set of attitudes and goals. The dramatist has handled his characters' dialogue artfully. The dialogue between Vakele and No-ankile is characterized by action and reaction which is the physics of drama.

No-ankile is visited by MaNdungwane. MaNdungwane complains about her husband who looks down upon her. No-ankile informs MaNdungwane that all men are like that so she is not the only one who is suffering. They talk about Vakele who used to be submissive. Noankile remembers the good old days she used to share with Vakele while his first wife was still alive. No-ankile and Vakele used to love each other, but now things have changed. They talk badly also about Nomonde, Vakele's daughter from the first marriage. No-ankile 
tells MaNdungwane about her marriage problems, MaNdungwane tells her not to worry because it is now time for women. MaNdungwane says:

Mus'ukukhathazeka Tshezi maan, sikho mfazi, kwaye ngoku ixesha lelethu bafazi, masiphathisane

Indima I, Umboniso I:6

Do not worry Tshezi maan, we are with you, lady, and moreover now is the time for us women, let us help each other.

Act I, Scene I:6

MaNdungwane and No-ankile plan to tear the relationship between Vakele and his daughter apart. The plans of the two characters definitely strengthen the development of the story.

\section{EPISODE 2: MOTORIC MOMENT}

Scene 2 concerns the meeting between Nomonde and her cousin Sizeka. They talk about Sizeka who cannot go to work because her eye is injured. Their conversation leads to the discussion of No-ankile. It is clear that they hate her. They criticize No-ankile for not having a marriage name given by in-laws. They are interrupted in the discussion by "Bra Tebro" of Alice. Nomonde leaves with her boyfriend "Bra Tebro" and Sizeka is left behind until Gogo, the helper arrives. Sizeka envies Nomonde for having a love relationship.

Scene 3 takes us to Sizeka's place, Number 59 Amos Street in Alice. Sizeka is resting and talking to herself. Hombakazi arrives. They talk. Sizeka tells her mother that they must expect her guests at her home on the following day. Those guests are Sizeka's marriage negotiators. As they are busy talking about Sizeka's guests, Nomonde arrives. Sizeka explains to her mother that her boyfriend told her that he will be sending people to her home very soon. Nomonde gets excited and congratulates Sizeka.

Vakele and Hombakaz, his sister arei at the shop. Vakele is excited to see his sister. He tells her that he has been missing her because he is experiencing problems which cause him to lose his manhood status and power. It is evident he is referring to his problems with No-ankile. 
Hombakazi informs Vakele that she has good news about Sizeka. The good news is that on the following day, marriage negotiators (oonozakuzaku) would be visiting Sizeka's family. Hombakazi does not look happy at all because her husband is stingy. Moreover, Hombakazi is afraid of her husband because he is too talkative. She wants to be accompanied by her brother Vakele. Hombakazi says:

Ukuba ubungaxakekanga ngendisithi ndikhaphe ze seluzibeka ngokwakho ezi ngongoma.

Indima 2, Umboniso 4:22

Had it not been for the fact that you are busy then I would ask you to accompany me and explain everything to him.

Act 2, Scene 4:22

Hombakazi explains that she cannot argue with her husband because she is a woman. Vakele wishes that his wife No-ankile would behave the same way as his sister. Vakele voices out his concern about No-ankile's bad behaviour lately. Hombakazi's bad dream about Vakele's first wife, Majola with Nomonde on her back, frightens his family because No-ankile appeared in the dream also, chasing them with an axe. This dream is symbolic. It symbolizes No-ankile's evil plans against Nomonde and Vakele. Vakele believes that the dream has something to do with No-ankile's tricks. Conflicts between Vakele, Noankile and Nomonde are well-chosen by the dramatist because they provide many possibilities for the development of plot as well as the early point of attack. The conflict among these characters is the source of much tension.

Having heard about Vakele's rocky marriage, Hombakazi finds herself guilty because she is the one who forced Vakele to get married after the death of his first wife. Vakele was not ready then. Vakele respects No-ankile because she is very good in business, but he suspects that she is misusing money because he does not see any profit. When Vakele tries to find out what the problem could be, then No-ankile simply put the bag of money on the table saying that he must count the money himself. Hombakazi suggests that Vakele must keep an eye on No-ankile. She advises him to draw up a will for Nomonde's sake because anything can happen as seemingly No-ankile's illicit behaviour grows with no limits. 
Scene five opens with No-ankile sitting with Vusinja and Phindile at her home. They talk about dance and their girlfriends. Apparently Vusinja has been called by No-ankile. Vakele has gone away to look for sheep to be slaughtered at the ceremony they will be holding. No-ankile wants Vusinja to be the master of ceremonies on that occasion. She complains that Vakele has been gone for a long time and that it is possible he has gone to Nomonde.

The essential tensions that underlie the style and tone of No-ankile's remarks introduce the overwhelming tensions portrayed in this drama. No-ankile remarks:

Akakho lowo usaye kufuna iigusha zeli theko langomso. Ekungenzekayo ke nangoku ukuba uye kugqitha ngaphaya kulaa ndlulamthi uNomonde.

Indima 2, Umboniso 4:24

That one has gone to fetch sheep for tomorrow's occasion. It is possible that he passed by that camel Nomonde on his way to the sheep.

Act 2, Scene 4:24

Mkonto turns to two hackneyed words lowo and ndlulamthi into something that symbolizes hatred. He uses this demonstrative lowo (that one) and ndlulamthi to define the alienation and dehumanization of a character by another character.

Vusinja persuades No-ankile to accept Nomonde as her own child. No-ankile responds negatively:

Suka apha! Andizi kuxelelwa nguwe. Uyamazi umntwana wena? Ungandixeleli mna.

Indima 2, Umboniso 4:24

Go away! I am not going to be told by you. Do you know a child? I do not want to be told by you.

Act 2, Scene 4:24

On the other hand, Nomonde also does not speak in a friendly way about Noankile. She despises her. 
Nomonde appeals for help from Zangathini in her conflict with her stepmother. She wants to know if there are any witchdoctors he knows. She is desperate, hence the following rhetorical statements:

Ungandiyeka na ndinyhashwe ngeenyawo? Ungandibukela ndingxiza igazi ngeempumlo nangeendlebe? Ungagcoba na sendithe dudlu phaya ndisisidumbu? Andithi nomama wacholwa enjalo kwaMadangatye?

Indima 3, Umboniso 4:66

Can you allow people to trample on me? Can you just observe while I'm bleeding through the nose and ears? Can you just rejoice even if my corpse is lying there? Do you still remember that even my mother's corpse was picked up at Madanyatye?

Act 3, Scene 4:66

The many rhetorical questions in this speech are reminiscent of the conflict in Nomonde's mind.

Zangathini promises to help Nomonde because he knows a certain witchdoctor at Dyala location. Gogo, Nomonde's helper, advises Nomonde to refrain from revenging herself. Nomonde does not want to listen and this therefore is the source of conflict: The perfect breeding ground for the plot. From this come other points of conflict which lead us to the next episode which is the complication. These conflicts provide many possibilities for the development of plot.

\section{EPISODE 3: COMPLICATION}

Episode three is the complication. It is after No-ankile's birthday party and she is talking to her husband Vakele at home. Vakele is remarking about the party in a friendly manner. No-ankile spoils the conversation by criticizing Nomonde. She is even saying bad things about their neighbours whom she despises. Vakele is not prepared to be enemies with his neighbours.

It is Saturday night at Nomonde's place. Nomonde is chatting to Gogo. Apparently she did attend No-ankile's birthday party. Gogo tells Nomonde that she did not enjoy the party 
because of No-ankile's sarcastic remarks about being the owner of Vakele's home. Nomonde says that No-ankile is jealous of her because she is having fun.

In Scene 5, we are introduced to Sizeka and Vusinja in Sizeka's room. Vusinja tells Sizeka that she is making a mistake because he did not say to her that he will be sending marriage negotiators very soon. He was not proposing marriage at all. Sizeka is devastated because she has already asked her parents to expect guests. Vusinja repeats his words:

Ndiza kuwaphinda awam. Ubozigqogqa iindlebe zakho, mamela ke: Ndithe, Sizi uze usilindele ngom Gqibelo malanga. Nantso ke endiyithethileyo.

Indima 3, Umboniso 4:50

I will repeat myself. You must listen carefully, please listen: I said, Sizi please expect us on Saturday in the afternoon. That is what I said.

Act 3, Scene 4:50

Vusinja tells Sizeka that he is always expressing himseif in the plural form even if he is talking about himself. He is surprised that she is not used to him. Vusinja wants Sizeka to steal money at her work because he wants to buy a car. That is why he made an appointment with her. He wants to use Sizeka for his own needs and he even shares this with his friend Phindile.

Nomonde is ready to fight. She did not get herbs from the witchdoctor. She is not happy with MaNdungwane's visits to her butchery because MaNdungwane is No-ankile's best friend.

Phindile, Nomonde's boyfriend proposes marriage and Nomonde accepts the proposal. The two characters share their good news with Gogo. Nomonde asks Gogo to tell the good news to her father. Gogo is excited.

Marriage negotiators (oonozakuzaku) arrive at Vakele's home in connection with Nomonde's marriage proposal and payment of lobola. 
At night, Vakele tells No-ankile about Nomonde's marriage negotiators but even before that the two are involved in a bitter argument. They quarrel about the way their businesses are managed.

No-ankile feels that she is being bullied by Vakele. She plans to frustrate Vakele and Nomonde by writing a letter to Nomonde's husband-to-be. She is assisted by MaNdungwane in this evil plan. In the letter to Phindile, No-ankile says bad things about Nomonde. She says Nomonde is a witch and she is the driver of the cage which travels to the witches' place at Gwadana. She advises Phindile not to marry Nomonde. The letter is anonymous. Phindile receives the letter and he takes it to Nomonde. Nomonde is positive that the letter is written by No-ankile. The other letter is written to Vakele, telling him to put his wife on a high status in order to be recognized as a mayor. The letter is written as if it comes from the Alice community.

\section{EPISODE 4: CLIMAX}

Episode 4 is the climax. Nomonde, Gogo and Sizeka arrive at Vakele's place with the anonymous letters. It is in the evening. No-ankile does not like the idea of people visiting them late at night, because of the anonymous letters. It is clear that she feels guilty. As they are busy discussing the problem of the anonymous letters, they hear someone crying and immediately thereafter there is a knock at the door. MaNdungwane bursts in the house crying loudly.

Yoo! Yoo! No-ankile! Umntwan'am. Incwadi yakho imbulele umntwana wam. umyeni wam uza kundibulala

Indima 3, Umboniso 2:50

Yoo! Yoo! No-ankile! My child! Your letter has killed my child. My husband is going to kill me.

Act 3, Scene 2:50

No-ankile becomes angry:

Ke! Kutheni? Weza kum? Ndiyintoni emcimbini wenu? Khona wandidibanisa neencwadi zenu! Yihla kum uthi xibilili! 
And so! What? Why do you come to me? What did I have to do with your problems? Why do you associate me with your letters? Get away from me!

Act 3, Scene 2:49

Nomonde tells No-ankile to calm down because she is the first suspect. They question MaNdungwana who admits that she wrote the letters. No-ankile accuses her friends of being responsible for the anonymous letters.

\section{EPISODE 5: DENOUEMENT}

Episode 5 is the denouement. The problem of the anonymous letters is solved. As tension relief, Nomonde tells her father Vakele about the good news that the businesses are flourishing and one of her cousins will be managing one of the shops. Hombakazi praises Nomonde for the wonderful work she has demonstrated in managing her father's businesses. No-ankile says that she is still going to manage her shop herself. Vakele tells No-ankile that he has already written the will about his businesses. He supplies her with a copy. He tells her that the owners of the shops are Hombakazi, Sizeka, Nomonde and himself. She will get her little share from Nomonde. Without even finishing his explanation, No-ankile cries bitterly:

Ndazenza! Ndazenza! Imali yam! Imali yam Tub noNowam imali yevenkile yam yiziseni ngoku! Yeyam loo venkile Tub! Ngumzi wam lo

Indima 3, Umboniso 2:68

I'm to blame! I'm to blame! My money! Tub and Nowam bring my shop money now! Tub that shop is mine! This is my home!

Act 3, Scene 2:68

No-ankile is confused and devastated. It did not dawn to her mind that things would oneday turn out like this.

Nomonde decides to phone the police to take No-ankile to the mental hospital in Fort Beaufort. No-ankile is grabbed by men, because she is now violent and uncontrollable. They bind her with a rope. No-ankile cries out: 
Yeyam! Laa venkile yeyam! Ndim imeyakazi! Ziyathandini ndiyekeni

Indima 3, Umboniso 3:70

It is mine! That shop is mine! I'm the mayoress. You stupids leave me alone!

Act 3, Scene 3:70

\subsubsection{Analysis of the plot structure}

Emgxobhozweni's plot structure can be evaluated according to the following phases:

a) Vakele's heated argument with No-ankile, his wife, of money in their shop. No-ankile reacts in a defensive manner by putting all the money in front of her husband. Noankile accuses Nomonde, Vakele's daughter by the first wife, that she is to blame for the problem of their shop's money. No-ankile is disappointed because she thought that her husband would not listen to his daughter's advice and that she could drive a wedge between them. Vakele on the other hand is not prepared to allow No-ankile to do as she wishes. He prefers No-ankile to leave him instead of disturbing peace in his household. No-ankile is determined to fight on against Vakele and Nomonde who are very close.

b) In their shop, MaNdungwana, No-ankile's best friend, arrives. They gossip about Majola, Vakele's first wife, and her daughter Nomonde. MaNdungwana talks about Majola who was left by her husband Vakele for No-ankile and that she was hated by Majola. She is now rejoicing because her friend No-ankile has taken over and Majola is dead. In actual fact MaNdungwana came to borrow money from No-ankile.

c) In Scene 2, Nomonde is with her cousin, Sizeka at her place and she would not go to work because she has been beaten by her boyfriend. A businessman, Bra Tebro, arrives and he leaves with Nomonde for a business trip. Gogo, Nomonde's helper arrives.

d) In Scene 3, Sizeka does not believe that she will really be getting married. Her mother Hombakazi (who is Vakele's sister) arrives and Sizeka tells her that they must expect marriage negotiators. Nomonde arrives and during that course of their conversation she tells them about her hatred for No-ankile. They all agree that No-ankile is a bad woman. They give her names that fit her character. 
e) In Scene 4, at Vakele's shop, Hombakazi has come to visit her brother in connection with the news of her daughter's marriage. She wants him to accompany her to her husband Mtshilibe to tell him about the good news. Hombakazi narrates her bad dream about the smiling Majola with Nomonde on her back and the sudden appearance of No-ankile in the process with an axe in her hand. This dream symbolizes bad things that are still coming in the drama.

f) Hombakazi advises Vakele to change his will because No-ankile is ripping him off. Vakele promises to share some of the inheritance with Hombakazi because she has also had a helping hand in the ups and downs of her businesses and Hombakazi does not like it that way. In Scene 5, No-ankile asks Vusinga to be an MC at her birthday party. Phindile who is also present during this conversation voices his love for Nomonde and No-ankile gets a chance of belittling Nomonde. At Vakele's place, Vakele informs No-ankile about Nomonde's proposed marriage. No-ankile confronts Vakele for not involving her in the process of marriage negotiations. No-ankile informs MaNdungwana and Nowam about Nomonde's proposed marriage. She says bad things about Nomonde's husband-to-be. Nowam advises that they do something about Nomonde's proposed marriage. They decide to write letters which say bad things about Nomonde in order to spoil her marriage to Phindile. The other letter is purported to be coming from the Alice community, telling Vakele not to ill-treat his wife. Later on, the truth comes out about the writers of these letters.

Dramatic events are well motivated in this drama. The author moves ahead quickly with his story from scene to scene thus maintaining interest and suspense. Symbolism of the play is very notable even the title of the drama itself, a muddy place with stagnate water Emgxobhozweni. The pattern of the dramatic events, the presentation of the personal conflicts of the characters, their hostile interferences as well as confrontations of the symbolic frame of the drama all act upon each other to enhance both the tension of the conflict and the imminence of its resolution. Like certain dramas under study the masterful achievement of this drama is to keep the reader at the center of the turbulence until the end of the drama. It is difficult to separate the first two episodes.

Through the dialogue in this drama, in the very first scene we become aware of the conflict between Vakele, No-ankile, his wife and Vakele's daughter, Nomonde from his first marriage. It is clear that No-ankile is jealous of Nomonde and the fact that she owns one 
of the family's businesses. Her supporters are Nowam and MaNdungwane. No-ankile vows to dig her feet deep and be firm just like a pillar (as her name suggests) to fight very hard for Vakele's businesses. She does not want any stumbling blocks in her way so that is why she hates Nomonde this much. She feels threatened by her close relationship with Vakele, her husband. This is clearly depicted in the following dialogue. No-ankile says:

Sendakufuna ukuba ukuze umntu avane nawe makathethe kakuhle ngesimo sentombi yakho

Indima 2, Umboniso 1:40

I have discovered long ago that if one wants to be on good terms with you then one must say good things about your daughter

Act 2, Scene 1:40

No-ankile's endless belittling of Nomonde continues and that is clearly illustrated in the following speech by No-ankile:

Duks uthetha into yokuba mandiyeke ndibona ukuba kukho impuku ekrekretha le nqanawe yethu

Indima 2, Umboniso 1:45

Duks do you mean that I must keep quiet even though there is a mouse which is biting our boat?

Act 2, Scene 1:45

Vakele loves his daughter Nomonde and is very proud of her. Nothing can blind him from that. He makes that very clear to No-ankile:

Ukuba bubufazi bakho ukundahlukanisa nentombi yam, ngathi ngowukhangela omnye umntu. Ukuba bubufazi bakho ukunyhukula igama lakowethu eludakeni zingela omnye umzi kusakhanya...

Indima 2, Umboniso 1:50

If it's your being a wife to separate me from my daughter, then you might as well look for another husband. If it's your being a wife that allows you to spoil the name of my family in the mud, then go and look for another home while it is still early... 
The conflict between Vakele and No-ankile is clearly motivated and it is a fertile ground for conflict and tension. Vakele is portrayed as a true African man who is not prepared to bow to a wife's demands. He is respected in his community and he is even persuaded to campaign for a post of being a mayor. No-ankile on the other hand is stubborn and fights on. In this drama our attention is taken and developed form one state of interest to another. We are interested in his key character's future when they are changing. We are interested also in various situations because they are changing. No-ankile says:

Kunceda ntoni ukuba ufune ilitha? Negqange lelanga alinakubonisa nto wena.

Ngathi ngowuhlala uyile nto uyiyo...

Indima I, Umboniso I:20

What's the use that you're longing for light? Even the brightest sun cannot show you anything. You better stay as you are.

Act I, Scene 1:20

The above statement by No-ankile is a threat and at once we are anxious to know if it will be carried out. We then speculate on No-ankile's devious plans to show Vakele the "way". This sustains a pattern of interest because an audience looks for life in a play. As in Shakespeare's Macbeth, Mkonto uses the natural forces to depict certain situations in the play. In the first scene, he uses the cloudy climatic conditions to illustrate the quarrel between Vakele and his wife No-ankile.

No-ankile is seen so roundedly and so simultaneously as an evil character by other characters. Her infection spreads outside her own mind and into the minds of other characters like MaNdungwane and Nowam. She sinks into the mud that is referred to in the title of this drama, with these supporters of hers. Her devious plans for inheriting the businesses affect characters like Khwelimfene, Jingxela and Vakele. She is also behind the mayoral post which is wanted by Vakele. She wants this for her own needs.

On the other hand, Nomonde is resistant also to No-ankile's plans. In the further development of the plot the drama offers tensions between, No-ankile and Nomonde. Noankile's portrayal as an evil character is overemphasized. We are even told about the way No-ankile threw out Nomonde's clothes outside Vakele's home together with the photo of Nomonde's mother. 
No-ankile's continued fight against Nomonde is exaggerated. She goes to the extent of saying bad things about her to her husband-to-be. The other letter pretending to be written by the Alice community to Vakele advises Vakele to respect his wife and to give her a higher status if he wants to be a mayor of Alice.

No-ankile's devious plans are represented through the juxtapositions and interpolations of the dramatic movements, through the constant tension created by the dramatic movements all of which reflect the conflicting movements between her and her family.

At the turning point of events, No-ankile and her group are exposed. All their dirty plans are exposed and it is said that No-ankile was the leader of the group. She denies it at first and she loses her mind when told by Vakele about the beneficiaries in his will. Though she behaves in a mad manner, she still claims that the shop is hers as well as the mayoral position.

Clearly the author has exaggerated the portrayal of No-ankile because he wants to put across his message of a woman who is greedy and devious. The episodes are peppered with quotations from characters dialogues that lend a dramatic coherence to the entire work.

In each episode the author identifies the key actors and the location of the action, and then the characters take the floor to determine the nature of the drama. In the first scene Noankile challenges Vakele, which effectively initiates the struggle between the two. The following scenes describe the events that transpired a few years earlier, and serves therefore to explain one cause of the quarrel between Vakele and No-ankile. The quarrel hinges upon No-ankile's demand for Nomonde's isolation and Vakele's refusal. In the last two scenes Nomonde uses her resourcefulness to expose No-ankile's devious plans.

\subsection{2 lintombi zinecebo (R. Mcimeli, 1992)}

\subsubsection{Episodes}

\section{EPISODE 1: EXPOSITION}

In episode one, which is the exposition, there is the laying out, the putting forth of the materials in the work: the main characters, Mvuzo and Nomhle, their backgrounds, their 
characteristics, basic assumptions about their life, goals, limitations and potentials. The drama takes place in the rural area. It begins with Mvuzo sitting in the lounge, in deep thought. Mvuzo is in a bad mood. The setting of this drama reaches the level of symbolism in which the playwright employs a detail of setting to stand for a condition of life. The terrible condition of Mvuzo's home is such a symbol. This is a very poor home. It is said that Mvuzo is sitting at his home at sunset. The presence of this natural condition, that is the sunset in the episode of this drama provides the substance for the development of the playwright's meaning:

(Kuxa lijikayo ilanga. UMvuzo utshaya izoli ebonakala ecinga nzulu. Ebusweni uh/wile. Igumbi eli akulo lizaliswe ziisofa ezindala nezikrazukileyo. ... kukho bukhabhathana bugqolileyo buzaliswe ziiglasi, komityi, iipleyiti neeketile ezimdaka zimbi zaphukile)

Indima I, Umboniso 1:1

It is sunset, Mvuzo is smoking "zol" and he is deep in thought. He is in a bad mood. The room in which he is, is full of dirty and torn sofas. ... there is an old cupboard which is full of dirty glasses, cups, plates and kettles some of which are dirty, some are broken.

Act I, Scene 1:1

The story opens with the metaphor of the description of the contents of the house reflecting the bad state of affairs at Mvuzo's home. By making setting to intersect with characters, the playwright underscores the importance of place, circumstance and time on human growth and change. The impoverished, dreary lounge of Mvuzo's home enables us to understand at least partly why Mvuzo is in such a desperate situation. Mvuzo voices out his frustration:

Le meko sikuyo nodade wethu andinakho ukumelana nayo. Iyandisinda apha engqondweni. Kufuneka ndivele necebo. Liyasibhuqa iphango kwaye kulo mzi ngathi kusenxuweni ngoku kukho abantu. Ukongeza kuloo nto kukho le ntsumantsumane kaNomhle. Kufuneka isonjululwe. Ewe ingathi yile meko kaNomhle kanye enokusikhupha kule meko sikuyo ukuba nje unokuthi azimisele ukusebenzisana nam. 
I cannot tolerate the situation in which we are with my sister. It is getting on my nerves. I must come up with a plan. We are dying of starvation and this home looks like a deserted one even though there are people in it. In addition to that situation there is Nomhle's predicament. It must be solved. Yes, seemingly it is Nomhle's predicament that can rescue us but only if she will cooperate with me.

Act I, Scene I:1

The first seed of conflict is planted in Mvuzo's monologue. Mvuzo decides to enrich himself with Nomhle's pregnancy. Nomhle, Mvuzo's sister, is pregnant and she is not sure who the father of the unborn child is. She has two boyfriends, Madoda and Vukile. Mvuzo is the head of the family because their parents passed away. Mvuzo calls Nomhle who is in the kitchen, angrily. Nomhle is a beautiful girl but she looks sad. Nomhle goes to Mvuzo who remarks about her sad physical appearance. Mvuzo thinks that Nomhle could still be mourning the death of her mother who passed away during the previous year. Apparently their father passed away on the previous day. Nomhle explains that she is still devastated and mourning because their parents left them in a serious predicament. Moreover, Nomhle elaborates, their parents died without solving her problem. Mvuzo and Nomhle were dependent on their father's pension money. Nomhle is sad also because her father died while he was still angry with her because of the pregnancy. She says that if she had money then she would ask her brother to ask for forgiveness to her father on her behalf. This is usually performed by the man performing certain rituals like slaughtering a beast or sheep.

Mvuzo explains to Nomhle that unfortunately they are poor at home and they have absolutely nothing. They do not have cattle, goats, sheep and their field is not ploughed. The two characters are still dependent on their parents funeral donations. What is killing them most is the fact that people in the location gossip about their sad state of affairs. Mvuzo and Nomhle are still paying their parents' debts which they cannot afford anymore. Nomhle regrets her pregnancy and she cries. She is consoled and comforted by Mvuzo who suggests that they must think about a plan that can help them solve their problems. Mvuzo feels that even if they are in trouble, he has visions about their home being rich in future. He says that is possible only if Nomhle is willing to co-operate with him. Mvuzo asks Nomhle if she still does not know who her baby's father is. Nomhle is not prepared to guess because that can put her child in great danger on account of rituals to be performed 
for the child. Mvuzo assures Nomhle that his plan is a good one because through his plan they will never have problems anymore. In trying to force Nomhle to accept his plan, he reminds her about their parent's teachings that a promise is a promise and if one makes a vow then that vow is supposed to be honoured. Mvuzo explains that their parents used to tell them that one must be prepared to die rather than break a vow. Nomhle agrees with Mvuzo. One notes cultural assumptions which these characters make about themselves. For instance, Nomhle tells Mvuzo that the home belongs to him now that their parents are dead and as such he has a right to force anyone to leave the home at any moment if he likes:

Ngoku umzi ngowakho. Unalo ilungelo lokugxotha nabani na kuwo xa uthanda.

Indima I, Umboniso I:4

Now the home is yours. You do have a right to evict anyone if you like.

Act I, Scene 1:4

The cultural assumptions cited in the above dialogue do affect Nomhle and Mvuzo's judgements and actions.

Mvuzo takes time to tell Nomhle what his plans are concerning the solution of their problems. Nomhle persuades him to tell her what the solution of their problems is. Mvuzo demands food before telling Nomhle about the solution. Mvuzo's monologue shows that he knows that his plans are cruel. He wants to use Nomhle to enrich himself. Mvuzo says:

Andinatyala. UYehova uya kundixolela.. Nam andincedi ndizama ukulungisa imicimbi yekhaya lam khona ukuze mna, udade wethu lo nomtshana wam lo uzayo siphile njengabanye abantu. Ithi ukuze iphile indoda imbe kwenye eqolo, batsho abadala.

Indima I, Umboniso 2:4

I am not guilty. God will forgive me. I cannot help it, I am trying to make my home affairs right so that myself, my sister and my coming nephew live like other people. There is an old saying that in order for a man to survive then he must suck on the others. 
At this point, Nomvuyo and Lizeka who seem to be friends appear in the scene too. They chat about girls who are fortunate in the sense that they stop schooling and get married. They chat also about wedding ceremonies which they have been attending hence they could not see each other for a long time. They even sing the wedding songs thus showing that they are really having a good time. In their conversation they talk about Nomhle who has two boyfriends. We learn form the conversation of the two girls that at first Nomhle was in love with Madoda and then she discovered that Madoda was in love with another woman as well. Because Madoda promised Nomhle that he will never fall in love with another woman then Nomhle could not accept Madoda's unfaithfulness. She rejected him and immediately thereafter fell in love with Vukile. She got pregnant in the process of these two love relationships.

Nomhle suspects that Vukile is also in love with another woman by the name of Nozizwe. She decided to reject Vukile. That is how Nomhle's problems start. She rejects her two boyfriends not knowing that she is pregnant. Moreover, she does not know who the father of her baby is.

Nomvuyo and Lizeka envy Nomhle for having two boyfriends. That they are still not married is frustrating them because they are always told by their mothers that the home of a woman is in marriage. They say that it does not matter how well educated one is. The two girls are really frustrated by not getting married. They wipe tears from their eyes.

Scene III opens with Mvuzo and Nomhle drinking coffee in the livingroom. Nomhle reminds Mvuzo about something, which Mvuzo promised to tell Nomhle. Mvuzo reminds Nomhle that she is pregnant and no one has paid yet for her pregnancy. He says that the two men in Nomhle's life have not yet paid for the damages. Mvuzo plans to force the two men to pay money for the damages and if Nomhle does not agree with him then she must pack and go as Mvuzo is now the head of the family. Mvuzo wants the two men to pay because Nomhle does not know who the father of the baby is. Nomhle is horrified by this suggestion. She says:

Yhu! Yhu! Yhu! Yhu! Uthi kutheni bhuti? Yakha yakho into yokuba intombi enye ihlawulwe ngabafana ababini? 
Yhu! Yhu! Yhu! Yhu! What do you say, my brother? Does it happen that one girl should be paid damages for pregnancy by two men?

Act I, Scene 3:10

Nomhle does not agree with her brother. She feels that it is not the way to solve this problem. She still thinks about her father's words that if Nomhle chooses the wrong man as the father of her baby then she will be bringing misfortunes to her home because she will be forced to use the father's customs for the child. Mvuzo tells Nomhle that he is going to force her to do as he wishes. Nomhle is upset and cries bitterly. Mvuzo says that on the following day they must go to Vukile's place for the payment of pregnancy damages and then thereafter to Madoda's place.

\section{EPISODE 2: MOTORIC MOMENT}

Episode 2, which is the motoric moment, opens with Mvuzo and Nomhle on their way to Qwiliqwili, Vukile's home. On the way, Mvuzo tells Nomile how to respond to questions being asked by Vukile's family members. At Vukile's place, Mvuzo and Nomhle meet Dumephi and they discuss Nomhle's pregnancy. Mvuzo and Dumephi exchange words. There is no co-operation at all. Dumephi wants to beat Mvuzo with a stick because he feels that they have come to disturb him at his home. As he is still preparing to beat Mvuzo, Vukile appears all of a sudden. He recognizes Nomhle and is then filled with joy for meeting her after such a long time. Vukile goes straight to Nomhle and he hugs her. He says:

Owu Nomhle sithandwa sam kunini ndikukhumbula? Kunini ndiyilindele le mini? Kaloku neeleta zam akuziphenduli. Ndagqibela ukufumana ileta yakho ngalaa leta wawundixelela kuyo ukuba unto.

Indima I, Umboniso 3:15

O! Nomhle my love, I've been missing you. I've long been waiting for this day. You do not even answer my letters. I last received a letter from you when you wrote me informing me that you are pregnant. 
Vukile kisses Nomhle and Mvuzo and Dumephi are looking at them. Vukile looks at Dumephi and Mvuzo. He is surprised by their sad look. Dumephi tells his son Vukile that he is upset because the child is not his. Vukile tells his father that the child is his. He is not prepared to listen to his father's explanation. Vukile informs Mvuzo that he is aware that he is supposed to pay the damages. He wants to know the amount he is supposed to pay. Mvuzo quickly tells Vukile that he is supposed to pay five cattle and that each costs R300-00. Dumephi persuades Vukile to listen to his advice because this problem is not his alone. It involves everybody at his home. Mvuzo is excited. He even demands another cow in addition to the five cattle for damages. Dumephi is devastated because he realizes that Mvuzo has come to exploit them.

Nomhle tells Vukile not to come and visit her without an appointment. She explains that she does have reasons for that. Vukile promises Nomhle that he is going to marry her.

In scene V, Mvuzo tells Nomhle that they must quickly finish having their meal as they will be going to Madoda's place for another payment. Nomhle is surprised. She tells him that a girl cannot be taken to two homes for the payment of pregnancy. Mvuzo responds by saying that it does happen if a girl has two men in her life. Nomhle tells her brother that she is not prepared to go to Madoda's place. Mvuzo forces her to go with him. Nomhle cries sadly:

Owu yini bhuti mntwan'asekhaya undenzani? Khona ukuba ndone kangakanani ungasele undenza le nto?

Indima I, Umboniso 4:18

O no, my brother. What are you doing to me? How can you do such a thing to me even if I have done something wrong to you?

Act I, Scene 4:18

Mvuzo tells Nomhle that they need money because their parents left them with debts. Moreover, Mvuzo says that he wants to punish men who have love relationships with girls and do not respect African customs. Mvuzo reminds Nomhle about her vows and promises that she will do everything that her brother wants her to do. Nomhle cries: 
Ndithe uxolo bhuti kaloku yhini Gcwanini! Ndisatshele kwisifungo nesithembiso sam sokuba ndiya kwenza konke othi mandikwenze

Indima I, Umboniso 4:18

I said sorry brother, O Gcwanini! I am still bound by my vows and promises that I will do everything that you want me to do.

Act I, Scene 4:18

In Scene VI, Mvuzo and Nomhle arrive at Madoda's place. Nomhle is still covering herself with a blanket as she did at Vukile's place. Mvuzo is in a bad mood. Sityebi, Madoda's father asks Nomhle questions about her pregnancy. Later on, Sityebi tells Mvuzo and Nomhle that Madoda has long been talking about Nomhle who will be brought to his home one-day because Madoda is the father of the baby. As they were busy discussing this problem, Madoda enters. He is excited to see Nomhle. He says:

(Ejonge kuNomhle, ebonakala esemincilini) Nomhle, Nguwe lo sithandwa? (ejonga kuyise) Ndiyayazi tata le nto Lo mntwana ngulo ndandinixelele ngaye nomama, Dlamini.

Indima I, Umboniso 6:20

(Looking at Nomhle, joyfully). Nomhle! It is you, love! (Looking at his father) I know this thing father. This is the child I told you and mother about, Dlamini.

Act I, Scene 6:20

In the process of the discussions, Madoda asks for permission to have a word with Nomhle. In their secret meeting, Madoda proposes to Nomhle. He wants to know if Nomhle is sure that the child really is his. Nomhle cries saying that she is sure that the child is his.

Mvuzo tells Madoda's family to pay five cattle for damages. Each cow is R500-00. He says that this money is meant to raise the child because the cost of living is high.

Act 2, Scene I opens with Nomhle and Mvuzo sitting at home. It is towards the end of the month and Madoda's family has finished paying for Nomhle's damages on that day. 
Nomhle gave a letter addressed to Madoda requesting him not to visit her unless told by her. She claimed to have reasons for that.

In this scene, Nomhle asks Mvuzo what the position would be because both Madoda and Vukile agree that Nomhle's child is theirs. Nomhle explains that no girl is paid damages by two people for one pregnancy. Mvuzo is angry and reminds Nomhle that Vukile has not yet paid and yet he did promise that he would pay. Nomhle wants them to ignore Vukile and the payment and talk about Madoda's issue only. She feels very uncomfortable about this situation. As they are busy discussing the problem there is a knock at the door. Two men sent by Vukile's family enter. Mvuzo asks them questions and thereafter they pay a sum of two thousand rands. Mvuzo is satisfied with the payment. He smiles as he is busy counting it. The two men apologize for not bringing cattle. Nomhle is devastated and she leaves Mvuzo and the two men crying. Mvuzo puts the money in his pocket. The two men remark that Nomhle is fit to be a wife because she shows signs of being a hard worker.

The two men do not understand why Mvuzo is handling the custom of this nature on his own together with his sister. They say that there is not even a witness and they find that to be very strange. They ask if people are called when marriage negotiators come to pay lobola or not. The two men leave and Nomhle is crying uncontrollably. She cannot even talk because she hates what her brother is doing but unfortunately she is afraid of him. She bravely reprimands her brother:

Zizimanga zantoni ezi undenzela zona?

Indima 2, Umboniso I

What horrible things are you doing to me?

Act 2, Scene 1

Nomhle tells her brother that he should not have taken Vukile's money because Madoda has already paid. She reminds Mvuzo that both Vukile and Madoda's homes are interested in taking her as their daughter-in-law. Nomhle tells Mvuzo that she does not know how to solve the problem of the two men in her life:

Ndiza kwala njani kuVukile nakuMadoda? Ndiza kuthi siyintoni isizathu sokwala kwam ekubeni bendifungile kubo bobabini ndathi ndiyabathanda? Ndiza kuthini ngoku bhuti ndize ndibathini bona? 
How am I going to refuse Vukile and Madoda? What will I say the reason is for my refusal and yet I did admit to both of them that I love them? What am I going to do, brother, and what am I going to do with them?

Act 2, Scene 1

Mvuzo responds to Nomhle's frustration in a very cruel manner. He suggests that if the two men want to see Nomhle then she must simply refuse to see them. A violent argument ensures between the two characters:

Mvuzo: Bazimele qha ungavumi ukudibana nabo

Mvuzo: Just run away from them and refuse to meet them

Nomhle: Kude kube nini?

Nomhle: Until when?

Mvuzo: Kude kube nini na? Ude ubonwe lelinye isoka likulobole likutshate

Mvuzo: Until when? Until you meet another man who will pay lobola and then marry you.

Nomhle: (Sele ephelelwe ngamandla yintlungu nakukulila)

Owu buthi! Bhuti! Undenzani mntwana katata?

Nomhle: (Devastated and powerless from pain and crying)

$\mathrm{O}$ ! brother, brother! What are you doing to me, child of my father?

Mvuzo: $\quad$ (Ephakama enomsindo) Ndidiniwe mna yiyo yonke le nto yakho. Zibonele into oma uyenze ngamasoka akho. Nokuba uwalile nokuba utshatele kuwo omabini, ngexesha elinye, ikuwe loo nto, Mna ngoku ndiya kufaka le mali ebhankini eGcuwa (Aphume emshiya uNomhle equbudile egixa)

Mvuzo: (Standing up angrily) I am tired of all your problems. See what You can do with your men. Even if you reject then marry them Both, that depends on you. I am now going to deposit this Money at the bank in Butterworth. (He leaves Nomhle bursting In tears) Indima 2, Umboniso 1:25 
Nomhle is in a very serious dilemma, because of her brother's greed. She does not know what to do. Her predicament transpires from what she says:

(Ethetha yedwa) Kowu, Bawo wam kazi ukuba yinto endiza kuyithini na le! Abantwana babantu bahlawule bobabini kodwa ngokuqinisekileyo mnye umenzi wento. UVukele undibhalele esithi xa singekazukubonana mandibe ndivuma ukuba oonozakuzaku baqandule baze bazokundicela. Ndisamnqandile nakuleyo into okwangoku. Ndithe uya kubuya eve kwangam. Ndiza kubathini na maGcwanini aba bantu babini? Ndiya kubabaleka kude kube nini? (Esathetha njalo kuza umntwana kuye)

Indima 2, Umboniso 1:26

(Talking to herself) O my Lord, how am I going to solve this problem? The two men have both paid and yet I am sure only one is responsible for this. Vukile has written me a letter saying that although I have not met with him yet I must at least allow his family's negotiators to begin the marriage negotiation procedure. I have not yet allowed him to do even that. I said he will hear from me soon. What am I going to do, Gcwaninis, about these two men? I will avoid and run away from them till when?

Act 2, Scene 1:26

Whilst Nomhle is busy talking to herself a child arrives. Madoda sends the child to Nomhle. Nomhle tries to tell Madoda that the child may not be his. Madoda does not want to listen. He does not understand what Nomhle is talking about. He tells Nomhle that he is missing her and that he wants to discuss a certain issue with her. Nomhle panics because her brother went to town and he will come back hungry. She does not want to be delayed preparing food for him. Madoda informs Nomhle that his family is looking forward to seeing her. He proposes marriage to Nomhle who tearfully responds by saying that she does love him but first she would like to share something with him. She tries to tell Madoda that she is worried the child could be Vukile's.

Ndinexhala ngoVukile kuba lo mntwana ...lo mntwana ...le ndlela aze ngayo ...lo mntwana ...lo mntwana ... le ndlela aze ngayo ... lo mntwana ...lo mntwana ... 
I am worried about Vukile because this child ... this child ... the way he has come ... this child ... this child...

Act 2, Scene 2:29

Madoda thinks that Nomhle is talking about his uncle Vukile. He is surprised that Nomhle knows his family. It is clear that he does not understand what Nomhle is talking about in her excited state. Nomhle explains that she is confused because of the two men Madoda is the best. Madoda tells her that he does not like what she says because her brother is the man of the house now that their father is dead and should not need to be compared with Madoda. He still does not understand what Nomhle is trying to say. He thinks that she wants attention. He wraps up their conversation by telling her that his family will send marriage negotiators very soon.

\section{EPISODE 3: COMPLICATION}

Episode three is the complication. It begins with the description of the change in Mvuzo and Nomhle's lives. They are now rich. Nomhle has given birth to a baby boy. They have cattle, sheep, goats, pigs and chickens. Their fields are ploughed. Mvuzo and Nomhle wear beautiful and expensive clothes.

Mvuzo asks if Nomhle has decided on the man she will be marrying of the two. He says he is interested in marriage and lobola. He tells Nomhle that the child looks like Vukile and so she must marry him. Nomhle is unhappy because she loves Madoda. As they are busy talking, there is a knock at the door and it is certain members of the family of Vukile. They have come to visit the child and see if it is theirs. Having seen the child, they realize that he does not look like Vukile or any of their forefathers. Dumephi says Nomhle's baby is not Vukile's child at all. He says:

Lo mntwana akangowakwaMajola. Ngowomnye nje umgewu ongaziwayo

Indima I, Umboniso 4:12

This child does not belong to the Majola clan. It belongs to some other unknown person. 
As he finishes saying that, a snake enters and moves towards Nomhle. It is seen by one person only because all the other people are looking at Dumephi who is still busy arguing that the child is not of the Majola clan. The woman who sees the snake draws the attention of the other people in the house to the snake. They all bow their heads thus showing respect to the Majola snake. Dumephi immediately apologizes to Majola clan for denying that the child is theirs because they believe that the arrival of the snake is a sign indicating that the baby is theirs. He believes that their ancestors show them with the sudden appearance of the snake that they are making a mistake by denying that the child is theirs. Mvuzo and Nomhle are taken aback because they did not even see the snake. Their guests leave.

In Scene IV, Dumephi and the other people with whom he went to Nomhle's home give a report. Dumephi explains that at first he did not believe that is Vukile's until the Majola clan proved to them by the appearance of the snake. Some people who also visited Nomhle's home do not agree that the snake is the one of the Majola clan. They say it is another type of snake known as inkwakhwa. Vukile says that whether the snake was a Majola snake or not, the child is his and he is prepared to marry Nomhle. He has decided and he does not want any interference. Vukile says:

Nokuba nibone ntoni na okanye nicinga ntoni na uNomhle ngowam. Laa mntwana kaNomhle ngowam.

Indima 2, Umboniso 4:34

I do not care what you have seen or what you think, Nomhle's child is mine. Nomhle's child is mine.

Act 2, Scene 4:34

Dumephi tells people in the meeting that there is nothing they can do because his son has decided and there is no turning back:

MaNgwanya akusekho nto sisenokuba sayithetha ngoku Xa unyana egqibe ngolo hlobo kugqityiwe 
MaNgwanya there is nothing we can say now. If my son has decided that way, then it is finished.

In the next scene, scene $V$, Mvuzo is a happy man because things are going very well for him. As he is busy cleaning his shoes, Nomhle quickly enters. It is as if someone is chasing her. Nomhle tells Mvuzo that some members of Madoda's family have come to see the child. Mvuzo is very calm and seems not to understand why Nomhle is panicking. Nomhle is concerned because people from Vukile's home have already claimed the child and moreover Mvuzo did agree that the child looks like Vukile.

The visitors are then called by Mvuzo to go to another house to see the child. They remark that the child looks exactly like Madoda and they are happy. Nomhle is worried and she is choking tears back because the whole situation is now complicated. Mvuzo is also concerned and keeps on looking at Nomhle who is extremely upset. Nozolile, one of the women who have come to visit Nomhle's child tells her that they are looking forward to seeing her being their daughter-in-law. Mvuzo is furious now and wants these women to leave. He says angrily:

Bomama lo mntwana ngumntwana wentombi. Umntwana wentombi ke ngowakulonina. Musani ukuthetha ngathi nithetha nomolokazana wenu xa nithetha noNomhle.

Indima 2, Umboniso 5:40

Mothers, this child is the child of an unmarried woman. A child of an unmarried woman belongs to his mother's home. Do not talk as if you are talking with your daughter-in-law when talking to Nomhle.

Act 2, Scene 5:40

The women leave Mvuzo's home and Nomhle who all along is choking back tears, cries openly. 


\section{EPISODE 4: CLIMAX}

Episode 4 is the climax. Vukile and Madoda's families both claim that the child is theirs. Mvuzo and Nomhle find themselves in a tight corner. Both families talk about a marriage. Nomhle has long been delaying meeting them. She cannot continue like that anymore. She wants her brother Mvuzo to make a plan. Mvuzo has no solution. He explains that all along he thought the child was Vukile's, but now he agrees with Madoda's family members that the child is Madoda's. Mvuzo suggests that Nomhle must choose the one she loves and marry him. Mvuzo says:

Xa kunje landela intliziyo yakho uye kule ndawo ikukhokelela kuyo

Indima 3, Umboniso l:38

If things are like that, then follow your heart and go to where it leads you.

Act 3, Scene 1:38

Nomhle accuses Mvuzo of not supporting her because he is now rich from her mistakes. Mvuzo becomes furious and tells Nomhle to leave his home because she does not want to co-operate.

Lizeka and Nomvuyo meet. It is clear that the two are friends. Lizeka tells Nomvuyo about Nomhle's two men in her life as well as her own affair with Mvuzo, Nomhle's brother. Nomvuyo looks sad because she has no man in her life and as such she is always lonely. Nomvuyo envies Nomhle and Lizeka for having men in their lives. Nomvuyo believes that her friends who are jealous of her bewitch her. Lizeka becomes furious and demands to end their friendship. She wants to beat Nomvuyo and Nomvuyo apologizes. Lizeka does not want to listen and she leaves her.

In Scene III, which is the climax of the drama, Mvuzo suggests to Nomhle that they must make a plan in order to solve Nomhle's problem because he is now rich. The problem must be solved so that they can enjoy their wealth without any fears. Mvuzo says:

Ngoku ndizifumene zonke izinto endandizifuna. Kulo mzi kuyinkuku, kuyihagu, kuyinkomo, kuyigusha kuyibhokhwe nje, ndide ndanalo nehashe lembala. Onke amatyala awaye enziwe ngabazali bethu ahlawulwe. 
Ndihlonitshiwe elalini kwaye nomzi wasekhaya uhlonitshiwe, Ngoku into eseleyo kukusonjululwa kwale ngxaki yakho ukuze nawe ude wonwabe ubuxhamle ubutyebi balo mzi ungenaxhala lanto.

Indima 3, Umboniso 3:46

I got everything I wanted. In this home there are pigs, cattle, sheep, goats, and I even have a horse. All the debts left by our parents are paid up. I am respected in this location and our home is respected too. What is left now is the solution of the problem so that you can be happy and enjoy the wealth of this home without any fears.

Act 3, Scene 3:46

Mvuzo suggests that Nomhle should write letters to Madoda and Vukile informing them that she is now married. Nomhle must tell them that the child would be left with her brother Mvuzo. Mvuzo thinks that by so doing then the two men will give up. Nomhle does not share her brother's advice. They exchange bitter words and Mvuzo ends up by saying that Nomhle must do as she wishes. He says he does not care whether for two weeks she marries Madoda and immediately thereafter marries Vukile for another two weeks. Nomhle is devastated and she wishes that she were dead instead of suffering like this. Nomhle cries:

Owu Bawo wam akwaba bekunokusuka nje kuse ndifile. (Elila kalusizi) Ewe inye indlela yokuphuma kule nto kukuba ndife.

Indima 3, Umboniso 3:47

O my Lord, I wish by tomorrow I could be dead (crying sadly) Yes, there is only one way out of this and this is death.

Act 3, Scene 3:47

Mvuzo wants to know if Nomhle wants to commit suicide and Nomhle tells him that had it not been for her father who told her that committing suicide is a sin, then she would have killed herself long ago. She tells her brother that he is hurting her and the pain is severe; her heart is broken. Nomhle says: 
Owu bhuti ezi zinto uzithethayo zindenzakalisa ngakumbi. Ziwukrazula ngekrele umphefumlo wam. Ziyenza mandundu imeko endikuyo

Indima 3, Umboniso 3:47

O brother, the things you are saying to me are hurting me more. They tear my soul with a spear. They are only making things worse.

Act 3, Scene 3:47

Mvuzo is touched by Nomhle's words and he comforts her by suggesting they talk about something else. Mvuzo tells Nomhle that he has an appointment with a certain girl. He explains to Nomhle that he is old and as such he wants to get married. Nomhle reminds Mvuzo about his ex-girlfriend, Nongephi, who disappointed him. Mvuzo's girlfriend is Lizeka and apparently Nomhle knows her because they were in the same class in school. She praises her and suggests that Lizeka can make a good wife. She has true love. Mvuzo is excited, because he loves Lizeka. He says he will be going to fetch Lizeka and then leave them alone so that they can chat. Nomhle thinks that by chatting with someone else she would ease the burden on her shoulders. Mvuzo persuades Nomhle not to keep on crying because her problems will be solved very soon. Nomhle and Lizeka finally meet and thereafter they visit each other regularly.

Nomvuyo and Lizeka have an appointment on a certain day. Nomvuyo asks for forgiveness because she accused Lizeka of bewitching her so that she does not get a man. Nomvuyo admits that she was channeling her frustration of not getting a man at the wrong direction by accusing her of witchcraft. She wants Lizeka to help her get the love of her life. Lizeka forgives Nomvuyo and informs her that she does have a plan for her so that she can get a boyfriend. First of all, Lizeka tells Nomvuyo about Nomhle's problem of having two men in her life who have both paid money for her pregnancy. Lizeka plans to kill two birds with one stone because by solving Nomhle's problem, at the same time, one of the two men in Nomhle's life will be Nomvuyo's if she assists her with the plan. Lizeka shows Nomvuyo Madoda and Vukile's photos. She says she must choose the one she loves. Lizeka says the two men are both rich and they have true love.

Lizeka explains that Nomhle is rich with men and they must take one of her riches in such a way that Nomhle is not to blame for breaking vows and promises. It must be one of the two men who is to blame. Apparently Nomhle did tell Lizeka about the man she loves 
most, but the problem is that she does not know who the father of her child is. Lizeka feels that the time of solving Nomhle and Nomvuyo's problems has come. Lizeka writes letters of appointment to Madoda and Vukile pretending to be Nomhle. She suggests in the letters that they meet at ten in the morning on the following Saturday at Noqaza forest. Both men receive letters.

In Act 4, Scene I, Lizeka and Nomvuyo go and hide at the Noqaza forest. They lie on their stomachs and whisper to each other because they want to observe everything and then act. Madoda arrives at the scene and immediately thereafter Vukile shows up. They do not bother themselves about each other. Later on they become interested in each other and they chat. Vukile tells Madoda that he has an appointment with his girlfriend and he does not want to tell him who the name of his girlfriend is. He praises his girlfriend saying that she is beautiful. He does not want to be disturbed in his relationship especially because women are unfaithful. They are both panicking because their girlfriends do not arrive.

Lizeka and Nomvuyo are admiring the two men, but they are still lying on their stomachs so that they cannot be seen. Nomvuyo loves Vukile. Madoda hears their voices and wishes that he could send people to call their girlfriends. Two girls who are going to fetch water from the river appear at a distance. They are Zuzeka and Nomfundo. Vukile suggests that had it not been for the lack of girls at the place in which they are then they would pretend to be talking to those girls to make their girlfriends jealous.

Lizeka asks Zuzeka and Nomfundo to walk next to Madoda and Vukile and if they call them they must go to them. Meantime Lizeka goes to Nomhle and tells her that Madoda is busy hugging and kissing another woman. Nomhle becomes angry and decides to go immediately to the place where Madoda is said to be. Lizeka leaves immediately thereafter.

Madoda and Vukile call Zuzeka and Nomfundo. They all sit down and chat. After a while they hear footsteps and Nomhle appears all of a sudden next to them. Zuzeka and Nomfundo take their buckets and leave immediately laughing at the top of their voices. Nomhle becomes angry and shouts at Madoda saying: 
Madoda, sithandwa sam, undenzani? Yhini tata kaMziwandile? Kanti unje ukungathembeki?

Indima 4, Umboniso II:59

Madoda, my love, what are you doing to me? O Mziwandile's father? Are you so unfaithful?

Act 4, Scene II:59

Vukile appears and goes straight to Nomhle smiling with his arms wide open saying:

Nomhle! Nomhle! Luyolo Iwentliziyo yam. Mthunzi wam wokuphumla! Bendisazi ukuba uyeza sithandwa sam senyaniso

Indima 4, Umboniso II:59

Nomhle! Nomhle! Nomhle! Joy of my heart! Shadow of my rest! I knew that you were coming my true love.

Act 4, Scene II:59

Both men hug and kiss Nomhle. Nomhle is shocked. She does not understand what is happening. She cannot express herself properly. She says:

Nenzani na nina ... Madoda sith... Vukile sith ... nenzani ... na ... ni ... na?

Indima 4, Umboniso II:59

What are you doing... Madoda lov... Vukile lov... what are you doing...?

Act 4, Scene II:59

Madoda is shocked. He wants to know what is happening. Nomhle is ashamed of herself. Madoda confronts Vukile because he claims that the girlfriend and the child are his. Vukile confronts Madoda as well:

Madoda: Hi Vukile yintoni entombini yam nasemntwaneni wam?

Madoda: Hey Vukile, what do you want from my girl and child? 
Vukile: Kanti wena Madoda uyintoni elusatsheni Iwam?

Vukile: $\quad$ And you Madoda what do you want from my family?

Indima 4, Umboniso 2:60

Act 4. Sceme 2:60

The two men, Madoda and Vukile fight. Lizeka and Nomvuyo are still watching this showdown from a distance. Nomvuyo is worried because Madoda strangles Vukile and she has feelings for him. She goes straight to Madoda and bites him. Madoda thinks that it is Nomhle who is biting him, thus helping her lover. Madoda cries:

Yhoo! Yhoo! Nqandani! Uyandiluma! Uncedisa isithandwa sakhe! Yhoo!

Indima 4, Umboniso 2:59

Yhoo! Yhoo! Help! She is biting me! She is helping her lover! O Nomhle my love, Yhoo!

Act 4, Scene 2:59

Nomhle wants to know how many people are there. She tries desperately to stop the violent fight. She wants to explain everything to them. Nomhle's baby cries because of the violent confrontation. Mvuzo arrives and prepares himself for a fight. He wants to know who is fighting who, because the people now just beat anyone. The fight stops and the two men wipe blood from their mouths. Vukile and Madoda are afraid of Mvuzo. They want to run away. Mvuzo confronts Nomhle for being in such a violent scene. Nomhle apologizes but wants to explain that she is the cause of the problem. Furthermore, she says, Mvuzo is equally guilty.

Lizeka and Nomvuyo appear and they stand next to Mvuzo. Mvuzo is shocked because he did not know that Lizeka was around. He asks her if she is a witch or not. Lizeka tells Mvuzo boldly that he is the principal witch and his sister is also a witch and Mvuzo is the cause of the witchaft. She says that Mvuzo is the cause of the problem that led to the violent confrontation. Lizeka wants to be given a chance to solve the problem. Mvuzo wants to solve it himself but he would like to discuss it at his home and not in the forest. He instructs Nomhle to go home and be followed by Madoda. Lizeka feels that by the time they finish discussing this issue they would be starving. She then asks Nomvuyo and 
Vukile to go and buy food at the shop. Mvuzo does not agree but Lizeka persuades him to support her. Nomvuyo and Vukile go to the shop arm in arm.

\section{EPISODE 5: DENOUEMENT}

In the fifth episode, which is the denouement, the actions of characters change and the conflict approaches an end. This episode's function is to restore order, to unify and complete the course of action. It provides an ending that seems necessary and probable as the result of the earlier development. The play's denouement shows fairly good dramatic integrity.

In this episode we see Nomvuyo going to the shop with Vukile. Vukile explains to Nomvuyo that Madoda wants to take away his girlfriend with whom he has a baby. Furthermore he wants to marry his girlfriend. Nomvuyo tries to convince Vukile that Nomhle is unfaithful. Vukile persuades Nomvuyo to tell him everything that she knows about Nomhle. He promises to do anything for her in return. Nomvuyo tells Vukile the whole story of their love triangle and Vukile is shocked. Nomvuyo seduces Vukile and they kiss. It is clear that they are now in love. They delay in the shop and at Mvuzo's place, Nomhle, Mvuzo and Lizeka are anxiously waiting for them. Nomhle is surprised that Vukile went to the shop with Nomvuyo. She asks:

UVukile uhambe noNomvuyo baya evenkileni? Bobabini? Bayokwenzani evenkileni? Ngubani obathume evenkileni, bobabini?

Indima 3, Umboniso 4:66

Vukile went to the shop with Nomvuyo? The two of them? Why have they gone to the shop? Who sent them both to the shop?

Act 3, Scene 4:66

Mvuzo decides to leave them alone. Lizeka does not allow him to go because he is also part of the solution of the problem. Vukile and Nomvuyo arrive. Mvuzo leads the discussion. Madoda and Vukile still claim that Nomhle is theirs and that they both paid. They are shocked because each of them thought that Nomhle and the child belong to them. They want to fight again. Nomhle tells them that she still does not know who the father of the child is. Mvuzo wants Nomhle to choose one man. Nomhle tells Mvuzo that 
he is the cause of the problem, because he is greedy and he wanted to enrich himself at her expense. Mvuzo tells Madoda and Vukile that Nomhle is unfaithful. He is therefore not sure if there is anyone of them who is still interested in her . Vukile says:

Hayi mna mkhuluwa andisenawo.

Indima 3, Umboniso 4:66

No big brother, I am not interested.

Act 3, Scene 4:66

Madoda does not mind. He is prepared to be with Nomhle through thick and thin because he loves her. While wiping his tears, Madoda says:

Mna andikhathali nokuba kuyini na, ndiyamfuna uNomhle kuba ndiyamthanda. Andiyazi ke into eya kwenzeka xa kuthe kanti umntwana lo asingowam. Kodwa nokuba kunjalo ukuba uNomhle unokukhetha mna singabonisana ngokuba masimthini na umntwana lo.

Indima 4, Umboniso 4:71

I do not care at all, I want Nomhle because I love her. I do not know what will happen if the child is not mine. But even if circumstances turn to be like that if Nomhle chooses me then I will discuss the future of the child with her.

Act 4, Scene 4:71

Vukile is jealous now. He wants his girlfriend also. Mvuzo instructs Lizeka to look at the faces of the two men and note which one has big ears, small feet, big nose and a big forehead. Lizeka explains that it is Vukile who has all these qualities. Mvuzo and Lizeka now examine the child's body. They say the child looks like Madoda. Madoda gets excited. He is instructed to sit next to Nomhle and hug her. Vukile bursts out crying. He curses all women. Nomvuyo enters immediately and sits next to Vukile. She says to Vukile:

Sithandwa sam ndiyivile yonke into ebithetheka apha. Xa imeko sele inje akusekho mfuneko yokuba sibafihlele abantu le nto yethu 
My love, I heard everything here. Seeing that things turn out this way then let us be open to them about this thing of ours.

Act 4, Scene 4:73

Nomhle stops crying and looks at Vukile and Nomvuyo in disbelief. She asks if Nomvuyo is in love with Vukile. Nomvuyo explains that the affair started only when they were on their way to the shop. Vukile, she says, feels that Nomvuyo is the one who has the qualities of being a wife because she is clever. Nomhle becomes angry. She curses all men for not keeping and honoring their promise. Madoda is angry that Nomhle is still jealous of Vukile. Mvuzo explains that it is because Madoda has not yet kissed Nomhle. Madoda then kisses Nomhle and she becomes excited.

Mvuzo addresses them. He suggests that everything is now solved and they must become friends. Mvuzo wants to know if Vukile is serious about his affair with Nomvuyo. Vukile says he wants to marry Nomvuyo because she does have qualities of a wife. Nomhle is concerned about Vukile's family. Vukile says that is not a problem at all because the people who came to see the child told him that the child is not his and the snake is not a Majola snake but an inkwakhwa. It was Vukile who was busy forcing mothers because of his love for Nomhle. He feels that his family will be pleased if he comes back with another girl. The only problem is the money which is already paid to Nomhle's family. Vukile says that his father will demand money.

Mvuzo assures him that it is not a problem because they are ready for everything. He further explains that he, Nomvuyo and Lizeka were behind all the events of that day because they wanted to solve Nomhle's problem. Mvuzo gives Vukile back all the money and Vukile is content. Vukile enquires from Nomvuyo about the convenient day for the arrival of the marriage negotiators. Nomvuyo is excited.

Nomhle reminds her brother that he must also send marriage negotiators to Lizeka's home. She feels that they owe her a lot for brilliantly solving their problem. Nomhle suggests that they can come on the same day with Madoda's family, in the morning and in the afternoon. Mvuzo says that he is not yet ready. Ultimately Mvuzo agrees and they are all rejoicing with each other. The women each serve up food for their men. 


\subsubsection{Analysis of plot structure}

The plot structure can be divided as follows:

a) Desperate situation of Nomhle and Mvuzo with Nomhle pregnant

b) Paying of damages by two men

c) The birth of the baby and visits by people of the men

d) Plot of Lizeka and Nomvuyo with meeting of the two men

e) Solution to problems: everyone gets married

This drama is a farce. Davis (1970:1) explains that farce is a particular sort of comedy which has for its sole object to excite laughter. It is intended solely to entertain. $\mathrm{He}$ elaborates by saying that:

Both the Greek and Roman stages seem to have distinguished between various forms of comedy according to their subject matter than their appropriate comic styles.

Davis (1970:6) suggests that farce can be characterized by negatives - the more exaggerated characterizations, the cruder coincidences and the grosser pieces of joking belong to the farce, while the more sophisticated elements of plot, character and theme are those of comedy proper.

According to Davis (1970:7) being short and often episodic in structure, farce is by nature suited for this role of filling gaps in longer dramatic programmes. Furthermore, he avers, its name is actually derived from the Latin fairce, to stuff.

One of the characteristics of farce is that it embodies a more tolerant attitude towards man's stupidity. It also restricts itself to a more generalized kind of comic mimicry thus proving a more long-lasting vehicle for lively fun.

Shroyer (1970:21) shares Davis's views when he observes that in treating the general ridiculousness of man and his predicament, farce portrays for the most part the distracters that are reduced to the level of common humanity. In farce, he concurs, the characters 
become involved in events that get out of control and these events in drama are called "situations". He provides us with his explanation of a farcical situation.:

... the farcical situation is an extremely artificial one - a situation resulting from or based on something like a mistake, or a disguise or a lie. Hence, mistaken identity is a common ingredient in this kind of comedy.

Both Davis (1970) and Shroyer (1970) agree that in farce, the subject matter centers around everyday, middle-class life - life replete with worries large or small, guileful schemes clever or inept, little deceits cunning or maladroit. Common in farce is also the concerns with matters of money and sex, preferably both. One shares Shroyer's views when he observes that mankind in general, when involved in affairs of money and sex, is almost invariably portrayed as bluffing, or pretending, or deceiving, or cheating. It is for that reason therefore that many of the characters in farce are filled with fear - a fear of being thwarted, or a fear of being caught, or a fear of being punished. Sometimes, Shroyer (1970:22) elaborates, the characters in farce are filled with joy - the kind of joy that accompanies the planning of supposedly foolproof schemes, or the kind that results when petty gratification is realized, when hungered for success is achieved. He mentions an interesting point about the characters in farce, that they are filled with exasperation as complication builds upon complication, obstacle builds upon obstacle.

A few main comic controls or keys are identified. These are exaggeration of body characteristics and exaggerated reactions. It is evident that virtually everything is exaggerated - emotions, misunderstandings, gestures, speech and dialects. Shroyer $(1970: 22)$ notes another important farcical device. That device is repetition - the repetition of situations, of movements, of gestures, even repetition of characters. Variations on a theme, he observes, always heighten the comic effectiveness of repetition.

Having explored various characteristics of a farce, so clearly there are signs of a farce in this drama. The plot structure of this drama as tabulated above is very simple. There are two lovers, Madoda and Vukile who are both accused of one pregnancy, that is Nomhle's pregnancy. The non-conservative way of paying Nomhle's damages is also worth noting. Mvuzo, Nomhle's brother, does this on his own. He does not involve the other male family members. He goes himself together with Nomhle to the homes of these lovers. The behaviour of both lovers in both homes is very strange. There is obvious gladness and 
love of both lovers at the time of the visit to their places for damages. There is a lot of cheating, deceiving and pretending in this drama which is typical of a farce.

In hesitation, Nomhle is filled with fear - a fear of being thwarted, caught and punished. As payment of damages is done at her home, Nomhle is fearful of being caught by the other lover who has already paid damages. On the other hand, Mvuzo is not bothered at all because of hunger for success. He is greedy. Nomhle is fearful of being caught again during the examination of the baby for parenthood. In this drama, as complication builds up complication, obstacle builds upon obstacle. The presence of the snake complicates matters. At first the family of the lover felt that the baby was not theirs, but the presence of the snake changed their minds though they were divided on this issue. The others felt that it was another type of snake and not the one of the Majola clan. The marriage proposals of both lovers complicate matters further.

Farce centers around everyday life like affairs of sex. Lizeka has an affair with Mvuzo and Nomvuyo has her eye on Vukile. In this drama one identifies guileful clever schemes as well as little cunning deceits. Lizeka and Nomvuyo plot to get Nomhle's two lovers together. Their aim is to solve Nomhle's problem of not being able to choose from the two lovers but at the same time this is done to help Nomvuyo who has no boyfriend. This is no doubt a farcical situation based on a disguise and a lie. Lizeka and Nomvuyo think about writing letters to Nomhle's boyfriends calling them to a meeting in the Noqaza forest. Madoda and Vukile came at the same time but do not know each other. Lizeka and Nomvuyo hide to see from a distance how their plan will work. Madoda and Vukile meet with two girls fetching water and Lizeka and Nomvuyo organize even this meeting. The two men try to entice the two girls thus trying to make Nomhle who has delayed to honour the appointment, jealous. On the other hand, Lizeka and Nomvuyo draw Nomhle's attention on her lovers who hug other women. Nomhle who is described as being a jealous lover arrives immediately and there are confrontations. Both men embrace Nomhle. They fight and Mvuzo arrives. He is shocked to see his girlfriend, Lizeka.

Clearly the above situation is accepted as good-humored fun of a farce which is most satisfying precisely when it invites violation of social taboos. It is not a hostile joke and as such it is far from losing its joyousness. 
One can argue that this is both a humiliation and a deception farce. Madoda, Vukile and Nomhle are victims here. They are subjected to explicit degradation. On the other hand this farce can also be referred to as the deception farce. Its victims are allowed to remain happily blind to the fact that they have been outwitted. At the end of the drama, reconciliation of some kind is indeed sought by practical jokers. Nomvuyo seduces Vukile and they marry finally.

In the ultimate solution of the problem of Mvuzo's place, Nomvuyo and Lizeka know something the other characters are unaware of and when at the end of the drama they produce their knowledge, everything resolves into harmony. Nomhle, Mvuzo and Nomhle's boyfriend are not aware that Nomvuyo and Lizeka's plan is to solve Nomhle's choice of a husband and then Nomvuyo gets the rejected one. From another angle, the drama's maneuvering us into a state of emotional detachment can be seen as an enabling of intellectual engagement, hence the title of the book, lintombi zinecebo. The two characters, Nomvuyo and Lizeka use their brains in solving Nomhle's problem. Let us not forget that to borrow from Toliver (1969:208) life is a tragedy to the man who feels, a comedy to the man who thinks.

At Mvuzo's place both men are still prepared to marry Nomhle. After Mvuzo's explanation of Nomhle's unfaithfulness, Vukile withdraws. They start comparing the baby's features and they realize that the baby is Madoda's. Nomhle cries when Vukile and Nomvuyo said they love each other. Madoda kisses Nomhle and now she is satisfied. All of them now will start marriage negotiations.

lintombi zinecebo is clearly a farce because even its characters are involved in events that get out of control. There is also a lot of exaggeration and repetition. There is repetition of situations as well as gestures.

\subsection{3 linkunzi ezimbini (H. Mothlabane, 1994)}

\subsubsection{Episodes}

\section{EPISODE 1: EXPOSITION}

In the expositional episode, the introduction, the reader (spectator) comes to know characters like Nolasti, Sigqibo and many others who will instigate the conflict on which the 
whole theme is based, as well as to understand reasons for its instigation. In Scene I we get to know Sigqibo, Nolasti's husband. It occurs at a funeral and almost all speakers voice their concern against women who kill their husbands. Ntungo says that men are afraid of their educated wives. He criticizes education, which does nothing for women of today and their marriages. Ntungo compares marriages of today's women with those of their mothers which were very strong. Nowadays, Ntungo explains, it is a well-known thing that men die first. He says things have changed because women demand their rights. Women do not want to be controlled by men anymore. Ntungo says that women forget that a household can have only one head:

Ntungo: ...khaniyiqonde into yokuba azinakukhonya zibe mbini ebuhlantini obunye, ikho eya kufa

Indima I, Umboniso I:3

Ntungo $\quad .$. you must understand that no two bulls can bellow in one kraal, because one will die.

Act I, Scene I:3

In scene II we see some indication that Nolasti, Sigqibo's wife, and Nolimithi, her neighbour are dissatisfied with their men who do not want to accept change. This is evident in Nolimithi's words:

Uthi ngamadoda ke phofu, izinto ezoyiswa kukumelana nokuguquka nje kwamaxesha?

Indima I, Umboniso l:3

Do you think these things are men, things who cannot accept change of times?

Act I, Scene I:3

The dialogue between the two women intensifies the action of the play. Through their dialogue we know what these two characters think about their men. This dialogue is the all-important means of characterization and it is remarkably adroit. 
Nolimithi tells Nolasti that she ridicules her husband immediately when he complains about women. Nolimithi says:

... Qha ke mna andimniki nentwana yethuba lokuba andiqhele ngobo bubhanxa, ndimphoxa zibekwa nje, abe manyonywana kwangoko.

Indima I, Umboniso 2:3

I do not give him a single chance so that he takes me for granted with those stupid things, I humiliate him immediately and he becomes embarrassed.

Act I, Scene 2:3

Nolasti and Nolimithi feel that their men treat women like objects and they plan to fight for their rights. Nolasti suggests that they must not bother themselves about this problem because it can easily be solved. They now plan to call and educate other women. Nolasti says:

Mna ndicinga ukuba xa sinokubashumayeza abanye abafazi abo, sibabonise ingxaki esikuyo thina bafazi, bangasebenzisana nathi ekothuleni le dyokhwe siyithwaliswe ngumendo. Isengenzeka ubona nje into yokuba baninzi abacinga njengathi qha bayoyika ukuzidandalazisa izimvo zabo.

Indima I, Umboniso I:5

I think that if we can preach the gospel to the other women, and show them their problem, they can co-operate with us in shaking off the yoke put on us by marriage. It is possible that there are many who think like us but they are afraid to give voice to their views.

Act I, Scene I:5

Nolimithi thinks that women do not realize that their men oppress them. They think instead that they are oppressed by their mother-in-laws. Nolasti and Nolimithi decide to return to their homes because they are still going to cook for their husbands and families. Nolasti believes that this in itself is oppression of women. She explains that they are all tired as they are coming from the funeral but it is women who are supposed to cook, tired as they are. 
In Scene 3, there is further highlighting of women's oppression and submissive wives. Nofinishi, one of Sigqibo's wives feels that she must quickly cook for her husband, because he will be starving by the time he comes back home from the funeral. Nolasti tells Nofinishi that they are all tired and as such they must rest. She rests immediately thereafter. Nokhaya, Sigqibo's other wife tells Nolasti that there is no time to rest. Nolasti confronts them for treating Sigqibo like a god. Nofinishi explains that they are not afraid of Sigqibo. They respect him. Nofinishi uses the wives' hlonipha language and Nolasti laughs at her. Nofinishi believes that Sigqibo is the head of the family. She says:

Simhlonele thina uJwarha kuba uyityhontsi yeli khaya

Indima I, Umboniso 3:7

We respect Jwarha because he is the head of this family.

Act I, Scene 3:7

The word tyhontsi is the word of the hlonipha language used by married women. It means a head. Nofinishi is surprised that Nolasti knows nothing about the hlonipha (respect) language and yet she claims to be a married wife.

Sigqibo arrives and Nofinishi goes out quickly. Nolasti is remaining cool and calm. It is as if nothing is happening. Sigqibo confronts Nolasti about chatting instead of working. He demands coffee because he is tired. Nolasti tells him that she is also tired. Nofinishi and Nokhaya will bring him coffee. Sigqibo forces Nolasti to bring him coffee and Nolasti defies him. Sigqibo is angry and he goes straight to Nolasti. Nolasti goes to the door in order to run away from Sigqibo. She pushes Sigqibo and tells him that she is tired and has no time for what he is saying. Sigqibo does not believe what is happening. He says:

Yeyiphi ke ngoku le? Kutheni ingathi uya ethath'unyawo mihla le nje lo mfazi? Tyhefu ni le ayincancayo kula makhitshi aba beLungu? Andisenakufuna nekofu le kodwa ndinomfazi. Sendixelelwa nguye ukuba mandithume abanye abafazi yena uyintoni?

Indima I, Umboniso 3:8

What is it now? Why does it look like this woman is excelling in her behaviour everyday? What poison does she suck from these "white kitchens"? I cannot even ask her to make me coffee although she is my wife. I am instructed by her to send for other wives, what is she? 
Sigqibo is interrupted by Nokhaya who brings him coffee. From this point onwards, conflict is indeed possible and its birth is clearly suggested in Sigqibo and Nolasti's violent argument.

Sigqibo meets Gcisa with whom he discusses their clashes with women. He complains that he had never argued with women, but ever since he married Nolasti then he is always involved in arguments with women. He believes that her employers influence her. Gcisa tells Sigqibo that women nowadays are fighting for their rights and they forget that two bulls cannot bellow in one kraal.

In this episode, all the characters who will play a major part in the drama are introduced, as well as the reasons for conflict. Based solely on this, this episode is then considered as an effective introductory episode.

\section{EPISODE 2: MOTORIC MOMENT}

Episode 2 is the motoric moment and it concerns women who discuss the way they are badly treated by their husbands. These women are Nofinishi and Nokhaya. They talk about Nolasti as well, critisizing her for not obeying their husband. They feel that they are ill-treated because of Nolasti's behaviour. Nolasti, according to them, does not respect her husband and this "causes" his ill-treatment of them.

In Act 2, Scene I, Nolasti is at her work place with Mrs White and they are chatting. Mrs White tells Nolasti she will be going out with her husband to a dance. Nolasti wants to know if they hold each other in full view of the other people when dancing. Nolasti is astonished when she learns this. She envies them because in her culture that is a disgrace and she does not understand why. On her way home, Nolasti meets her husband. She tells him that she will be babysitting her employers' baby as they will be out for the evening. They promised to give her more money for the overtime. Nolasti accepts the offer because she wants to buy winter clothes for her children. The other money will be used for the payment of the medical bills of Sigqibo's mother. Sigqibo confronts Nolasti for making a decision with her employers without consulting him. 
They argue and Sigqibo tells Nolasti to keep quiet because she is not the head of the family and as such she has no right to argue with him at all. Sigqibo does not want to be dependent on women even if he cannot make ends meet.

Nolasti does not understand why Sigqibo is reacting violently to her means of trying to improve their working conditions. Nolasti says:

Ndizuza ntoni ke ngaloo mizamo ngaphandle kwentiyo kaSigqibo nabafazi bakhe?

Indima 2, Umboniso 3:19

What do I get for my efforts besides being hated by Sigqibo and his wives?

Act 2, Scene 3:19

Nofinishi arrives as Nolasti is busy talking to herself. Nofinishi tells Nolasti that Sigqibo is always violent because of her and as such she must do something about it. Nolasti reminds Nofinishi that they must be grateful and not treat her badly because she is taking good care of them. She supplies their families with food and clothes because they are poor. Nofinishi says that they are poor because Sigqibo paid a lot for Nolasti's lobola as she is educated. They exchange bitter words and Nolasti reminds them that she is married to Sigqibo legally unlike the others who are common law wives.

On the following day, Nolasti visits their priest and his wife. Nolasti confides to them that there is no peace at her home. She is always quarreling with her husband and his wives. She wants to be advised. Nolasti tells the priest that they quarrel about rights. Her husband, she explains, wants to take decisions for other people. He does this against their will and Nolasti is referred to as a troublemaker.

The priest does not understand why Nolasti does not want her husband to decide for her. He says:

Wena ke uyifumana inzima phi into yokwamkela izigqibo zomyeni wakho? Yintoni ebangela ukuba wale ukuthathelwa izigqibo yindoda yakho? 
What is difficult in accepting your husband's decisions? What causes you to refuse decisions taken by your husband on your behalf?

Act 2, Scene 4:22

The priest's wife does not agree with her husband. She believes that being objectified by someone with whom you live is bad. Nolasti adds that she makes a large contribution to her household's finances and as such she must have a say in all decisions. The priest does not share Nolasti and his wife's views of liberated women.

\section{EPISODE 3: COMPLICATION}

Episode 3 is the complication. It fulfils the earlier depiction of the potential crisis. In church, women meet for their service. They discuss the way in which their husbands treat them. They say that they are objectified and treated like domestic animals. Nolimithi suggests that they must educate their husbands and tell them that the way they treat them is sinful. They complain about the way widows are treated by family members who take control of their household when their husbands die. After the service they all return home.

At Sigqibo's home, Nolasti wants to know from Sigqibo the reason why he does not want her to send their son, Luvuyo, to the school of her choice. Sigqibo does not want to argue with Nolasti about that. Nolasti argues that if Luvuyo studies at Macubeni then he will be deprived of other important life skills. According to Sigqibo if Luvuyo studies in another school then he will copy bad behaviours of the other students and moreover Sigqibo has never been to Alice. They argue and Sigqibo threatens to force Nolasti out of her job which he believes poisons her. Sigqibo says:

Ungumfazi into oyiyo yaye andizukuva ngawe kuba unemali oyisebenzayo. Uya kuba nengqondo mhla ndakukhupha kuloo msetyenzana wepeni, uhlale apha ekhaya, ufane nabanye abafazi aba bayaziyo indawo yabo.

Indima 2, Umboniso 5:29

You are a woman and I will not be controlled by you simply because you are working and you do have some money. You will have brains the day I take you out of that job and stay at home just like other women who know where their place is. 
Nolasti is still prepared to send Luvuyo to Alice. She demands that her voice be heard in her household. She says:

... ndivumele ukuba ndibe nelizwi kulo mzi, ngowam nam.

Indima 2, Umboniso 5:29

... allow me to have a say in this home because it is also mine

Act 2, Scene 5:29

Nolasti challenges Sigqibo to go ahead with his threat of forcing her out of her work. She further explains that she wants to be involved in various decisions of her household. Sigqibo fails to understand Nolasti's demands because the other wives before her never had a problem when they were not involved in decision-making. He highlights Nokhaya and Nofinishi who are happy in their household because they know where their place is. They do not complain at all. Sigqibo apparently enjoys being with them because he does not become involved in wars over their rights, unlike when he is with Nolasti.

Sigqibo decides to leave Nolasti but Nolasti does not want him to leave because she misses him. Nolasti tries to persuade Sigqibo to spend the night with her:

Yhini wethu sithandwa, ngoku besendizithembise ukuba uza kulala apha namhlanje. Sowuxola kaloku ulale, andizukuthetha nto ngemfundo kaLuvuyo

Indima 2, Umboniso 7:30

O my dear, I have already promised myself that you will spend tonight with me. Forgive me and sleep, I am not going to talk about Luvuyo's education.

Act 2, Scene 7:30

Sigqibo takes his jacket forcefully from Nolasti and leaves her. Nolasti looks through the window and sees him going to Nofinishi's house.

Sigqibo chats with his sons Mandla and Luvuyo. Luvuyo asks his father if respecting chiefs nowadays is of any use. Sigqibo tells Luvuyo that chiefs are pillars of the nation. $\mathrm{He}$ tells his sons about changes in our lives nowadays. According to Sigqibo it is important for people to respect those above them. Children must respect their mothers, 
mothers respect their men, men must respect their chiefs, and chiefs must respect their ancestors. Sigqibo suggests that holding onto that ladder can prevent the nation from falling.

In Scene 8, Sigqibo's three wives are sitting together. They talk about Nolasti and Sigqibo's fight over Luvuyo's choice of school. Nolasti expresses her anger because she cannot advise Sigqibo. Nokhaya tells her that whether they agree or not with Sigqibo they simply keep quiet. That kind of reaction tames Sigqibo. Nolasti wants them to correct Sigqibo; she insists that is their right.

\section{EPISODE 4: CLIMAX}

Episode 4 is the climax. As Nolasti is busy preparing to go to sleep, her husband arrives. He asks for meat and Nolasti is not prepared to give him meat. She accuses him of sitting next to the kraal while she was busy cooking meat. Moreover, Nolasti says that she is busy preparing to go to sleep and she does not have time to cook meat. Nolasti says:

Uyabona kodwa ukuba ndilungiselela ukulala ngoku? Uthi mandiyeke le nto ndiyenzayo ndenze le ifunwa nguwe, ngeli xesha uvifuna ngalo?

Indima 3, Umboniso 2:38

But can't you see that I am preparing to go to sleep now? Do you think I must stop what I'm doing and do what you want at your convenience?

Act 3, Scene 2:38

Sigqibo asks if Nolasti has forgotten that she is a wife and Nolasti says that may be she has forgotten because she last saw him long ago at her house. Nolasti thinks that Sigqibo decided to visit her because he is hungry. Sigqibo becomes angry and beats Nolasti with a stick. Nolasti cries bitterly at the top of her voice and runs away.

The following day, Nolasti tells her employer, Mrs White, about her quarrel with Sigqibo. Mrs White takes Nolasti to the doctor because she is injured. Against her better judgement Nolasti is persuaded by the doctor to lay a charge of assault against Sigqibo. She informs Mrs White that it is not right for her to lay a charge against her husband. Sigqibo is convicted but later she withdraws her charges because she does not want to be 
divorced by her husband. Nolasti informs her employer, Mrs White, that she does not want to be lonely. Mrs White responds by saying:

I'm disappointed Nolasti, I have always thought you liked the idea of being a liberated woman.

Act 5, Scene 5:68

Furthermore, she says:

I'll never understand them. Just when you think they are improving, and they plunge back into their old foolish ways!

Act 5, Scene 5:58

\section{EPISODE 5: DENOUEMENT}

Episode 5 is the denouement. The resolution (asking or untying) or denouement (untying) is the finishing of things after the climax. Once the "untying" begins there is no more suspense. Nolasti is forced to go home because laying a charge against her husband is a disgrace. MaGaba, Nolasti's mother confronts her, saying:

Kukangaphi ndikuxelela mntwan'am ukuba ayidalwanga into yokuba kukhonye linkunzi ezimbini ebuhlantini obunye?

Indima 5, Umboniso 3:64

For how long must I tell you, my child, that it is not natural that two bulls bellow in one kraal?

Act 5, Scene 3:64

Even Madoda, Nolasti's brother, agrees with his mother. He believes that Sigqibo's actions are quite right because he has long been pushed too far by a woman. He believes that women must be submissive and accept men as heads of families.

After a while Nolasti decides to go back to Sigqibo and asks for forgiveness. She suggests that she can simply stay at her house so that they stay married even if there are still problems between them. 


\subsubsection{Analysis of the plot structure}

Mothlabane's drama may be evaluated according to various phases:

a) Ntungo and other men's dissatisfaction about women's fight for their rights. One of Sigqibo, the headman's wives, Nolasti, is the leader of those women. Ntungo believes that no two bulls can bellow in one kraal because one will die. On the other hand Nolasti and her group despise men who do not accept change.

b) Sigqibo's other wives are satisfied with the way things are. They oppose Nolasti's views who try desperately to change them. They discuss the way they are being illtreated by their husbands because of Nolasti's behaviour. They feel that Nolasti is being influenced by her white lady employer because according to them, white women have their own way of treating their husbands.

c) Nolasti's conversation with Mrs White, her employer: They compare their cultures. Nolasti is impressed with Mrs White's culture. She agrees to baby-sit while the couple goes out for a dance. Sigqibo gets angry because Nolasti did not ask for permission from him. Sigqibo and Nolasti quarrel because he feels that he can take good care of his family without Nolasti's overtime.

d) Sigqibo's other wives confront Nolasti about their husband's bad temper lately.

e) Nolasti is depressed and she visits her priest for advice. There is no harmony at her place. They fight everyday. She feels that the cause of the problem is fighting for her rights which is not accepted by her husband. The priest feels that Nolasti is wrong and she is supposed to listen to her husband. The priest's wife shares Nolasti's views. She feels that Nolasti should be part of the decision-making at home. The two women explain that even the priest himself is an oppressor instead of a supporter of the oppressed. They plan to organize a meeting for women. All women in the meeting cry for their rights and they plan to act.

f) Sigqibo and his wife, Nolasti quarrel about which school their child, Luvuyo, should attend. This happens at Nolasti's home and Sigqibo decides to go to the other more submissive women's houses. 
g) Sigqibo visits Nolasti one night. They quarrel again and he beats her. She informs her employer who takes her to the doctor. Sigqibo is arrested at the doctor and Mrs White's suggestion. Nolasti later withdraws her charges because she does not want to be divorced because she will be lonely and disgraced. Nolasti is forced to go to her parents' home. Her mother and brother confront her. After some time, she asks for forgiveness from Sigqibo so that they stay married.

This drama's expositional episode is well orchestrated because one identifies clues which instigate the whole conflict on which her theme is based. Speeches on various issues especially women's rights and male-dominance are made. The author's male characters complain about female characters especially their wives who believe in an androgynous society that is based on a social system wherein neither women nor men dominate. According to these women characters, both sexes are equally powerful in all spheres of life.

In her theme, the author is concerned with arrangement and shape. Her theme does follow the part-by-part unfolding of the argument. The protagonist Nolasti is always at loggerheads with her husband because of differences of opinion. At some stage, she becomes depressed because she is confronted by her husband's other wives. They do not support her and she turns to the priest's wife for comfort and advice. Things become complicated because Nolasti is empowered by Mrs White, her employer whose culture is different from hers. This leads to a lot of violent confrontations until her husband injures her. This leads to the climax because Nolasti is advised by Mrs White to lay a charge against her husband for assault. It is not clear why Nolasti decides to withdraw a charge against her husband and yet all along she is talking about women's rights and oppression by men. Having laid a charge against her husband, Nolasti is forced to go to her parent's home, but decides to come back to her household. That is very much unlike the strong character she has been portrayed to be.

The plot structure of this drama is poor, because the aim of the author is to depict her theme on women's rights as well as a clash of cultures. She has exaggerated a lot of actions by Nolasti. She is not successful in sustaining excitement and tension in her play. As one reads the play one cannot avoid observing the lack of coherence of events from scene to scene towards the end of the drama. 


\subsubsection{Yeha-a mfazi obulala indoda (L.L. Ngewu, 1997)}

\subsubsection{Episodes}

\section{EPISODE 1: EXPOSITION}

Episode I of the drama serves as an introduction. In Act I, Scene I, we observe Nozinto anxiously phoning her friend Zodidi very late at night. She informs Zodidi that at last she has finished that thing she once briefly told her about. She elaborates that she is free now and she is happy that it is over. The story focuses on Nozinto, who has a well-defined goal. Her goal is to get rid of her husband who has long been ill-treating her. Nozinto says:

(Ewavule aziingqanda amehlo)

Yehee, ntombi! Mamel'apha ndikuxelele. Ndide ndayiqabelisa laa nto ndandikhe ndakuthela thsuphe yona. Ndikhululekile ngoku yaye qabu uNoqolomba efile nje!

Indima I, Umboniso I:1

(Her eyes wide open)

Hey! Girl, listen, let me tell you something. I have finished doing that thing I once confided to you about. I am free now and I am glad it is over.

Act I, Scene I:1

Events of the first episode are influenced by Nozinto's actions because she has long been setting out to avenge herself on her husband, Zamile, who has been oppressing her by infringing on her rights as a woman. As Ngewu's plot progresses, it arouses expectations about the future course of events and how characters will respond to events.

Zodidi is confused, because Nozinto is always controversial, as her name suggests, and as such it is very difficult for her to guess what the problem might be. Moreover, Zodidi is surprised because it is late at night for her to travel to Nozinto's place. When Nozinto tells Zodidi to fetch her other friends, Phalisa, Nconyiwe and Nozinga on her way home, Zodidi thinks that Nozinto is drunk. Eventually Zodidi agrees and she travels with the three friends to Nozinto's place. On the way, they try to guess what Nozinto's problem could be. 
We gather from the conversation of these characters that Nozinto is not on good terms with her husband. Apparently this has been the case for a long time. Zamile is a womanizer who does not respect his wife. He is a professional dancer and is in love with one of his dance partners. Nozinto, who is always lonely at home, has started to drink to console herself. Nozinto once shared her problems with her friends. Nconyiwe explains that Nozinto once hired assassins to kill her husband. Fortunately for Zamile, the wouldbe-assassins realized that they knew him since he is a well-known professional dancer. They could not kill him. Nconyiwe feels that Nozinto is a greedy woman. She knows that the day her husband dies, then she can inherit everything. Nconyiwe says:

Zininzi zona izinto anokumbulalela zona. Eyokuqala uyarhala laa mfazi akazenzi. Andiqondi ukuba kukho into angayirhaleliyo apha elizweni. Uyazi ehleli kulaa ndawo ukuba ukufa kwendoda yakhe zininzi izinto anokuzifumana.

Indima I, Umboniso 1:3

There are many things for which she can kill him. Firstly, that woman is greedy and she cannot help it. She wants everything in this world. She knows quite well that the day her husband dies, she can inherit so many things.

Act I, Scene 1:3

Nconyiwe further explains that Nozinto has been telling her that she does not like living in the township. She wants to have a home in the suburbs, especially as her friends have homes in the suburbs. The suburb, which Nozinto prefers, is Port Shepstone.

Nconyiwe does agree that a wife can kill a husband if he cheats on her. Zamile is believed to have two wives because he is said to have proposed marriage to another woman and that they are about to get married. He does this though he is still married to Nozinto. Zamile does not spend time with his wife at all. Zodidi angrily says that Nozinto married Zamile knowing that he is a professional dancer. She feels that Zamile cannot tolerate a drunkard especially because he does not drink. Zodidi is one of those submissive women who feel that in marriage a woman must be humble to her husband.

Phalisa tells her friend that Nozinto is in love with a policeman and that they must empathize with her situation because she does not get all her marital rights from her husband. Phalisa says: 
Akayenzanga loo nto kuba engakwazi kuziphatha koko ubethwe kukuphela komtshato. Xa uZamile emfulathele umfazi wakhe, mvumeleni uNozinto aye apho anokufumana khona uhoyo.

Indima I, Umboniso 1:5

She is not doing that because she does not know how to satisfy herself, but because of her marriage, which is on the rocks. If Zamile turns his back on his wife, then allow Nozinto to go where she can get attention.

Act 1, Scene 1:5

Phalisa warns her friends that a man does not have a right to do as he wishes because he is a man. Nozinto is also a human being. She has feelings just like Zamile. Phalisa says:

Masahlukane nento yokucinga ukuba indoda inelungelo lokwenza nokuba yintoni na kuba nje iyindoda.

Indima I, Umboniso I:5

Let us do away with this habit of thinking that a man has a right of doing as he wishes because he is a man.

Act I, Scene I:5

The long conversation of these characters who are called by Nozinto in the middle of the night is a subtle technique by the playwright to sustain suspense. An element of conflict or point of attack is introduced. Ngewu, the playwright, makes use of extraspective means because he refers to certain incidents, which are not dramatized.

Nozinto's friends arrive at her home with all those unanswered questions. From now on we expect things to develop dramatically. Nozinto confronts them for coming late. She tells them that thugs have murdered Zamile and that she has not yet informed the police. Their dramatic dialogue compels the plot further by linking the one unit of action, that is the murder of Zamile to Nozinto's arrest. Nconyiwe phones the police. She reports that she suspects the wife is the suspect. Nozinto tells her friends that she suspects that the cause of Zamile's death has something to do with his behaviour - he is a womanizer. Zamile is not dead yet and an ambulance takes him to the hospital.

Zodidi is surprised that there in not a single man who comes to help them take Zamile to the hospital. Nozinto is certain that the condition in which Zamile is shows clearly that he 
will not pull through. Nozinto's friends decide to leave and Phalisa, Nozinto's best friend, decides to stay behind with Nozinto.

On their way home, Nozinga, Nconyiwe and Zodidi discuss the murder of Zamile and Nozinto's suspicious behaviour. Nconyiwe blames Zamile and Nozinto who both have extra-marital affairs.

Through characters like Phalisa, Ngewu introduces, as Ngozi (1994:266) puts it, a discourse of gender that aims at correcting the patriarchal location of women at the margins of society. He creates speaking women, who criticize their society's depreciation and distortion of women's suffering and their frightening experiences.

Nozinga is totally against Nozinto's cruel behaviour of killing her husband. She remarks:

Yeha-a-a umfazi obulal'indoda

Indima I, Umboniso I:12

Woe to the woman who kills her husband

Act I, Scene I:12

Zodidi, Nozinga and Nconyiwe discuss the reasons why Nozinto was not arrested when she first attempted to murder her husband. We gather that the investigating officer of Nozinto's case was Nozinto's lover and the case was closed.

Nconyiwe reminds her friends that Nozinto's cruelty is the result of her husband's behaviour and ill-treatment. Nozinto cannot tolerate it anymore. Her treatment sows seeds of hatred. Her husband's actions turn her into a drunkard, a prostitute and a killer.

When Nozinto falls in love with a policeman after having been deprived of her rights by her husband, she is looked down upon because she is not supposed to do as men do. Nozinto is depicted as a bad woman even in her name which refers to someone who is controversial.

The seeds of hatred planted by Zamile's treatment are evident in Nconyiwe's dialogue. She says: 
Andifuni kodwa isisithele into yokuba uNozinto ade angcole ngolu hlobo nje wenziwe nguZamile 10. Ubenyanisile uPhalisa laa nto ebeyithetha kodwa khange ndifune ukubonakalisa ukuba ndiyahambisana nezimvo zakhe kuba loo nto ingamenza amkhuthaze kakhulu uNozinto ekugileni imikhuba

Indima I, Umboniso I:13

I do not want us to lose sight of the fact that Nozinto's cruelty is caused by Zamile. Phalisa was correct in what she was saying but I did not want to show her that I share her views. Lest she encourages Nozinto in doing bad things.

Act I, Scene I:13

Nozinga says that it is wrong for women to have extra-marital affairs and Zodidi does not share her views. Zodidi explains that even men do not have rights to have extra-marital affairs. The two characters now talk about the cause of the death of Phalisa's husband. It is clear that her husband, Manxiwa, who was running many businesses, abused even Phalisa. Manxiwa had many servants and he was in love with some of them. There was a young married woman who was also having an affair with Manxiwa and had two children by Manxiwa. This young lady was divorced because of this affair with Manxiwa. She was bitter because she knew very well that she had no future with Manxiwa who was married. Phalisa persuaded the young married lady to poison Manxiwa and promised to pay her. Apparently that woman still stays at Phalisa's place even as these women are chatting.

\section{EPISODE 2: MOTORIC MOMENT}

In Scene 4, the plot is developed yet a step further to the next episode which is the motoric moment. It is at Nozinto's home and she is with her friend Phalisa. They discuss the circumstances around Zamile's death. Nozinto drinks wine. Zamile is still in hospital and Nozinto is certain that he is going to die. They talk about the assassins who could not do the job of killing Zamile properly and professionally. Nozinto shows Phalisa her elegant dress for Zamile's funeral. The dress is black with white dots and Phalisa does not like the dots. She says that a dress for the funeral is supposed to be black without any other colour. Nozinto explains that the colour is quite right. The black colour is meant to deceive the people at the funeral. The white dots are a symbol of her freedom. She says: 
Akukho nenye indawo ephazanyiweyo kule lokhwe Le ndawo imnyama ilungiselelwe nje abantu bomngcwabo kungathiwa andilizilelanga idada lam. La machokoza amhlophe angumqondiso ofihlakeleyo wobunzulu benkululeko yam.

Indima I, Umboniso 4:20

There is not a single mistake in this dress. The black part is meant to deceive people at the funeral so that they think I am mourning my husband. The white dots are a hidden symbol of my freedom.

Act I, Scene 4:20

Nozinto's dialogue is a key device that activates women on their journey toward selfawareness and wholeness. Unfortunately she overreacts and does it in a very cruel manner because now she is excited as she is the beneficiary of Zamile's insurance policies.

Nozinto and Phalisa express their anxiety because they do not know what has been reported to the police by Nconiywe as she was reporting Zamile's murder. They hear the sound of a car and Nozinto pretends to be frustrated as she is waiting for the news of the death of her husband. The policeman enters. He is looking for Nconyiwe. The policeman wants to be shown Zamile's room because he wants to see him. Nozinto and Phalisa tell the policeman that Zamile's body has already been taken to the mortuary. The murder and robbery policemen now leave with Nozinto for investigation. They take Nozinto's black funeral dress as well.

\section{EPISODE 3: COMPLICATION}

The next scene which leads us to complication picks up the tension. Nozinto is interrogated. The policemen question Nozinto for not reporting her husband's murder to the police. They ask her if she cried at all when her husband was murdered. Nozinto tells the police that Zamile has many enemies and that one of his enemies is Nolutsha, his girlfriend. Although Zamile is not dead yet, Nozinto keeps on referring to him as if he were dead. One of the detectives, Sipho, furiously tells her that her husband is alive. Nozinto is imprisoned because she is suspected to have planned the murder of her husband. 
In her cell, Nozinto talks to herself. She vows to deny that she killed Zamile. She says that she will tell the investigators that as a woman she cannot kill a man. She says that women who kill their husbands discredit the status of women and as such they need to be hanged. She blames herself for confiding to Nconyiwe who reported her to the police.

The investigating officer, Sipho, goes to Phalisa to collect the keys for Nozinto's home. They are still busy with their investigation. Sipho questions Phalisa about Nozinto's black dress and the fact that Nozinto did not call her neighbours when Zamile was murdered. Phalisa asks if she can visit Nozinto in jail and apparently she can only visit her in the presence of the investigating officer.

In Scene 4, Sipho, the investigator visits Khomba, one of Zamile's neighbours. He asks if they know anything about Zamile's murder. He tells Sipho that he decided not to go to Zamile's home because they are always fighting. He further tells Sipho about Zamile's previous murder attempt. Nevertheless, Khomba did see the car which sped off from Zamile's home because he looked through the window when he heard shots. They plan to keep their meeting as a secret.

Sipho visits Zodidi at her home. Zodidi is with her husband, Zanazo. Zanazo tells Sipho that he knows everything and he has long been telling his wife to distance herself from that woman, Nozinto. Zodidi informs Sipho that Nozinto phoned her to say that she finally finalized the issue she once confided to her about. Zanazo shouts:

\section{Abafazi esinabo!}

Our women!

Zanazo's statement suggests that he finds the behaviour of women controversial.

Zodidi tells Sipho that she suspects that Nozinto could be involved in Zamile's murder. Sipho asks if Zodidi can stand as a witness in court. Zodidi refused because she does not want to be a sell-out to women. Many women, she says, are being ill-treated by their men in Butterworth and in other places, so she cannot stand against them. Zodidi says: 
Ndicel'uxolo kuloo ndawo, mhlekazi! Baninzi abafazi abahlutshwa ngamadoda abo aph'eGcuwa, nakwezinye iindawo. Ndingangumfazi ombi othengisa omnye umfazi.

Indima I, Umboniso 4:25

I am sorry sir, on that point! There are many women who are ill-treated by their husbands here in Butterworth and in other places. I can be labelled as a bad woman who betrays other women.

Act I: Scene 4:25

Zodidi's words demonstrate her unwavering support for abused women. Nozinto may be wrong in killing her husband, but Zodidi supports her cause.

Sipho visits Nozinto in her cell. He tells her about Zamile's death. Nozinto pretends to be devastated. She throws herself gently on the floor as she cries out:

Yhu! Yhu! Yhu! utat'abantwana bam besebancinci kangaka! Yintoni kodwa le indehlelayo? Yhu! Yhu! Yhu!

Indima I, Umboniso 4:27

Yhu! Yhu! Yhu! The father of my children who are still so young! What is happening to me? Yhu! Yhu! Yhu!

Act I, Scene 4:27

Nozinto is delighted to be released to prepare for the funeral. Sipho is surprised by Nozinto's behaviour because she is smiling broadly.

The dramatic tension mounts still further in the next act, Act 3, Scene I. It is before Zamile's funeral, three days after his death. Nozinto and Phalisa are together. Nozinto is pleased because there is no progress in Zamile's case. The investigating officer of the case now is a new person whom she claims still need to be trained in his work. The two friends enjoy themselves with wine. Nozinto is drinking heavily and Phalisa confronts her about that. Nozinto is triumphant because she has already received Zamile's insurance money. She is waiting for the assassins because she is ready with their payment and she wants to get rid of them once and for all. 
Nozinto behaves in a very cruel manner. She does not like the presence of Zamile's relatives. She complains that they eat a lot of food and apparently Zamile's parents have not arrived yet. Nozinto remembers that Zamile's father is very fond of him; he lovingly calls him Zam. She asks her friend Phalisa to tell her when she is supposed to cry:

Nozinto: Khawutsho, kufaneleke ukuba ndilile nini kakade?

Indima I, Umboniso 4:31

Nozinto: Please tell me when I am supposed to cry.

Act I, Scene 4:31

Nozinto suggests that she is supposed to cry when the coffin is lowered into the grave. Phalisa voices her fears that many people are very much aware of Nozinto's involvement in Zamile's murder. Phalisa's statement introduces us to the next unit of action, which complicates the plot still further. Nozinto is brave because she trusts that her witchdoctor will protect her.

Zamile's parents, MaNdlovu, his mother, his father, Lolwana, and other relatives arrive. They are devastated. Nozinto tells her in-laws to accept Zamile's death because it cannot be changed. They discuss funeral arrangements. Lolwana feels that when burying Zamile, a tradition has to be followed. If someone is murdered then nothing should be slaughtered. People should only eat cooked mealies. Nozinto refuses because she claims that people from different places and from all walks of life will be attending the funeral. That tradition needs to be done away with. Ultimately they agree with her.

Lolwana raises another cultural issue that women are not allowed to go to the graves of their husbands on the day of the funeral if he died by murder. He says:

Molokazana, akukho mfazi unokuma phezu kwengcwaba lendoda! Andinakuyivuma nje tu into yokuba unyana wam angcwatywe ngumfazi. Awazi ukuba bakhona abafazi abakhohlakeleyo. Into yokufa kukaZam, unyana wamazibulo, kungenzeka ukuba inento yokwenza nomfazi othakathayo. 
Daughter-in-law, no woman can stand next to the man's grave! I cannot allow my son to be buried by a woman. Don't you know that some women are cruel? It is possible that the death of my first-born son has something to do with a woman who is a witch?

Act 3 , Scene 2:48

Lolwana does not want to do away with this tradition of women who must be left behind when going to the graveyard. He explains:

Ngokwesiko lakwantu akuvumelekanga ukuba abafazi basondele edlakeni lomntu ofe ngengozi.

Indima 3, Umboniso 2:49

According to African tradition, women are not allowed to come close to the grave of someone who died by accident.

Act 3, Scene 2:49

Lolwana further explains that this is to make sure that women killers do not come closer to their victim. Nozinto asks what if her husband is to be buried by a female priest. Lolwana refuses:

Andinakuyivuma nje tu into yokuba unyana wam angcwatywe ngumfazi

Indima 3, Umboniso 2:49

I cannot allow my son to be buried by a woman.

Act 3, Scene 2:49

Lolwana explains that even if the killers were men, it is possible that they were under the influence of witches, who are women.

Lolwana sees a bottle of wine under Zamile's bed. When Nozinto leaves them, Lolwana draws the attention of his wife to the alcohol. MaNdlovu takes the bottle of wine and decides to put it in the wardrobe. She is shocked to find Zamile's bloody blankets. They see many bottles of wine and they are taken aback. MaNdlovu asks Lolwana to confront Nozinto about the bottles of wine. Lolwana refuses because he does not want to be hurt. 


\section{EPISODE 4: CLIMAX}

The next unit of action complicates the plot still further thus leading us to climax. People at Nozinto's home are busy preparing for the funeral. Women are busy discussing serious issues about the death of Zamile. They notice that Nozinto has vanished into thin air only to find that she has gone to the hair salon. She is concerned about her appearance on the day of the funeral. She is not mourning at all. Phalisa joins Nozinto at the place where Zamile was murdered. Nozinto plans to leave Butterworth immediately after the funeral because she does not want to be arrested. She plans to go to Port Shepstone where she plans to buy a house.

According to Phalisa, Nozinto looks beautiful and apparently there are men who are already admiring her. Nozinto says that if they want to be in love with her, then they must leave their wives.

On the day of the funeral, Nozinto follows the coffin being comforted by Zodidi. Zamile's children Noluvo, Sandi and Lolwakhe follow them. Zamile's parents follow these children. The priest conducts the service and speakers speak about Zamile.

As the priest is busy with the program of speakers, a plainclothes policeman goes to him and informs him that the accused is with them in church. The policeman orders other police to hold a short meeting outside. Khomba, Zamile's neighbour informs the congregation about circumstances around Zamile's murder.

The priest starts his sermon. He says that he is aware that Zamile's death has something to do with a woman. He utters the following words in his sermon:

Ndivile ukuba ukufa kukaZamile kunento yokwenza nomfazi. Yeha mfazi obulala indoda! Njengokuba inyoka yangena ngomfazi nje emyezweni, nenyoka ekukunyoluka iseza kulityhutyha-tyhutyha eli lizwe ikwenza oko ngokungena ngomfazi

Indima 3, Umboniso 2:61

I learn that Zamile's death has something to do with a woman. Woe to the woman who kills her husband. As the snake enters the garden of Eden 
through a woman, so will a snake which is greedy move about this world through a woman.

Act 3, Scene 2:61

The mourners are now ready to go to the graveyard, but before that the policeman wants to say something. Zodidi and Nozinto go steadily towards the door where three policemen await them. One of the policemen order Nozinto not to join the other mourners to the graveyard. They lead Nozinto to the police van, which is standing nearby. The policemen tell her that they want to finalize her husband's case in her presence. Nozinto cries. The people cannot believe what they see. Nozinto is taken to the East London police station by the name of Nongqongqo.

Nozinto is in jail and she speaks to herself. She thinks about committing suicide, but at the same time she thinks about her children who by now, do not have a father. She thinks about her female lawyer wondering if she can withstand men's strength in a court of law. Nevertheless, she has confidence in her especially if she is also ill-treated by her husband. She calls Zamile as if she is out of her mind. Nozinto says that she has long been patient with her husband, Zamile. She says:

Kunini ndamnyamezela uZamile!

How long have I been patient with you Zamile!
Indima 3, Umboniso 2:60

Act 3, Scene 2:60

\section{EPISODE 5: DENOUEMENT}

Our last episode is the denouement. Nozinto is still in jail. Nosiphelo arrives with Nozinto's children Sandi, Noluvo and Lolwakhe. Nozinto's children are confused. They want to know what their mother is doing in this place. They ask if their father is there as well.

Nozinto asks Nomaphelo why she organized a female lawyer for her. Nomaphelo feels that it is the female lawyer who will argue diligently because she empathizes with women. Nozinto is in a terrible state. She is wearing a dirty dress and Nomaphelo questions that. Nozinto complains about lice which fill her whole body. She is even becoming used to them. Nomaphelo tells Nozinto that her house has been vandalized. Everything has been stolen without a trace. She further explains that some waifs and strays have taken 
possession of the house. Nozinto's children do not even attend school. Nomaphelo explains that the society feels that her children are guilty by association. Nozinto's children demand to be left behind with their mother. They cry bitterly.

In court, Nozinto is charged with killing her husband. In her explanation of circumstances surrounding the murder of her husband, Nozinto enumerates the duties of an African woman. She says:

Njengomfazi kufuneka ndiphekele umyeni wam...

As a woman, I must cook for my husband...
Indima 4, Umboniso 1:67

Act 4, Scene 1:67

Nozinto further enumerates the duties of a woman. Amongst the things, it is the duty of a woman to cook for her husband, wash dishes and make sure that he has clean clothes to wear on the following day. She says that as a woman she is responsible for many things at home. The prosecutor asks if they do not have a helper and apparently they do not have one because Zamile used to have affairs with their helpers treating them as if they were his other wives. Nozinto explains in court that her husband was a womanizer. She further explains that her husband had many enemies. Nozinto complains in court that Zamile deprived her of her marriage rights. She says:

Mna ndiyingxwelerha yomtshato. Andisenguye laa Nozinto ndandinguye phambi kokuba nditshate. Ndingene zwabha kwizinto endandizicekisa kakhulu mandulo. Enye yezo zinto kukusela utywala. UZamile ebengasafuni nokulala oku nam kuba esithi ndinuka utywala.

Indima 3, Umboniso 2:72

I am a victim of marriage. I am no longer the same Nozinto I used to be before marriage. I am deeply involved with things I used to despise previously. One of those things is liquor. Zamile was no longer sharing a bed with me, because he was saying I smell liquor.

Act 3, Scene 2:72

The next witness, Khomba, Nozinto's neighbour is called. He explains about what he saw on the day of the murder and that he could not go to Nozinto's house because they are enemies. Nozinto's bad behaviour drove all her neighbours away from Zamile's home. 
Khomba decided to go and investigate at Nozinto's home and Nozinto banged the door in his face. Khomba further explains that Nozinto was not even crying. The lawyer asks Khomba if he cried after having realized what happened. Khomba explains that he does not cry because he is a man. It is women who are associated with crying.

The prosecutor points at Ntsiba and tells Nozinto that Ntsiba is the man who was asked by Nozinto to organize people to assassinate her husband. All the evidence shows that Nozinto did kill her husband. Funeral dresses, which were already prepared are mentioned.

Nozinto's lawyer suggests that there is also other evidence which needs to be looked at before wrapping up the case. Nozinto's lawyer goes to her and they talk. The lawyer suggests that for extenuating circumstances, Nozinto should tell the court that she was pushed too far by Zamile. Nozinto was extremely provoked beyond her capacity to endure. Nozinto tells her lawyer that she now has no confidence in her especially because the lawyer is a woman. She blames Nomaphelo:

Yhini! uNomaphelo ukundifunela igqwetha elingumfazi?

Indima 4, Umboniso 3:81

O No! Nomaphelo why did she organize a female lawyer for me?

Act 4, Scene 3:81

Nozinto and her lawyer are engaged in a violent confrontation. Finally Nozinto asks her lawyer to continue with the case. They need more witnesses. Nozinto has no confidence in her friends. As a last resort, they decide to call Nconyiwe as their witness. Nconyiwe demonstrates to the court the way Nozinto was ill-treated by her husband. Her husband, Nconyiwe explains, always abused Nozinto, physically and emotionally. However, the court has no confidence in Nconyiwe. They claim that Nconyiwe is part of the conspiracy. Nozinto's lawyer explains that in times of strains and stresses there is a limit to what a person can endure.

Nozinto is found guilty and she is not going to inherit Zamile's estates because a person who intentionally and unlawfully causes the death of the deceased is incapable of inheriting the estate of the deceased. A guardian for Zamile's children will then be appointed by the court to look well after the children. The day for passing the verdict is 
postponed till the following month. Nozinto cries bitterly, calling the names of her friends she phoned on the day of Zamile's murder.

\subsubsection{Analysis of the plot structure}

The episodes of the above drama can be divided as follows:

a) Telephone conversation of Nozinto and Zodidi and subsequent conversation of three friends in the car about Nozinto.

b) At Nozinto's home, Zamile is taken to hospital. Nconyiwe phones the police and informs them that Nozinto is a suspect.

c) Nozinto's friends drive home. They discuss about events at Nozinto's home as well as the murder of Phalisa's husband and the issue of extra-marital affairs.

d) Nozinto and Phalisa and discussion about funeral dress. Nozinto's interrogation and imprisonment. The investigation by Sipho with Phalisa, Khomba and Zodidi. Zamile's death and her release for the funeral.

e) Nozinto and Phalisa discuss events: Lack of progress in murder case, new investigating officer, wine-drinking by Nozinto, insurance money as well as the payment of assassins.

f) The arrival of Zamile's parents: funeral issues concerning presence of women and murdered persons, female priests, discovery of wine bottles and bloody blankets.

g) At the funeral ceremony: sermon of the priest, arrest of Nozinto, visit in jail by her children, circumstances at home and in jail: Nozinto and her children are separated.

h) In court: Nozinto is found guilty because there are no extenuating circumstances.

Ngewu's plot is structured very well and it is tightly organized. The progress of events in the different phases of the drama is very well controlled. One can clearly follow the unraveling of the plot through flashbacks of the friends of Nozinto. This drama is a tragedy and as such between the beginning and the end, a number of complications and confrontations occur thus building excitement and suspense. The events leading up to the 
climax and denouement are carefully controlled thus enabling the reader's attention to remain focused on the plot's development.

One admires the author's skill in handling a large cast of characters, his presentation of different realms of existence and the use of various dramatic devices, such as symbolism, flashbacks and other. His treatment of injustices against women and the theme of oppression, complexly interwoven with other elements, displays his potential as a developing dramatist.

\subsection{THEME}

In Mkonto's Emgxobhozweni the theme of women abuse is depicted. No-ankile, the protagonist is portrayed as a greedy character. She is also a devious character. Noankile is the second wife in her marriage and there is a daughter by the name of Nomonde from her husband's first marriage. They have businesses but the shop managed by Noankile is not making profits anymore, to her husband's frustration. He suspects that Noankile and her friends could be the cause of the problem. No-ankile's husband always boasts about Nomonde's shop, which is flourishing. No-ankile is not involved in some of their household issues because she is portrayed as someone who is jealous of Nomonde and as a result it is Nomonde who is always consulted concerning their household affairs.

In Mothlabane's linkunzi ezimbini the theme of the drama is about women abuse also. Nolasti is married to Sigqibo who has other wives also. She is always at loggerheads with her husband because she challenges him in many things. Sigqibo believes that he is a head of the family and as such he must have a say in everything at his home. Nolasti wants to have a say in her household affairs and she does not want to be objectified or subordinated. They quarrel also about the choice of their son's school and Sigqibo does not want Nolasti to have a say.

At one stage, during their quarrels, Sigqibo beats Nolasti and Nolasti's employer advises her to lay charges against her husband. She decides to go to her parents' home because she is despised not only by her husbands' other wives but also by Sigqibo's family. Nolasti does not get supported even from her family because she is reminded that she is not supposed to challenge her husband. She is supposed to be submissive. They further tell her that she is supposed to even lay charges against her for assault. In-laws are 
supposed to be consulted before such drastic actions are made. She decides to go home and Sigqibo does not even fetch her through the ukutheleka custom. It is as if he considers it good riddance. The author has succeeded in showing the dangers of following two different cultures. This is even suggested in the title of the book, linkunzi ezimbini (No two bulls can below in one kraal).

In Mcimeli's lintombi zinecebo a theme of abuse is also portrayed. Nomhle is abused by her brother Mvuzo. Nomhle is pregnant and she is not sure who the father of her baby is because she has two boyfriends, Madoda and Vukile. They are struggling at home and their late parents left them in debt. Mvuzo sees Nomhle's problem as a solution to the money problem because he demands payment from both men, Vukile and Madoda at Nomhle's expense. Nomhle is forced to tell to each that he is the father of her unborn child. They both pay and Mvuzo becomes rich and yet Nomhle is still left with the problem of not knowing whom the father of her child is. Because this is a farce, the problem is solved in a very humorous manner at the end of the drama.

Ngewu's drama Yeha-a mfazi obulala indoda is also characterized by women abuse. Nozinto's husband who deprives her of her rights as a married woman abuses the protagonist. Her husband is a professional dancer and most of the time he travels with other dancers and leaves Nozinto alone. It is even rumoured that he is in love with one of his colleagues and is going to marry her. Nozinto decides to have affairs as well. She even goes to the extent of hiring assassins to kill her husband. The first attempt is aborted, but the second one is carried out successfully but she is imprisoned and inherits nothing from her husband's properties because she is a killer.

\subsection{EVALUATION}

Some of the common themes in the dramas of this period are women's resistance against oppression. Women like Nozinto in Yeha-a mfazi obulala indoda do not approve of their husbands' involvement in extra-marital affairs. The issue is worsened when men abuse their wives physically when they confront them. Some women like Nolasti in linkunzi ezimbini are aware of the fact that dependency on men increases the women's exploitation by men. 
One is aware that during this period authors use their characters to express their messages and do this at the expense of other literary aspects, eventually coming up with stereotyped characters.

Some women characters reveal their beliefs about other women thus sharing men's views. Some male characters put all women under one blanket, saying that they are evil and murderous. Their generalizations are evident in Zamile's father who claim that women are witches and as such they cannot go to the graveyard. If one can pick up the negative terms in quotations from men speeches one may come to the conclusion that women are bad beyond redemption.

\subsection{COMPARISON OF THE THREE PERIODS}

\subsubsection{Plot structure}

Efforts by authors of the three periods to advocate change in society concerning injustices against women did affect their plot structures. The weakness has been the constant focus on their messages, at the cost of fleshing out characters and developing other dramatic aspects like plot progression. This latter technique concerns how events unfold, how they are sequenced and paced. Some of the authors do not select events and encounters that are most needed to move the story from one point to the next. They lack that most needed fast-paced action and suspense to hold readers' attention. Some of their events are not motivated at all.

Though Buzani kubawo's (1958) symbolism is commendable, there is a conspicuous deficiency in the structure of the drama. Mmango, in her uDike noCikizwa (1963) sometimes forgets her characters. Characters like Dike and Cikizwa for instance never meet. They communicate by letter and yet they always confess their love for each other.

Inene nasi isibhozo's (1965) plot structure is not that bad because at least some of the events are well recorded. One notes an improvement in plot structure with the passing of these periods.

Plot progression is not bad in the drama of the second period (1973 - 1982). In some dramas of this period, like Ubusuku obungenanyanga (1973) by D.M. Jongilanga, events do unfold in a skilful manner and the author's plot is launched by conflicts, which occur to 
build excitement. Nevertheless, some of his characters are a bit larger than life and exaggerated for dramatic effects as already been highlighted in the chapter on the analysis of dramas' plot structure.

In Amaza (1974) the plot structure does have flaws. There are events, which are not well orchestrated. Certain events cause confusion and they do not even have an impact in the plot's development. This drama has strengths and weaknesses. The portrayal of the coexistence of two cultures for instance, is commendable. Some incidents are not motivated. This is explained in the evaluation of the drama's plot structure.

Mtywaku's drama has a very poor structure. This is caused by his unskilled portrayal of change in tradition as discussed in the plot analysis of plot structure.

\subsubsection{Theme}

Dramas of the three periods under study have common themes. The cultural pattern of male domination persists in all the three periods: Men are portrayed as adults who are allowed to make decisions about women. In the first period, 1958 - 1965, noted themes are forced marriages and women abuse. So is the case in the dramas of the second period, $1973-1982$.

In some of the dramas of the third period, one realizes that power over women exists because women have not redefined their roles in the emerging social order. For a long time, women have accepted passively their lot in life. In her drama, linkunzi ezimbini, Mothlabane suggests that it is now time for women as Ngemeka (1988:458) puts it "to cease being willing victims and grab the power which was illegally taken from them and used to keep them in a servile state". Common themes during this period are women abuse. Women characters of this period are still struggling for rights and some men are still opposing them. This opposition does prevent some women characters from attaining their goals. One cannot help but wonder why Nolasti in linkunzi ezimbini starts by being aggressive in pursuing her rights and then later on loses the battle and decides to beg her husband who abused her to accept her back. What one realizes is that abused wives usually return to their husbands for a range of complex psychological reasons. For example, hope for better feelings of responsibility, husband's moods, fear of a worse 
future, belief that the abuse, although horrible, is just a part of "normal" life. There is also fear for the children.

\subsubsection{Evaluation of dramas}

Literature that offers role models, as these dramas under study do, should raise individual consciousness by linking literature to life. The act of reading in this fundamental outlook of literature is seen as a communication between the "real" life experience of the author and the reader. The issues authors raise should be drawn from the life experiences of the readers. Their characters then are true in as far as they speak out current and real life issues.

Dramas under study for these three periods force themes, which affect their plot structures because at times they completely forget about their characters. Their themes are similar in that they all are concerned with injustices against women. Conflicts are vividly portrayed. The third period took these themes and conflicts further. The authors who explore these themes of injustices against women seem to moralize the reader to the degree that in some dramas the moral lesson amounts to a full sermon. This is one of the reasons why dramas under study during these various three periods are often said to be of poor literary value.

Commenting on this literary failure, Gerard (1980:58) observes:

After all, it seems natural that the status granted to the vernaculars in socalled "Bantu" education in the early fifties should have ambiguous results: it has created a huge potential audience and turned vernacular writing into a profitable commercial proposition. On the one hand, this audience is primarily one of school children and this, together with the demands of censorship, is certainly not conducive to mature writing dealing responsibly with the real problems of the social structure.

Some of the dramas of the third period are characterized by the problems of a changing society in which new cultural elements should be incorporated or replaced the old ones. Authors delve into moral issues for new changes. One would realize that the dramas of the three periods exploit to a greater degree the traditional senses the modern oppositions 
and some authors seem to favour both. The themes of injustices against women become so common to the extent that they seem expedient.

The issue of culture seems to be diminishing, though here and there culture enthusiasts try to prove that certain cultural patterns of certain periods are or were the best, and we should turn the clock back. Most authors like Mothlabane and Mmango propagate change. One wonders if the debate on culture and customs is not long outdated and should be forgotten. One also wonders if culture is static and whether it should remain what it was ten decades ago. 


\section{CHAPTER 5}

\section{THE WOMAN AS A CHARACTER IN THE XHOSA DRAMAS}

\section{$5.1 \quad$ AIM}

The aim of this chapter is to examine the portrayal of the main woman character in the dramas of the three periods under study. Other characters will also be invariably included because it is these other characters that bring out qualities or distinctive features in the women characters under consideration. The characters' growth or change will be explored. This entails an analysis of the characters' early traits and how these change or develop.

Certain key incidents that may stand out, along with objects closely associated with the character will be analyzed together with several key quotations spoken by the character or by someone else in the dramas.

Before women characters are discussed, in each and every drama under study, the main story line of the dramas will be extracted.

\subsection{THE DRAMAS IN THE FIRST PERIOD}

\subsubsection{NomaMpondomise (in W.K. Tamsanqa's Buzani kubawo)}

NomaMpondomise and Gugulethu are in love. Gugulethu has already proposed marriage to NomaMpondomise, but unfortunately his parents want him to marry Thobeka against his will. While NomaMpondomise accepts his proposal by letter, she indicates that she has a problem of the lobola cattle, which are already paid for her by Mcunukelwa. NomaMpondomise informs Gugulethu in the letter that because she knows what love is she has decided to drive away Mcunukelwa's cattle. She tells him about her resulting unhappiness.

In her act of driving out cattle, NomaMpondomise does not follow the custom because Mcunukelwa's cattle are supposed to be replaced by Gugulethu's. Sadly this does not happen. This is an artistically discreet way of symbolizing that NomaMpondomise and Gugulethu's marriage will not take place. 
NomaMpondomise reads in the 'Imvo zabaNtsundu about Mzamo's murder and Gugulethu's marriage. Sirayi (1993:68) suggests that Mzamo's murder is a subtle manipulation by the playwright of announcing to Gugulethu's lover, NomaMpondomise, that Gugulethu has married another woman. One cannot help but share this observation. This results in NomaMpondomise's heartbreak and she cries out:

$\begin{array}{ll}\text { NomaMpondomise: } & \begin{array}{l}\text { Bawo-o! Bawo-o! } \\ \text { Bawo ndixolele! } \\ \text { Ndixolele-e-e! }\end{array} \\ \text { NomaMpondomise: } & \text { Father! Father! } \\ & \begin{array}{l}\text { Father forgive me! } \\ \text { Forgive me! }\end{array}\end{array}$

Indima 5, Umboniso 1:76

Act 5 , Scene 1:76

NomaMpondomise asks for forgiveness from her father because he is the one who cursed her when she decided to go on with the act of driving out Mcunukelwa's cattle. In African culture, there is a belief that if one's parents or any elderly person tells one to go her own way, then misfortune falls on that person. Langeni, NomaMpondomise's father, even went to the extent of saying to his daughter that she will remember his words one day.

NomaMpondomise decides to take Gugulethu to court for the breach of promise to marry her. Charges are laid against Gugulethu. He is found guilty and Zwilakhe takes it upon himself to pay the fine. NomaMpondomise and Gugulethu kiss each other and then she goes away to drown herself. Her mother also dies upon hearing this news:

\author{
uMaNyawuza: Yho-o-o! Umntan'am! \\ Umntanam Kazi ndingumntu oyintoni na bantu bakwa- \\ Nyawuza! Ndincedeni ngomntan'am! Yho-o-o! \\ (Uyagibiseleka uyafa)
}

Indima 5, Umboniso 2:82 
MaNyawuza: $\quad$ O! O! My child!

My child! What kind of a person will I be people of Nyawuza clan? Help me with my child. O! O!

(She collapses and dies)

Act 5 , Scene 2:82

In response to the question: who should your characters be, Brooke (1995:65) suggests:

Characters must be people your audience will be attracted to immediately. They may be a little bit larger than life and slightly exaggerated for dramatic effect.

In Buzani kubawo, NomaMpondomise is a very poorly portrayed character because of the author's deliberate attempt to focus the attention on the issue of forced marriages. Her portrayal is exaggerated for dramatic effect. One draws many unmotivated actions perpetrated by NomaMpondomise. It is strange that she decides to drive away Mcunukelwa's lobola cattle because of Gugulethu's marriage proposal by letter. They do not even meet. They last met in the wedding ceremony, which they both attended. They confess their love for each other in the poetic language they use in the letters. NomaMpondomise commits herself to Gugulethu:

uNomaMpondomise: $\quad$ Mna ndingowakho, andiboni wumbi.

Indima 2, Umboniso 4:29

NomaMpondomise: I I l $\quad$ am yours, I see no one else.

Act 2, Scene 4:29

In confessing her love for Gugulethu, NomaMpondomise uses few, but telling words. Some of the problems of the two characters are contained in their letters, which they wrote to each other, as the contents hide their feelings for each other.

NomaMpondomise's driving away of lobola cattle does not make sense at all because there is no evidence of any deep love relationship between her and Gugulethu except for the letters. The author is so pre-occupied by the theme of forced marriages that in the process he forgets to bring these two characters together. If NomaMpondomise and Gugulethu are seriously in love with each other, how could she not know about 
Gugulethu's marriage? When last did they meet? Why are they not communicating with each other just like people who are about to get married?

In dramatic character portrayal, characters must be recognizable and be familiar to the audience. NomaMpondomise is not interesting enough to generate strong emotional reactions because she is not real to the audience. NomaMpondomise's character portrayal is completely at the expense of the plot structure. As a result, the play has no balance at all. In order to inform NomaMpondomise about Gugulethu's marriage, the author decides to kill Mzamo as they are busy preparing for Gugulethu's wedding. What a coincidence.

The author forgets that in plays of a tragic type where momentous actions are concerned, the demands in the way of motivation are very high. Readers often refuse to take seriously a supposedly tense or serious drama in which life-threatening action is inadequately motivated. Rae (1971:59) explains that "such a negligence of psychological plausibility turns tragedy into travesty".

\subsubsection{Cikizwa (in A.M. Mmango's uDike noCikizwa)}

In uDike noCikizwa by contrast, one identifies various tragic events, which lead to death. As Jafta (1996:107) puts it, "we take the characteristic traits that we get from the focalization of the writer on the action of the character and on what he says." These traits, she elaborates, are taken and linked up with the intention of the writer.

Dike and Cikizwa are children of modern times, not of darkness. Cikizwa is fiercely in love with Dike. In their letters, they are always professing their love for each other in contradiction to the planned forced marriage for Cikizwa. Their deep feelings for each other are inevitably exposed in their letters and clearly they intend to marry only because of love.

Cikizwa is a suffering character and one cannot help but empathize with her because she does not deserve it. She decides to follow her heart by fighting for her love, Dike. The suffering of Cikizwa is used as an early point-of-attack as well as a means of opening one's eyes to future events. Sando, Cikizwa's father, decides to force Cikizwa to marry Mjongwa. Having observed the type of traditional relationships between parents and their 
children one does expect a disastrous end. Cikizwa decides to obey her father because then she will be blessed.

Cikizwa's suffering is strengthened because she becomes ill and lean with no thought, knowledge or understanding. She decides to keep on pretending to be ill. Nonjoli befriends Cikizwa for her own selfish needs. Cikizwa's friend, Nonjoli attempts to murder her because she wants to get to Mjongwa and Cikizwa is a stumbling block.

Eventually, Cikizwa revolts in church. She refuses to marry because of the absence of love and she also revolts against her father. Sadly, her revolt is too late because she only hears in church that her love, Dike, is murdered. Cikizwa then, commits suicide.

One can clearly see through his characters that the author's intention is to show the restrictive nature and injustice of traditionalism to women.

Cikizwa is a weak character. At first, one is given the impression that she can stand up, think and reason as depicted in her dialogue with her aunt. She talks about gifts that one is endowed with - gifts like to think, to know, to reason and to understand, to love. Sadly, she does not use these gifts in convincing her father about dangers of forced marriages. She obeys her father's laws. She even goes to the extent of regarding it her obligation to obey them. She says to Nonjoli:

Cikizwa: ...ndicing'ukuba ukuthobel'umthetho wabazali yinyaniso

Indima I, Umboniso 5:10

Cikizwa: I think that it is the truth that we should obey our parents.

Act I, Scene 5:10

Cikizwa is dependent on Dike hence she pretends to be ill until Dike responds to her letter. She has no plan at all to thwart her father's actions. One shares the views of Jafta (1996:111) when she suggests that it is because of this weakness that Cikizwa falls prey to Nonjoli who is interested in Mjongwa, Cikizwa's husband-to-be. Cikizwa does not take the initiative, just like Feziwe of $\underline{\mathrm{uFeziwe}}$ okanye inkohlakalo by Mtywaku.

Jafta explains that a tragic error changes events in the play dramatically when Cikizwa's plans are revealed to Sando. 
Cikizwa summons courage only in church where she challenges her father's authority at last. She does not bother herself anymore about her father's response to her actions. She is bold because she thinks that Dike is still alive and when her father breaks the news of his death, she demonstrates signs of weakness and dependence and decides to commit suicide.

One shares the view of Jafta (1996:101) when she explains that Cikizwa, though a weak character, is a tragic character. Furthermore, she says, "she is a victim of circumstances but she exercises her choice in dying for the ideas she cherishes". Cikizwa is destroyed by the path she has chosen for herself. She chooses not to submit to traditional law, which forces her to marry Mjongwa.

Dike is killed by Sando who shoots him at point blank range. The two characters, Dike and Cikizwa believe that they shall meet in paradise where they hope to enjoy their love. Though Dike and Cikizwa have lost their battle in this world, they win beyond the grave. Jafta (1996:170) explains that their death has brought new thinking though they struggled and suffered for it. She asserts that:

... this is the essence of tragedy where the greatest of characters is seen beyond their own doom.

Mmango's play demonstrates that the tragic in Xhosa is expressed and seen through the worldview of the people, as suggested by Jafta (1996:388). Furthermore, she says "it is greatly influenced by culture of the people in how they see the pain that destroys their very existence."

Dike and Cikizwa's predicament has demonstrated that a public outcry for the satisfaction of individual ideals at the expense of the group creates divisions and hostility that undermine the cherished values. Jafta (1996:388) explains that:

The family is taken as the milieu of this tragic division because it is where the cracks first appear and where the children are pitted against their parents.

She further elaborates by saying that "the conflict arises out of the dynamism of culture and gives rise to a transition that cannot be avoided." 
The characters are so committed to their ideals that they do not want to change until they reach a breaking point and end disastrously. They arouse feelings of pity and fear. One cannot help but empathize with Cikizwa who is so committed to her ideals that she becomes rigid and then ends disastrously.

Mmango's play uDike noCikizwa is characterized by conflict, character and feeling and these are said to be the most important elements of the tragedy in Xhosa.

\subsubsection{MaSukude (in A. Mtingane's Inene nasi isibhozo)}

MaSukude is the protagonist in this drama. She suffers severe distress because Lolo and his wife MaDlamini dominate her. After the death of MaSukude's husband, Njinge, Lolo is appointed by Mfolo, Njinge's brother to act as an overseer on MaSukude's household. The power of the overseer ,Lolo, has no limits because he controls virtually everything and MaSukude feels like a stranger in her household. She suffers severely and channels her anger to her relatives' children with whom she lives. MaSukude's ill treatment results in unnecessary fights with MaZulu and MaDlamini whom she accuses of interfering with her domestic affairs.

MaSukude is depicted as a strong character who does not like to be dominated. She is very aggressive because she feels that she is oppressed as a result of her being a widow. She feels marginalised. MaSukude attacks tradition and custom blatantly and expresses her disapproval of certain glaring abuses of tradition which impede progress. She encourages her son Vuma to have a sense of responsibility and to take care of her household because he is a man. She reminds Vuma as follows:

MaSukude: Uyaqonda ukuba uyindoda?

MaSukude: Do you understand that you are a man?

Vuma: $\quad$ Ewe ndiyaqonda, mama.

Vuma: $\quad$ Yes mother, I understand

MaSukude: Uyiqonda phofu yona into yokuba nguw'umnini walo mzi?

MaSukude: Do you understand that you are the owner of this homestead? 
Vuma: $\quad$ Ndiyayiqonda loo nto mama.

Vuma: I do understand that mother.

MaSukude: Mntwan'am ndikhathazwa nguyihl'omncinci. Okoko kwathi kwabhubh'uyihlo lo mzi uLolo uwenz'owakhe. Makaphume aphele kulo mzi, uLolo noMaDlamini wakhe abananto yabo ilapha.

MaSukude: My child, I am worried by your uncle. Since your father died, he must be made to leave this home, Lolo and MaDlamini have nothing of theirs here!

Indima I, Umboniso 4:12 Act I Scene 4:12

When MaSukude is engaged in a fight with MaZulu and MaDlamini, she feels that they trust their husbands so that is why she reminds Vuma that he is a man in her household. Her next step is to encourage Vuma to get married. When MaSukude decides that Vuma should marry so that he can become their heir, her aim is to replace Lolo as head of the family with someone she trusts. This therefore is the beginning of the reversal of her fortune.

Reversal is one of the elements of tragedy. Other elements worth mentioning are solemnity of action, discovery, hamartia and hubris. According to Aristotle (1965:47) reversal is a change from one state of affairs to its opposite.

Fowler and Fowler (1995:1180) share the above definition when they observe reversal as:

The opposite or contrary, the contrary of the usual manner, an occurrence of misfortune, a disaster especially a defeat in battle.

From the onset, MaSukude is portrayed as a suffering character that is depicted by her inlaws as a cruel stepmother. Her husband Njinge is dead and, in addition to a son by the name of Vuma, she has another son, Themba, who is the son of her husband from a previous marriage. She is objectified and denied a voice in her household affairs. Mfolo, who is traditionally the head of all in Njinge's homestead, instructs Lolo to control 
MaSukude's homestead. This decision is finalized without MaSukude's involvement. She is not consulted. Mfolo clings to the traditional roles. He says:

Mfolo: Nanku uLolo umninawa kaNjinge oliliso lomzi. Ukuba kukho
into ekuxakileyo okanye ongayithandiyo yibike kuye
nibonisane ngayo nobabini

Indima I, Umboniso 1:7

Mfolo: $\quad H e r e$ is Lolo, Njinge's younger brother who is the overseer of this homestead. If you have any problem or something you do not like, report to him so that you may discuss it together.

Act I, Scene I:7

MaSukude is forced to conform to traditional laws and this ill treatment sows seeds of protest, defiance and hatred. The seeds of cruelty germinate in the fertile soil of MaSukude's broken heart. When she resists these oppressive traditional laws, her in-laws see her as a misbehaving woman. One of the social duties of the wife is to conduct herself with utmost dignity. A wife in African culture is expected neither to be quarrelsome nor to disturb peaceful relations. MaSukude is accused of not being exemplary. She is said to be different from the other well behaving women:

Mfolo: $\quad$... Qweba isimilo ke njengawo onke amakhosikazi andilekileyo

Indima I, Umboniso I:9

Mfolo: $\quad$... Behave yourself like all other dignified women.

Act I, Scene 1:9

MaSukude's in-laws believe that resistance offered by MaSukude needs to be dealt with by men only, because men are naturally and traditionally dominant.

MaSukude informs Lolo about Vuma who is supposed to get married. Lolo reminds her about the tradition that Themba must marry first because he is the eldest. MaSukude argues that Vuma has been looking after the homestead and that is a sign of responsibility. Vuma therefore must be given first preference. MaSukude embarks on a 
violent protest against Lolo. She tells him of her determination through thick and thin to prevent the proposed marriage:

\section{MaSukude: Inene nasi isibhozo! Akunakuze kuzekelwe itshiph'elaggiba ishumi leminyaka eKapa ekh'uVuma umntu obelima egcine nezi nkomo.}

Indima I, Umboniso 7:21

MaSukude: Truly, I swear on my honour. It cannot be done that a useless person who spent fruitless years in Cape Town should get married first before Vuma who has been looking after the home.

Act I, Scene $7: 21$

MaSukude's in-laws, especially the men, look down upon her. Mfolo undermines MaSukude by making the following statement:

Mfolo: $\quad$ Lo ke umfazi uza kwaneka umcimbi womzi emadodeni uza kusanekela ngabuni?

Indima 2, Umboniso 1:24

Mfolo: $\quad$ This particular woman who you invite to come and lead men in this matter, what right does she have?

Act 2, Scene 1:24

To show that Mfolo oppresses and undermines MaSukude he does not even believe that she can negotiate and argue. To him, being a woman entails powerlessness, that is why he argues as follows:

Mfolo: $\quad$ Bubufazi ke obo ubuthethayo. Thina sithetha ngesiko

Indima 2, Umboniso 1:24

Mfolo: That is womanish talk. We are speaking about custom. 
Mfolo further reminds MaSukude that she is supposed to be in charge of domestic chores:

Mfolo: lyabukeleka ke kakhulu intobeko oyenzileyo namhlanje, ukuba uthi xa kukho nto ithile ikuxakileyo, ukhumbule ukuba kukho iintloko ezingamanqekele zomzi wakho ezinokuthi ukuba zidibene ngamacala ebunzi zinamulule neliqhinwe nguthikoloshe iqhina, zinamulule neyenabulele inqanqanqa.

Indima 2, Umboniso 4:36

Mfolo: $\quad$ Your respect is desired today that you should approach the wise men of your homestead, men who are capable of solving the most difficult problems, when they come together (as men).

Act 2, Scene 4:36

Unfortunately for MaSukude, Themba arrives foiling her plans. She asks for a plan from her friend No-ayini who advises her to remove the stumbling block, Themba. She gets the poison from No-ayini because she herself cannot come to a decision. MaSukude does not do the poisoning of Themba herself. She is irresolute because she has suffered a lot. She uses children to poison Themba's food on the day of his marriage. MaSukude panics when it becomes clear that she will be found out. Again acting on advice from No-ayini, her friend, she tries to instruct Nosisa to poison Lolo. Because she intimidates the child, the food is mistakenly served to Vuma. MaSukude is surely an irresolute character because she does not do all this poisoning herself.

MaSukude eventually goes mad and hangs herself. Unfortunately her fight for her suffrage leads to serious offences. She causes unnecessary waste of human life: Lolo, Themba, Vuma, Vuyiswa and MaSukude.

Mfolo influences the reversal of MaSukude's fortunes as well. Mfolo wants to follow the accepted custom and eventually he causes MaSukude's downfall. Mfolo does regret his stubbornness at the end of the play. He wishes that he had forced MaSukude to follow the custom. He says that if he had known that the consequences of his stubbornness would be this bad, then he would have refrained from forcing her to do things against her will. He is worried about so many unnecessary deaths. 
Mfolo: Akwaba ndandingamnyanzelanga! Bendiba ndiyamgoba lo mfazi, kanti nay'undibona iinkani. Bendingazi kanti sakuba nje isiphumo nesiqhamo sale nto. Bendingazi - Bendingazi-

Indima 4, Umboniso 2:70

Mfolo: How I wish I did not force her! I thought I was disciplining this woman, only to find that she sees me also as a stubborn person. I did not know that the result and fruit of this thing would be like this. I did not know - I did not know -

Act 4, Scene 2:70

One could be tempted to conclude that Mtingane's drama like other dramas under study is nothing but a plea against women's unjust treatment. His central preoccupation in this drama is an outright attack on women's injustices. He does not attack tradition and custom blatantly, but he expresses his disapproval of certain glaring abuses of tradition.

In the end as one seeks to argue, Mtingane in the portrayal of MaSukude as Ogude (1999:76) puts it, still upholds a character typology which invites allegorical reading of characters as symbolic structures that stand for something larger than themselves. In the delineation of this character, MaSukude, as the main victim of gender oppression there is a lot of repetition as well as exaggeration of oppressive gender incidents. Almost every incident concerning MaSukude for instance, is securely linked in a causal chain that compels the readers' attention to gender oppression. This is evident in the above discussion. From the very beginning of the play, the author focuses on MaSukude as a victim of gender oppression. MaSukude's bad behaviour is made prominent to such an extent that she can be classified as an allegorical figure. Her existence is symbolic.

\subsubsection{Conclusion}

In this section on conclusions, attention will be focused on the comparison of the women characters in this specific period. Those women characters are NomaMpondomise in Buzani kubawo, Cikizwa in uDike noCikizwa as well as MaSukude in Inene nasi isibhozo. The section examines the development and the portrayal of women characters within the structuralist view of characterization. According to Perrin (1988:69) a successful 
author is the one whose characters are portrayed fully enough to justify their roles in the story and make them convincing.

When comparing the three women characters cited above, one wishes to assert that they have common features. As has been observed in this study, these dramatists are grappling with the problem of documenting women's position as victims of their culturally constructed subordinate status, then in the process they portray women characters that suffer a lot. They are portrayed poorly, for instance, in Buzani kubawo, NomaMpondomise is a very poor character, most of her actions being unmotivated. So is the case with Cikizwa in uDike noCikizwa. Cikizwa is a weak character although one at first thinks that she is strong and can stand on her own. Another common feature in these characters is that of committing suicide when they are unable to achieve their goals.

MaSukude in Inene nasi isibhozo is different from the other two characters in the sense that she is depicted as a strong character. She stands up for her rights in a very aggressive manner. She is different from the other two women characters because she is not afraid to challenge those who stand in her way by laying oppressive cultural laws. Unfortunately, MaSukude's fight for her rights leads to criminal offences and she also commits suicide.

The manner in which the women characters of this period are portrayed by the three dramatists is a deliberate attempt to focus the attention on the issue of injustices against women. Their distortion of culture and character portrayal is double layered: They not only voice their points of view on women, but also depict African culture. In the process, they portray characters that are images of mankind. Their existence is symbolic. They are larger than life thus assuming allegorical status. This is because of thematic concerns. The above-cited weaknesses in character portrayal are evident in all the dramas under study during the first period (1958-1965).

\subsection{THE DRAMAS IN THE SECOND PERIOD}

\subsubsection{Novayithi (in P.M. Jongilanga's Ubusuku obungenanyanga)}

Novayithi is the protagonist in this drama. She suffers a lot. She is abused by her husband Solani who treats her like dirt and even by her women neighbours who give her names because she is always begging for food and yet Solani is enjoying himself in the 
location humiliating Novayithi. Novayithi continues giving birth to children yet she struggles to make ends meet. Nomakhephu says:

Nomakhephu: Uzenza ngabom, kukh'umntu ongasoloko esefukwini mihla le
ibe indoda ilibele kukuba ngungqikana kule lali.

Indima I, Umboniso 1:2

Nomakhephu: It is a problem of your own making, could there be someone who always gives birth to children while a man/husband loiters in this village.

Act I, Scene 1:2

Dengana, Novayithi's son, murders one of her neighbour's sons. Solani blames Novayithi for this. He does not stand by her treating her as if this son is hers alone. A reduction of Novayithi to the status of a "mindless" adult is always apparent in Solani's dialogue. Whenever she challenges Solani's authority in the house, Novayithi is chastened by her husband. This is evident in the following dialogue:

Novayithi: Buyintoni ubudoda bakho?

Novayithi: What about your manhood?

Solani: Sukugeza man! Yonke le nto kukungakwazi kwakho ukuqeqesha, uhlala naba bantwana mihla le kweli khaya.

Solani: Don't be silly man! You are to blame for all this because you do not know how to discipline children, you are the one who is always with these children in this home.

Indima I, Umboniso 5:20

Act I, Scene 5:20

In Jongilanga's drama there is also a subtext of the power struggle between men and women. Having realized that he has lost power, Solani resorts to physical abuse. It is clear that Solani represents patriarchal society. 
At first, Novayithi displays traits of being a weak character, but later on circumstances change her. Novayithi does not enjoy her married life at all. She is despised and neglected because even her neighbours run away from her:

MamCirha: Uthin'unyoko? Uthi nantsi intoni namhlanje?

MamCirha: What does your mother say? What is it that she says today?

MamCirha: Uzumxelele unyoko ukuba ipalafini kum yinto esemagqabini, nala ntwana ndinayo, ndincedwe nguNomakhephu lo aze akhe azame madlelo wambi kuba eli lindim liphanzile, uyeva?

MamCirha: Tell your mother that paraffin to me is luxury even the little one I have was given to me by Nomakhephu Your mother must try some other better places because my can is dry, do you understand?

Isiqendu 1:2

Chapter 1:2

This above passage clearly indicates Novayithi's humiliation, sufferings and hardships, because her husband is not supporting her.

The author portrays a character who is not life-like simply because he wants to use her as a symbol to demonstrate injustices against women.

In this drama, the antagonist is a man, Novayithi's husband. He is the cause of Novayithi's miseries up to the end of the drama. The following passage indicates that Solani is under the influence of traditional custom of male dominance in the society:

Solani: $\quad$...khawuyeke man ndikhe ndimbeke kwindawo yakhe

Solani $\quad .$. leave me alone man, so that I can put her in her place

Isiqendu 5:21

Chapter 5:21

In the above dialogue Solani is ready to abuse his wife physically. He thinks that being abused is what she deserves and moreover a man cannot argue or discuss issues with his wife. 
It is only towards the end of the drama that Novayithi decides not to allow her husband to do as he wishes and it is too late. She does not approve him coming with his girlfriend to her home. This comes as a surprise, because Novayithi all along is conditioned to a degree where she cannot feel that her humanity is violated. Her life reflects the oppression of women, especially those who are the traditionalists.

The way Novayithi solves her problem of Solani coming with a girlfriend to her home is unacceptable. She reacts in a very dangerous way by throwing hot water at them. It is because of her character traits that she does not succeed in her endeavours. Even in this drama, thematic concerns affect the plot structure and characterization. These two dramatic plot pillars are symbiotic.

\subsubsection{Namhla (in Z.S. Qangule's Amaza)}

Namhla is an adopted child with clear modern views. She does not believe that the community should arrange marriages. Her parents' belief that they should choose her marriage partner is not acceptable to her. She loves Lizo, but unfortunately she is forced to marry Sidima. Namhla gets so frustrated that she starts drinking liquor and smoking heavily. There is a drastic change in her behaviour.

Namhla becomes pregnant and she tells MaDlamini that she is not ashamed of her pregnancy. She boasts about her shield, Lizo and they elope thereafter.

MaDlamini: (Ekhomba isisu sikaNamla) Hlazo lini eli?

MaDlamini: (Pointing at Namhla's stomach) What disgrace is this?

Namhla: Soze ndibe manyonywana ngalo mntwana, Ulihlazo kuwe, uliqhayiya kum, kuni usisiqalekiso, kuthi ulithamsanqeliso.

Namhla: I will never be ashamed about this child. He is a disgrace to you he is a pride to me, to you he is a curse, to us he is a blessing.

MaDlamini: Na... Na... Namhla!

MaDlamini: $\mathrm{Na}$... Na... Namhla! 
Namhla: $\quad$ Lo mntwana sisithintelo seenjongo ezimbi, likhonkco lam noLizo, ngumchankcatho wenkululeko

Namhla: This child is a shield against bad motives. He is a chain for me and Lizo, he is a bridge to freedom.

Indima 3, Umboniso 2:54

Act 3, Scene 2:54

At the meeting of the Bhele clan it is demanded that Namhla must abort her unborn child. They also suggest the ukungena custom upon which the death of her "husband" is strongly rejected by Namhla:

Qebeyi: Namhla Bhelekazi

Sikubizela into eqhelekileyo. AmaCirha anqwenela ukuvusa Umyeni wakho ngomnye woonyana.

Qebeyi: $\quad$ Namhla Bhelekazi

We have called you for something common. The Cirha clan would like to make your husband live again through one of their sons.

Namhla: Uxolo, ndiyayala loo nto.

Namhla: Sorry, I do not accept that.

Mphurhu: Isiko lisiko, akuthandiswa wena.

Mphurhu: Tradition is tradition, we will not go according to your wishes.

Sixhaxha: Uze uthi uyikhabela kude le nto, ube usazi ukuba waphule isiko, ungcungcuthekisa iminyanya

Sixhaxha: Even if you throw that idea away, you must know that you are breaking the custom. You are hurting the ancestors. You are disturbing the peace of the ancestors.

Namhla: Bekuthiwe kuqalwa ngam ukubona isiko?

Namhla: Am I the first one to see the custom? 
The Bhele camp think that Namhla's behaviour is a result of the wrath of the ancestors and as the result they suggest the appeasement of ancestors which they think will bring good fortune to her. Unfortunately the appeasement of ancestors does not succeed and she only succeeds in getting to know her own mother, Malimakhwe.

Namhla is a victim who is made to suffer. She is subjected to punishment and abuse by her foster parents, Danile and his wife. She is an adopted child of Danile and MaDlamini. Her character disintegrates because of this suffering and she starts drinking and smoking. Her elopement with Lizo does not help; instead it brings her greater problems. She seems to be suffering because of the wrath of the ancestors. She sticks to her convictions in spite of the criticism and mockery that she receives. She does not achieve her goal because she does not end up marrying Lizo. She attains nothing for herself.

Namhla is portrayed as a weak character by the author. In so doing, the intention of the author is to focus on his major theme: the co-existence of cultures. In this process he neglected his characters and the successful denouement of the drama; dramatically, nothing has been attained. Once more, the main problem is thematic concerns.

\subsubsection{Feziwe (in Mtywaku's uFeziwe okanye inkohlakalo)}

In Mtywaku's drama, Feziwe is the main woman character. Feziwe will be analyzed according to the following signposts, keys or wedges to understanding her. Feziwe is portrayed as an innocent suffering victim who is suffering and subjected to:

\section{(a) Loss}

Feziwe's father passes away. As she is still mourning the death of her father, her mother's health deteriorates because of Kwedinana's ill treatment. Feziwe's mother, MamCirha can not accept her cattle taken by force by Kwedinana. Kwedinana persists in torturing them about Feziwe's planned abduction. MamCirha passes away, leaving Feziwe behind with Kwedinana's cruelty. The death of MamCirha leads to Kwedinana's control of Feziwe's home. He does not even give her time to mourn the death of her mother. She is devastated and her only comfort was Nomathamo, Kwedinana's daughter who is also suffering because of her friendship with Feziwe. 
(b) Punishment

Kwedinana and his wife abuse Feziwe. They despise her calling her bad names. They punish their daughter for befriending Feziwe. Kwedinana organizes people to abduct Feziwe, but unfortunately for them Feziwe is with Nomathamo and they fight the party off successfully. Kwedinana and his group are not discouraged. They kept on trying to frustrate Feziwe. Later on, they succeeded in abducting her to marry an old sickly man.

Feziwe's home is not well catered for by Kwedinana while she is in her umzi. Boys sleep in some of the houses. There are also goats in other houses. The home is in a terrible mess.

\section{(c) Defeat}

At first, Feziwe defends herself from the ukuthwala party. Nomathamo helps her. Later on, Kwedinana and the ukuthwala party broke the windows at Feziwe's home and this time they succeed in taking her by force. Sadly, she is then defeated. She is so frustrated that even her physical appearance is terrible. She is doing all the duties of a traditional wife like stamping mealies and grinding maize. Nomathamo cannot believe her eyes when she sees her during her visit. Feziwe does not even want to be seen by her lover Thandile. Nomathamo has this to say about Feziwe's physical appearance:

UNomathamo: (emanga) Sisi, nguwe lo unje, Dlomo? Yini utata, uya kuyithini inkohlakalo engaka? Ukohlwaya ngasono sini utata, Dlomo? (Balilelane)

Nomathamo: (hugging her) Sister, is it you who looks like this Dlomo? O no my father; what does he mean by this cruelty? What sin have you committed for my father to punish you this way Dlomo? (They cry for each other)

Ufeziwe: $\quad$ (esidaleni) Ndim lo, Noma. Kuyo yonke imihla yokuphila kwam andizange ndazi ukuba ubom buyakwazi ukuba nje ukuba krakra, Khangela iingalo zam, jonga izandla zam, zimaxolo leli litye. Uyazibona zona iinyawo. 
Feziwe: (after a long time) It's me Noma, In all my days I never knew that my life could be this bitter. Look at my arms. Look at my feet, they have scales from this stone. Do you see my feet?

Indima 2, Umboniso 6:30

Act 2, Scene 6:30

(d) Change

Change occurs in Feziwe's behaviour. During Nomathamo's visit to Feziwe at her umzi, Nomathamo suggests that they should tell her lover Thandile about her problem, but Feziwe refuses, citing her embarrassment by her terrible appearance. Furthermore, she explains, as a Xhosa woman she is supposed to be proud and not invite and entice a man:

UFeziwe: N N Nengentombi yomXhosa ezidlayo andinakho ukulikhweba isoka Indima I, Umboniso IV:37

Feziwe: ... as a proud Xhosa girl cannot invite a man

Act I, Scene IV:37

From the above extract, one sees change in Feziwe's behaviour. She changes from modern ideas back to traditional customs.

Feziwe changes her career as well. She is a teacher by profession but now she decides to become a nurse. She even changes her home and moves to Pietermaritzburg where she meets her lover Thandile by chance.

(e) Grief: death of Thandile

In Pietermaritzburg Feziwe accidentally encounters Thandile at the post office. Thandile has become a lawyer in Umtata. They become excited and hug each other. Later on Thandile proposes marriage to Feziwe. Feziwe's prayers are answered because now she is going to marry her lover. By this time, Fuzile her brother is back at home. She informs him about the marriage and together they make arrangements for the planned marriage of Feziwe and Thandile. Upon hearing the good news, Kwedinana is devastated because he is always after Feziwe's downfall. He and his wife hire assassins to kill Thandile on his 
way from Feziwe's home. Thandile is murdered. Feziwe's happiness is short lived: Devastated she decides to commit suicide because of grief.

Feziwe is a passive character. Something is always being done to her. She herself has little initiative and she can easily be manipulated. Kwedinana and Nowikithi treat her as they wish. She does absolutely nothing to protect herself. It is her brother Fuzile who fights for her as she is being ill-treated by Kwedinana and his family.

Feziwe is a tragic character. She experiences downfall from good fortune to bad. In tragic drama, this is called reversal of fortune.

Cohen (1973:200) observes that reversal of fortune is the downfall of a protagonist from good fortune to bad. This refers to his collapse from a position of eminence to a state of destruction, though not necessarily death. Reversal of fortune in this drama can be seen in the development of Feziwe. To prove that for one to fall, one must first rise, let us explore the following points about Feziwe:

a) Feziwe is educated and has a job and lover.

b) She lost her father and mother.

c) She is abused by her father's brother and ultimately forced to marry an old man after being abducted.

d) There is no assistance whatsoever from her lover, Thandile.

e) Her possible marriage with Thandile is foiled when Thandile is murdered.

f) Feziwe commits suicide.

The failure of the author to motivate his idea of killing even good characters makes the plot more tragic, because characters are seen as products of a plot.

Just like Mmango's uDike noCikizwa, Mtywaku overemphasizes injustices against women. Unfortunately he does this at the expense of his characters, events in the drama as well as plot structure. Mtywaku portrays Feziwe as a character who wants to free women from the injustices of traditionalism. As a tragic hero, Feziwe has a single objective. Her entire being is concentrated in one aim, one passion, one conflict and ultimate defeat and it is for this reason, as Jafta (1996:111)puts it, that the prime agent of tragedy is heroic. 
Looking carefully at Feziwe, one realizes that she does not exist at all, she only suffers. Evidence of her suffering is augmented by many unfavorable conditions in which she lives. She loses her father and immediately thereafter her mother also passes away unexpectedly. Things become worse because she is abused and despised by Kwedinana and his wife.

Kwedinana and his wife force Feziwe to marry against her will for their own needs. At first she does fight the ukuthwala party, but later on she is defeated because Kwedinana and his party succeed in forcing her to marry. Feziwe's defeat elevates her to tragic stature. That she suffers, suggests the powerlessness of women under stultifying customs and traditions. This also illustrates the author's general view about women's ill-treatment.

Feziwe leads a very painful life. She decides to change her career after the death of her "husband" and becomes a nurse. She leaves her home and gets a job in Pietermaritzburg. She meets her lover Thandile and she becomes happy just for a short period because Thandile is murdered as they are still preparing for their marriage. This is tragic. Feziwe does nothing bad to anyone. She is always experiencing bad things from the other characters like Kwedinana and his wife. She is a passive character.

\subsubsection{Conclusion}

Conclusions in this section pertain to the portrayal of the three women characters of the dramatists of this period. These characters are Novayithi, Namhla and Feziwe in Ubusuku obungenanyanga, Amaza and UFeziwe okanye inkohlakalo respectively.

There are similarities in the way these characters are portrayed. They are all suffering. Novayithi is suffering because she is abused by her husband Solani. Namhla in Amaza is also suffering because she is forced by her foster parents to marry someone she does not love. Novayithi is portrayed as a weak character who does not fight for her rights. It is only at the end of the drama when she is pushed too far by her husband who brings his girlfriend to their home that she decides to fight but unfortunately she overreacts so her problems are not solved.

Namhla's character traits are similar to those of Novayithi in the sense that she is portrayed also as a weak character. She is also subjected to punishment and abuse. The 
manner in which she solves her problems does not help her. For instance, her elopement with Lizo makes matters worse.

Feziwe is also made to suffer by the author like the other two women characters discussed above. She is very weak and passive. She does not take any initiative in her problems even if the other characters advise her. She resembles Novayithi of Ubusuku obungenanyanga who is constantly advised by other women not to allow Solani to abuse her, but she will not heed their advice. Feziwe is a tragic character because she experiences her downfall from good fortune to bad.

Through the technique of the portrayal of these characters just like those of the first period, the authors overemphasize injustices against women. Their female characters are portrayed as characters with a mission to free women from the injustices of traditionalism. In fact, Namhla's entire being is concentrated on freeing women from the injustices of traditionalism.

\subsection{THE DRAMAS IN THE THIRD PERIOD}

\subsubsection{Nolasti (in Mothlabane's linkunzi ezimbini)}

In linkunzi ezimbini, Nolasti, the protagonist, is an abused wife. Having explored her background, one realizes that she is abused in many ways. Nolasti finds herself in the middle of the division of gender roles which are complicated by the crossing of cultural allegiances in which as Daymond (1996:223) puts it: "The men draw support from the old world, the women take their cues from the new". Nolasti has modern views and she is educated. She is employed and helps financially in maintaining the household including the other two wives of her husband. The polygamous marriage, in which she is, is itself abusive. Her husband Sigqibo has the luxury of deciding whom to sleep with on any given nights. Nolasti's husband does not feel the burden of supporting many wives because his abused wife Nolasti helps him. She works in Mrs White's home to help her husband to make ends meet but Sigqibo is not grateful at all.

Nolasti becomes rebellious against men and their power in marriage. She believes that polygamy is oppressive to women, but at the same time it is actually empowering because in the process she learns how to be independent in the absence of her man. She helps 
even the other wives of her husband. She believes that she can have the freedom to explore her own potential.

Not all African women who are in polygamous marriages are powerless, exploited, downtrodden victims. Many of them like Nolasti are intelligent, highly educated and independent. Nolasti is not selfish at all. She wants to educate other women who are oppressed and submissive. It is clear that other women like Nolimithi are also dissatisfied with their men who are oppressive and do not want to accept change. The problem with the other women is that they are afraid to say their views openly. The defiant Nolasti is prepared to come to their rescue by speaking out, because she feels that women are spoken for, about and against, but have no voice themselves.

Nolasti and her friend Nolimithi express female resentment about their traditional positions. They valorize the patriarchally constructed feminine in order to dignify women and to elevate their given status. Women, she says, are always, wrongly accused of killing their husbands. Apparently Ntungo who was supported by Sigqibo, Nolasti's husband, said this about women at the funeral. Nolasti boasts about her stubbornness. She compares herself to the other two stupid submissive wives of her husband. She vows to give her husband a bit of her mind:

Nolasti: Ucinga ukuba mna ndifana nezaa zibhanxa zibini wazizeka
phambi kokuba ndifike kulaa mzi. Ndiza kumxelela iindaba
zakhe nants'imini. Ade athi sithi ababulala amadoda nje sefile
yena?

Indima 2, Umboniso 7:30

Nolasti: He thinks that I'm like these two fools he married before I came to that household. I'll give him a piece of my mind today. How could he say they are responsible for the death of men? Is he dead?

Act 2, Scene 7:30

At home, Nolasti confronts the other two wives of her husband about their submissiveness to Sigqibo. Their worry is their husband Sigqibo who will soon be coming home and needing coffee. Nolasti persuades them to rest because they are all tired since they 
attended a funeral. They refuse to rest because they feel obliged to fetch water in preparation for their husband's food. Nofinishi tells Nolasti that they respect their husband not because he is a god, but because he is a head of the family:

Nofinishi: $\quad$ Simhlonele thina uJwarha kuba uyityhontsi yeli khaya

Indima 2, Umboniso 8:33

Nofinishi: We respect Jwarha because he is head of this household.

Act 2, Scene 8:33

Nolasti is extremely defiant now. As head of the family and a man, Sigqibo demands coffee from Nolasti on his arrival from the funeral. Nolasti asks him to do it himself. Sigqibo becomes furious and heads straight for Nolasti who moves towards the door. From the above discussion one realizes that dominant males do not willingly relinquish their power or privilege.

At her workplace, Nolasti is requested by her employer to help with babysitting since the couple will be going out to a dance. Nolasti agrees without consulting her husband. She feels this overtime will help her and her family because she will earn extra money. Sigqibo is furious with Nolasti for not consulting with him about babysitting. He says:

Sibonda: Uvume njani Nolasti? Uyivuma njani into elolo hlobo
ungakhange ugqithe kum?

Indima 2, Umboniso 2:17

Headman: How did you agree Nolasti? How could you agree to such a thing without my permission?

Act 2, Scene 2:17

Nolasti is always at loggerheads with her husband. She once refused him meat because she was preparing to go to sleep. Nolasti does get discouraged at times in her effort of trying to support all the members of her family in various ways. She feels that she is hated by everyone at her home. She talks to herself: 
Nolasti: $\quad$ Ndizuza ntoni ke ngaloo mizamo ngaphandle kwentiyo kaSigqibo nabafazi bakhe?

Indima 2, Umboniso 3:19

Nolasti: What do I get for my efforts besides being hated by Sigqibo and his wives?

Act 2, Scene 3:19

Nolasti is hated by the other two wives because her behaviour makes Sigqibo violent. They do not believe that she is taking good care of them. Sigqibo is always violent because he does not want to be challenged by Nolasti because she is a woman. Sigqibo's common law wives believe that Nolasti is a troublemaker, because of her quarrels with her husband. Nofinishi says to Nolasti:

Nguwe owenza ukuba lo mfo asoloko elugcwabevu ngumsindo. Phambi kokuba ufike kulo mtyanti yayingekho yonke le milo, kodwa oko wafika ekhapha akukho xolo.

It is because of you that this man is always angry. Before you came to this home there was no disturbance like this, but ever since you came to this home there has been no peace.

Indima 2, Umboniso 3:20 Act 2, Scene 3:20

Nolasti and Sigqibo quarrel about so many things. Sigqibo does not want Nolasti to send their son Luvuyo to the school of her choice. He does not want to argue with Nolasti about that. He wants Luvuyo to study at Macubeni at Lady Frere to prevent him from copying the bad habits of students in the other schools. According to Nolasti, if Luvuyo does not attend school in Alice then he will be deprived of important life skills. Sigqibo threatens to force Nolasti out of her job because he believes that she is influenced by her employer.

Nolasti demands that her voice be heard in her household because of her contribution:

Nolasti: $\quad$ Ndodandini... ndivumele ukuba ndibe nelizwi kulo mzi, ngowam nam. 
Nolasti: $\quad$ You man... allow me to have a say in this home, because it is also mine.

Act 2, Scene 6:29

Nolasti is determined to send their son to the school of her choice for the benefit of the child. She does not want their child to suffer because of male dominance and women's oppression. She challenges Sigqibo to go ahead with his threats. On this particular day, Sigqibo was going to sleep at Nolasti's place but he decides to leave her because of the argument. One sympathizes with Nolasti who swallows her pride and begs Sigqibo not to leave her. It is clear that she misses him. She says:

Yhini wethu Sithandwa, ngoku besendizithembise ukuba uza kulala apha namhlanje.

O no my love, I have already promised myself that you will sleep here today.

Indima 2, Umboniso 7:30

Act 2, Scene 7:30

Sigqibo refuses to which Nolasti decides not to detain him anymore. Nolasti says:

Akunani hamba.

Indima 2, Umboniso 7:30

It does not matter. Go!

Act 2, Scene 7:30

Even though Nolasti is depicted as a strong character, she ultimately became submissive to her husband after being beaten by him. She becomes submissive because she does not get any support from her mother, MaGaba. MaGaba confronts her:

MaGaba: Kukangaphi ndikuxelela mntwan'am ukuba ayidalwanga into yokuba kukhonye linkunzi ezimbini ebuhlantini obunye?

Indima 5, Umboniso 3:64

MaGaba: For how long must I tell you, my child, that it is not natural that two bulls bellow in one kraal? 
Even Madoda, Nolasti's brother agrees with his mother. He believes that Sigqibo's actions are quite right because he has long been pushed too far by a woman. He believes that women must be submissive and accept men as heads of families. Many circumstances such as the above forced Nolasti to be submissive. Moreover, her submissiveness does not come as a surprise because even the title of the play, linkunzi ezimbini (Two bulls) already refers to this solution. However, it is regrettable because it does not fit with the exposition of the plot. Bad consequences were expected to befall Sigqibo.

\subsubsection{Nozinto (in Ngewu's Yeha-a mfazi obulala indoda)}

Nozinto, the protagonist is a tragic character who suffers a lot. Her friends highlight all her circumstances and character traits as well as features of her emotional and physical abuse by her husband.

\section{(a) The discussion of her friends in the car on the way to Nozinto's home}

Nozinto's friends Zodidi, Nozinga, Nconyiwe and Phalisa are on their way to Nozinto's home after she has phoned them to come at once. They are wondering what the problem could be. Nozinga suspects that Nozinto and Zamile have separated or divorced. It transpires from the dialogue of these women that Nozinto vowed never to divorce Zamile. Phalisa therefore suspects that Nozinto might have killed her husband. Zodidi does not believe that Nozinto can do such a bad thing even if she is brave.

From the discussion of these women we also learn that Nozinto once hired assassins to kill her husband. Unfortunately, so they say, the would-be assassins could not do it because Zamile was a well-known professional dancer. One of these women, Nconyiwe explains that Nozinto is a greedy woman because she knows very well that if Zamile dies then she can inherit so many things. We learn besides that Nozinto wants to live in suburbs and not in townships.

Nconyiwe informs her friends that Zamile has an extramarital affair. Zamile is in love with a certain girl and it is rumoured that he is going to marry her: 
Nconyiwe: Uyabona, ikho le ntombi uZamile athe phithi yiyo ekucacayo ukuba umfo lo unesithembu kunjalo nje kukho namahum-hum okuba uza kuyitshata.

Indima I, Umboniso 1:10

Nconyiwe: You see, there is this girl that Zamile is head over heels in love with and it is rumoured that he is going to marry her.

Act I, Scene 1:10

Nconyiwe believes that women can kill men because of jealousy. One of the characters, Phalisa explains to the group that Nozinto's marriage is irreparably on the rocks. Lonely Nozinto is deprived of her marriage rights as a wife because Zamile is always away from home attending dance ceremonies and practices, always in the company of a girl who is always wearing mini dresses. Nozinto, according to them is just like an ornament or furniture to beautify Zamile's home. Nozinga tells them that Nozinto is in love with a policeman and the other women feel that Zamile is to blame for that, because Nozinto wants to be happy as well. However, they feel also that Nozinto is wrong by doing as Zamile is doing. She must not drag herself through the mud just like Zamile.

Phalisa strongly believes that it is not correct to think that a man has a right to do as he wishes at a woman's expense. These women do not agree with each other at all. Zodidi feels that Nozinto married Zamile knowing that he is a professional dancer who will be traveling all over the world.

Furthermore, Zodidi feels that Zamile cannot tolerate a drunkard like Nozinto. Zodidi says:

Phalisa, uNozinto wamtshata uZamile emazi ukuba ungumntu womdaniso! Kutheni ngoku kwacaca ukuba lo mdaniso yinto yabumini? Uzamile angayinyamezela njani into yomfazi oselayo ekucacayo ukuba uya eba ngunontyintyi eli lixa yena engabufaki kowakhe umlomo?

Indima I, Umboniso l:4

Phalisa, Nozinto married Zamile knowing that he is a professional dancer! Now it seems as if this is a new thing? How can Zamile accept a wife who 
drinks and seemingly is becoming a worse drunkard day by day and yet he himself does not drink liquor?

Act I, Scene 1:4

(b) The discussion of her friends in the car on their way home

In Scene 3, we are introduced to Nozinto's friends on their way home. They decided to go to Zodidi's place to discuss Nozinto's problem because Zodidi is alone at her home.

Zodidi tells the other women that she feels Nozinto knows very well about her husband's murder and she is deeply involved. They also question the fact that Nozinto was never arrested on her first attempt at trying to kill her husband. Nconyiwe informs them that Nozinto's policeman boyfriend decided to investigate the case himself. That policeman even left with Nozinto for the whole weekend pretending to be interrogating her only to find that they were enjoying themselves in a certain hotel in Port Elizabeth. Nconyiwe blames Zamile for Nozinto's bad behaviour. Zamile pushes Nozinto too far. Of these women, Phalisa is Nozinto's best friend and as such the other women feel that Phalisa knows the truth. It is said that even Phalisa's husband died in the same way as Nozinto's. Phalisa is the one who has all the details of Nozinto and Zamile's ups and downs of their marriage.

Having identified Nozinto's suspicious behaviour, these women are sure that very soon Nozinto will be behind bars. Nozinga believes that Nozinto is one of these women who kill their husbands in order to get money from their insurance.

The conversation of these women on the way home goes like this:

Zodidi: Isisimanga, bafazi, into kaNozinto! Kukho izinto endizikhileyo ngoku ebethetha nam emnxebeni, nto ezo ezindenza ndifune ukuqiniseka ukuba uyawazi umcimbi wokudutyulwa kwendoda yakhe.

Nozinga: (Ethethela phezulu ebambelele esinqeni) Nithi anganaso isibindi esinjalo?

Zodidi: Ngeli xesha uNozinto ethetha nam umyeni wakhe ubegqitywa kudutyulwa. 
Nozinga: (Eqhwaba izandla) Yeha-a-a umfazi obulal'indoda!

Nconyiwe:Andifuni kodwa isisithele into yokuba uNozinto ade angcole ngolu hlobo nje wenziwe nguZamile lo.

Indima I, Umboniso 3:12)

Zodidi: Nozinto's circumstances are strange, women! I picked up a few things during our telephone conversation, and those things force me to be sure that she knows about circumstances around her husband's murder.

Nozinga: (Raising her voice and putting hand on her waist) Do you think she could have had the courage?

Zodidi: When Nozinto was talking to me, her husband had just been killed.

Nozinga: (clapping hands) Woe to the woman who kills her husband!

Nconyiwe:I do not want us to lose sight of the fact that Nozinto's devious character is caused by Zamile.

Act I, Scene 3:12

\section{(c) Discussion of Sipho with Phalisa, Khomba and Zodidi}

The author uses flashbacks extensively in the dialogue between them. After the discussion of these characters we know that Nozinto was at loggerheads with her neighbours. Nozinto was already prepared for her husband's funeral. For instance, she already had a black dress for mourning. We gather this from the discussion between Sipho and Phalisa. From the conversation of these characters we also learn that Nozinto did not even cry and Zamile was murdered at about 10:00 pm, but taken to hospital after $12: 00 \mathrm{pm}$. The conversation of these characters which is in the form of flashbacks runs thus:

Sipho: Ayinimangalisanga into yokuba athi lo mama edutyulelwe umyeni wakhe angakhali nokukhala? 
Sipho: Weren't you surprised that this woman did not even cry despite her husband's being shot?

Phalisa: Besingekho ke ukudutyulwa komyeni wakhe. Eyokukhala ke nokungakhali into asiyazi. Nokuba akakhalanga kaloku abantu abafani.

Phalisa: We were not here when her husband was shot. Whether she cried or not, we do not know. Even if she did not cry, people are not all the same.

Sipho: Ngokwengxelo yasesibhedelele uZamile ufike emva kwentsimbi yeshumi elinesibini. Yintoni le ilibazise kangaka ekubalekisene uZamile esibhedlele?

Ingaba yintoni le ebangele ukuba uZamile adutyulwe umfazi wakhe sele enayo ilokhwe yokuzila?

Sipho: According to the hospital report, Zamile arrived after 12:00 pm. What is it that delayed him to be taken to hospital? Why is it that by the time Zamile was shot, his wife already had a mourning dress?

Phalisa: (Esothuka) Eyiphi ke ilokhwe?

Phalisa: (shocked) Which dress?

Sipho: Laa lokhwe imnyama sifike iphaya phezu kwesitulo kwamnumzana uChaneka.

Sipho: The black dress that was on the chair at Mr Chaneka's home.

Indima 2, Umboniso 3:30

Act 2, Scene 3:30

Khomba informs Sipho that he could not go immediately to Zamile and Nozinto's place because they are not on good terms as neighbours. Sipho learns for the first time that there was once an attempt on Zamile's life. That case was never investigated. Zamile was reprimanded by being told to look well after his wife and thereafter Zamile was always under Nozinto's verbal abuse. Khomba did witness a few things on the night of the murder at Zamile's home. He did see the getaway car for assassins as well as one of the assassins. Though they are not in good terms with Nozinto he did go to her place when 
he heard gunshots. Nozinto did not want to communicate with him and simply banged the door in his face.

From the above discussion of these characters one therefore is positive that Nozinto is a suspect. The drama's technique reveals the simmering tension in Zamile's household. It is evident that they have long been sitting on a time bomb which could easily explode any minute. The vivid descriptions of Zamile's household by Khomba bring to life the alienating turmoil in this home. This technique is helpful and to the point in that it accurately describes Nozinto and Zamile's situation as well as the root of the problem. The author masks a powerful and explosive hostility of the characters. More importantly, this technique warns the reader about the imminent disaster. From Zodidi's explanations we gather that Nozinto has long been planning to do something about Zamile. Zodidi tells Sipho that Nozinto phoned her earlier on saying that she ultimately did that thing about which she once confided in her.

This technique has been used successfully by the author. It is clear after the discussion that Nozinto is the suspect and moreover there were circumstances beyond her control. Sipho's investigating skills are also demonstrated in these discussions. The exchange of views between these characters highlights not just Nozinto's character but also Zamile's betrayal. Almost throughout the drama, the segments presenting the plight of individual characters are set in flash backs by certain characters. Khomba gathers from Sipho, Nozinto's neighbour, that things were always bad between Nozinto and her husband. Nozinto once hired assassins to kill her husband. That attempt was not successful because one of them knew Zamile.

\section{The features of Nozinto through her own actions}

\section{(a) Nozinto's telephone conversation with Zodidi}

Nozinto's call to Zodidi demonstrates clearly that she is satisfied with what she has done and that she is glad it is over. Apparently she has long been planning this deed. She claims that she is free at last: 
Nozinto: $\quad$ Ndide ndayiqabelisa laa nto ndandikhe ndakuthela thsuphe yona. Ndikhululekile....

Indima I, Umboniso 1:1

Nozinto: At last I have finished that thing I once confided in you about. I am free....

Act I, Scene 1:1

Nozinto demonstrates bravery because she even calls Zodidi "gwalandini" (you coward). She even highlights that what she has done cannot be done by a passive person like Zodidi. Gleaning from what she says, Phalisa is her bosom friend and a pillar of her strength and as such Zodidi must come with her when coming to visit her.

\section{(b) Nozinto and Phalisa at her home}

In Scene 4, Nozinto and Phalisa discuss Zamile's murder. Nozinto is busy drinking wine. Nozinto shows Phalisa her funeral dress before talking about the unprofessional work of the assassins. From what Nozinto says to Phalisa it is evident that she is a murderer who does not feel guilty at all about Zamile's death. Nozinto shows Phalisa her funeral dress with certain dots. She goes to the extent of explaining what the dots symbolize. The black dots, she says, are a symbol of mourning just to deceive people at the funeral. The white dots are a hidden deep symbol of her freedom. Nozinto's actions depict a deep-seated cruelty.

One picks up signs of greed as well. She boasts about a beautiful dream house in Port Shepstone after Zamile's death. She is also not sure whether her policeman lover will share the idea of leaving his family and stay with her in the new house. To her, that is not a problem at all because she can always get another man. Nozinto has connections with drug dealers because one of the assassins is a drug dealer. She is cruel because she is not even prepared to bury Zamile in a decent manner by buying him a casket. Nozinto's character is demonstrated in the following dialogue:

Phalisa: (Eqobela uNozinto ilihlo) Ngawaphi la maxelegu awenze kakubi kangaka lo msebenzi? 
Phalisa: (Winking an eye at Nozinto) Who are these dirty people who did this work in such an unprofessional way?

Nozinto: Ndiza kukubalisela ngawo! Ndifuna kuqala ubone ilokhwe yomngcwabo endiyithungelwe ngusis' Nongxamile. UZamile akanakusinda tu. Into nje endinokukuxelela yona inye.

Nozinto: I will tell you about them! First, I want you to see the funeral dress designed by sister Nongxamile for me. Zamile cannot be saved at all. I can tell you one thing. The doctors can merely delay and defer his death.

Phalisa: Xa eswelekile laa mfo uza kuthenga umzi edolophini?

Phalisa: When that man dies, are you going to buy a house in town?

Nozinto: Ingathi ndiyazibona ndihlala eGcuwa! Ndiza kumka ndiyokutshona ePort Shepstone. Andazi ke ukuba eli lam ipolisa lakuvuma na ukushiya usapho Iwalo. Phofu akukho ngxaki kuba amadoda akhona naphaya ePort Shepstone.

Nozinto: I do not picture myself living in Butterworth! I will move to Port Shepstone. I wonder if my policeman will be willing to leave his family. In any case that is not a problem because there are many men even in Port Shepstone.

Indima I, Umboniso 4:20

Act I, Scene 4:20

(c) First interrogation and imprisonment of Nozinto

In the police cells in Butterworth, Nozinto becomes arrogant and it is clear that this is a defensive mechanism. Her explanation of circumstances on the day of the murder is very brief. Instead of phoning the police after her husband's murder, she phones her friends. Her explanation is that it is the first time for her to experience a problem of this nature and as such she did not know what to do. She is unable to answer most of the questions of the investigating officer. They have children and the children are away during the time of the murder. There is also a napkin, which she claims was pushed in her mouth thus 
blocking her cries. Even before Zamile's death, Nozinto is certain that Zamile is dead already. She says to Sipho, the investigating officer:

Nozinto: Kutheni ngathi ucinga ukuba ndinento yokwenza nokufa kukaZamile nje?

Indima 3, Umboniso 2:47

Nozinto: Why do you think that I am involved in Zamile's death?

Act 3, Scene 2:47

To Nozinto's greatest surprise, Sipho informs her that her husband is still alive:

Sipho (Ecaphuka): Mama, umyeni wakho akafanga....

Indima I, Umboniso 4:20.

Sipho: (angrily) Mother, your husband is not dead.....

Act I, Scene 4:20

(d) Nozinto and Phalisa before the funeral

Nozinto demonstrates clearly that she does not care about Zamile's death. She is excited because she is now rich. Already, she received money from Zamile's place of work. Phalisa is shocked that Nozinto has already claimed Zamile's money so soon. Nozinto explains that even before Zamile was murdered, Zamile's cheque was already with her. She is excited that she is still going to get a lot of money by the death of Zamile. She confronts Phalisa for not informing her that one is rich by having a man because when they die then widows become rich. Nozinto does not mourn at all instead she drinks a lot of wine.

From Nozinto's action one infers greed and cruelty. She does not even seriously think about their children who adore their father so much. She pokes fun at people who have come to support them on the loss of their loved one. In an act of transference, she remarks that they eat a lot of food at her home because they are greedy. She does not enjoy their presence. Her guilty conscience is dead because even if she killed Zamile out of anger and frustration but she ought to feel bad about the loss of life. She tries 
desperately not to feel the pain at all. She even quotes the words of a certain brave woman who experienced the same problem as hers: Lady MacBeth:

Here's the smell of the blood still; all the perfumes of Arabia will not sweeten this little hand. ... what's done cannot be undone.

Nozinto is not even sure when to show emotions on the day of the funeral. She does however worry about the reaction of Zamile's parents, especially his father who adores his son. Nozinto's cruelty is further depicted by her vow not to buy a tombstone for Zamile. She says that will happen over her dead body. Phalisa advises her to visit the witchdoctor because she is not safe and as such she can be imprisoned at any moment.

The discussion above is demonstrated in the dialogue between the two characters:

Phalisa: Kaloku ubuthe uZamile uza kumenzela ilitye.

Phalisa: By the way you said you will make a tombstone for Zamile.

Nozinto: UZamile uya kwenzelwa ilitye ndifile!

Nozinto: Zamile will have a tombstone over my dead body!

Phalisa: Ndinexhala ingathi baninzi abantu abayaziyo inxaxheba oyidlalileyo koku kufa kukaZamile.

Phalisa: I am worried because it seems as if many people are aware that you did play a role in Zamile's death.

Nozinto: Bangafane babe baninzi, mna andinamsebenzi naloo nto. Into abangenakuyenza kukumvusa uZamile efile nje, yaye efile nje ufile.

Nozinto: They can be many, I do not care. One thing they cannot do is to wake Zamile up, he is dead and that's it.

Phalisa: Ndisafuna, Nozinto siye kulaa mthandazeli nakweliya xhwele lam. Ndisuka andonwaba yaye ndinamanwele ngathi uza kubanjwa. Enye into endoyikisayo luhlobo olu uthetha ngalo ngathi akwehlanga nto. 
Phalisa: Nozinto I still want us to go to that spiritual and traditional healer of mine. I am not happy because I feel that you will be arrested. Another thing that frightens me is the way you speak as if nothing has happened.

Indima 2, Umboniso 1:46

Act 2, Scene 1:46

(e) Nozinto with Zamile's parents

Zamile's parents are shocked and devastated. All that Nozinto is interested in is the slaughtering of sheep. She explains that people will be coming from far places. She tells them that she has accepted Zamile's death and she is very strong and they should also be the same. She is totally against the eating of iinkobe (mealies). Lolwana reminds Nozinto about the African custom that women are not allowed to go to the graveyard if that person died by murder or accident. This, he says, is to make sure that women killers do not come near the graves of their victims. He says that he cannot even allow a woman priest to bury his son. Nozinto pretends to be mourning the death of her husband because she cries saying that she cannot afford to go to the grave of her husband. During this period, Nozinto drinks a lot. Empty bottles of liquor are even discovered by Zamile's parents in the cupboards and under the bed. All these actions show that Nozinto is guilty.

Nozinto in jail

She even thinks about committing suicide. She feels that she is the cause of her problems but at the same time Zamile is also to blame because he was abusing her.

Her frustration becomes worse when she is visited by her children who think that their father is in jail as well. What is strange is that she has no confidence in women as lawyers because her sister organized a lawyer for her. It is also brought to her attention that her house has been vandalized and everything is stolen without a trace. Nomaphelo explains that some waifs and strays have taken possession of the house. Nozinto's children do not attend school anymore, to save themselves from the sneers and slurs of other children, as Nomaphelo puts it. It is said that Nozinto's children are guilty by association. Nozinto is devastated and she blames herself as well. 
Nozinto says in her soliloquy:

...Kodwa indima endiyidlalileyo ekufeni kukaZamile icacile. Kazi esi silonda sakulibaleka na kubantu bakwaNtlangula! Kazi bakuze bandixolele na! NguMtyholi ebendichonge ngantoni lo? Ukuba bendingasililo igwala okanye ndinayo indlela yokuzixhoma ngendizibulala ndife fi.

Indima 3, Umboniso 5:62

...But the part I played in Zamile's death is clear. I wonder if this wound at the Ntlangula home will heal? I wonder if they will ever forgive me! Why did the devil pick on me? If I were not a coward or if I had another way of hanging myself, then I would do it and die.

Act 3, Scene 5:62

In all these episodes one may learn a lot about Nozinto through her own actions. Nozinto's actions portray different pictures about her. Her actions show that she is a cruel, brave and greedy character. It is as if Zamile abused someone who was cruel and greedy by nature. This is evident in some of her remarks. She confronts some of her friends for not telling her that one can be rich by killing a man. She is excited about Zamile's insurance policies.

Some of Nozinto's friends feel that her husband abused her and as such she had to kill him. They feel that her husband has long deprived her of her rights as a married wife. Zamile, her husband, it was rumoured even went to the extent of promising his girlfriend about marriage. Zamile spent a lot of time away from home and as the result Nozinto was always lonely. That is why she even decided to have an affair with a policeman.

\section{The gradual decline of Nozinto as a tragic character}

Nozinto, the protagonist is portrayed as a suffering character. Her husband has extramarital affairs. He is in love with another woman and it is rumoured that they will soon be getting married. Zamile is a professional dancer and he is always moving from one place to another with dancers. Nozinto is always on her own, and she is lonely. She decides to drink and to have love affairs as well. 
Some characters criticize Nozinto for her love affairs and drinking habits. They feel that as a woman she cannot do as men do. On the other hand there are those who sympathize with her. Nconyiwe is one of those characters. That Nozinto kills her husband are signs of her gradual decline as a tragic character.

Instead of calling the police on the night of her husband's murder, she phones her friends and boasts about her actions. She gets money from Zamile's work place even before the death of Zamile and she boasts about it. She buys a beautiful dress for the funeral even though she is not prepared to give her husband a descent burial. As if it is a feast, she even forgets the African custom that at the funeral of a murdered person there is no slaughtering at all. She decides to slaughter sheep until Zamile's father intervenes. She does not behave like someone who lost a loved one. She is always drunk and does not even care about Zamile's parents. She breaks all the African customs including the one prohibiting women from going to the graveyard of a murdered person. In the presence of her friends, Nozinto even practices to cry at the funeral. Nozinto takes a long time to report her husband's murder so that he can be taken to hospital because she wants him to die. This is what the investigating officer is questioning. At this stage she does not behave like a human being at all.

Although at first sympathy is shown with this abused character Nozinto, but ultimately she has to pay the price of all tragic characters. She ends up in jail because she is sentenced. She does not even enjoy Zamile's money because according to the law, a person who intentionally and unlawfully causes the death of the deceased is incapable of inheriting the estate of the deceased. She is said to be legally unworthy to inherit from the decedent. Some waifs and strays have taken possession of the house. Her children even do not attend school to save them from the sneers and slurs of other children. Even the court itself does not sympathize with her because of her cruel actions.

\subsubsection{No-ankile (in Mkonto's Emgxobhozweni)}

The protagonist in this drama is No-ankile. No-ankile is portrayed as a symbol to signify a variety of things. Her name meaning: a strong pillar, shows that she is a very strong character. No-ankile's treatment by Vakele does reflect the oppression of women in a way. Vakele does not involve her in the decisions of their home because she hates his daughter by his first wife. 
The way No-ankile solves her problems is unacceptable because she goes to her friends MaNdungwane and Nowam who destroy her in the process. Now and again from the heated arguments between Vakele and No-ankile, one realizes that No-ankile is not a symbol of African culture. She is not submissive and fights for her rights. She is portrayed as very evil character who orchestrates evil plans. If she wants to assassinate other characters she does that through letters with the help of her friends.

Sadly, she does not succeed and she ends up losing everything - her husband, her business and worst of all, her mind. She is portrayed as a greedy woman character. She is dangerous to herself and to the entire community of Alice. This brings chaos to the community. The above aspects are some of a number of tragic causes in this drama. Noankile suffers a lot.

In this drama, No-ankile is not an ordinary woman in society. She has a purpose in her life and a drive for power. She is very proud, one of Aristotle's recommendations is that a tragic hero must be a proud character. She changes from being proud to being arrogant making blunders in the process. This destroys her image and she becomes mad enough to be committed to the mental hospital. The author makes her not show any remorse for her deeds. Instead she still shouts about her businesses and her mayoral position. This is self-destruction.

No-ankile's boldness and initiative establish her as a powerful leader. No-ankile's strength, in fact, comes largely through speech, since she is powerless to change Vakele even though she explores many avenues in her devious plans.

\subsubsection{Nomhle (in Mcimeli's lintombi zinecebo)}

If one explores Nomhle's character, one observes that within the farce, she is a typical melodramatic character who progresses from rags to riches. As Schroyer (1970:34) puts it, this has a connotation of "too-mustiness". It is interpreted, Schroyer (1970:35) further observes, to mean that its action is flamboyant and its characters are stereotypes.

Nomhle is the protagonist. She is suffering because she is very poor and sad. Even her physical appearance is not good. She is in mourning over the loss of her parents and at the same time she is suffering severely under the yoke of her cruel brother Mvuzo. 
Nomhle has frequently been abused. Two lovers, Madoda and Vukile abused her and she rejects both because of their unfaithfulness. Unfortunately now she is pregnant, but undecided about the father of the baby and whom she loves. Mvuzo forces her to go along with his plans of getting damages from both men. She is made to promise to do everything that Mvuzo wants her to do.

Nomhle is devastated after payment of damages and proposals of marriage from both men after birth. Mvuzo always comes up with advice, which is very embarrassing to Nomhle. Firstly, Mvuzo advises her to refuse to see both of them and find another man. Secondly, to Nomhle's greatest surprise, she must follow her heart and take anyone. Thirdly, Mvuzo tells Nomhle to write a letter to both of them that she is now married and the child is with Mvuzo.

Nomhle cries frequently and is severely depressed to a point of suicide. At the organized meeting in the Noqaza forest, she is confronted by both men. She confronts Madoda whom she still loves but then she is ashamed when both men embrace her. Nomhle remains undecided about the two men and is even jealous of Vukile and Nomvuyo at the end where she breaks and cries bitterly. After Mvuzo's explanation of her unfaithfulness, Madoda accepts her but she only accepts him after he kissed her.

\subsubsection{Conclusion}

In the third period of dramas under study, the four characters under study are No-ankile of Mkonto's Emgxobhozweni, Nomhle in Mcimeli's lintombi zinecebo, Nolasti in Mothlabane's linkunzi ezimbini as well as Nozinto in Ngewu's Yeha-a mfazi obulala indoda. These characters do have common features.

No-ankile, Nozinto and Nolasti are portrayed as strong characters. They boldly fight for their rights but unfortunately they do not achieve their goals. Nomhle of lintombi zinecebo is portrayed as a weak character. Her brother abuses her but she is very submissive. Nevertheless at times she does fight against her brother's abuse towards her.

All four women characters cited about suffer a lot under male dominance. They fight desperately to free themselves from bondage of abuse. Unfortunately the tactics used by these women characters in shaking off the bondage of abuse lead to disastrous ends. In 
trying to fight for her rights as a married wife, Nozinto ends up killing her husband Zamile. She is imprisoned. Nolasti in linkunzi ezimbini does not succeed in changing her husband Sigqibo's abusive male dominance. She ends up persuading him to accept her back into their household. No-ankile in Emgxobhozweni fails dismally in her attempts to fight for her personal gains. She is portrayed as a greedy character who is after her husband's businesses. She is an evil character who orchestrates evil plans and she does not succeed. She looses everything.

Nomhle in Mcimeli's lintombi zinecebo is also suffering. Her brother abuses her by using her pregnancy predicament to enrich himself. She is the only woman character in this period whose problems are solved pleasantly at the end of the drama.

\subsection{SUMMARY}

\subsubsection{Conclusion with regard to the three periods}

These conclusions are concerned with the characterization of women with regard to the three periods. Playwrights of the first period $(1958$ - 1965) are so pre-occupied with didactic messages that they forget about their characters. Their works are characterized by injustices against women. Their characters are exaggerated and they are symbolic structures. MaSukude is a good example of such a character in Inene nasi isibhozo. NomaMpondomise is also poorly portrayed in Buzani kubawo. Even Cikizwa's portrayal in uDike noCikizwa is symbolic. The portrayal of these types of characters by authors is designed deliberately to expound a branch of their moral lessons. Injustice against women has become a prominent theme of this period at the expense of characterization. In contending this, one is not asserting that women are not oppressed.

Authors of the second period (1973 - 1983) also resort to the above-cited techniques in the portrayal of their women characters. Novayithi of Ubusuku obungenanyanga, Namhla of Amaza as well as Feziwe of uFeziwe okanye inkohlakalo are portrayed also as stereotypes with a lot of exaggeration. The authors' women characters are images of mankind. They are also larger than life thus assuming allegorical status. They uphold a character typology as Ogude (1999:76) puts it:

which invites allegorical reading of characters as symbolic structures that stand for something larger than themselves. 
Character portrayal of the third period does have weaknesses. Some of them like Ngewu's character Nozinto is well portrayed as a tragic character. The gradual decline of Nozinto in this drama Yeha-a mfazi obulala indoda as a tragic character is also noted and appreciated. Even during this period, features of these women characters are stereotyped attributes blended with the norms of action and values associated with them. Nolasti of linkunzi ezimbini and No-ankile of Emgxobhozweni are examples of those types of characters cited above. With the exception of Ngewu's Nozinto, women characters of this period just like characters of the first two periods under study, are portrayed as Zulu (1998:225) observes as "one of the pieces of the composition of the literary work."

\subsubsection{Conclusion with regard to the two themes of abuse and forced marriage}

Problems of women abuse or injustices against women as well as forced marriages seem to be the predominant themes of these ten dramas under study. With regard to the above themes Saule (1988) as quoted by Makosana (1991:8) comments:

Kukangaphi sisiva ngamabali angokungalungi konyanzeliso lomtshato; Kukangaphi sisiva ngamabali angokungalungi kobani basezidolophini, kukangaphi sisiva ngamabali angeengxabano zomtshato...? lingcinga ezintsha ziyafuneka.

How many times do we hear stories about forced marriages; how many times do we hear stories about the corruption of city life; how many times do we hear plays about conflict in marriages. There is a need for new ideas.

In this section, dramas with the theme of forced marriages will be treated together and so will be the case with dramas whose theme is women abuse. This section will therefore be divided into two sub-sections as follows:

\subsubsection{Dramas with forced marriages as a theme}

Of the ten dramas under study, the following are those which dealt with forced marriages as a theme: 
Title

Buzani kubawo

UDike noCikizwa

Amaza

UFeziwe okanye inkohlakalo
Author

W.K. Tamsanqa

A.M. Mmango

Z.S. Qangule

D. Mtywaku

Authors of the above mentioned dramas seem to be desperate to reclaim the dignity of women and in the process they forget about dangers of emphasizing it too much at the expense of their women characters.

In Tamsanqa's Buzani kubawo, NomaMpondomise is forced against her will to marry Mcunukelwa whom she does not love. She loves Gugulethu. Gugulethu proposes to her by letter and NomaMpondomise informs him by letter again that she has accepted the proposal. Gugulethu is also forced to marry Thobeka against his will. Preparations for Gugulethu's marriage reach the advanced stage of the payment of lobola as well as marriage ceremony preparations, but still NomaMpondomise is not informed about this serious state of affairs by Gugulethu. That is why, while Thobeka's lobola is being paid, NomaMpondomise drives out the cattle that are paid for lobola by Mcunukelwa. She does this with the understanding that Gugulethu has offered to marry her. Unfortunately her wishes are not fulfilled because she reads about Gugulethu's wedding in the newspapers. Because these authors see the practice of forced marriages as being unfair, their dramas are subordinate to their ideals. That is why certain events in the dramas are not clear or motivated. There is something common in all these dramas whose theme is forced marriages: The obstacles to one's way because of tradition are removed by death. The main problem in Buzani kubawo is solved in a tragic manner.

In uDike noCikizwa, Cikizwa is also forced to marry Mjongwa whom she does not love. She loves Dike. Even in this drama, the author advocates change. She overemphasizes the importance of protecting women from being oppressed by stereotyped customs like forced marriages. She introduces lovers who are victims of a traditional system in the form of a forced marriage. Cikizwa strongly criticizes these stereotyped traditional practices. In forced marriages, one is deprived of one's rights, hence Cikizwa says that: 
Kubi ukuphila kweli lizwe-ilizwe lamasiko lesithethe nemithetho, izinto ezithi unenyama negazi nengqondo nje zikwenze ufane nesigodo somthi esilindelwe ukubaswa. Ndisitsho nje ndiva intlungu yokuthobela umthetho katata umthetho ondiphanga bonk'ubantu bam, undenze ndibe yigusha efuyiweyo. It is painful to live in this world of customs, traditions and laws, things which though you have flesh and blood and brains, make you an inanimate object like a log of wood that is ready to make a fire. I say so because I feel the pain of obeying my father's authority, an authority that deprives me of all my humanity and makes me no better than sheep.

It transpires also from the dialogues of characters that women ultimately subscribe to cultural constraints like forced marriages:

uCikizwa: Ndicinga ukuba ukuthobel' umthetho wabazali yinyani

Cikizwa: I think that it is the truth that we should obey our parents.

Indima 3, Umboniso 1:20

Act 3, Scene 1:20

Having subscribed to cultural constraints, women then according to these dramatists suffer from self-pity because they are disregarded by customary laws. That is evident in Cikizwa's words:

Athi ke mna sidalwa singumfazi! O! Dike wam! Ndivelele kule ntsunguzi. llizwi lakho malindikhuthaze. Ubukho bakho mabundomeleze.

O! Woman! O! my Dike! save me from this darkness. Your voice must encourage me. Your presence must strengthen me.

Indima 3, Umboniso 1:22

Act 3, Scene 1:22

Ndingumfazi ngaphandle. Mandibe yindoda ngaphakathi. Mandikrote ndomelele. Ewe, mandizame ndilwele ubomi benzolo nolonwabo. Ubomi bethu Dike wam.

I am a woman externally. Let me be a man internally. Let me be brave and strong. Yes, try and fight for a peaceful and happy life. Our life, my Dike.

Indima 3, Umboniso 1:25 
In these dramas, themes depicted by authors force some of their characters to die by committing suicide after having tried desperately not to conform to the cruel customary traditional ways of forced marriages which symbolize subordination.

In Qangule's Amaza, Namhla is also forced by her foster parents to marry Sidima and yet she loves Lizo. She does not believe that a marriage should be arranged by the community. She rebels by drinking heavily. Namhla fights boldly against the idea of a forced marriage but sadly like other characters in the other dramas, she does not end up marrying Lizo. The author does this deliberately for many reasons, but the one which is relevant for this section is that of injustices against women in the form of forced marriages.

Mtywaku in uFeziwe okanye inkohlakalo depicts signs of resentment against the idea of forced marriages. Feziwe, who is an orphan, is forced by her uncle Kwedinana to marry someone she does not love. In her case it is the "ukuthwala custom" that is practiced. Feziwe is saved from the predicament by the death of her "husband", but at the same time she suffers severely.

The influence of the theme in the portrayal of the women in dramas of the first period

Because of their theme, which they want to articulate, authors like Tamsanqa in Buzani kubawo portray poor characters like NomaMpondomise whose actions are not motivated. As already been argued, her portrayal is exaggerated for dramatic effect.

In uDike noCikizwa, Cikizwa is endowed with characteristic traits that one gets from the focalization of the author on the action of the character. These are traits, which are taken and linked up with the intention of the writer. Cikizwa is depicted as a weak character who suffers. Some of her actions are not motivated: She confesses her love for Dike but they never meet. This is a deliberate attempt by the author to show injustices against women.

In Amaza, Namhla is portrayed as a suffering character because she is forced to marry Sidima against her will. Although she is at first portrayed as a strong character, fighting for her rights, but she does not achieve her goals. This is done deliberately by the author to enforce his theme of injustices against women. The author tries to destroy women oppression by depicting his women characters as stereotypes who are larger than life. 
In uFeziwe okanye inkohlakalo, Feziwe is depicted as a weak character who suffers a lot. Everything is done to her and she does not fight back. She is forced to marry someone she does not love by Kwedinana. She is assisted by Nomathamo in her attempts to fight for her rights of choosing her own life partner. When being forced against her will to marry, she does not bother herself of trying to inform her lover Thandile. It is Nomathamo who tries desperately to inform Feziwe's lover about Feziwe's predicament. Ultimately she meets Thandile by chance in Pietermaritzburg which is an obvious coincidence by the author for the two to meet so that they get married. The author wants to show Feziwe's long period of suffering in order to force the theme of injustices against women. Feziwe is therefore poorly portrayed because of the author's theme.

\subsubsection{Dramas with women abuse as a theme}

The following dramas in this study deal with women abuse as a theme:

$\underline{\text { Title }}$

Inene nasi isibhozo

Ubusuku obungenanyanga

lintombi zinecebo

Emgxobhozweni

Yeha-a mfazi obulala indoda

linkunzi ezimbini
Author

A. Mtingane

D.M. Jongilanga

R. Mcimeli

B.B. Mkonto

L. Ngewu

H. Mothlabane

Just like dramas, which deal with the theme of forced marriages, dramas on women abuse as their theme do affect the portrayal of women characters.

In Inene nasi isibhozo, MaSukude is portrayed as a suffering character. All the other characters' actions against her especially men, reinforce women abuse. This woman character is not poorly portrayed because her aggressive attitude is clearly motivated by the author. She is under severe pressures from different angles. She is a widow who is oppressed by in-laws who, without her involvement, appoint themselves as overseers of her household. She is a strong character but because of severe stress she ends up depending on her evil friends like No-ayini for evil advices. Her efforts of freeing herself from the bondage of oppression by in-laws ends disastrously. 
In Jongilanga's Ubusuku obungenanyanga, Novayithi is abused by her husband. Her husband is not working and he forces Novayithi to beg for food from their neighbours. Novayithi is always submissive and does not force her husband to look for a job or beg for food himself. He even goes to the extent of physically abusing her, but still Novayithi does not protest. Her friends do advise her on how to stop her husband from abusing her, but she would not listen. She is exaggerated for dramatic effect. She suffers until the end of the drama because even though her husband gets a job in East London, he comes back with a girlfriend who claims to be his wife. Novayithi's actions are not motivated at all.

lintombi zinecebo, written by Mcimeli is a farce, which is full of humorous incidents concerning women characters. Nomhle is abused by her brother Mvuzo. She is pregnant and she is not sure who the father of her baby is because she has two boyfriends, Vukile and Madoda. Mvuzo forces both men to pay Nomhle's pregnancy damages, which is not done in Xhosa culture. It is usually one man who is responsible for the payment of such damages. Nomhle is suffering because she is forced by Mvuzo to claim that they are both fathers of her child, but that should be a guarded secret from each boyfriend. Mvuzo does not hide the fact that he wants to enrich himself and in the process, Nomhle would benefit as well. This problem of Nomhle takes a long time before being solved in a humorous way and Nomhle is rewarded at the end of the drama because she marries the man she loves best of the two. Mcimeli decides to depict women abuse in a humorous manner.

In Mkonto's Emgxobhozweni, No-ankile is the one who is portrayed as an abused woman character. She is portrayed as a greedy and devious character who always tries to assassinate people's characters in order to achieve her own motives. She is portrayed as someone who is jealous of her husband's daughter by the first wife. She wants to be sole manager of her husband's businesses while her husband shows her clearly that he will not succumb to her demands because he is a man and she is a woman. No-ankile's actions are also not well motivated. Once more, this is a deliberate attempt by the author to assert the theme of women abuse.

The theme of women abuse is also evident in Ngewu's Yeha-a mfazi obulala indoda. Nozinto is abused by her husband. Ngewu informs us about this abuse by the use of flashbacks which is a good technique to motivate Nozinto's actions. Seeds of hatred in her are sewn such that she decides to kill her husband, who deprives her of her rights as a married woman. Nozinto's husband is a professional dancer who is said to be in love with 
one of the dancers and is even prepared to marry her. It is this type of ill-treatment that forces Nozinto to not only hire assassins for her husband on two occasions, but also to prepare joyfully for the funeral.

Mothlabane in her linkunzi ezimbini is concerned with the theme of women abuse as well. She does this in the form of polygamy in which Nolasti is one of the sufferers in that kind of marriage. Nolasti is a strong character. She fights for her rights. She feels that she has no voice in the running of the affairs of her household. She always challenges her husband Sigqibo on her rights as a woman. Sadly, she is abused physically by her husband and advised by her employer to lay a charge against him. She decides to go home to her mother who confronts her for not respecting her husband as the head of the family. Interestingly at the end of the drama she decides to return to her husband Sigqibo and be submissive to him. Anyway that does not surprise one completely because of the title of the book, linkunzi ezimbini, no two bulls can bellow in one kraal as well as the theme of the drama.

\subsubsection{Conclusions with regard to the portrayal of women in the Xhosa dramas}

It should be noted that in later dramas women characters have changed and this is brought about by more concentration on abuse unlike dramatists of the earlier period who concentrated on forced marriages. Some women characters of the early period used to be submissive to the practices of forced marriages because culturally a woman is supposed to be submissive to male dominance. Women characters of the late period always fight for their rights. They are not submissive. They resist abuse and forced marriages. In most cases this usually ends disastrously and there is always a lot of blood spilled.

In attempting to re-define themselves, women characters in the late period face the anguish of being doubly marginalized as women and as members of an already subordinated racial group. For instance, Nolasti faces violent confrontations from the other wives of her husband because she is not submissive. Some women like Nomhle of lintombi zinecebo symbolize strong women who persevere against all odds and ultimately emerge victorious. Nomhle does suffer but ultimately she emerges victorious because she attains her goals and wishes. 
In these dramas, one identifies the theme about the conflict between the old and modern tradition as well. The authors' women characters in these dramas have different views and beliefs. Some are dependent entirely on their husbands while others do things independently and take life challenges on their own. For instance, Nolasti of linkunzi ezimbini is a woman character of that calibre.

It is clear from the dramas that African tradition and modern ideas permeate Xhosa plays. Traditional and modern values and beliefs frequently surface in Buzani kubawo, Amaza, Inene nasi isibhozo, uDike noCikizwa and uFeziwe okanye inkohlakalo.

These dramas are a clarion call for a change in a world dominated by men. Another concern which Jongilanga conveys in his play is the powerlessness of women. Through his drama, Mtywaku is forcing the representatives of traditions to face oncoming changes. Feziwe, in Mtywaku's drama, insists on interpreting traditional values and conveying new ideas into social life. Mothlabane in her linkunzi ezimbini valourize women's attempts at finding their own spaces.

Some dramatists, especially those of the first period $(1958-1965)$, force their themes against all odds. They even go to the extent of breaking African customs and their characters do things which are not done in Xhosa culture as will be discussed in the chapter on culture. It is clear that these authors are all frustrated by injustices against women and then in the process they forget about their characters who must be true to life.

These Xhosa dramas treat thematically issues which become central to the formal and structural ordering of the drama and such themes have an impact, at times on form and structure. There are no clear differences from these writers about how they see women.

\subsubsection{A comparison of the portrayal of women in the drama and the universal view of women from the viewpoint of gender studies}

Bonvillain (1997:27) considers that the literature on women, both feminist and antifeminist, is a long rumination on the question of the nature and genesis of women's oppression and social subordination. More importantly, so she elaborates, the analysis of the causes of women's oppression forms the basis for any assessment of just what would have to be changed in order to achieve a society without gender hierarchy. 
Thus, if innate male aggression and dominance are at the root of female oppression, then the feminist programme would logically require either the extermination of the offending sex, or else a eugenics project to modify its character. According to Billing (1997:9) gender is a historical phenomenon which is understood, developed and changed differently in different cultural contexts and times. In elaborating on this aspect, he declares that men, women and gendered practices are dynamic, at least in modern society they were different a decade ago and they will be different in the future.

In Billing's opinion, the purpose of gender studies is to facilitate advanced thinking and reflection about gender and, thereby, about social relations, society organizations and working life in general. Pertaining to this line of thinking, everything thus bears a significant gender meaning and reflects or constitutes gender bias, normally to the advantage of men or to forms of masculine.

According to Friedman (1989:10), in some cases the image of women languishing under the yoke of oppression titillates and permits men to place themselves in the superior position.

Marsden (1994:2) advises that the subject of representations of South African women cannot be viewed from the single dimension of the written text. She thinks that representations have to be contextualised against the broader backgrounds of South African and African literature and literary critical theory. This in turn has to be contextualised against the social, historical and political backgrounds which produced them.

Women in Xhosa dramas of the early period are always depicted as victims. In the later period in drama depictions of women there are indications that perceptions that their cultural role and status are undergoing changes.

In the ten dramas under study, the poor image of Xhosa women is vivid. The ten dramatists seem to be committed to the use of women characters as an artistic medium of expression and committed to the furtherance of African cultural revolution in the sense that their works serve as pointers to moral issues for new changes. They moralize to their readers to the extent that their moral lessons could amount to a full sermon. In these works, women are seen to be generally constrained in their lives and in the process 
authors portray traditional oppressive gender stereotypes. The dramatists under study suggest that women are submissive, they are easily abused and they run away from their problems by committing suicide. They suggest that the solution is not a change of attitude on the part of women, but a change in the constraints produced through gender roles in the family.

The point here is not to say that there is no women abuse in Xhosa society. Indeed, fragments of abuse appear here and there. The condoning of oppression of women has been an unfortunate and painful reality of our life in this land which has caused a deep wound. Nevertheless the authors' exaggeration of this theme is unacceptable.

Their weak characters, some of them paralyzed by indecision who will not do anything against a father's will, spoil not only the plot structure of a drama, but also their character portrayal. Their characters lack depth. They create flat characters whom some critics might call cardboard and impersonal. They also lack the richness of original dramatic devices.

The dramatists' plots are often downright frustrating. The crudity and abruptness and often sentimental treatment with which they rush us through the problems of injustices against women sometimes offends the reader and the critic who looks not only for the message in a play, but the skill and craft of the art of play-writing.

Some of the dramatists under study especially Mtywaku, Tamsanqa, Mkonto, Mtingane and Mcimeli use their characters as inadequate vehicles for the portrayal of women abuse.

The portrayal of women in these dramas forces one to compare their views with reality. Xhosa women are not like this portrayal at all. Xhosa women are not submissive. They are not easily abused because they speak their minds. Even in the rural areas where we usually refer to them as amaqaba embola ebomvu (traditionalists of the red ochre), they are not submissive. They are not easily abused because they are respected and they do participate in their household affairs. There are even female-headed households as a result of migrant labor, desertion and widowhood.

There are no forced marriages. Arranged marriages are still practiced even nowadays in certain places such as the former Transkei. This type of marriage is often accompanied by 
lobola not for the purposes of enrichment as suggested and portrayed in the dramas under study. Lobola legalizes a marriage and it gives a married woman status, respect and dignity. In her discussion of gender in Xhosa proverbs, Ntshinga (1995:11) has this to say about lobola:

The Xhosa expression, sezivele ngeempondo [They (cattle) are already appearing by their horns], is an expression traditionally used to express appreciation of a growing girl and her capabilities to do household chores.

The significance implied here, she suggests, is that the young girl is getting closer to the stage of being married off in return for cattle. To prove that lobola entails status and respect, Ntshinga contends that the number of cattle is usually determined by the status of the girl's family.

The various forms of lobola payments suggested by Mtywaku in uFeziwe okanye inkohlakalo and Mcimeli's lintombi zinecebo are not practiced at all. There is a lot of exaggeration.

Women have a wide range of strategies of resistance. They know their rights and they are not powerless. They are also very knowledgeable about their societies. They are capable of making sense of their experiences in a patriarchal society. They are active and vocal because they do not believe in suffering in silence. They have initiatives. One might even be tempted to think that it is the men who are abused by the women in real life. 


\section{CHAPTER 6}

\section{THE DEPICTION OF CULTURE IN THE XHOSA DRAMA}

\subsection{AIM}

The culture we live in Van der Vijver et al. (1990:60) once said, is the totality of socially transmitted beliefs, meanings, values, ideas, norms and institutions that form the background of our lives. The cultural practices in some cases, which transmit such beliefs, are oppressive but it does not follow that transmitting them is harmful. It is harmful only when it causes setbacks to interests, interests consisting of getting what one wants.

The aim of this section is to list and analyze the various aspects of culture, which are portrayed in various Xhosa drama books under study. An exposition of how the playwright sees these aspects will also be given. The section is set out to discover the ways in which the broad cultural perspectives of the authors shape the texts they produce. It will also be determined whether in each case the ideology of the class represented by authors is indeed reflected in the text, which is then flawed.

\subsection{MARRIAGE}

\subsubsection{Forced marriage}

Forced marriage is one of the cultural issues that are depicted in the dramas under study. Although forced marriages are rare today, it used to be common practice for parents to impose torture on their daughters to compel them to marry against their will.

Let us now explore parental and family influence versus own choice. Van Tromp (1947:32) offers an explanation about parental and family influence versus own choice. He declares that a Xhosa marriage contract is firstly a concern of the two partners involved, binding them in marriage. Usually the partners are not socially independent individuals, but more or less dependent members of their respective families. It is for that reason therefore that the marriage contract is also a family concern.

Furthermore, he says, the father has greater authority, though the son usually first approaches his mother who will then directly or indirectly bring the matter to the notice of 
her husband. Not only the father, but also his brothers may influence a marriage. Marriage issues are always discussed in the family courts (iinkundla) of the young man and of the girl because the consequences of the agreement will affect the whole umzi and not just he father's interests.

There are times when certain family members object either against the young man and his family on the one hand, or against the girl and her family on the other hand. These are free to discuss the question in the family court. This will influence the respective fathers.

If the young man decides to marry a certain woman who is not of bad repute, he will have his way, though his father may have tried to dissuade him. The girl is treated differently because in her case, she is expected to submit. Should the girl object, then she may be given a thrashing and perhaps a severe one. As a rule, the girl is not consulted, sometimes hardly knows anything about the marriage, but is expected to submit. As a good and obedient girl, she is considered tacitly to consent to the marriage with a man of her parents' choice. Should she however violently dislike the proposed husband, she may make an appeal to her paternal uncles who may or may not thereupon influence her father to cancel the marriage negotiations.

Van Tromp (1947:33) further explains that it happens that when a girl violently dislikes the proposed husband and his family she goes to the umzi of the young man to be married there, but then rubs her own excreta on to her face or she calls out the name of the father of her intended husband, saying that she does not want to be the wife of this man the son of so-and-so, thereby deliberately violating the hlonipha rule due to her father-in-law. All this is clear and sufficient proof of her unwillingness and she is let free to return to her people who will then restore the ikhazi. However, for this simple reason that she is expected to obey the wishes of her family, she will, as a rule, tacitly consent and marry the man though she does not love him.

Soga (1933:227) informs us that there are two forms of the initial step, which is taken preparatory to marriage. He says one is that wherein parents of a girl take the first step towards seeking a husband for their daughter. The other, he avers, is that wherein a young man is the first to make a move towards seeking a wife. It was customary in early times, and still is in some cases, for the father of a marriageable daughter to look around for a suitable husband for her. The medium through which this search for a husband was 
conducted was either a relative of the girl or a close friend of her parents. The parents, if satisfied with the young man chosen, send him an assegai. This is regarded as a proposal of marriage. In all such cases it is not etiquette to refuse such a proposal unless the young man has good reasons for doing so. He may have objections to becoming connected with a family of bad repute, or of one accounted as wizards. In that case he would indicate his refusal to accept the proposal of marriage by returning the assegai to its owner. If, on the other hand, the young man is agreeable he retains the assegai. The father of the girl then takes steps to get her married. The young man in search of a wife adopts the same process.

Soga elaborates by saying that to have seen the person who brought the proposal, or its emblem, is insufficient guide to the family concerned, as to the source from which it came. The messenger takes care that he has been observed by members of the household. These messengers are called abahloleli (those who spy or the searchers). The duty imposed upon them is termed ukuhlolela (to spy for). UNozakuzaku (master of ceremonies) is appointed by the prospective bridegroom to carry on the negotiations till they terminate in marriage. This official is a very important person. He makes all arrangements for a coming marriage, supervises the slaughtering of cattle provided for the marriage feast, and sees to the food's proper distribution. Sometimes he acts along with the umhloleli (the searcher), and in this case acts as spokesman for the bridegroom. As a proof of the sincerity of the prospective bridegroom's intentions, the Nozakuzaku is asked by the girl's parents for isinyaniso (proof of sincerity).

\section{The portrayal of the cultural aspect in the drama}

In Mtywaku's uFeziwe okanye inkohlakalo, characters do not follow the custom as expected from the community. Even though his drama was written in 1982, he introduces the issue of forced marriages, which is rare nowadays. Once more he over emphasizes the issue of women's injustices. In his drama, the marriage contract, which is supposed to be a family concern culturally is addressed differently. The marriage agreement does not affect the whole umzi. It affects the father's (Kwedinana) interests and this character is not even the father of the girl. 
In Xhosa culture it is not merely a matter of cattle that is the deciding factor in marriage. The characters' status and health of the other family are paramount factors in securing a decision. Mtywaku's characters do not follow that deciding factor in Xhosa unions. It is not clear why Kwedinana chooses this particular man for Feziwe. The only thing, which is indicated, is the fact that Kwedinana is interested in Feziwe's lobola cattle.

In Buzani kubawo, Tamsanqa portrays a woman character, NomaMpondomise who loves Gugulethu and is forced to marry Mcunukelwa whom she does not love. NomaMpondomise's parents even go to the extent of accepting Mcunukelwa's lobola cattle. When NomaMpondomise attempts to give them her views about the forced marriage, her mother warns her that if she decides to drive out the lobola cattle, then she must replace them by other cattle from another man who promises to marry her.

In uDike noCikizwa by Mmango, the cultural aspect of forced marriages is identified as well. Cikizwa feels compelled by the way of life of her times that is regulated by customs, traditions and laws to obey them. She is fully aware of the consequences of her behaviour should she disobey them. Cikizwa is forced against her will to marry someone she is not in love with. She is in love with Dike.

Cikizwa's father, Sando, asserts that it is his right according to law to make provision for all the needs of his child, thus also marriage. Nomazala stands for tradition and as such she stands by Sando. She advocates the idea of a forced marriage. On the other hand, Nomatiletile sees no shame in Cikizwa's protest against a forced marriage. The dramatist uses Nomatiletile as a co-antagonist supporting Cikizwa. Nomatiletile advocates changes. According to the traditionalists, love has no role in marriage. Sando, Nomazala and their supporters believe that Mjongwa and Cikizwa should accept a forced marriage because an arranged marriage by two families will be blessed.

Cikizwa and Dike show concern at the malpractice of tradition. On the other hand, Sando believes that he does what ought to be done in his tradition. The opposing views of the two parties are fertile ground for the germination of the seeds of conflict. This is a very well orchestrated technique by the playwright in order to boost her theme of the oppressive culture against women. 
In the very opening scene of Qangule's Amaza, Qangule introduces Namhla and Lizo who are engaged in a conversation advocating their love for each other. This contradicts the forced marriage of Namhla to Sidima. Danile, Namhla's father shows his disappointment when he sees Namhla and Lizo together despite the planned forced marriage. Danile refers to Lizo as ingqeqe (a small dog). This is a very insulting word among Xhosas, because it refers to a very useless dog, which does absolutely nothing besides mating. Clearly there is a clash of values here because modernists see nothing wrong in Lizo being with Namhla even if the arranged marriage is imminent.

In uFeziwe okanye inkohlakalo, Feziwe is forced against her will to marry someone she does not love. She loves Thandile but Kwedinana decides to practice the ukuthwala (to cry) custom to her thus forcing her to marry.

There is a lot of exaggeration on this cultural aspect because forced marriages are not even practiced nowadays among Xhosas. The girl's people are aware that a love-match is happier and more stable than one where the girl was forced into marriage. Parents will not, unless for good reason, disregard a possible marriage with a man she is in love with and force her to marry the man of their choice. If any considerable family interest is at stake, however, the will of the family prevails and she is considered to have no say in the matter.

\subsubsection{Marriage ceremony}

In the drama uDike noCikizwa, traditionalists like Sando believe that in a traditional marriage, no consent is necessary, a woman can be forced to marry against her will, but in contrast modernists like Dike and Cikizwa strongly believe that consent is necessary.

The interruptions during the marriage ceremony are surprising. First and foremost the marriage ceremony is the climax of the drama and yet the dramatist handles it in an unskillful manner. Ntsimbi's appearance and his plea about love is not necessary for the ceremony. He is not even known by the people. It is also not clear why Lola decides to intervene at such a critical stage with such dire consequences. 


\subsubsection{The lobola custom}

According to Van Tromp (1947:46), in a Xhosa marriage there is a transference, a handing over of a girl by her father (family) to the young man and his family, and at the same time a handing over of ikhazi or a part thereof at some future date by the young man and his family to the father and family of the girl. If not, then a very short time after the marriage a portion of the ikhazi will be handed over to prevent the people of the girl from exacting it under the ukuthwala custom. The transaction of lobola is one of the most important elements in the whole of the essential requirements of a legally binding Xhosa marriage, whether regular or irregular, and is never absent. Without lobola cattle there can be no marriage.

In Jongilanga's uBusuku obungenanyanga, Novayithi decides to go home because of her husband's ill-treatment. Later on, Solani, her husband decides to go to Novayithi's home to negotiate her return. It is discovered that Solani did not even finish paying lobola for Novayithi. Novayithi's family sends them back to fetch ukuthwala cattle as a form of punishment. To show how disrespectful and useless Solani is, his party does not go back to Novayithi's home. Novayithi breaks the custom and decides to go back to her umzi on her own. That is a disgrace in African culture.

In Mcimeli's lintombi zinecebo, Mvuzo forces his sister Nomhle's two boyfriends both to pay lobola for Nomhle. He does this alone without other family members.

In Mothlabane's linkunzi ezimbini, Nolasti decides to go to her parents' home after being abused physically by her husband. She decides to go back to her husband without his paying for the ukuthwala custom.

\subsubsection{The rules of ukuthwala in Xhosa culture}

Koyana (1980:1) explains that the word ukuthwala means, "to carry". Furthermore he says:

ukuthwala is a custom whereby, preliminary to a customary marriage,

a young man will forcibly take the girl to his home. 
He elaborates by explaining that the young man accompanied by one or two friends, will waylay her when she goes to the river to fetch water, or to the forest to get a head-load of firewood. The girl, though immediately aware what this is all about, namely that it is the road to marriage, always puts up resistance, but the resistance differs in degrees and no girl is known to have escaped from a thwala party. Later that day, messengers are sent from the young man's home to report at the girl's home that the people must not keep on searching, the child is there. Negotiations about the marriage and ikhazi then takes place, and if things go smoothly the girl is already a wife at her husband's home. Ikhazi is paid as agreed, and there is no question of damages for the thwala party. To put it in another way, Koyana suggests, any damages that might have been payable for the thwala merge with the ikhazi.

Furthermore Koyana (1980:1) informs us:

If negotiations break down, whether because the young suitor is persona non grata to the woman's people or for any other reason, the girl soon finds her way to her home. The father or guardian then becomes entitled to a beast, known as thwala or a bopha beast from the word ukubopha meaning to tie up. The idea is that it ties up or soothes the injury done to the girl and her people.

This custom, Koyana (1980:2) avers, imbued though it is with all or most of the elements of the common law crime of abduction, has not been declared to be contrary to public policy and where it has been performed no criminal sanctions have followed unless a charge of rape is laid against this abduction and the court finds that this is not a genuine thwala, but a trumped-up allegation of thwala designed to meet the charge of rape. The ukuthwala custom has made no favorable impression on westernized people, and it is not practiced by them.

Soga (1933:1) suggests another version of ukuthwala. To him, the term ukuthwala is applied to two forms of abduction that is to genuine cases of abduction by force and also the faked cases of abduction. In the latter, both the young man and woman have agreed to elope, but the woman does not wish to appear to be flouting her parents, and prefers to give her elopement the appearance of abduction. Soga elaborates by saying that a large number of ukuthwala cases are love romances. He explains that in many of these the 
term simply denotes that the couple have mutually arranged to elope, so that the girl's parents will be faced with a fait accompli if they are unfavorably disposed towards the young man. He declared that the girl agrees to this procedure in order to marry the man she loves, and escape from the man to whom her parents seek to marry her. There is no intention on the part of the man to evade lobola, but he is determined to have the woman of his choice.

Van Tromp (1947:63) differentiates between three forms of ukuthwala. They are:

i. Ukuthwala okungenamvumelano, also known as ukugcagca, elopement. There is no consent on the part of the parents before ukuthwala. Both families, or only the girl's family, are ignorant of what is happening. By pre-arrangement, the girl is carried off to the umzi of the young man's father. Her resistance is sham. Mutual consent of families and agreement as to lobola are achieved. Ukutyis'amasi should precede sexual intercourse.

ii. Ukuthwala kobulawu. This is a mutually pre-arranged plan between families. The girl is not informed and is carried to the umzi of the young man's father, either forcibly or consenting. The girl consenting, ukutyis'amasi as a rule, precedes sexual intercourse. The girl resisting, no marriage can ensue. Generally lobola is already agreed upon.

iii. The last form of ukuthwala has no specific Xhosa term. There is no consent of either family, or only the young man's family is informed. The girl resists and is forcibly carried to the umzi of the young man's father. Marriage can ensue only if the girl and her family consent. Lobola in principle is accepted. Sexual intercourse follows on ukutyis'amasi.

\section{The portrayal of the cultural aspects in uFeziwe okanye inkohlakalo}

In Mtywaku's drama, Feziwe is taken against her own will and it is evident that even if her mother was still alive she would be taken without the knowledge or consent of her family, that is her mother. Kwedinana once told Feziwe and her mother, MamCirha that as a head of the family he would do it by force. Mtywaku does this deliberately in order to 
highlight women abuse because Kwedinana does this for his own personal gain, which is in the form of lobola.

Koyana (1980:1) observes that no girl is known to have escaped from a thwala party. In uFeziwe okanye inkohlakalo, Feziwe and Nomathamo fight the thwala party and escape. Unfortunately for Feziwe, the thwala party wins later on because Feziwe is finally taken by force to the home of her husband-to-be. The thwala party does not follow the custom as expected from the community.

\subsubsection{Polygyny}

Muhanganei (1999:72) observes that:

... polygyny is the form of marriage in which a person is married to more than one partner simultaneously.

In elaboration, Muhanganei (1999:73) quotes Spencer (1992) who shares the above view by differentiating between two forms of polygyny, namely: polygyny and polyandry. Polygyny, he avers:

$\ldots$ is a form of marriage by which a man has married more than one wife on separate occasions without annulling prevailing marriages.

Muhanganei (1999:73) observes that polygyny is exercised especially by men who occupy important positions in the community or are wealthier than the average man.

Polyandry is when a woman is married to more than one husband simultaneously. It does not exist in Xhosa culture.

Van Tromp (1947:28) shares the above explanation of polygyny. He informs us that in Xhosa marriage a man may have as many wives as he can afford to lobola. Furthermore, he avers, a man of means and of status has more than one wife. The number of wives a man has, adds to his status. It gives him a large family, a greater following, a certainty that his name will not die out. 
Liberal women believe that polygyny violates women's rights and they therefore support monogamy, where a man marries only one wife.

In linkunzi ezimbini, Sigqibo is married to three wives. It is surprising that Sigqibo has three wives because he cannot afford them and polygyny does promote dependency. His wives rely on him for survival. It is at this juncture that Nolasti comes to his rescue because as a liberated woman she is working and she helps in maintaining the household financially. Nolasti obviously believes in feminist principles.

One can argue that one of the reasons why the author brings these two characters with conflicting interests, Sigqibo and Nolasti together, is because she wants to emphasize her theme about women's rights as well as injustices against them. Sigqibo is a headman so it is also possible that as a man of a certain status he wants a greater following as well as certainty that his name will not die. The legislature and administration influence polygamous marriages.

Van Tromp (1947:29) explains that marriages according to Xhosa law (native marriage in general) are legally termed customary unions whereas marriages of a Xhosa man and woman according to Christian or civil rites are spoken of as marriages.

Furthermore, he elaborates:

Customary union, means an association of a man and a woman in a conjugal relationship according to native law and custom, where neither the man nor the woman is party to a subsisting marriage.

$\mathrm{He}$ further explains that marriage means the union of one man with one woman in accordance with any law for the time being in force in any Province governing marriages.

In linkunzi ezimbini, Nolasti reminds her husband's other wives that she is married to Sigqibo legally unlike them who are common law wives and as such she has say in the household affairs. Nolasti expects to be respected because the form in which she is married to Sigqibo is more dignified and more civilized. 
Van Tromp (1947:30) suggests that this differentiation between being legally married and being a common law wife seems to be unnecessary. He asserts that a union contracted according to Bantu law is a marriage. According to Xhosa law, he confirms, such union has all the consequences of a legally valid marriage. He explains that the children of such a union are legitimate and the marriage legally binding. He observes that it is, in fact, a marriage according to Xhosa law whether we approve of it or not.

\subsubsection{Marriage proposal}

In Xhosa culture a girl does not propose to the man herself. She can just make signs, which indicate that she is interested in that particular man. That is the pride of the Xhosa girl.

In Mcimeli's drama, Nomvuyo tells Vukile that she loves him and she kisses him immediately thereafter. The aim of the author is to solve Nomhle's two boyfriends issue in a very playful, brilliant fashion because this is a farce.

\subsubsection{Engagement}

Van Tromp (1947:58) claims that engagement as a legal relation results according to Xhosa law, from an agreement between the young man and his family on the one side, and the girl and her family on the other side, confirmed or supported by the handing over of the sinyaniso or "earnest beast" by the young man to the family of the girl.

Van Tromp elaborates by saying that the engagement may be broken off on either side for some good and sufficient cause. He says that where the young man or his family without good and sufficient cause breaks off the engagement, the "earnest beast" together with the increase is lost as a penalty.

In Xhosa law, Van Tromp (1947:60) explains that there is no action for damages for breach of promise to marry. The father suffers no loss; he retains his daughter and can still marry her to another man.

In Buzani kubawo, NomaMpondomise lays charges against Gugulethu for a breach of promise. The author does this deliberately in order to punish Zwilakhe who forces his 
daughter against her will. His aim is to show the restrictive nature and injustices of traditionalism to free thinking characters like NomaMpondomise and Gugulethu. $\mathrm{He}$ preaches the freedom of choice in marriage.

\subsection{INHERITANCE}

\subsubsection{The heir being bound by tradition to follow his society's customs}

Gugulethu is the heir of Zwilakhe. He is therefore bound by tradition to follow his people's customs so that when he takes over his responsibility of being head of the household, he should be able to perpetuate the values of his people.

Gugulethu tries to convince his father that he is no longer a child and as such he would like to be given a chance to choose his own partner whom he loves since marriage is based on love. Zwilakhe uses his power as a parent and he justifies his actions by referring to tradition. It is further observed that whether the father applies his authority arbitrarily or not depends on his sense of duty, but there are no means open to a child to constrain his/her father.

In Buzani kubawo, Gugulethu is not prepared to succumb to his father's demands anymore. This intensifies problems between Gugulethu and his family as on the wedding day he refuses to repeat the marriage vows. He keeps on saying "ask father". This is a very serious crisis for his father. The conflict between Zwilakhe and Gugulethu leads to an unnecessary trail of deaths.

The author has achieved his goal of depicting the dangers of forcing customs and traditions to characters that are representatives of certain values that work for them. As Jafta (1996:385) puts it, in Tamsanqa's work we observe didacticism in the way the characters are depicted in a rigid form in the values they stand for. One shares Jafta's views when she explains that the parent's greed has turned them into human monsters that have lost all that is ubuntu in them.

The author forces Zwilakhe not to listen to his brothers thus breaking the tradition. Zwilakhe explains that he does not want to spoon-feed his son Gugulethu with a bride, but does just that. $\mathrm{He}$ is even deserted by his brothers like Zweni who withdraw from the marriage negotiations. 
Still on the issue of inheritance, Van Tromp (1947:5) explains that in African culture from birth to marriage, a female is under the guardianship of her father or his lawful heir and successor. Because she is a minor and a female, she cannot inherit. No female can in Xhosa law become heir (indlalifa) or succeed her father or husband in his estate.

The author in Emgxobhozweni is so pre-occupied with the theme of the book that he portrays the Xhosa custom in an unconvincing manner. Nomonde inherits her father's businesses not only because she is a hard worker who boosted the shop, but also because the author wants to punish the devious No-ankile. It is even said that No-ankile will get her little share only as long as she is married to Vakele. That is written in her husband's will.

\subsubsection{Control of the widow's homestead}

Concerning the control of the widow's homestead the author's male characters do not follow the Xhosa custom. After her husband's death, as explained by Van Tromp (1947:127) a widow is in more or less the same position with regard to the effects of the umzi as she was during his lifetime. The widow, according to Xhosa law retains her right to her personal belongings.

In Inene nasi isibhozo, Mfolo and Lolo control MaSukude's household. Mfolo says to MaSukude:

Mfolo: Nanku uLolo umninawe kaNjinge, oliliso lalo mzi. Ukuba kukho into ekuxakileyo okanye ongayithandiyo yibike kuye nibonisane ngayo nobabini.

Indima I, Umboniso I:6

Mfolo: Here is Lolo, Njinge's younger brother, who is the overseer of this household. If there is something that is bothering you or which you do not like, then discuss it with him, both of you.

Act I, Scene I:6

In one of the meetings of the Khwalo clan, Mfolo reminds the Khwalo men that they do not discuss family affairs with women and as such he does not expect MaSukude to attend the meeting: 
uMfolo: Ngaba imicimbi yomzi apha siyixoxa kunye nabafazi?

Mfolo: Do we discuss family affairs with women?

uLolo: Asiyilungisi nabafazi.

Lolo: We do not solve family affairs with women.

uMfolo: Lo ke umfazi uza kwaneka umcimbi womzi emadodeni, uza kusanekela ngabuni?

Mfolo: What about this woman and on what capacity will she be presenting family affairs to men?

Indima 2, Umboniso 1:24

Act 2, Scene 1:24

It is evident in this drama that MaSukude has no say. To articulate her anger MaSukude consults her friend No-ayini for advice. She is now an irresolute character. No-ayini comes up with very dangerous advice, namely that of poisoning Themba. This is because Mfolo and Lolo go to the extent of deciding who of the two sons, Vuma and Themba, will be the first to marry.

The two characters, Mfolo and Lolo, seem to forget that after the death of her husband, the widow becomes free of all control and is entitled to claim in her own right all property she may have acquired since her husband's death. Mfolo and Lolo's behaviour inflicts a hardship upon MaSukude. This results in a lot of unnecessary deaths.

\subsubsection{Seniority of sons}

Lolo argues with MaSukude about who should be the first of the sons to marry. He forgets that as a widow who lawfully has even a greater say in the affairs of her household, MaSukude is free to make a decision. Lolo says:

uLolo: ... Phofu, kutheni kuza kuqala uVuma, ekho nje uThemba?

Indima I, Umboniso 7:21

Lolo: ... But, why must Vuma be the first to marry when Themba, the elder, is actually here? 
MaSukude wants to help Vuma with the lobola cattle in his marriage because he is the one who has long been taking good care of his home:

uMaSukude: ... Akunakuze kuzekelwe itshiph'elagqiba ishumi leminyaka eKapa, ekh'uVuma umntu obelima egcine nezi nkomo.

Indima I, Umboniso 7:21

MaSukude: ... We can never pay lobola for someone who disappeared for a period of ten years in Cape Town, whereas Vuma has long been ploughing and looking after cattle.

Act I, Scene 7:21

Lolo sticks to the custom that Themba is the eldest and as such he must marry first. Lolo passes this problem on to a meeting of the clan knowing full well that women are not allowed to speak. In the Khwalo meeting Mfolo forcefully instructs MaSukude to leave and go to the kitchen where she belongs. They cannot discuss anything with her and she will only be called in order to be informed about the decision of the meeting:

uMfolo: $\quad$ MaSukude, thatha l-emele uyokukha amanzi, upheke, sakukubiza xa sikufuna.

Indima 2, Umboniso 1:25

Mfolo: $\quad$ MaSukude, take a bucket, and fetch water and we will call you if we need you.

Act 2, Scene 1:25

These men even joke and laugh at MaSukude. Mazwazwa is one of those characters who are amused by MaSukude's treatment. The author breaks the custom deliberately. MaSukude, according to the custom has even greater powers in the absence of her husband. She has more say in the affairs of the umzi than she had when her husband was still alive.

The portrayal of characters like Mfolo, Lolo and other members of the Khwalo clan suggest that Mtingane, the author, has a formula regarding the exploitation of women. A critical analysis of MaSukude's portrayal serves as a good illustration of the author's aim. 


\subsubsection{Mother's position when the son marries}

MaSukude sees the marriage of Vuma as the reason for the removal of Lolo. One wonders why, because according to Xhosa culture, after marriage a son is usually given the right to leave the umzi and build an umzi for himself. Even in this case, the mother and relatives in the absence of the father still have an interest in this son, and all cases concerning family affairs in which the son is involved must be tried at the umzi of his father. Law, Van Tromp (1947:64) explains, cannot enforce this interest. It is only a moral obligation, which the son owes his parents.

MaSukude says to Vuma:

MaSukude: ... Mntwan'am, ndikhathazwa nguyihlomncinci. Okoko kwathi kwabhubh'uyihlo, lo mzi uLolo uwenz'owakhe.

Indima I, Umboniso 5:13

MaSukude: My child, I am bothered by your uncle. Ever since the death of your father, Lolo thinks that he owns this household.

Act I, Scene 5:13

MaSukude continues:

MaSukude: ... Kodwa makathi ukuba uyabuya, abuye sekudala wazekayo, unezinto zakho...

Indima I, Umboniso 4:12

MaSukude: ...But by the time he comes back, you must have married long ago with your own properties...

Act I, Scene 4:!2

Vuma's marriage cannot be a solution to any of MaSukude's problems. This is just a deliberate attempt by the author to show the dangerous consequences of ill-treating women. MaSukude poisons Themba and this leads to Vuyiswa's suicide. Vuma and Lolo are also killed accidentally. There is just an unbearable blood bath, which is unnecessary. 
The lobola issue that is of tremendous significance among the AmaXhosa is not handled properly. The narrator in Act 3, Scene I, summarizes it when he says:

\section{Umcacisi: Kulotyolwe kwaphindwa kwamkhozi}

Narrator: The lobola negotiations continued repeatedly at the bridegroom's place.

The narrator summarizes everything concerning the payment of lobola and marriage negotiations.

Concerning the marriage procedure, Van Tromp (1947:54) explains that when all arrangements have been made, the wedding outfit and other gifts to the bride are complete and the people of the young man are ready when the time arrives for the bride's to go to the umzi of the young man's family to be married there. For this purpose, he elaborates, her own family will select men and women to form the uduli or bridal party, who must accompany her and who have formally to hand her over. The parents of the bride never go with the bridal party. The impothulo and perhaps the ubulunga beasts accompany the bridal party.

\subsubsection{Mfolo's and No-ayini's speeches about women rights}

In his speech, Mfolo explains that women have no say in the affairs of the household and moreover men cannot discuss and solve household's affairs with them. He believes that the woman's place is in the kitchen hence in the middle of their discussion, he instructs MaSukude to go to the kitchen where she belongs. This is also against Xhosa culture.

This is exaggeration by the author in order to emphasize his message or theme about women's objectification. The author makes MaSukude to feel empty, oppressed and nonexisting. He creates a negative aspect of objectification against MaSukude, which is described by Dowling (1997:15) as:

... the psychic scar tissue that results of living with the expectation of being a battlefield sacrifice, which is horrible as the suffering women bear from the fear and the reality of rape. 
Like other dramatists under study, some of his characters do not follow the Xhosa custom. No-ayini, even says openly that men of modern times think that women are their idiots:

No-ayini: Ngumthetho wenu madoda eli xesha, ukucinga ukuba abafazi aba zizidenge zenu

Indima 2, Umboniso 3:30

No-ayini: It is common practice among you men of modern times to think that women are your idiots.

Act 2; Scene 3:30

\subsubsection{The ukungena custom}

The Bheles and Cirha camps agree unanimously that an African custom known as isiko lukungena should be imposed on Namhla after the death of her husband in the drama Amaza. Several African societies do observe this custom. They believe that there can be no compromise concerning it. That is not the case among Xhosas. The Bhele and Cirha clans state that:

Namhla Bhelekazi, sikubizela into eqhelekileyo. AmaCirha angwerela ukuvusa umyeni wakho ngomnye woonyana. Isiko lisiko akuthandiswa wena.

Indima 3, Umboniso 2:61

Namhla Bhelekazi, we have summoned you for a common practice. The Cirha wish to resurrect your husband by marrying you to one of their sons.

This is a custom, and may not be opposed.

Act 3, Scene 2:61

Namhla who believes in her values shouts at the traditionalists.

\subsection{WOMEN'S RIGHTS}

Bennett (1995:80) explains that the status of African women is dictated by a deeply entrenched tradition of patriarchy. He observes that patriarchy is generally understood to mean the deference due to males, or more precisely the control exercised by senior men over the property and lives of women and juniors. Women, he observes, are judged as being unable to form a proper judgement. They are therefore assimilated to the status of 
children and, like children, they are subordinated to the control of senior male guardians. Bennett elaborates by saying that to the contrary, if a woman were wronged, her dignity as a human being would be recognized and she would be entitled to claim redress for any damage she suffered. He believes however that she would not be allowed to take action directly.

According to Bennett (1995:80), patriarchy has far-reaching and diverse implications. He says that because women can occupy no positions of authority, they are expected to remain silent and submissive. A woman must be prepared to accept her husband's decisions in all matters. Female activities are almost always judged inferior to men's. Obviously, Bennett elaborates, many women refuse to conform to this regime and many individuals lead active and productive lives. Whatever women do to mitigate their lot in life is liable to be stigmatized as anti-social or subversive. Women, Bennett observes, live in virtual bondage.

In linkunzi ezimbini, Sigqibo forces total control of his wives' lives. He does not believe that his wives can form a proper judgement. He quarrels with Nolasti who does not consult him with baby-sitting at her employer's place. He also does not want Nolasti to have anything to do with the choice of their son, Luvuyo's school.

When Sigqibo hits Nolasti, she is not expected to take action directly. That is why everybody raises eyebrows when she lays charges against her husband. Nolasti refuses to conform to this regime and injustices. She feels that she lives in virtual bondage and as such she wants to free herself. Sadly, she is stigmatized and does not get any support from the other wives of her husband. She is labeled as a troublemaker. At one stage Sigqibo says to Nolasti, to show that her status is reduced to that of a child:

Sigqibo: Ungumfazi, into oyiyo yaye andizukuva ngawe...

Sigqibo: You are a woman and you will not control me.

Somewhere in the play, Nolasti loses hope and she misses her man who turns his back against her because he does not want to be challenged by a woman. One cannot help but empathize with her. She is lonely because she is deprived of her rights as a wife. She swallows her pride and says to Sigqibo, who refuses to spend the night at her place: 
Nolasti: $\quad$ Yhini wethu sithandwa, ngoku besendizithembise ukuba uza kulala apha namhlanje. Sowuxola kaloku ulale andizukuthetha nto ngemfundo kaLuvuyo.

Nolasti: $\quad \mathrm{O}$ my dear, I have already promised myself that you will spend the night with me today. Forgive me and sleep, I am not going to talk about Luvuyo's education.

These sad words by Nolasti do not touch this hardened man, Sigqibo. He forcefully takes his jacket and leaves the frustrated heart-broken woman. Nolasti painfully peeps through the window and sees the love of her life going to enjoy himself at Nofinishi's house. She is devastated because her husband does not spend the night with her anymore.

Nolasti suffers because in Xhosa culture, upon her marriage, a wife falls under the guardianship of her husband. The social duty of the wife is to conduct herself with the utmost dignity and she must take care that her deeds do not tend to cause trouble. A quarrelsome wife may be repudiated. It is her duty to uphold the status of the umzi to keep to the hlonipha rules.

Concerning the rights of a wife, the general idea that a Xhosa wife has no rights that she herself is the property of her husband and is treated as a chattel by him, Van Tromp (1947:100) explains that it is incorrect. A wife has the right to come to her husband when her person or rights are assaulted and demand protection from him. Should she have to institute an action against her husband she will complain to his brothers or to the sub-chief, who will take the matter in hand.

If her husband assaults or injures her, she has the right to go home to her own people when she has an opportunity and they will then resort to the ukutheleka custom.

\subsection{ABUSE}

Van Tromp (1947:167) explains that the AmaXhosa has never recognized this as being sufficient to cause dissolution of marriage. Furthermore, he suggests, the woman used to avail herself of the protection of the ukutheleka custom. Gross ill-treatment is a ground for the dissolution of a marriage, and also the forfeiture of the lobola cattle. 
When a husband, by ill-treatment, drives away his wife for no reasonable cause, it is, under African culture, a bar to the recovery of the dowry paid or a reasonable ground for a portion of it being withheld. But in such a case the woman will go to her people and remain there.

In Yeha-a mfazi obulala indoda, we learn that Nozinto is ill-treated by her husband but she does not even consult her in-laws. She relies on friends and decides to hire assassins to kill her husband. The author does this deliberately because he wants to demonstrate how bad women can be. He has even written the theme of the book on the outside cover. He explains that Nozinto hired thugs to murder her husband with the aim of benefiting from his insurance.

In African societies marked by patterns of male dominance, women often subscribe to the norms that define men and women's activities and to the cultural constraints on their gestures, language use and movement.

Nozinto feels that she has no confidence in a woman lawyer but later on she realizes that this lawyer is the one who can empathize with her. This is the result of various cultural constraints.

Under male dominance it is assumed or expected that women are powerless and submissive individuals. In patriarchal society, Nozinto is expected to be submissive and not to question her husband's bad behaviour because she is a woman. One does not condone Nozinto's killing of her husband. Nozinto's actions show that women are knowledgeable about the societies they live in and negotiate in their daily actions to make sense of their experiences in a male-dominated society.

\subsection{FUNERALS}

Soga (1933:318) explains that death is an awesome thing to the Xhosa. He says that even if jokes are being cracked at the funeral that is done under the impression that they are helping to dispel the gloom and lessen the weight of sorrow. Burial is a well respected occasion so one finds it very strange that the investigation officer decides to arrest Nozinto in church. The behaviour of the priest is also surprising especially when he already knows 
that it is a woman who is the cause of the late Zamile's death. This is the author's emphasis of how bad women can be.

According to African tribal traditions women do not go to the graveyard on the day of the funeral if the deceased died by accident or is murdered. Furthermore, there is no slaughtering whatsoever. The meal of condolence is inkobe.

In scene 2, Nozinto tells her father-in-law, Lolwana that she bought fifteen sheep to be slaughtered at the funeral. It is increasingly becoming the practice to invite mourners to partake of refreshments after the funeral at the home of the bereaved family. Nozinto wants to do just that. Lolwana informs Nozinto that the funeral is not a feast. If someone dies by accident, which could be in the form of murder, then the only meal for that sad day is the iinkobe, which is the meal of condolence. Lolwana says:

Lolwana: Mntwan'an, asenzi mgidi apha koko singcwaba umntu ofe ngengozi. Akuxhelwa ke xa umntu efe ngengozi into edliwayo xa kuqhushekwa umntu wengozi ziinkobe.

Indima 3, Umboniso 2:48

Lolwana: My child, we are not making a feast here, but we are just burying someone who died by accident. There is no slaughtering if someone died by accident. The only meal of condolence is iinkobe.

Act 3, Scene 2:48

\subsection{ANCESTORS}

\section{Appeasement of ancestors: burial of skin}

In Qangule's Amaza Silumko shows Namhla and Lizo the skin of a snake which has just been buried by MaNdaba near their house, thus trying to bewitch them. Silumko explains he is aware that Namhla and Lizo want to get married and as such they must do something about the snake if at all they are serious about getting married. He instructs them to bury the snake's skin in Sidima's grave. Silumko tells them that death is buried with another death.

The traditionalists believe that Namhla's actions are caused by the wrath of the ancestors. They suggest that one way of appeasing the ancestors is to brew beer, which is really 
common practice among Xhosas. Khulile reminds them that Namhla is baptized and therefore does not believe in ancestor worship. Nevertheless, this appeasement of ancestors by pouring beer at the door does not help at all. Namhla is even threatened by the wrath of ancestors as she does not cooperate with isiko lokungena.

\section{Majola snake}

In one of the African societies, namely the Amajola clan, the older people are well mannered and reverential with regard to the Majola snake. They believe that aberration from this results in abomination by the ancestors such as caused by Thembeka's unmanliness towards the mole snake in Ingqumbo yeminyanya. It is also believed that during the birth of a child this snake comes to visit and welcome the newborn child to make sure that the child belongs to this umzi.

In lintombi zinecebo a snake suddenly appears during the visit of Vukile's family members to see the child. To some of them this was a good sign because they doubted if Nomhle's child was Vukile's. They claimed that the child's features were completely different from Vukile's. Nevertheless the others claimed that the snake was just another type of snake and not one of the Amajola clan, that is the mole snake which visits to bless the child. Soga (1933: 88) explains that the mole snake is an epitome of the Mpondomise traditions and at the same time the father of the nation. Furthermore, he explains, a mole snake can be defined as a harmless species of the family Calubridae, which lives mainly on moles, rats, mice and other small mammals, which it kills by constriction.

\subsection{ILLEGITIMATE CHILDREN BORN TO UNMARRIED DAUGHTER}

According to Van Tromp (1947:144) the illegitimate child born to an unmarried daughter belongs to the umzi of her father. The child is recognized as an inmate of that umzi and as a child, though of minor status, of the house (indlu) in which the daughter who thus gave birth to this child belongs. He further explains that it is treated as any other inmate of the umzi though known to be illegitimate.

The boyfriend who is the cause of pregnancy pays the damages for defloration and pregnancy. He must produce isondlo as well. Van Tromp observes that the assertion that the natural father has a right to his illegitimate child and that the people of the girl must 
give up the child when claimed by its natural father is not Xhosa law. Even if he does pay isondlo he has no legal right to force the people of the girl to hand over the child to him. Whether he gets that child or not will depend upon the father of the girl.

Mvuzo does not follow the Xhosa custom. He does not involve his family members when visiting the homes of Nomhle's boyfriends. He demands the payment of damages on his own. His actions are even questioned by family members of one of Nomhle's boyfriends. Mvuzo breaks the African custom again by demanding payment of damages from the two men. It is clear that he does this for self enrichment and sadly at Nomhle's expense. Even this payment is too much.

\subsection{MALE DOMINANCE}

According to Van Tromp (1947:109) it is sometimes stated that a woman has the right to be consulted by her husband and it is his duty to consult her when he has to decide upon certain matters. Furthermore, he says, in Xhosa law, there is no obligation enforceable at law upon the husband to discuss all things with his wife. It is sufficient if he acts in consultation with the male members of the umzi.

Vakele in Emgxobhozweni does not consult his wife or male members of the umzi about the affairs of his household. He consults his sister Hombakazi and his daughter Nomonde. The author's male characters do not want to be controlled by their wives in the affairs of their homes. Vakele is not prepared to be told by his wife No-ankile how to run the affairs of his home. He does this not only because she is a woman, but also because the author has portrayed her as a very bad character.

In uFeziwe okanye inkohlakalo Kwedinana believes in male dominance. He feels that with the death of Feziwe's parents he is automatically the one who must be an overseer in the affairs of Feziwe's home. He goes to the extent of abusing her with a forced marriage. So is the case in Inene nasi isibhozo, Mfolo and Lolo appoint themselves as overseers of MaSukude's household, because she is a widow. She is dominated by Mfolo and Lolo and has no say in the affairs of her own household. 


\subsection{CONCLUSIONS}

Some authors do not have a clear idea how these culture issues work. Cultural issues have changed. Even the issues of forced marriages have changed. As has been observed in these dramas, authors are grappling with the problem of documenting women's position as victims of their culturally constructed subordinate status. At some stage, the reader feels that some cultural aspects are exaggerated. Some of their characters behave in a very irrational manner concerning the identified cultural aspects. The authors allow their characters to behave irrationally because they want to prove beyond doubt that there are unacceptable injustices against women.

The recurring of the issue of forced marriages clearly expresses their disapproval of the traditional arranged marriage where parents make choices for brides and grooms. The authors do not attack tradition and custom blatantly, but they express their disapproval of certain glaring abuses of tradition which impede progress.

There is distortion of cultural aspects like forced marriages, levirate custom (isiko lokungena) and ukuthwala custom. Culture distortions, to mention but a few, are identified in Inene nasi isibhozo. The way MaSukude is objectified as a widow is exaggerated. She has no voice in her household affairs. So is the case in Buzani kubawo. In uFeziwe okanye inkohlakalo, the ukuthwala custom is not portrayed according to the Xhosa culture. The way in which it is portrayed in the book is abuse and it is exaggerated. Distortion of culture aspects is also identified in uDike noCikizwa as well as lintombi zinecebo. My findings are that cultural aspects are abused.

Some of these dramatists have demonstrated not to be knowledgeable concerning the traditional aspects of drama. Drama must have value culturally. 


\section{CHAPTER 7 \\ CONCLUSION}

\subsection{AIM}

The aim of this section is to examine and conclude whether gender stereotypes and culture distortions by authors in the dramas are forces that are used to advocate change. This is done in the process of studying, analyzing and interpreting the dramas. An important aim is to make findings about whether there are indications in the drama depictions of women that perceptions on their status and cultural role are undergoing changes. Findings thereof will be demonstrated in the discussion of the woman as a character as well as the portrayal of women in the Xhosa dramas.

\subsection{THE WOMAN AS A CHARACTER}

\subsubsection{MaSukude in Inene nasi isibhozo}

A short survey of themes and women characters in the drama shows that there is a close link between themes and character portrayal. It would seem the author of the drama, Mtingane portrays his characters MaSukude and No-ayini in such a way that they represent the desired message: women abuse and male dominance.

MaSukude is a widowed victim who is made to suffer. She suffers a lot after the death of her husband, Njinge, because her in-laws abuse her. She decides to fight for her rights and those of her son, Vuma. She is portrayed as a cruel, evil and disobedient woman because she fights being dependent on her in-laws Mfolo and Lolo. One identifies cultural influences because among amaXhosa a married woman's freedom is limited. In African society, a married woman is expected to be dependent on her husband or on her in-laws if the husband is dead. MaSukude is portrayed as a woman with bad manners and without dignity unlike other African women. The reason for this portrayal is that she refuses to allow Mfolo, her husband's brother and Lolo to take over administration of her together with her umzi (household). As Jafta (1996:80) puts it, this foregoing helps to give a cultural background to the tragic conflict in the drama. There is therefore a clash of beliefs between MaSukude, who wants to uphold her dignity as a married woman, and the in-laws who demand respect from her. 
Conflict takes another step further when MaSukude challenges another tradition that Themba, MaSukude's stepson must marry first because he is an elder son. Once more MaSukude is portrayed as a stubborn troublesome woman who does not co-operate. MaSukude disagrees with her in-laws because her son Vuma has been managing everything at home while Themba has been away from home.

One identifies MaSukude being portrayed as a devious character who lacks morals because she is determined to change tradition that women cannot be involved in the discussions of domestic matters. Her in-laws forcefully cut her out of the meeting for the marriage plans for Themba and Vuma. She is portrayed as a bloodthirsty murderer who kills people in trying to solve her problems. This is demonstrated in her speech where she says that their Themba will marry over her dead body. She is therefore made to kill all the principal characters. As Jafta (1996:299) puts it, this becomes melodramatic because it is a terrible shock. In this drama MaSukude is oppressed and her character traits are conditioned by modes of representation and wishes for equality for all in all social activities, but unfortunately her portrayal is done in a stereotypical way. She is portrayed as a married woman who is opposed to tradition and wants to change it forcefully so that things go according to her will.

\subsubsection{NomaMpondomise in Buzani kubawo}

In Tamsanqa's Buzani kubawo, NomaMpondomise is forced to marry Mcunukelwa against her will. She loves Gugulethu. In the drama, the moral lesson is evident in the stereotypical manner in which the author portrays her. NomaMpondomise is portrayed as a weak, unreal character. Her actions are unmotivated. She drives out of her father's kraal lobola cattle paid for her by Mcunukelwa because she loves Gugulethu and not Mcunukelwa. Gugulethu and NomaMpondomise profess love for each other, but they never meet. She behaves irrationally because nothing is being said about the lobola cattle of Gugulethu whom she claims to love so much.

NomaMpondomise does not even know that Gugulethu is getting married to Thobeka. She only learns about it in the newspapers. How could she not know that her lover is getting married? She commits suicide thereafter. She is portrayed as a Xhosa woman who is easily abused and runs away from her problems by committing suicide. 


\subsubsection{Cikizwa in uDike noCikizwa}

Cikizwa is the protagonist woman character in Mmango's drama. She is portrayed as a pathetically weak character who is confused. She is confused in the sense that she wants to demonstrate her beliefs in tradition, but at the same time she wants to be given freedom of choice in marriage.

The protagonist is even easily swayed by other characters thus confirming her weak character. There are signs of cultural influence in her character because she wants to follow tradition and not defy her father who forces her to marry against her will. Cikizwa loves Dike and her father forces her to marry Mjongwa.

As in Buzani kubawo, Dike and Cikizwa profess their love for each other through the communication of letters. The author forgets to bring them together. Further cultural influences are identified in one of the letters Cikizwa writes to Dike. The letter entails tradition that forces her to obey her father against all odds.

At some stage Cikizwa is portrayed as a strong character when she becomes bold in church and stands for her rights. She refuses to sign the marriage register. Her father, Sando, boasts about killing Dike to whom he refers as a dog. Upon hearing this bad news, Cikizwa becomes devastated. The author portrays her as a weak woman character who commits suicide when running away from her problems. This is shocking and unrealistic.

\subsubsection{Feziwe in uFeziwe okanye inkohlakalo}

In uFeziwe okanye inkohlakalo, Feziwe is portrayed as a very weak character. She is poorly portrayed and appears constantly as the victim. Bad things are always done to her and she is heavily dependent on the other characters for strength. She is ill-treated by her father's brother (uncle) Kwedinana upon the death of her parents and she is too weak to defend herself. Nomathamo, her cousin comes to her rescue all the time even when she was forced by Kwedinana to marry an old man she does not love. Feziwe's submissiveness is an exaggeration of culturally accepted behaviour. She is not firm enough in telling Kwedinana that she has a right to choose a marriage partner. 
Feziwe's brother, Fuzile, comes to her rescue when she is forced by Kwedinana to go back to her would be umzi. This happens when she decides to run away from the dying husband. She has a lover by the name of Thandile but she does not take the initiative to meet him. She is helped by Nomathamo. She is really portrayed in a stereotypical manner for thematic concerns. Kwedinana keeps on abusing her because he even goes to the extent of hiring people to assassinate Feziwe's fiancé Thandile as they are preparing for marriage.

Upon hearing news of Thandile's death, Feziwe is devastated and decides to commit suicide. Feziwe is portrayed as a woman character who is easily abused and runs away from troubles by committing suicide. Mtywaku's portrayal of this woman character is unskilled because her actions are not motivated.

\subsubsection{Novayithi in Ubusuku obungenanyanga}

Novayithi in Jongilanga's Ubusuku obungenanyanga is depicted as an abused character. She is weak and unreal. She suffers because her husband demands that she makes ends meet at their poor home. Both Novayithi and her husbarid are not working but Novayithi is the one who is expected by her husband to beg for food. Her husband does not even appreciate her when she comes home with food. She is always humiliated by the other people in the village who feel that she is the one who makes her husband to be irresponsible. She does not punish her husband, who goes on a drinking spree everyday. When he comes back he demands food from Novayithi.

There are cultural influences in the portrayal of Novayithi and they are exaggerated. As an African woman she believes in obeying men against all odds. She does not question her husband's irresponsible manners. She suffers in silence under male dominance because of patriarchal rules. Her husband even goes to the extent of abusing her physically and it is then that she decides to return to her parents. Her husband decides to fetch her after a while and it is discovered that he did not even pay lobola. He is punished by his in-laws. They demand cattle and he never came back to fetch his wife. Novayithi swallows her pride and goes back to her umzi against her parents' will.

At the end of the drama, Novayithi is portrayed as a cruel woman character when she reacts violently to her husband who brings a girlfriend to their home. The girlfriend claims 
to be the wife of Novayithi's husband, after Novayithi throws boiling water on them. There is a lot of exaggeration concerning this male dominance. Novayithi is always undermined and provoked to such an extent that she loses her temper in the end. The author portrays her as a cruel character who solves her problems with violence. She is not real. Like other characters in the other dramas, she is portrayed in a stereotyped manner. There is an overexposure of an aspect of cruelty.

\subsubsection{Namhla in Amaza}

In Qangule's drama, Amaza, Namhla is depicted as a suffering character. She is strong in the sense that she does fight for her rights. She believes in the freedom of choice of a marriage partner. There is an overexposure of cruelty in Namhla's portrayal. She is an orphan and is brought up by her foster parents. Namhla loves Lizo and her foster parents force her to marry Sidima who she does not like.

There are influences of culture in the drama. Upon the death of her husband, her in-laws suggest the levirate custom to her (isiko lokungena). She rejects that violently. There is a lot of exaggeration in her portrayal as a rude misbehaving woman without morals because she ends up drinking liquor heavily. The author's portrayal of this character is unskilled. She is made to suffer until the end of the drama because she does not even attain her goal of marrying Lizo. This drama has type characterization.

\subsubsection{Nomhle in lintombi zinecebo}

In his drama, lintombi zinecebo, Mcimeli portrays his character Nomhle as a suffering character. She is a weak character who is abused by her brother, Mvuzo. Nomhle is not sure about who the father of her baby is. She has two boyfriends, Madoda and Vukile. Mvuzo demands payment for damages in the form of lobola from the two men. He forces Nomhle to co-operate or else face expulsion from their home. The two characters' parents died leaving them in misery and debt. Mvuzo wants to improve their condition of life by enriching himself through Nomhle's predicament and he succeeds. It is Nomhle who is left with the misery of trying to solve her problem of finding out who the father of her baby is. Nomhle's character is unreal. She is portrayed in a stereotyped manner. 
The drama is a farce. It is meant merely to cause laughter. Nevertheless that does not condone the fact that the woman protagonist Nomhle is portrayed in an unskilled manner. Her problem, which is a ludicrous improbable event, is solved in a humorous way at the end of the play. Through the help of the other characters she ultimately knows who the father of her child is. She then marries him.

There are cultural influences in her portrayal. She experiences male dominance in that she cannot oppose her brother's proposals and demands because he is a man.

\subsubsection{Nozinto in Yeha-a mfazi obulala indoda}

Nozinto in Ngewu's drama, Yeha-a mfazi obulala indoda, is married to a professional dancer, Zamile Chaneka. She is a victim of male abuse. Her husband Zamile is allegedly always away from home attending dances, but he is in love with one of the dancers and rumour has it that he will be marrying her. Nozinto reacts violently to her husband's behavior of depriving her of her rights as a married wife. The author portrays Nozinto as a murderer who kills her husband because she wants to get money from his insurance. She is portrayed as a greedy person.

One does identify cultural influences in her portrayal. No one talks badly about Zamile's behavior because men can do as they wish in a patriarchal society. When Nozinto falls in love with a certain policeman because she is deprived of her rights as a married woman, then she is criticized. She is accused of being promiscuous.

Nozinto's portrayal is not exaggerated because the author does give us flashbacks about Nozinto's problems that led to her behavior. Nozinto's problems are identified from the other characters' dialogue. Phalisa is one of those characters who give us details about Zamile and Nozinto's history of their rocky, unstable marriage. So Nozinto's actions are motivated

\subsubsection{Nolasti in linkunzi ezimbini}

Nolasti in Mothlabane's drama is portrayed as a strong character who fights for her rights. Her husband Sigqibo, who is married also to two other wives, abuses her. She is portrayed also as a troublesome character because she is always challenging Sigqibo's 
actions. Even Sigqibo's other two wives complain that ever since their husband married Nolasti, Sigqibo is always aggressive. Sigqibo does not want to be challenged by a woman. He does not want to involve Nolasti even in choosing a school for their son. Nolasti demands to be involved because the child is her son too. She is portrayed as an aggressive character who is disrespectful. According to the other characters, she is supposed to respect her husband as a head of the family. Nolasti is criticized also for making arrangements with her employer, Mrs White, to help her with babysitting on a certain night. Sigqibo feels that she should have consulted him. At one stage in their clashes, her husband physically abuses Nolasti.

Nolasti is real. She fights for her rights against all odds. It is sad that at the end of the play she does not achieve her goal. She decides to obey her husband. She seems to be defeated and thinks that she had a bad approach in fighting for her rights. The author does this deliberately thus trying to prove that there can be no two cultures in one place, hence the title of the book, linkunzi ezimbini (Two bulls.)

Cultural influences in the portrayal of Nolasti are identified. Nolasti is in a polygamous marriage. She helps her husband Sigqibo in maintaining the other two wives. She is abused by her husband physically, and decides to return to her parent's place. Without being fetched by Sigqibo she decides to go back to her umzi not only because she does not get support from her mother and brother. She feels that the other two wives are happy and do not clash with their husband because they stick to tradition. Nolasti decides to tolerate her husband's ill-treatment just like other wives. Mrs White is surprised and disappointed because she has long been thinking that Nolasti liked the idea of being a liberated woman.

\subsubsection{No-ankile in Emgxobhozweni}

No-ankile is portrayed as a greedy character who always plans bad things about other people thus hindering their progress. She is always involved in those intrigues. The author portrays her as someone who likes status and key positions. No-ankile is at loggerheads with Nomonde, her husband's daughter. They have businesses and Noankile's husband feels that No-ankile is jealous of Nomonde. No-ankile is portrayed as a woman who married her husband Vakele not for love but because she wants to inherit his businesses. Vakele does not solve the problem between No-ankile and Nomonde. He 
decides to stand by his daughter Nomonde against his wife. The author wants to portray how devious, greedy and evil No-ankile is. No-ankile is unreal. She is portrayed in a stereotyped manner.

There are cultural influences in No-ankile's portrayal. Women abuse and male dominance characterize this drama. No-ankile is not expected to challenge her husband Vakele about their home affairs because she is a woman. She is portrayed as a cruel stepmother and that is common in African culture. Stepmothers are always known to be cruel. No-ankile is expected to be obedient and respectful. When she challenges her husband she is said to be rude and greedy for his businesses. The way Vakele treats her leads to her aggressive attitude and finally to her downfall. She loses everything in the end including her business. She becomes mentally disturbed. Her portrayal is unskilled.

\subsection{PORTRAYAL OF WOMEN IN XHOSA DRAMA}

In Xhosa drama, authors delineate unreal characters. Their minds are so pre-occupied by liberation of women from the yoke of tradition expropriated in various dimensions in different historical epochs that in the process they totally forget about their characters. Their characters do things that are not done in Xhosa culture. They allow them to behave irrationally as regards customs. Stereotypical portrayal of women characters in these dramas has impacts on characterization, plot, theme and style as literary aspects.

In Xhosa drama women characters are oppressed and their character traits are conditioned by modes of representation in a patriarchal society. It is clear that the authors campaign against women's oppression and advocate women's rights. The authors not only object to the traditional roles of women, but call for equal rights for women in all social activities. Unfortunately their portrayal of women is done in a stereotypical way.

As Minas (1993:10) observes, it is a fundamental claim of feminism that women are oppressed. She further explains that the word "oppression" is a strong word. It repels and attracts. It is much misused, and sometimes innocently. The statement that women are oppressed, she observes, is frequently met with the claim that men are oppressed too. One needs to think clearly about oppression and there is much that militates against this. One shares her argument when she asserts that "we need this word, this concept and we need it to be sharp and sure". 
The root of the word "oppression" Minas (1993:10) declares is the element "press". She elaborates by saying that:

The press of the crowd, pressed into military service, to press a pair of pants, printing press, presses the button. Something pressed is something caught between or among forces and barriers which are so related to each other that jointly they restrain, restrict or prevent the thing's motion or mobility.

She further explains that men and women are always in a state of tension with respect to each other. These conflicts are due to their roles of oppressor and oppressed. Each blames the other for their respective situations.

Inene nasi isibhozo plays a big role in setting stereotypes. According to MacDonald $(1995: 20)$ the concept of stereotype is used:

To criticize the reduction of three-dimensional quality of the real to a one-dimensional and distorted form.

He explains that particularly when the group being stereotyped is already in a disadvantaged position, the stereotype intensifies the offence. He quotes Tessa Perkins (1979) who points out that stereotypes survive by undergoing change, and by convincing us that they are not entirely false, but contains a "kernel of truth". MacDonald (1995:21) asserts that like ideology, the stereotype works by being plausible and by masking its own value-system.

Gender stereotyping does have effects as illustrated in Inene nasi isibhozo. One way in which the author operated is by setting up a self-fulfilling prophecy. His women characters are viewed as having more negative characteristics than males. Women characters in Xhosa drama are portrayed to be less rational than males and they do not even solve their problems in a convincing manner. They solve their problems by killing other characters and committing suicide. One should be aware that in modern psychology, suicide is an act of aggression against the survivors.

Gender stereotypes and culture distortions by authors are powerful forces which the authors use to advocate change. The culture reflected in the images in these dramas 
frames women characters in representations which in Kuzwayo's words as quoted by Masden (1994:121) are "something truly to wonder at" when the circumstances of their lives are taken into account. The authors' thematic concerns affect the dramas' plot structures and are devised to suit the theme of women abuse and male dominance. Women characters are portrayed as capriciously cruel and weak and requiring to be kept under firm control.

\subsection{CRITICISM OF WOMEN CHARACTERS}

Many women characters in Xhosa dramas solve their problems by killing other people and even by committing suicide. MaSukude in Inene nasi isibhozo is one such character. There is no Xhosa woman who solves her problems by killing so many people. In plays of a tragic nature where momentous actions are concerned, the demands of motivation are of immense value and higher than in comedies. That is why the researcher is refusing to accept and admire a supposedly serious drama like Inene nasi isibhozo in which deathbringing actions of the woman protagonist MaSukude are inadequately motivated. Such a negligence of psychological plausibility as Kaplan (1992:76) puts it, "turns tragedy into travesty". There is just no consistency in the author's establishing of a plausible relationship between character and action.

The author demonstrates that women characters are easily abused and run away from their problems by committing suicide. They give a very poor image of women. Xhosa women are very strong: They are not submissive and they stand up for their rights. A thoughtful examination of women disproves the assumption that "women are necessarily powerless". In real life, despite male dominance of some sort or another, women are in most cases in control of themselves and their worlds. Even in folk performances genres including women's stories frequent examples of bold female voices are identified. Women are vocal and uninhibited.

The notion of the repressed and submissive Xhosa women simply does not apply to real Xhosa women. It is exaggerated in these dramas. Even if women do give in to women abuse in certain circumstances, they are articulate and they do command presence. The saying that wathint'abafazi wathint'imbokodo (you hit a woman you hit a rock) signifies their strength. In this metaphor, the word imbokodo (rock) depicts their strength. In this respect Xhosa women are NOT like the dramatic portrayals at all. Even rural women do 
have their own forms of resistance. They do not conform to the traditional ways, which symbolize subordination.

With the exception of Yeha-a mfazi obulala indoda which has very good characterization, the rest of the dramas have poor character portrayal. The reason for this weakness is attributed to several aspects such as theme and plot. The portrayal of women as being weak is surprising, because even from a religious point of view women are not easily abused. Although they are held back by the Bible teachings participating in certain duties but they silently make their voices heard concerning their rights until men feel the strain. They used not to be allowed to be pastors, but nowadays we see women being ordained as pastors.

It is not clear which type of woman the authors are portraying. Women demonstrated their strength as well in 1956 when 20,000 of them marched to the Union buildings to make their voices heard. They handed their petition to the Prime Minister.

It is encouraging that on the women's day on August 10,2000, the president of South Africa, Thabo Mbeki, unveiled a monument whose inscriptions are from the charter which was included in the women's petition of 1956. The monument includes the milling stones (imbokodo) used by women to grind mealies. The hardness of the imbokodo symbolizes women's strengths.

By examining these dramas, one is aware that despite the dramatists exaggerating obvious and true problems caused by women's oppression, in some cases the problems caused by patriarchy do exist.

It is disappointing to discover that there are still authors who write about forced marriages. This theme was predominant in the works of earlier playwrights. That is why this theme has lost its significance. Buzani kubawo (1958), ufeziwe okanye inkohlakalo (1982), Amaza (1974) and uDike noCikizwa (1963) explore this theme. The contribution of theme in the portrayal of their characters is identified. There are a lot of isolated and unmotivated incidents especially in the dramas from 1958 to 1988 . Some of these incidents are not causally related. There is a serious lack of skill as far as plot construction is concerned. Women in these dramas continue to be viewed through the prism of the domestic roles of mother, housewife and carer, not just by men, but also by women. 


\section{BIBLIOGRAPHY}

Abrahams, M.H. 1988. A Glossary of Literary terms. Japan: Holt Saunders International.

Agger, B. 1992. Western Marxism: an introduction: classical and contemporary sources. Santa Monica, California.

Amuta, C. 1989. The Theory of African Literature. Zed Books Ltd.

Aristotle, H.L. 1965. Classical Literary Criticism. London: Penguin Books.

Ayisi, E.O. 1992. An introduction to the study of African culture. East African Educational Publishers. Nairobi.

Basow, S.A. 1992. Gender stereotypes and roles. Belmont, California: Wadsworth Inc;

Berke, C. 1997. Counter culture. London: Owen.

Bennett, T.W. 1995. Human rights and African Customary Law (under the South African constitution). Cape Town, Juta \& Company.

Billing, D.Y. \& Alvesson, M. 1997. Understanding Gender and Organizations. London: Sage Publications. New Delhi: Thousand Oaks.

Bonvillian, N. 1997. Women and men; cultural constructs of gender. Englewood Cliffs, $\mathrm{NJ}$,: Prentice-Hall.

Borden, G.A. 1976. Cultural orientation: an approach to understanding intercultural communication. Englewood Clifts, N.J.: Prentice-Hall.

Boulton, M. 1980. The Anatomy of Drama. London: Routledge and Kegan Paul.

Brooke, P. 1995. Communicating through story characters. Radio drama. New York, London: University Press of America. 
Brooks, C. \& Heilman, R.B. 1964. Understanding Drama. New York: Rinehart \& Winston.

Cohen, B.B. 1973. Writing about Literature. Glenview: Scott Foresman and Company.

Casson, W. 1981. Language culture and cognition: anthropological perspectives. New York: MacMillan.

Conradie, P.J. 1978. Spanning en ewewig. Pretoria/Kaapstad: Academia.

Dancyger, K. 1990. Broadcasting Writing: Drama, Comedies and Documentaries. Boston: Focal Press.

Darby, P. 1997. At the edge of international relations: postcolonialism, gender and dependency. London: Sage

Davis, R.C. and Schleifer, R. 1991. Criticism and culture: the role of critique in modern literary theory. Essex: Longman Group UK Limited.

Davis, S.M. 1970. Farce. Cambridge, MassiBalinger.

Daymond, E.R. 1996. South African feminisms: writing, theory and criticism, 1990-1994. New York: NY: Garland.

Dowling, D.S. 1997. Subversive narrative and thematic strategies: A critial appraisal of Fay Weldon's fiction. Pretoria: University of South Africa.

Esslin, M. 1976. An Anatomy of Drama. London: Sphere books.

Featherstone, M. 1990. Global culture. London: Sage.

Fiske, J. 1989. Understanding Popular Culture. London: Unwin Hyman.

Fowler, H.W. \& Fowler, F.G. 1995. The Concise Oxford Dictionary of Current English. Glasgow: Clarendon Press. 
Friedman, R.C. 1989. Masculinity and sexuality: selected topics in the psychology of men. London and New York: Routledge.

Geertz, C. 1973. Myth, Symbol and Culture. New York NY: Norton.

Gerard, A.S. 1980. African Language Literatures. An introduction to the Literary History of Sub-Sahavan Africa. Essex: Longman.

Gherardi, S. 1995. Gender, symbolism and organizational cultures. London: Sage.

Goodenough, P.W. 1981. Culture, language and society. Menlo Park, California: Benjamin-Cummings.

Goodman, L. 1993. Contemporary Feminist Theatres. London \& New York: Routledge.

Grey, S. 1984. Modern Stage Directions. Cape Town: Maskew Miller, Longman.

Hawthorn, J. 1985. Unlocking the text: fundamental issues in literary theory. London: Arnold.

Heese, M. \& Lawton, R. 1988. The New Owl critic. An introduction to Literary Criticism. Goodwood: Nasional Book Printers.

Hofstede, G. 1984. Culture's consequences: International differences in work-related values. Beverley Hills, C.A. : Sage Publications.

Honigmann, J. 1954. Culture and personality. New York: Harper.

Hooks, B. 1984. Feminist theory: from margin to center. Boston Mas. South End.

Jafta, D.N. 1978. A survey of Xhosa Drama. MA Thesis, University of Zululand, KwaNdlangezwa.

Jafta, D.N. 1996. Tragic expressions in selected Xhosa literary works. Unpublished Ph.D. thesis. University of Stellenbosch, Stellenbosch. 
Jongilanga, D.M. 1973. Ubusuku obungenanyanga. Cape Town: Via Afrika.

Kaplan, M. 1992. Imagining women: cultural representations and gender. Cambridge, England: Polity.

Keuris, M. 1996. The Play. Pretoria: JL van Schaik Academic.

Koyana, D.S. 1980. Customary Law in a changing society. Juta Publishers.

Kroeber, A.L. \& Kluckhohn. 1952. Culture: a critical review of concepts and definitions. Cambridge: M.A. Harvard University.

Mabley, E. 1972. Dramatic Construction: An Outline of Basic Principles. New York: Chilton Book Company.

MacDonald, M. 1995. Representing women. Myths of femininity in the popular media. London, New York.

Madadzhe, R.N. 1985. N.A. Milubi's drama: A critical appraisal of dramatic criteria. A dissertation submitted to satisfy the requirements for the degree of Master of Arts in the Department of Venda, In the Faculty of Arts, University of the North.

Makosana, N.E. 1991. A comparative study of six Xhosa Radio Drama. Unpubllished MA Dissertation, University of Stellenbosch.

Marsden, D.F. 1994. Changing images: Representations of South African Black Women in works by Bessie Head, Ellen Khuzwayo, Mandle Langa and Mongane Wally Serote. M.A. Thesis. Pretoria: University of South Africa.

Mcimeli, R.F. 1992. lintombi zinecebo. De Jager and Haum.

Mead, M. 1960. Mind, self and society, from the standpoint of a social behaviorist. Chicago: University of Chicago Press. 
Minas, A. 1993. Gender Basics. Feminist perspectives on women and men. Wadswork, California.

Mkonto, B.B. 1988. Emgxobhozweni. Cape Town: Vivlia Publishers and Booksellers.

Mmango, A. 1963. UDike noCikizwa. Johannesburg: Educum.

Mothlabane, H. 1994. linkunzi ezimbini. Pietermaritzburg: Centaur.

Mtingane, A. 1965. Inene nasi isibhozo. Cape Town: Oxford University Press.

Mtywaku, D.T. 1982. UFeziwe okanye inkohlakalo. Pretoria: Van Schaik.

Muhanganei, T.P. 1999. The role of women in M.J. Netshivhuyu and N.A. Milubi's dramas. A dissertation submitted in fulfillment of the requirements for the degree of Master of Arts. Faculty of Arts. University of the North.

Mulder, N. 1977. Inside South East Asia: religion everday life, cultural change. Amsterdam: Pepin Press.

Ngewu, L.L. 1997. Yeha mfazi obulala indoda. Pretoria: Van Schaik.

Ngozi, E.M. 1994. Some of us are brave: A configuration of Revolutinary Black Women Dramatists (Nigeria, South Africa and the United States), Umi Dissertation Services. A Bell and Howell Company.

Nnaemeka, O. 1988. Sisterhood, Feminisms and Power: From Africa to the diaspora. Trenton: Africa World Press, Inc.

Ntshinga, T. 1995. Conference at the UNISA Centre for Women's studies. Gender in Xhosa proverbs: Women's New Expressions of Emancipatory Concerns. Pretoria: University of South Africa.

Ogude, J. 1999. Ngugi's novels and African history: narrating the nation. London: Pluto. 
Perrin, L. 1988. Literature: structure, sound and sense. Fort Worth: Brace Tavannocich College Publishers.

Pickering, J.H. 1981. Concise Companion to Literature. $1^{\text {st }}$ Edition. New York: MacMillan.

Prince, G. 1982. Narratology: the form and function of narrative. The Hague: Mouton.

Qangule, Z.S. 1974. Amaza. King Williamstown: Educum Publishers, Thanda Press.

Rae, K.A. 1971. Dialogue and characterization in the plays of Athol Fugard. Dissertation submitted in fulfilment of the requirements for the degree of Magister Dramatologice. University of Pretoria, Pretoria.

Roberts, E.V. 1992. Writing themes about literature. London, New York: Prentice Hall.

Shroyer, F.B. 1970. Types of drama. Glenview, III: Scott, Foresman.

Sirayi, G.T. 1993. The characteristics of some Xhosa dramas. Thesis submitted in fulfillment of the requirements for the degree of Master of Arts. Rhodes University, Grahamstown.

Smiley, S. 1971. Playwriting: the structure of action. New Jersey: Prentice-Hall, Inc.

Soga, J.H. 1933. The AmaXosa: Life and customs. Alice: Lovedale Press.

Storey, J. 1993. An introductory guide to cultural theory and popular culture. Hertfordshire: Simon and Schuster International Group.

Tamsanqa, W.K. 1958. Buzani kubawo. Cape Town: Oxford University Press.

Taylor, H.M. 1999. Gendered missions: women and men in missionary discourse and practice. Ann Arbor, Mich, University of Michigan Press.

Toliver, H.E. 1969. Perspective on poetry. New York: Oxford University Press. 
Tshikovhi, V.R. 1997. Tragedy in N.A. Milubi's drama. Unpublished MA dissertation, University of the North.

Van der Vyver, F.J.R. \& Hutschemaekers.G.J.M. 1990. The investigation of culture. Current Issues in Cultural Psychology. Tilburg University Press.

Van Tromp, J. 1947. Xhosa Law of Persons. A treatise on the legal principles of family relations among AmaXhosa. Cape Town and Johannesburg; Juta \& Company. Wheatheaf, M. 1994. Cultural conceptualisation. Tilburg: Tilburg University Press.

Williams, P. 1976. Toward the idea of a cultural psychology. Beverley Hills, CA: Sage.

Zulu, N.S. 1998. Characterisation in selected Sesotho novels. Unpublished D.Litt. Dissertation, University of Stellenbosch. 